REGINA VITORIA SOARES GARCIA

\title{
A TRIBUTAÇÃO DO ISS NA SOCIEDADE DA INFORMAÇÃO
}

\author{
Dissertação de Mestrado \\ Orientador: \\ PROFESSOR DOUTOR PAULO AYRES BARRETO
}

Faculdade de Direito da Universidade de São Paulo (FDUSP)

São Paulo - SP 


\title{
A TRIBUTAÇÃO DO ISS NA SOCIEDADE DA INFORMAÇÃO
}

\author{
Mestrado em Direito Econômico e Financeiro
}

Dissertação apresentada à Banca Examinadora da Faculdade de Direito da Universidade de São Paulo, como exigência parcial para obtenção do título de MESTRE em Direito Econômico e Financeiro, sob a orientação do Professor Doutor Paulo Ayres Barreto.

Faculdade de Direito da Universidade de São Paulo (FDUSP)

São Paulo - SP 
Autorizo a reprodução e divulgação total ou parcial deste trabalho, por qualquer meio convencional ou eletrônico, para fins de estudo e pesquisa, desde que citada a fonte.

Garcia, Regina Vitoria Soares.

A Tributação do ISS na Sociedade da Informação/ Regina Vitoria Soares Garcia.

- São Paulo : R. V. S. Garcia, 2013.

$321 \mathrm{f} . ; 30 \mathrm{~cm}$.

Dissertação (Mestrado) - Universidade de São Paulo, 2013.

Orientador: Prof. Doutor Paulo Ayres Barreto.

Notas de rodapé.

Inclui bibliografia.

1. Tributação. 2. Imposto sobre Serviços de Qualquer Natureza. 3. Comércio Eletrônico. 4. Internet. 5. Aspecto Material e Aspecto Espacial da Regra-matriz de Incidência. 6. Estabelecimento permanente e estabelecimento prestador de serviço. 
Nome: GARCIA, Regina Vitoria Soares.

Título: A Tributação do ISS na Sociedade da Informação

Dissertação apresentada à Faculdade de Direito da Universidade de São Paulo (FDUSP) para obtenção do título de Mestre em Direito Econômico e Financeiro.

Aprovado em:

BANCA EXAMINADORA:

Prof. Doutor Associado Paulo Ayres Barreto (orientador) Instituição: FDUSP

Julgamento:

Assinatura:

Prof. Doutor

Instituição:

Julgamento:

Assinatura:

Prof. Doutor

Instituição:

Julgamento:

Assinatura: 
Ao meu orientador Professor Paulo Ayres Barreto, pelos inestimáveis conselhos, pela sabedoria na orientação precisa e, principalmente, pela confiança, fundamentais para alcançar o resultado deste trabalho.

Ao mestre Paulo de Barros Carvalho, pela confiança depositada.

Ao Osvaldo, companheiro de todas as horas, que compartilhou comigo as alegrias e angústias deste caminho, pelo carinho, apoio e renúncia aos finais de semana.

À família, pela compreensão.

À Nina, amor incondicional, dedico este trabalho. 


\section{RESUMO}

O presente trabalho tem por finalidade estudar e identificar as perturbações sobrevindas nos critérios material e espacial da regra-matriz de incidência do Imposto sobre Serviços, decorrentes da alteração estrutural resultante da incorporação das novas tecnologias da informação e da comunicação (TICs) nas transações do comércio eletrônico. Os recursos telemáticos não apenas despojaram as transações comerciais do contato físico entre os sujeitos envolvidos, mas relativizaram as condições de tempo e espaço, inerentes a todos os fatos jurídicos.

Assim, buscamos examinar simultaneamente, de maneira análoga, a problemática da tributação do comércio eletrônico nos Estados, por meio do Direito Internacional Tributário, e a realidade vivida pelos Municípios no direito interno relativamente à tributação dos serviços afetados pelas mesmas inovações tecnológicas. Para tanto, o estudo foi pautado na definição de elementos de conexão, revelados em conceitos como "estabelecimento permanente" e "estabelecimento prestador", para a delimitação da competência impositiva relativa aos fatos jurídicos inerentes às transações eletrônicas.

O estudo se inicia na definição dos problemas jurídico-tributários inerentes ao comércio eletrônico, fixando seu conceito e analisando suas espécies e características específicas, adentrando no estudo do regime jurídico dos bens digitais, objeto das transações do comércio eletrônico direto.

Ainda em estudo preliminar, abordamos aspectos relativos à Federação brasileira, definindo a realidade dos Municípios e analisando seu papel na Federação brasileira, divisando a composição de suas rendas próprias e a participação efetiva e potencial da receita tributária. Esta análise será concomitante àquela da outorga de competência impositiva no Brasil, e no direito comparado, finalizando por revisitar os temas da partição da competência dos tributos incidentes sobre o consumo e da dicotomia "tipo-conceito".

Por fim, após a análise destas questões preliminares, e munidos de um adequado suporte teórico, adentramos no estudo específico do Imposto sobre Serviços e da nova realidade na prestação de serviço advinda da reestruturação das empresas, da redistribuição das etapas de trabalho e da relativização da presença física nas relações 
comerciais, analisando as alterações nos conceitos de "serviço" e "estabelecimento prestador" na definição das competências impositivas dos Municípios.

Ao final, será verificada a possibilidade da aplicação das soluções utilizadas no direito internacional e propostas pela doutrina para a concreção do conceito de "estabelecimento permanente", aplicadas àquele de "estabelecimento prestador" no direito interno, em especial à configuração de servidores de dados e sites web como estabelecimento. Em conclusão, após a proposição de definição para os critérios material e espacial das transações no comércio eletrônico, dedicamos um breve estudo da aplicação prática dos mecanismos propostos a alguns serviços que sofreram alterações pela incorporação dos meios virtuais. 


\begin{abstract}
This study aims to analyze and identify disturbances that appear on the material and spatial criteria of incidence matrix-rule model of the Service Tax, arising from structural change resulting from the incorporation of new information and communication technologies (ICTs) in electronic trade transactions. The telematic resources not only deprived the business transactions of physical contact between the individuals involved, but relativized conditions of time and space inherent in all legal facts.

Therefore, we sought to examine simultaneously, in a similar way, the issue of taxation of electronic commerce in the Brazilian States, through the International Tax Law, and the reality experienced by Municipalities in the law regarding the taxation of services affected by the same technological innovations. Thus, the study was guided by the definition of connecting factors, revealed in concepts such as "permanent establishment" and "establishment rendering" to delimit the jurisdiction imposing on legal facts inherent to electronic transactions.

The study begins with the definition of legal and tax issues relating to electronic commerce, establishing its concept and analyzing its specific types and characteristics, studying the legal regime of digital assets, object of direct e-commerce transactions.

Still in the preliminary study, we address aspects of the Brazilian Federation, defining the reality of Municipalities and analyzing their role in the Brazilian Federation, devising the composition of their own incomes and effective participation and potential tax revenue. This analysis is concomitant to that of grant of jurisdiction imposing in Brazil, and in comparative law, ending by revisiting the themes of partition within the competence of taxes on consumption and the dichotomy "type-concept."

Finally, after a preliminary analysis of these issues and based on an adequate theoretical support, we studied the specific Services Tax and the new reality in the provision of services arising from the restructuring of the companies, the redistribution of work steps, and the relativization of physical presence in trade relations, analyzing the changes in the concepts of "service" and "establishment rendering" in the definition of the powers of Municipalities.
\end{abstract}


At the end, we will be investigating the possibility of applying the solutions used in the international law and doctrine proposals for the concretion of the concept of "permanent establishment", applied to that of "establishment rendering" under domestic law, in particular the configuration of data servers and websites like setting. In conclusion, after the proposal of setting criteria for material and spatial transactions in ecommerce, we dedicate a brief study of the practical application of the proposed mechanisms to some services that were modified by the incorporation of virtual media. 


\section{SUMÁRIO}

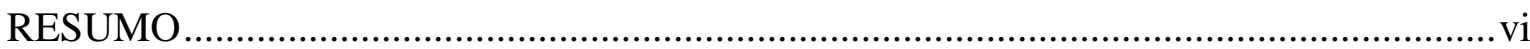

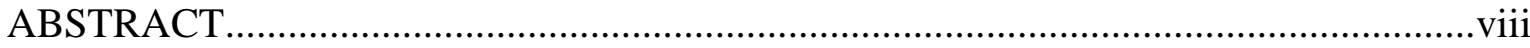

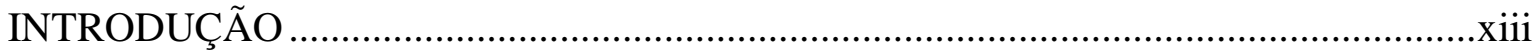

1. CONSIDERAÇÕES PROPEDÊUTICAS GERAIS ........................................... 18

1.1. Serviços: Evolução e Relevância Econômica......................................................... 18

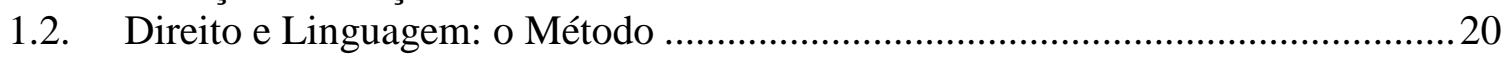

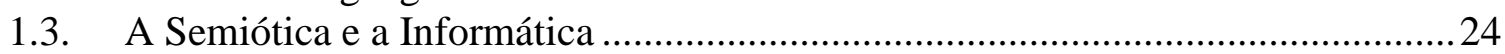

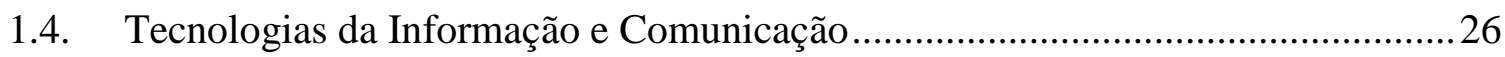

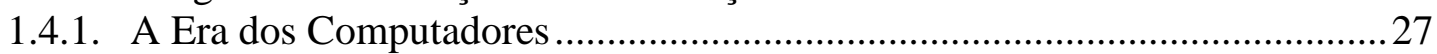

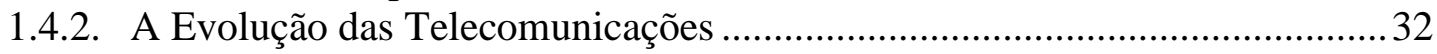

1.4.3. Computadores Pessoais: evolução tecnológica ou revolução social? ..............36

1.4.4. Internet: a Grande Rede Mundial ...........................................................40

2. OS PROBLEMAS JURÍDICO-TRIBUTÁRIOS NO COMÉRCIO ELETRÔNICO

46

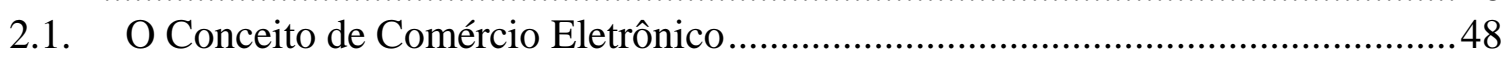

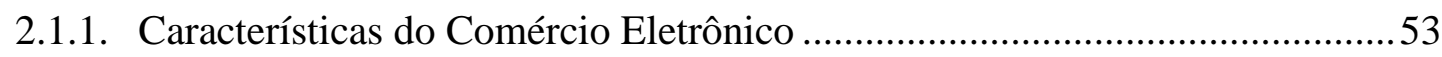

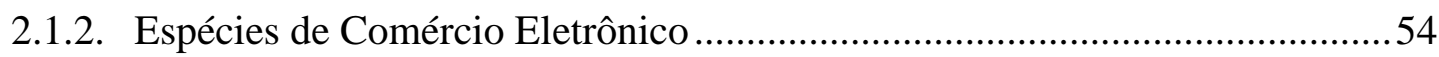

2.2. Comércio Eletrônico no Brasil - Dados Estatísticos .............................................55

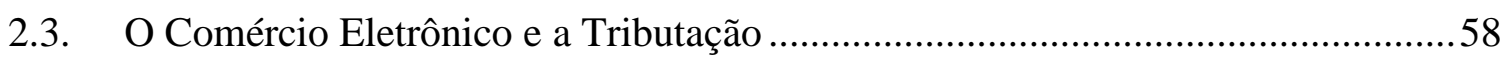

2.4. Comércio Eletrônico Direto: os Bens Digitais ......................................................59

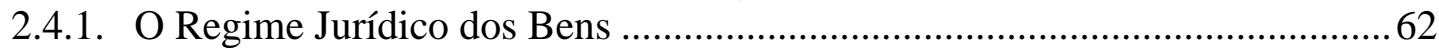

2.4.1.1. O Regime Jurídico aplicável aos Bens Digitais ...................................67

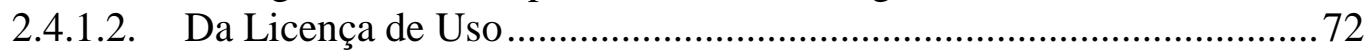

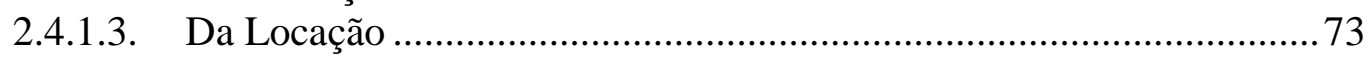

2.4.1.4. Da Cessão de Direitos................................................................. 74

2.4.2. Cloud Computing: a virtualização do cenário tecnológico.............................. 77

2.4.2.1. Cloud Computing: novas categorias de "serviços"? .......................... 82

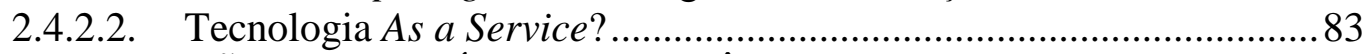

3. A TRIBUTAÇÃO DO COMÉRCIO ELETRÔNICO INTERNACIONAL ............88

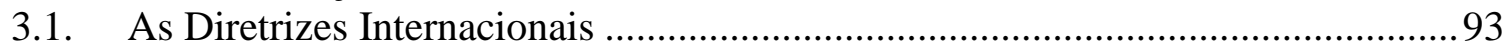

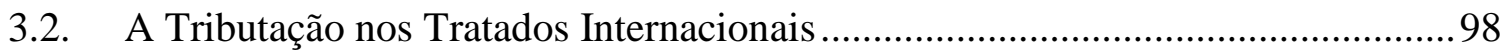

3.3. A Qualificação da Renda do Comércio Eletrônico.............................................. 102

3.4. A Determinação da Fonte e da Residência no E-commerce .................................. 104

3.5. O Comércio Eletrônico na Convenção Modelo da OCDE .................................... 106

3.5.1. Comentários à CM-OCDE: Servidor de Dados............................................ 107

3.5.2. Comentários à CM-OCDE relativos à Prestação de Serviços ........................ 111

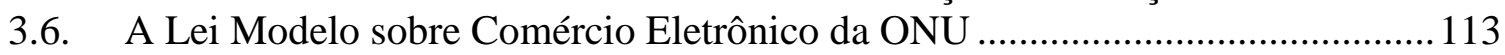

3.7. O Comércio Eletrônico no MERCOSUL ............................................................ 114

3.8. O conceito de "Estabelecimento Permanente" no Direito Internacional Tributário

3.8.1. O "Estabelecimento Permanente Físico" - Servidor de Dados ..................... 122

3.8.2. A Permanência da Instalação: Elemento Temporal e Espacial ..................... 124

3.8.3. O Teste da Atividade Econômica (Business Activity Test)........................... 125

3.8.4. O Agente como Estabelecimento Permanente.............................................. 128

3.9. Propostas para a Tributação do Comércio Eletrônico ......................................... 130 
4. COMPETÊNCIA TRIBUTÁRIA: OS MUNICÍPIOS NA FEDERAÇÃO

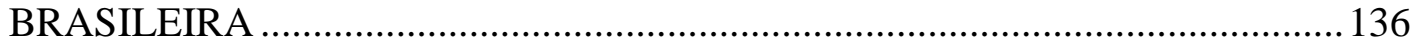

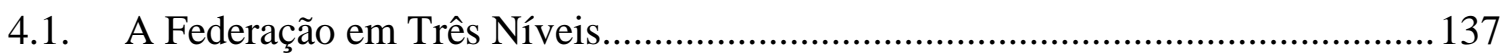

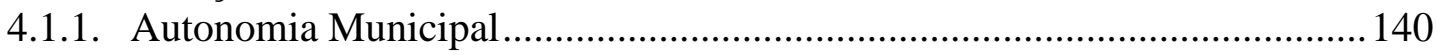

4.1.2. O Município na Federação perante as Constituições Brasileiras .................. 141

4.1.3. Autonomia Municipal: Limites ................................................................. 144

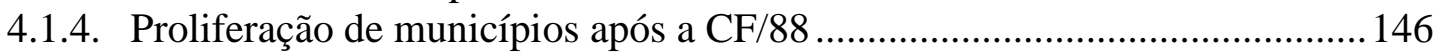

4.1.5. Os Municípios no atual cenário brasileiro .............................................. 147

4.1.6. Autonomia e Receita Tributária própria: análise de caso ............................ 149

4.2. Competência Tributária: Conceito e Acepção .................................................... 154

4.2.1. O Sistema Tributário: Delimitação das Competências.................................. 156

4.2.2. A discriminação das competências e a classificação dos tributos .................159

4.2.3. Repartição de competências no direito comparado ...................................... 162

4.2.4. A Repartição dos Tributos sobre o Consumo na Federação Brasileira: a

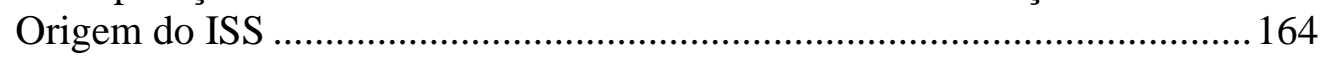

4.2.5. Constituição Federal: Tipos ou Conceitos? ............................................... 171

5. O COMÉRCIO ELETRÔNICO E O IMPOSTO SOBRE SERVIÇOS DE QUALQUER NATUREZA ........................................................................... 181

5.1. A Regra-Matriz de Incidência do Imposto sobre Serviços de Qualquer Natureza

.................................................................................................................... 182

5.1.1. As Funções da Lei Complementar e a Lista de Serviços ............................... 183

5.2. O Critério Material do Imposto sobre Serviços de Qualquer Natureza................188

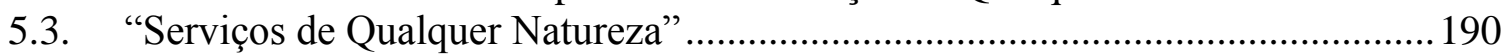

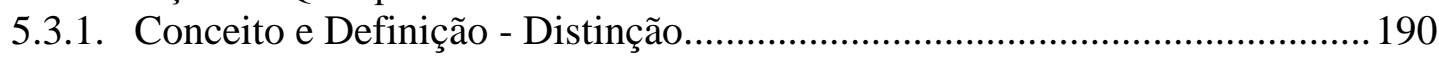

5.3.1.1. Os Propósitos da Definiçãa ............................................................ 193

5.3.1.2. Definições Denotativas e Conotativas .............................................. 195

5.3.1.3. "Significado de Base" das Palavras ................................................... 196

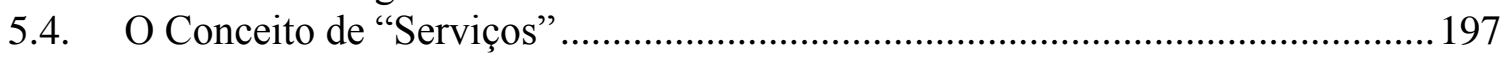

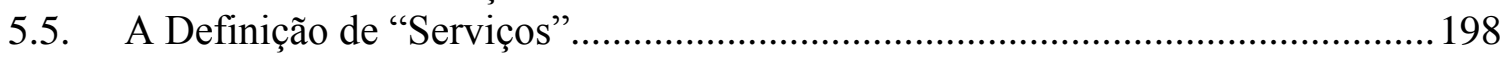

5.6. A Revisão do Conceito de "Serviço" no STF: "Serviços de Qualquer Natureza"

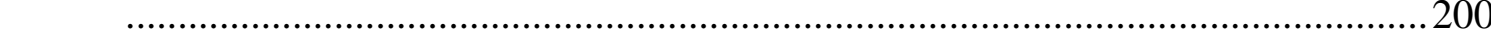

5.7. Os Conceitos Constitucionais perante o Supremo Tribunal Federal ....................204

5.8. Construção de sentido a partir de conceitos constitucionais e as novas realidades

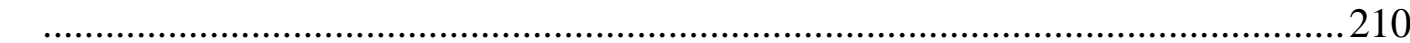

5.8.1. Mercadoria x Mercadoria Virtual ............................................................2 213

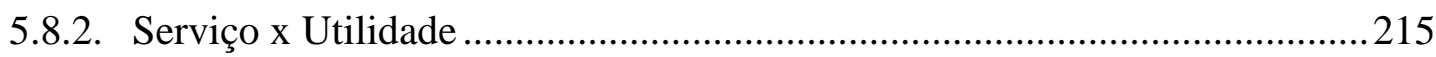

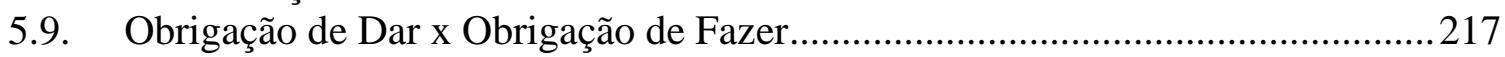

5.10. Conceito de "Serviço" na Legislação Infraconstitucional ....................................220

5.11. O critério Espacial do Imposto Sobre Serviços de Qualquer Natureza ...............221

5.12. A Definição do Aspecto Espacial - Critérios Legais .........................................222

5.12.1. Âmbito de Incidência x Âmbito de Validade da Norma ...............................224

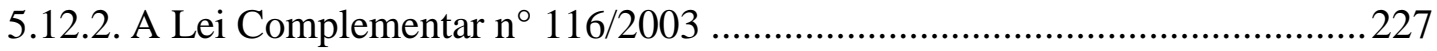

5.12.3. O Estabelecimento Prestador ..................................................................2230

5.13. Elementos de Conexão, a Constituição Federal e a LC n ${ }^{\circ} 116 / 2003$..................2233

5.14. Os Conceitos Operacionais de "Desenvolvimento do Serviço" e "Verificação de

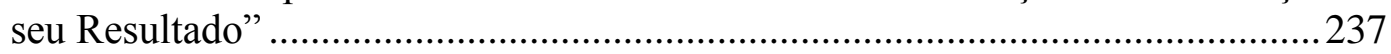

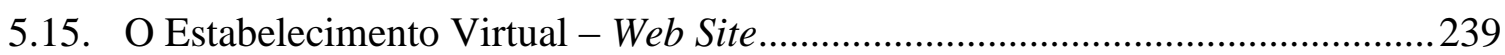

5.16. Critério doutrinário: Atividade-Meio e Atividade-Fim .....................................2 242

5.17. A Jurisprudência relativa ao Critério Espacial após a LC n ${ }^{\circ} 116 / 2003$...............244

6. DA TRIBUTAÇÃO DO COMÉRCIO ELETRÔNICO NO BRASIL ......................248 
6.1. As Primeiras Diretrizes: a Tributação do Software .............................................251

6.1.1. Imposto sobre o Consumo: a Origem e o Destino no Comércio Eletrônico 256

6.2. A Regulamentação do ICMS Incidente no Comércio Eletrônico.........................258

6.3. Da Tributação do Consumo no Comércio Eletrônico.........................................263

6.4. O Comércio Eletrônico Indireto ......................................................................265

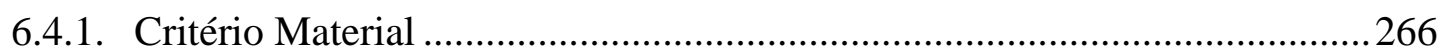

6.4.1.1. Da "Circulação de Mercadorias" ...................................................267

6.4.1.2. Da Prestação de Serviços ..............................................................268

6.4.2. Critério Espacial do Imposto sobre Serviços.............................................268

6.4.2.1. Coexistência de Locais .................................................................2269

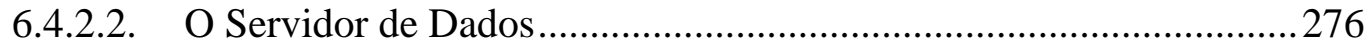

6.4.2.3. Inexistência de Estabelecimento Físico - Web Site ..........................2277

6.5. O Comércio Eletrônico Direto............................................................................2 279

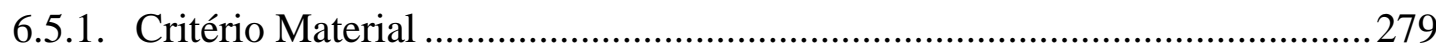

6.5.1.1. "Prestação Eletrônica de Serviços" .............................................2279

6.5.1.2. Fornecimento de Bens Digitais ...................................................228

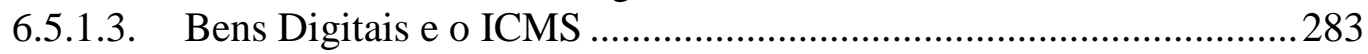

6.5.1.4. Bens Digitais e o ISS ....................................................................286

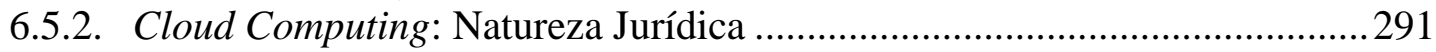

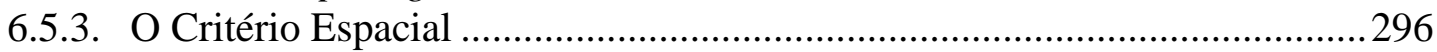

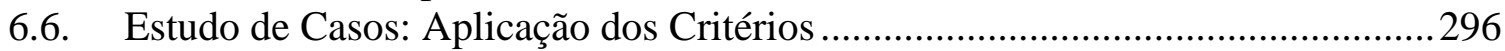

6.6.1. Monitoração Eletrônica de Pessoas ..........................................................297

6.6.1.1. Laboratórios de Análises Clínicas: análise à distância

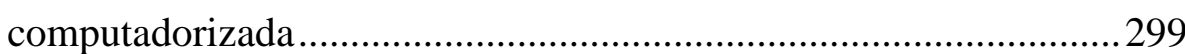

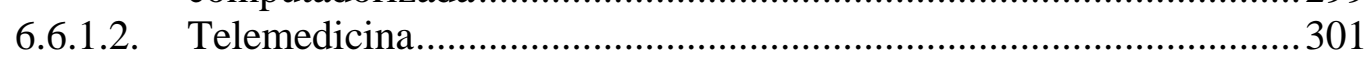

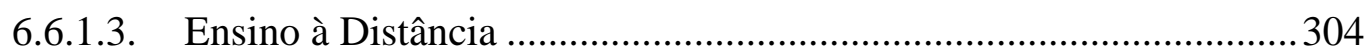

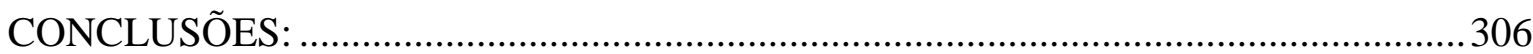

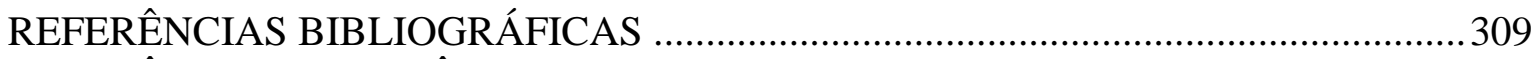

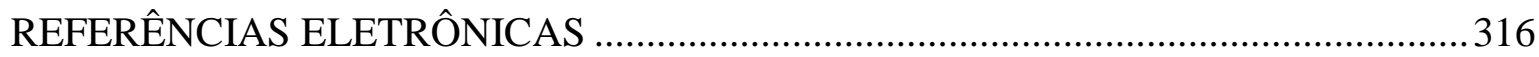




\section{INTRODUÇÃO}

No final do século passado, o mundo foi surpreendido com profundas e rápidas evoluções na área social e comercial, resultado de um crescente e intenso progresso tecnológico nunca experimentado na história da civilização. O desenvolvimento estratégico das tecnologias da informação e da comunicação repercutiu por toda a estrutura social, comercial e cultural. As riquezas passaram a ser criadas não apenas com base em bens materiais, mas também na mente ou no conhecimento, sobrepondo-se a riqueza imaterial àquela tradicional, que tinha preferência pela propriedade da terra, do bem imóvel. Surge uma "Nova Economia" em que até mesmo a moeda assume a forma eletrônica, transferindo-se pelo mundo e sendo monitorada em telas de computador. ${ }^{1}$

As plataformas de tecnologia da informação (TI) das empresas suportam os fluxos de comunicação em tempo real, permitindo-lhes criar equipes virtuais que compartilham seus melhores profissionais, independentemente de sua localização física, alocando as funções conforme seus custos em países com diferentes perfis. Assim, buscando a melhor forma de organização, a eficiência da gestão financeira e a especialização, a produção concentra-se em países cuja mão-de-obra tem baixo custo, a distribuição estabelece-se naqueles em que são praticados baixos impostos, e a pesquisa e desenvolvimento alocados em um país que concede subsídios. ${ }^{2}$

A complexidade desta nova forma organizacional das empresas e especialmente sua apatridia desafiam e revitalizam discussões sobre conceitos como "local da residência", "fonte de produção" e "estabelecimento permanente", normalmente utilizados para determinar o direito subjetivo de tributar rendas entre países, e hoje estudados pelas autoridades fiscais para desestimular grupos especializados em planejamento fiscal. $^{3}$

Neste cenário, especialmente na área tributária, a realidade caminha em velocidade exponencialmente superior àquela dos ordenamentos jurídicos, exigindo dos

\footnotetext{
${ }^{1}$ Cf. PINHO, Diva Benevides, Aspectos da Evolução da Ciência Econômica - da Economia da Informação às raízes do pensamento econômico, in Manual de Economia, org. PINHO, Diva Benevides e VASCONCELOS, Marco Antonio, $5^{\mathrm{a}}$ ed., São Paulo, Saraiva, pp. 42-43.

2 Cf. GAZZO, Massimiliano, Permanent Establishment Through Related Corporations, Bulletin for International Taxation. IBFD, Junho/2003, p. 257.

${ }^{3}$ Cf. Idem, ibidem, p. 257.
} 
juristas a busca de soluções entre as normas existentes para os novos conflitos e situações que surgem e não foram contemplados pelo legislador. ${ }^{4}$

Neste contexto, a Organização para o Comércio e Desenvolvimento Econômico - OCDE vê-se às voltas com milhares de acordos contra bitributação elaborados com base em conceitos que têm se demonstrado ultrapassados. Retomou-se a discussão em torno do princípio de quem deve tributar - a sede da empresa ou o local onde está o ponto de venda da empresa, a residência do consumidor ou o local onde ocorreu o consumo, o local onde o software é escrito ou onde está o servidor de dados que lhe serve de alojamento, o local do estabelecimento dos consultores ou a sede da empresa que os contrata.

O comércio eletrônico ${ }^{5}$ ameaça princípios tradicionais, como o Princípio de Única Tributação e o Princípio do Benefício, que coloca em discussão o conceito de "estabelecimento permanente", cujo pressuposto é, entre outros requisitos, a existência física do mesmo ${ }^{6}$, levando a OCDE a repensar o conceito, já que com a tecnologia a presença física tornou-se irrelevante em muitos casos. ${ }^{7} \mathrm{E}$ os pressupostos que conformam o princípio da territorialidade, representados pelos aspectos materiais das situações tributáveis, como o local da situação dos bens, o local do exercício de uma atividade e o local do estabelecimento permanente, passam por uma "sucessiva desmaterialização", motivo pelo qual deveria ser superada a visão clássica do referido princípio. ${ }^{8}$

Buscando soluções para as novas realidades, permitiremo-nos cotejar a situação internacional com aquela havida entre os entes da Federação brasileira, vislumbrando fenômeno semelhante, guardadas as devidas proporções, na tributação do consumo interno. Transpondo a problemática internacional para o cenário interno, na fixação de conceitos jurídicos como "estabelecimento prestador" para delinear os contornos de suas competências impositivas em termos territoriais, gerando guerra fiscal

${ }^{4}$ Cf. Apresentação in Internet - O Direito na Era Virtual. SCHOUERI, Luis Eduardo, organizador. $2^{\mathrm{a}}$. ed. Rio de Janeiro: Forense, 2001, p. 7.

${ }^{5}$ Cf. SCHOUERI, Luis Eduardo adverte em seu estudo que a utilização da expressão "comércio eletrônico" abrange "todos os casos em que os meios eletrônicos nada mais são que instrumentos de comunicação para a concretização de transações tradicionais (quando se reproduzem, embora com novas fórmulas, modelos jurídicos do comércio já existente) quanto daqueles em que, por meio da Internet, ocorre a própria cessão de bens (como os serviços ou os direitos autoriais.” (g.n.). In Internet - O Direito na Era Virtual. SCHOUERI, Luis Eduardo, organizador. 2a . ed. Rio de Janeiro: Forense, 2001, p. 39.

${ }^{6}$ Art. $5^{\circ}$ da Convenção Modelo da OCDE, In <http://www.oecd.org/dataoecd/14/32/41147804.pdf>. Acesso em 24 de abril de 2010.

${ }^{7}$ Cf. SCHOUERI, Luis Eduardo, Tributação e Cooperação Internacional in Revista Fórum de Direito Tributário, nº 7, Belo Horizonte, Fórum, 2004, p. 52.

${ }^{8}$ Cf. XAVIER, Alberto, Direito Tributário Internacional do Brasil, Rio de Janeiro, Forense, 2002, p. 24. 
entre os municípios, ou na exigência de suporte físico para alterar a natureza jurídica e, consequentemente, a tributação do software. Da mesma forma seria possível estendermos o sentido e as consequências jurídico-tributárias da globalização dos Estados ao fenômeno da metropolização e conurbação das cidades.

No momento em que se firma a jurisprudência do Superior Tribunal de Justiça relativa ao critério espacial da regra-matriz de incidência do Imposto sobre Serviços - ISS e à Lei Complementar no 116/03 9 , baseada no conceito de "unidade econômica", assim como nas relações internacionais, as transformações internas protagonizadas pelo advento da informática e as novas tecnologias repercutem nas relações sociais, econômicas e jurídicas como um todo, ${ }^{10}$ experimentando hoje os contribuintes serviços prestados em "ambientes virtuais", outros prestados em duas ou mais localidades simultaneamente e, ainda, serviços prestados à distância.

Com o fenômeno da Internet e das transações eletrônicas, as fronteiras entre os Estados passaram a ter caráter meramente geográfico, afetando e mitigando a soberania de cada um deles, em favor de organismos internacionais que visam a gerir as novas relações econômicas no mundo. $\mathrm{Na}$ área tributária, as discussões havidas entre os organismos especializados e as experiências relativas a tais transformações e às suas implicações concentram-se especialmente no aspecto espacial da regra-matriz dos tributos, tendo como escopo definir a qual Estado cabe o direito subjetivo de tributar determinados fatos jurídicos. Pretende-se então estudar a viabilidade da adoção e a transposição destas experiências e estudos do Direito Internacional para a problemática dos entes brasileiros relativas ao aspecto espacial da norma tributária referente ao ISS.

Ou seja, devido à interdependência econômica que há hoje entre os entes da Federação (de maneira símile àquela havida entre os Estados no mundo globalizado), os Municípios necessitam adotar políticas tributárias adequadas visando à preservação de suas bases tributárias, assim como a competitividade entre as empresas, atraindo seus investimentos sem descurar, contudo, dos direitos fundamentais de seus contribuintes.

9 "De acordo com os artigos $3^{\circ}$ e $4^{\circ}$ da Lei Complementar $n^{\circ} 116 / 03$, conclui-se que a municipalidade competente para realizar a cobrança do ISS é a do local do estabelecimento definindo-a como o "local do estabelecimento prestador dos serviços, considerando-se como tal a localidade em que há uma unidade econômica ou profissional, isto é, onde a atividade é desenvolvida, independentemente de sua denominação". Trecho do Acórdão do RE no 1.195.844, relator Min. Mauro Campbell Marques. Disponível em <http://www.stj.jus.br/SCON/pesquisar.jsp>. Acesso em 16 de fevereiro de 2011.

${ }^{10}$ Autores da área rechaçam a utilização da expressão impacto para designar tais alterações, acreditando que o termo levaria a uma comparação da tecnologia com um projétil (pedra, obus, míssil?) e a cultura e a sociedade como um alvo vivo. Cf. LUCCA, Newton, Direito \& Internet, Quartier Latin, 2a . ed., p. 39. 
A situação entre os municípios brasileiros é análoga àquela havida entre os Estados, que os levam em uma busca constante de definição de políticas antielisivas e legislações mais coercitivas, que desincentivem a prática da evasão fiscal, a existência de "paraísos fiscais" e lhes garanta o direito subjetivo de tributar. Discussões deste jaez têm se intensificado, requisitando do cientista do direito que se debruce sobre cada um destes negócios jurídicos, esmiuçando as relações ali contidas e seus aspectos subjacentes, de modo que haja a perfeita subsunção do fato jurídico à norma de competência, em todos os seus aspectos.

A importância do estudo dos tributos incidentes sobre o setor de serviços se fundamenta não apenas na preponderância de suas receitas na formação do Produto Interno Bruto brasileiro e no fato de abranger quase 800 mil empresas ${ }^{11}$, mas, sobretudo, por constituir o Imposto sobre Serviços - ISS a mais importante fonte de receita derivada para mais de 5.500 municípios.

Neste cenário, o atual estudo investiga a conformidade das normas adotadas pelos Estados e diretrizes firmadas pelos organismos internacionais para tratados de bitributação, assim como o direito positivo, os estudos da doutrina, em especial aqueles que definem critérios e elementos de conexão para a delimitação da competência tributária no comércio eletrônico, com a situação vivenciada pelos Municípios brasileiros na tributação dos serviços.

Destarte, o objeto específico do presente estudo é o critério espacial da regra-matriz do ISS, e os elementos de conexão a ele relativos, e o critério material, no qual se analisa as perturbações na regra-matriz dos impostos sobre o consumo, definidas no texto constitucional decorrentes das transformações no processo ocupacional relativo às prestações de serviços face à (r)evolução tecnológica e comunicacional. Para tanto, preliminarmente analisamos a Federação brasileira e a repartição da competência tributária, analisando a rigidez de nosso sistema, revisitando temas como a repartição dos tributos sobre o consumo na Federação brasileira e a dicotomia "tipos e conceitos" na outorga constitucional. Além disto, nosso estudo volta-se ao tema da autonomia municipal, focando em aspectos relativos à proliferação de Municípios no Brasil, à situação destes

${ }^{11}$ Cf. Tabela "Receita operacional líquida, valor adicionado, salários, retiradas e outras remunerações, pessoal ocupado e número de empresas dos serviços empresariais não financeiros, segundo as atividades Brasil 2007-2008".

Disponível em

<http://www.ibge.gov.br/home/estatistica/economia/comercioeservico/pas/pas2008/tabelas_pdf/tab001.pd

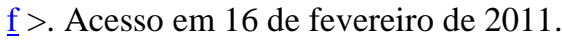


entes políticos no cenário brasileiro e à relevância da receita tributária própria na receita total.

Por fim, nossa investigação propõe uma esquematização das situações jurídicas possíveis no comércio eletrônico, aplicando a cada uma delas todo o arcabouço teórico investigado, propondo a adoção de soluções para a tributação das transações eletrônicas. Serão ainda testadas as soluções apresentadas em alguns exemplos de serviços que sofreram o impacto das tecnologias da informação e da comunicação. 


\section{CONSIDERAÇÕES PROPEDÊUTICAS GERAIS}

Toda abordagem que reivindica um caráter científico deve principiar descrevendo de forma clara e precisa suas premissas, o modelo conceitual e os fundamentos da pesquisa. Neste prefácio, teceremos algumas considerações sobre o arcabouço metodológico, contextualizaremos o cenário em que se insere nosso objeto de estudo e traçaremos um breve panorama da evolução tecnológica na área da informática e das telecomunicações.

\subsection{Serviços: Evolução e Relevância Econômica}

Na última década, o denominado "setor de serviços" foi responsável por mais de $60 \%$ do Produto Interno Bruto - PIB brasileiro, segundo dados do Instituto Brasileiro de Geografia e Estatística - IBGE, responsável técnico pela apuração e publicação periódica dos estudos estatísticos relativos às Contas Nacionais Trimestrais. ${ }^{12}$

12 Cf. Tabela III.3 do Relatório Indicadores Nacionais - Contas Nacionais Trimestrais, publicado em dezembro de 2010, p. 22. Disponível em: <http://www.ibge.gov.br/home/estatistica/indicadores/pib/pib- 
O crescimento do setor de serviços se intensificou no início do século $\mathrm{XX}^{13}$, como consequência do processo de industrialização e do surgimento do capitalismo, impulsionado pelo êxodo rural e pelo incremento da população urbana, resultado da necessidade crescente de mão-de-obra com o deslocamento da produção para outras atividades. Nas cidades, a falta de espaço para atividades antes desenvolvidas pelas famílias nas moradias, agora menores, levou à terceirização uma série de funções até então exercidas apenas naquele núcleo, como, por exemplo, a elaboração de refeições, a confecção de roupas, calçados e outras. ${ }^{14}$

Posteriormente, com a entrada das mulheres no mercado de trabalho, criaram-se novas carências e necessidades, sobretudo daquele grupo que demanda atenção especial - crianças e idosos, que sozinhos passaram a necessitar cuidados, antes supridos pela família, trazendo uma nova e crescente demanda por escolas, instituições de idosos, hospitais e outras atividades relacionadas. Esta necessidade foi ainda incrementada pelo aumento na expectativa de vida das pessoas, em função do desenvolvimento da medicina e pela incorporação de novas descobertas e tecnologias na área. Da mesma maneira, incentivados pela necessidade crescente de lazer e diversão para aqueles que cumpriam jornadas de trabalho cada vez mais longas e desgastantes, despontaram na área do entretenimento, esportes, lazer e turismo novas oportunidades para a prestação de serviços.

Portanto, o crescimento da população urbana assim como o aumento de sua expectativa de vida média foram fatores determinantes para o incremento da demanda de inúmeros serviços para os quais as pessoas não dispunham de tempo ou vontade para executar.

vol-al_201004caderno.pdf >. Acesso em 12 de abril de 2011. O IBGE é responsável pela elaboração do sistema de contas nacionais desde 1985, e em 1998, passou a seguir a nova orientação da ONU.

13 Podem-se distinguir três períodos de industrialização na história: (i) 1760 a 1850 - A Revolução se restringe à Inglaterra, a "oficina do mundo", sendo preponderantes a produção de bens de consumo, especialmente têxteis, e a energia a vapor; (ii) 1850 a 1900 - A Revolução espalha-se pela Europa, América e Ásia. Cresce a concorrência, a indústria de bens de produção se desenvolve, as ferrovias se expandem; surgem novas formas de energia, como a hidrelétrica e a derivada do petróleo. O transporte também se revoluciona, com a invenção da locomotiva e do barco a vapor; e (iii) 1900 até hoje - Surgem conglomerados industriais e multinacionais. A produção se automatiza; surge a produção em série; e explode a sociedade de consumo de massas, com a expansão dos meios de comunicação. Avança a indústria química e eletrônica, a engenharia genética, a robótica. Cf. <http://www.culturabrasil.pro.br/revolucaoindustrial.htm>. Acesso em 15 de abril de 2011. Cf. VASCONCELLOS, Marco Antonio Sandoval, Sistemas de Contabilidade Social: contas nacionais no Brasil, in Manual de Economia, Amaury Patrick Gremaud...[et al]; org. Diva Benevides Pinho e Marco Antonio S. Vasconcelos, 5a ed., São Paulo, Saraiva, 2004, p.289.

${ }^{14}$ Cf. BRAVERMAN, Harry, Trabalho e Capital Monopolista, Rio de Janeiro, Editora Guanabara, 1987, pp. 231. 
Mesmo com a crise mundial, que eclodiu no mundo em 2008, o setor de serviços prestados às famílias no Brasil manteve uma trajetória de expansão nos últimos anos. Os dados da Pesquisa Anual de Serviços 2010, divulgada pelo IBGE, demonstram que o setor apresentou crescimento de 44,9\% no período de 2007 a 2012 . $^{15}$

É neste cenário que potencialmente o imposto incidente sobre serviços de qualquer natureza, apesar de ainda pouco explorado pela maioria dos municípios brasileiros, poderá constituir a principal fonte de receita derivada para os municípios brasileiros, exercendo um papel relevante na receita tributária própria e, por consequência, na receita orçamentária total dos Municípios.

A arrecadação tributária própria dos Municípios no Brasil em 2009 representou na média nacional apenas $17,22 \%$ de suas receitas orçamentárias, com exceção da região Sudeste onde atingiu quase $23 \%$. ${ }^{16}$ Isto demonstra o potencial de crescimento destas receitas por meio da instituição dos tributos de competência municipal.

\subsection{Direito e Linguagem: o Método}

A todo aquele que se propõe estudar o direito como objeto, impõe-se a utilização de instrumentos adequados. Assim é que o "método científico", enquanto conjunto de regras lógico-comportamentais investigatórias que conduzem o pesquisador na busca de resultados para construir suas proposições científicas ${ }^{17}$, torna-se imprescindível, já que orienta o desenvolvimento do trabalho e auxilia na tomada de posição sobre conceitos fundamentais.

Neste sentido, quando se adota como premissa que a "compreensão se dá na linguagem, e segundo seus limites" ${ }^{18}$, adotando o método do construtivismo lógicosemântico, a hermenêutica se apresentará como ponto de partida para o estudo do Direito, disponibilizando ao exegeta, além dos instrumentos teóricos, os recursos a ela vinculados,

${ }^{15}$ Cf. NITAHARA, Akemi, Mesmo com a Crise Mundial, serviços prestados à família mantêm trajetória de crescimento, Disponível em: <http://agenciabrasil.ebc.com.br/noticia/2012-09-26/mesmo-com-crisemundial-servicos-prestados-familia-mantem-trajetoria-de-crescimento\#.UL-nsWHjIDE.mailto>. Acesso em 5 de dezembro de 2012.

BREMAEKER, Francois E. J, As Receitas Tributárias Municipais, in <http://www.oim.tmunicipal.org.br/abre_documento.cfm?arquivo=_repositorio/_oim/_documentos/772B EFF2-97EB-A456-AC5D09788463BB7D04102010091629.PDF\&i=1215>. Acesso em 22 de outubro de 2010.

${ }^{17}$ Cf. CARVAlho, Aurora Tomazini de, Curso de Teoria Geral do Direito: o Construtivismo LógicoSemântico, São Paulo, Noeses, 2009, p. 43.

${ }^{18}$ GAMA, Tácio Lacerda, Contribuição de Intervenção no Domínio Econômico, Quartier Latin, 2003, p.34. 
que lhe possibilitarão uma melhor compreensão e operacionalização da experiência jurídica.

A ênfase dos neopositivistas na linguagem explica-se justamente por sua utilização como instrumento base da ciência que a estuda, tomando-a como "modo de aquisição do saber científico, aplicada, por meio de mecanismos lógicos, na construção de modelos artificiais para a comunicação científica". ${ }^{19}$

Não se pode cogitar de manifestação do direito sem uma linguagem que lhe sirva de veículo de expressão. Assim, a linguagem não só fala do direito (ciência do direito), como participa de sua constituição (direito positivo). ${ }^{20}$ Considerar o direito como fenômeno linguístico significa admitir a existência de imprecisões (ambiguidades e vaguidades), ganhando força uma disciplina que busca investigar o direito enquanto linguagem e que tem trazido novas luzes sobre a tarefa hermenêutica em geral: a semiótica do direito.

A Semiótica, teoria geral dos signos ou ciência que estuda os signos, foi utilizada pela filosofia contemporânea como a Teoria da Semiose recortando metodologicamente o signo em três planos ou dimensões de análise: sintático, semântico e pragmático.

À sintaxe cabe estudar a relação dos signos entre si, a validade formal da norma segundo regras sintáticas que atribuem sentido ao enunciado. Por outro giro, se o arranjo dos vocábulos estiver composto de forma adequada, será possível compreendermos o sentido do enunciado.

Porém, a validade sintática não é suficiente para garantir o "conteúdo de verdade" do enunciado, inerente ao campo semântico. A semântica, que estuda os signos em suas relações com os objetos ou realidades que representem, atribuirá significação aos enunciados, permitindo aferir a compatibilidade entre o conteúdo das normas jurídicas e conferindo-lhes, ou não, o valor de verdade. ${ }^{21}$

O estudo semiótico em sua dimensão pragmática trata da relação dos signos com seus intérpretes, analisando a maneira como estes utilizam a língua em seus

${ }^{19}$ CARVALHO, Paulo de Barros, Direito Tributário - Linguagem e Método, São Paulo, Noeses, $1^{\mathrm{a}}$ ed. 2008 , p. 30.

${ }^{20}$ Cf. Idem, Fundamentos Jurídicos da Incidência, $2^{\text {a }}$. ed., Saraiva, 1999, p. 57.

${ }^{21}$ Cf. GAMA, Tácio Lacerda, Competência Tributária - Fundamentos para uma Teoria da Nulidade, São Paulo, Noeses, 2009, p. XXXVII (nota 28). 
discursos, para produzir mensagens e das alterações dos significados provocados por fatores intencionais.

E, considerando-se o Direito como plexo linguístico que se apresenta, seu estudo exige, além da utilização dos recursos semióticos, também os recursos lógicos como a análise do discurso e a influência da filosofia analítica e hermenêutica, ampliando a capacidade de investigação.

Este é o contexto atual do direito tributário que incorporou as ideias trazidas pelo movimento do giro-linguístico no qual a escolha do método para a investigação científica será tanto mais eficaz quanto lhe amplie a capacidade de compreensão da linguagem jurídica. ${ }^{22}$

E no estudo específico das normas de comportamento ligadas à instituição de tributos, não pode prescindir o exegeta do recurso da regra-matriz de incidência tributária que lhe atribuirá um sofisticado grau de compreensão, por meio da proposição de um itinerário a ser seguido para o estudo da estrutura normativa. O método lógico facilita sobremaneira o trabalho de interpretação dos textos do direito positivo, pois permite reduzir a um todo de sentido as proposições que, muitas vezes, encontram-se espalhadas entre vários diplomas legais.

Destarte, neste estudo das questões suscitadas na incidência tributária pelos fatos jurídicos de prestação de serviço através de meios eletrônicos, analisaremos os impactos havidos na estrutura interna normativa oriundos das alterações tecnológicas neste processo, utilizando como suporte metodológico a regra-matriz de incidência do Imposto sobre Serviços. Por outro giro, considerando que para haver a incidência de uma norma deve ocorrer o fato jurídico descrito em sua hipótese, nossa investigação se concentrará na similitude entre os eventos de prestação de serviços com a utilização dos modernos recursos tecnológicos e os predicados selecionados pelo legislador ao elaborar a hipótese da norma de incidência dos impostos.

É o direito positivo, enquanto disciplina dos comportamentos sociais intersubjetivos, vigente na denominada "Sociedade da Informação", que nos propomos investigar. Esta sociedade, baseada na circulação intensa e sofisticada de informações, utiliza-se de canais proporcionados pelas novas tecnologias computadorizadas, inerentes a

${ }^{22}$ O Giro-linguístico é um movimento filosófico que, tomando como premissa a relação entre linguagem e conhecimento, obteve os avanços teóricos propiciados pela filosofia da linguagem. Cf. GAMA, Tácio Lacerda, op. cit. (nota 18), p.30. 
todas as áreas da produção e do conhecimento, criando um novo ambiente de concretização de operações comerciais.

Alguns doutrinadores referem-se a uma "sociedade pós-industrial" de modo genérico; ocorre que a expressão “novas tecnologias” vinha sendo utilizada há algumas décadas para designar os processos de comunicação de massa, como cinema, radiodifusão e comunicação por satélite, e de reprodução para o mercado de consumo em um mundo moderno, pós-industrial. ${ }^{23}$

Com o desenvolvimento da atual infraestrutura de informações e a formação de um ambiente digital global, surgiu o fenômeno conhecido como Sociedade da Informação. A expressão, normalmente associada às modernas tecnologias da informação, abarca ainda inovações tecnológicas, sobretudo no campo das telecomunicações. No fenômeno típico do final do século XX, denominado por alguns como "convergência digital", as tradicionais fronteiras tecnológicas perderam o sentido, já que os variados conteúdos utilizam como suporte meios sempre similares. ${ }^{24}$

Estas transformações culturais não resultaram somente do advento das novas tecnologias e dos novos meios de comunicação, já que estes constituem meros canais de transmissão da informação, suportes materiais e canais físicos em que a linguagem se corporifica e transita. São os novos tipos de signos que circulam nestes meios que propiciaram o surgimento de um novo ambiente sociocultural. As mídias restariam desprovidas de sentido sem as mensagens que se configuram nelas. ${ }^{25}$

Com estas tecnologias e suas linguagens, o consumo massivo deu lugar ao consumo individualizado, propiciando a escolha, que caracteriza a cultura das mídias. A recepção de mensagens foi substituída pela busca da informação e do entretenimento que desejamos encontrar. Esta busca pela informação é dispersa, não-linear e fragmentada, no entanto, individualizada. E o cenário é de exacerbação na produção e circulação da informação. ${ }^{26}$

23. O conceito de sociedade "pós-industrial" foi proposto por Willis Santiago Guerra Filho, utilizado também por doutrinadores como Paul Virillo e Luhmann e adotado por Clarice Araújo. Cf. ARAUJO, Clarice Von Oertzen, Semiótica do Direito, São Paulo, Quartier Latin, 2005, p. 19 e nota 17.

${ }^{24}$ Cf. SANTOS, Manoel J. Pereira, O Direito Autoral na Internet, In Direito e Internet - Relações Jurídicas na Sociedade Informatizada, Marco Aurelio Greco e Ives Gandra da Silva Martins (coords.), São Paulo, Revista dos Tribunais, 2001, p. 138

${ }^{25}$ Cf. SANTAELlA, Lúcia, Da Cultura das Mídias à Cibercultura: o Advento do Pós-Humano. Disponível em: <http://revistaseletronicas.pucrs.br/ojs/index.php/revistafamecos/article/viewFile/3229/2493〉, pp. 23-27. Acesso em 20 de novembro de 2012.

${ }^{26}$ Cf. Idem, ibidem, pp. 23-27. 
Nesta sociedade da informação, a Internet não pode ser considerada como mero ambiente de comunicação e intercâmbio de informações; nela são oferecidas extraordinárias oportunidades de negócios em todos os setores da economia, dando azo a fenômenos como o comércio eletrônico, que nos propomos estudar.

Nossa investigação se dará por meio do isolamento da regra de competência e dos critérios do antecedente da norma geral e abstrata do ISSQN, iniciandose pelo critério espacial, perquirindo os efeitos da virtualização dos processos nestes tempos de armazenamento em "nuvem". No mesmo diapasão, o critério material conduzirá a análise dos "novos serviços" surgidos em função da tecnologia, oferecendo subsídios para perquirirmos a real natureza jurídica daquelas transações cujo procedimento desenvolve-se inteiramente em ambiente eletrônico, abrangendo inclusive a entrega eletrônica do bem ou serviço.

Mas impõe-se ao tema uma pesquisa semântica específica, voltada à linguagem informática, buscando uma precisão na definição de conceitos e termos do idioma inglês, tomados em convenção internacional, e sua relação com os signos presuntivos de riqueza eleitos pelo constituinte para instituir os impostos. Por outro giro, “ninguém poderá responder à pergunta, aparentemente singela, sobe a incidência ou não de tributos como o ICMS ou o ISSQN, nos casos de serviços de acesso à 'rede das redes' (Internet) ou de serviços prestados por seu intermédio, se não dispuser do domínio semântico adequado àquele aparato de signos". ${ }^{27}$

Fazendo uso deste método e usando os recursos hermenêuticos e lógicos é que procuramos discutir e trazer uma nova luz ao estudo da aquisição eletrônica de bens e serviços, fornecendo reflexões sobre a necessidade ou não de alterações nas normas do Direito Positivo, com vistas a adaptá-lo às novas realidades tecnológicas e econômicas.

\subsection{A Semiótica e a Informática}

Considerando que nosso estudo tem como cenário a revolução e o crescente desenvolvimento das tecnologias da informação e da comunicação, deve-se ter em mente que, concomitante a tais avanços, são introduzidos novos tipos de códigos, que passam a concorrer com a hegemonia linguística de até então.

27 CARVAlHO, Paulo de Barros, Prefácio de OLIVEIRA, Julio Maria de, Internet e Competência Tributária, São Paulo, Dialética, 2001. 
Neste cenário, a investigação destes fenômenos supõe a interface necessária entre as várias linguagens, como a do direito positivo e a linguagem técnica da tecnologia da informação, impondo que se recorra a um método científico que permita a interpretação destes fenômenos.

Destarte, "a utilização da semiótica como método de pesquisa vem possibilitar também a interpretação de fenômenos registrados a rigor em qualquer tipo de código, o que torna o método por excelência na análise de fenômenos culturais". ${ }^{28}$

A semiótica compreende os processos comunicativos das mídias como atividade e processos culturais que geram códigos próprios e signos peculiares. ${ }^{29}$

Nesta nova realidade econômica e social surgem novos sistemas de comunicação, entre os quais também se consideram como tal "os sistemas econômicos para traficar, não em ideias, mas em bens e serviços materiais; os sinais de comunicação são moedas, títulos, cartas de crédito, e assim por diante.” A vida nas cidades modernas depende cada vez mais de meios de comunicação, que são auxiliares técnicos que viabilizam a vida social, à medida que comunicação significa organização. ${ }^{30}$

Inegável que nesta sociedade existe simultaneamente uma série de outras linguagens, de forma que o termo hoje assume o significado "de uma gama incrivelmente intrincada de formas sociais de comunicação e de significação que inclui a linguagem verbal, mas absorve também [...] tantos outros". 31

Nosso cotidiano após o século XX é repleto de mensagens e informações produzidas, armazenadas e difundidas em linguagens, reproduzidas na fotografia, no cinema, no rádio, na televisão, nas fitas magnéticas. Tais mudanças, que se operaram no mundo da linguagem, possibilitam que hoje tenhamos em nossas casas, de forma similar ao abastecimento de água, energia elétrica ou gás, a difusão de uma enorme gama de imagens, filmes e sons. ${ }^{32}$

Trata-se de sistemas de comunicação que se estruturam em linguagem, assim entendidos os vários sistemas sociais de comunicação, abrangendo inclusive aquelas

${ }^{28}$ Cf. ARAUJO, Clarice Von Oertzen, op.cit. (nota 23), p. 54.

${ }^{29}$ Cf. SANTAELLA, op. cit, (nota 25), p. 29

${ }^{30}$ JAKOBSON, Linguistica. Poética. Cinema, São Paulo, Perspectiva, 1970, p. 24, Apud ARAUJO, Clarice Von Oertzen, op. cit. (nota 23), p. 56.

${ }^{31}$ SANTAELLA, Lúcia, O que é Semiótica? 32a reimpressão da $1^{\mathrm{a}}$. ed. de 1983, São Paulo, Braziliense, 2012, p. 16.

${ }^{32}$ Idem, ibidem, p. 17. 
linguagens binárias utilizadas pelo homem para se comunicar com as máquinas, como a linguagem de computador.

As linguagens que descrevem algoritmos pertencem a dois subconjuntos: ou trata-se de uma linguagem natural, como francês ou inglês, ou pode ser uma linguagem artificial construída, como por exemplo, as linguagens de programação Fortran, Lisp, Pascal, C+. Esta linguagem, que descreve as operações a serem executadas pelas máquinas, também é especificada por um conjunto de regras de sintaxe, e possui uma semântica própria, que depende exclusivamente do que se deseja causar objetivamente quando o programa for executado. ${ }^{33}$

A sintaxe das linguagens de programação refere-se à forma dos programas, abarcando a correção da escrita que compõe o programa, o relacionamento entre os símbolos e as frases que ocorrem nesses programas, e aspectos como a colocação de frases de modo não ambíguo.

Já a semântica modela os fenômenos que o programa causará na máquina quando for executado, controlando as luzes que se acenderão, a corrente elétrica que fluirá pelos circuitos, as letras ou símbolos que aparecerão na tela, independentemente do seu uso nesse ou naquele computador. Ou seja, a semântica da linguagem de programação é o conjunto de regras que determina a ordem na qual as operações do programa irão ser executadas, e quando se encerrarão.

\subsection{Tecnologias da Informação e Comunicação}

Estudar e refletir sobre o impacto tributário oriundo dos fenômenos tecnológicos relacionados à informação e comunicação implicam investigar a origem e a evolução destas ciências e qual a contribuição de cada uma delas no estágio tecnológico atual.

Neste contexto, traçaremos um sucinto histórico da computação, das telecomunicações e do fenômeno da Internet, seguros de que constituirá um importante referencial e aporte teórico para a compreensão dos fenômenos jurídicos a que nos propusemos estudar no momento presente.

33 Cf. FONSECA FILHO, Cléuzio, História da computação [recurso eletrônico]: O Caminho do Pensamento e da Tecnologia, Porto Alegre, EDIPUCRS, 2007, p. 109. Disponível em: <http://www.pucrs.br/edipucrs/online/historiadacomputacao.pdf > . Acesso em 5 de novembro de 2012. 


\subsubsection{A Era dos Computadores}

Não há dúvida de que os computadores representam um marco na revolução tecnológica que vivenciamos. A história da Ciência da Computação, apesar de recente comparativamente a outras áreas, avança de forma exponencial.

Estes dispositivos foram possibilitados pelas descobertas teóricas de homens que durante séculos acreditaram ser possível aumentar a capacidade intelectual humana nos processos de cálculo aritmético e criar dispositivos para substituir os aspectos mais mecânicos do modo de pensar do homem, repassando às máquinas aquelas tarefas repetitivas ou demasiado simples. ${ }^{34}$

A Ciência da Computação surgiu e se fundamentou com base na evolução da álgebra e da lógica. A humanidade experimentou, na passagem do século XVIII para o século XIX, uma evolução na História da Matemática superior a qualquer outro período precedente. ${ }^{35}$

Foi um matemático, Charles Boole (1815-1864), que desenvolveu o primeiro sistema formal para raciocínio lógico, sendo ainda o primeiro a enfatizar a possibilidade de se aplicar o cálculo formal a diferentes situações. Sem a álgebra booleana, a tecnologia computacional não teria progredido com facilidade até a velocidade da eletrônica.

Foi sua ideia de um sistema matemático baseado em apenas duas quantidades, o "Universo" e o "Nada", representadas por 1 e 0 , que possibilitou o desenvolvimento de um sistema de dois estados para a quantificação lógica. ${ }^{36}$

Outros dois matemáticos foram fundamentais para o desenvolvimento da álgebra: Frege (1848-1925) e Peano (1858-1932). Contemporânea de Russell e Wittgenstein, a lógica de Frege não é o que hoje chamamos de Lógica, fruto do formalismo e da teoria dos conjuntos que acabaram por predominar entre os matemáticos, mas sim a semântica, disciplina sobre o conteúdo, natureza desse conteúdo e estrutura.

Em 1927 o matemático Max Neumann publicou cinco artigos que impactaram fortemente o mundo acadêmico; entre eles, um estabelecia um novo campo de

\footnotetext{
${ }^{34}$ Cf. FONSECA FILHO, Cléuzio, op. cit. (nota 33). Acesso em 5 de novembro de 2012.

${ }^{35} \mathrm{Cf}$. Idem, ibidem. Acesso em 5 de novembro de 2012.

${ }^{36}$ Cf. Idem, ibidem. Acesso em 5 de novembro de 2012.
} 
pesquisas chamado "Teoria dos Jogos", e outro impactou o desenvolvimento da Computação: era o estudo do relacionamento entre sistemas formais lógicos e os limites da matemática. ${ }^{37}$

O sistema de dois valores de Charles Boole foi utilizado mais tarde pelos construtores do primeiro computador para compor mecanismos capazes de realizar cálculos. Experiências com máquinas que efetuavam cálculos e tabulavam dados foram, no final do século XIX, as precursoras dos computadores.

O ábaco e o quadrante, que foram os primeiros dispositivos utilizados para auxiliar o homem a calcular, têm sua origem perdida no tempo x. O ábaco já era utilizado em 3.000 a.C. na Babilônia, sendo capaz de resolver problemas de adição, subtração, multiplicação e divisão de até 12 inteiros, além de também haver notícia de sua utilização pelas civilizações egípcia, grega, chinesa e romana.

Em 1630 tornou-se pública a grande invenção do matemático William Oughtred: a régua de cálculo, que em 1650 ganhou sua forma atual, foi esquecida por duzentos anos e se tornou, no século XX, símbolo de avanço tecnológico, sendo posteriormente substituída pelas calculadoras eletrônicas. ${ }^{38}$

A revolução dos computadores começou a acontecer, de fato, no ano de 1935 com Alan Mathison Turing (1912-1954), aluno de Neumann, que "demonstrou ser possível executar operações computacionais sobre a teoria dos números por meio de um equipamento em que estivessem embutidas as regras de um sistema formal". ${ }^{39}$

A descoberta de Turing e os matemáticos da época que desenvolveram um novo tipo de cálculo lógico tornaram-se a base teórica da Ciência da Computação. Os conceitos utilizados por Turing para construir a Máquina de Turing Universal, um dos primeiros modelos de máquina abstrata, estão presentes ainda hoje, com os mesmos princípios, nos computadores digitais. Considerada como o "cume atingido, e ainda não ultrapassado", a Máquina de Turing era um "modelo abstrato de equipamento, com capacidade de processar complicadas linguagens e calcular o valor de funções aritméticas não triviais". ${ }^{40}$

${ }^{37}$ Cf. FONSECA FILHO, Cléuzio, op. cit. (nota 33). Acesso em 5 de novembro de 2012.

${ }^{38} \mathrm{Cf}$. Idem, ibidem. Acesso em 5 de novembro de 2012.

${ }^{39}$ EMERENCIANO, Adelmo da Silva, Tributação no Comércio Eletrônico, Coleção de Estudos Tributários, Paulo de Barros Carvalho coordenador, Síntese e Thomson IOB, São Paulo, 2003, p. 26.

${ }^{40}$ Cf. FONSECA FILHO, Cléuzio, op. cit. (nota 33). Acesso em 5 de novembro de 2012. 
Em 1940, Turing foi convocado para a Segunda Grande Guerra pelo governo inglês para decifrar mensagens codificadas do inimigo na Escola Britânica de Códigos, que era dominada por vários linguistas e filólogos, que possuíam, segundo o governo britânico, melhores condições para a tarefa. ${ }^{41}$

No retorno de uma viagem à América, onde foi enviado para trocar informações com o serviço de inteligência norte-americano e conhecer os projetos relacionados a computadores, Turing detinha conhecimento sobre novas tecnologias eletrônicas, que seriam utilizadas no aprimoramento dos circuitos lógicos existentes.

Trabalhando junto à ACE - Automatic Computing Engine, Turing publicou um artigo, Computing Machinery and Intelligence (1950), em que abordava a possibilidade da construção de máquinas cujo funcionamento imitasse o funcionamento do cérebro humano.

Mas um dos grandes pioneiros da era dos computadores é o matemático e astrônomo inglês Charles Babbage (1792-1871). Em 1822 ele elaborou o projeto de um dispositivo mecânico feito de latão e madeira, concebido para executar uma série de cálculos, que poderia ter alterado a história da computação se tivesse sido construído. Posteriormente desenvolveu um projeto de outra máquina capaz de auxiliar na tarefa de construção das tabelas matemáticas que eram desenvolvidas na época com erros, como as de multiplicação, seno, coseno ou logaritmos.

O estado da arte em relação aos computadores foi alterado por Herman Hollerith, funcionário do United States Census Office, que venceu em 1890 a concorrência para o desenvolvimento de um equipamento de processamento de dados para auxiliar o censo norte-americano daquele ano. ${ }^{42}$ Hollerith inspirou-se em um sistema de cartões perfurados desenvolvido para teares por Jackard, desenvolvendo uma máquina que representava nas perfurações em cada cartão de registro não apenas números gerais, mas também as características individuais, e que interpretava, classificava e manipulava somas aritméticas, realizando até mesmo tabulações cruzadas.

Fundou, para tanto, uma empresa, a Hollerith Tabulating Machines, que em 1914 se uniu a outras duas empresas para compor a CTR - Computer Tabulating

${ }^{41}$ Cf. FONSECA FILHO, Cléuzio, op. cit. (nota 33). Acesso em 5 de novembro de 2012.

42 Herman Hollerith. History. U.S. Census Bureau. Disponível em: $<$ http://www.census.gov/history/www/census then now/notable_alumni/herman hollerith.html $>$. Acesso em 15 de novembro de 2012. 
Recording Company, renomeada em 1924 como International Business Machine Corporation - IBM.

Centros de pesquisa criados nos primeiros anos do século $\mathrm{XX}$ em Harvard, na IBM e na General Electric, entre outros, dedicaram-se ao estudo de questões fundamentais da área de eletricidade, obtendo sucesso na formulação matemática dos problemas em teoria de circuitos.

Vannevar Bush criou em 1931 um computador analógico que resolvia equações diferencias ordinárias por meios mecânicos. ${ }^{43}$ Konrad Zuse desenvolveu em 1936 o Z1, um computador construído inteiramente com peças mecânicas e que usava uma fita de película cinematográfica para as instruções que controlavam a máquina.

Mas o primeiro modelo totalmente operacional foi o Z3, construído em 1941, e que, como as máquinas da primeira geração, "usava dois mecanismos separados para as funções aritméticas e tinha uma unidade especial para conversão de números na notação decimal para a binária". ${ }^{44}$

Em 1934, foi construído o IBM Automatic Sequence Controlled Calculator que, além de utilizar memórias separadas para instruções e dados, apresentava novas capacidades: "modificava instruções dinamicamente baseando-se nos resultados obtidos durante o processamento, possuía unidades para decidir qual o melhor algoritmo para execução de um cálculo através do argumento de uma função, testava o conteúdo de registradores, etc." 45

O primeiro grande computador, realmente funcional como tal, foi o ENIAC - Electronic Numerical Integrator and Computer, que surgiu em 1946 e representou um grande salto no desenvolvimento dos computadores eletrônicos. O equipamento em forma de "U" ocupava mais de 170 metros quadrados, pesava 30 toneladas e possuía 18 mil válvulas. Os dados continuavam a ingressar na máquina através de cartões perfurados e a programação era feita manualmente.

Neste período, duas importantes revoluções tecnológicas ocorreram em relação aos computadores: o uso de válvulas, que lhes agregou velocidade e confiabilidade, e os dispositivos de armazenamento com a introdução de "memória" de núcleo magnético, considerada um marco no desenvolvimento dos computadores. Em 1951, a Remington-

\footnotetext{
${ }^{43}$ Cf. EMERENCIANO, Adelmo da Silva, op. cit. (nota 39), p. 27.

${ }^{44}$ FONSECA FILHO, Cléuzio, op. cit. (nota 33). Acesso em 5 de novembro de 2012.

${ }^{45}$ Idem, ibidem. Acesso em 5 de novembro de 2012.
} 
Rand disponibilizou comercialmente o primeiro computador que utilizava esses conceitos, o UNIVAC I - Universal Automatic Calculator.

A evolução dos computadores é definida por classificações denominadas "gerações"; a primeira geração de computadores, que se estendeu até 1956, caracterizou-se pela utilização da tecnologia baseada em válvulas. Os computadores da segunda geração (1956-1963) funcionavam com transistores que foram inventados em 1948 e realizavam cálculos em microssegundos. O computador de maior sucesso dessa geração foi o IBM 7094 que, apesar de pesar 890 quilos, representava um grande avanço em relação ao ENIAC, e vendeu mais de 10 mil unidades.

A terceira geração (1964-1970) tem início com a substituição dos transistores pela tecnologia dos circuitos integrados, introduzidos no mercado pela Texas Instruments e pela Fairchild Semiconductor. Entre o final da década de 1970 e início da década de 1980 os computadores passaram a ser mais "acessíveis".

A introdução do chip, uma pastilha de silício onde são "impressos" diretamente os componentes eletrônicos, dá início em 1971 à quarta geração de computadores, que se caracteriza pelo surgimento dos denominados "microcomputadores", nome atribuído em função do peso de menos de 20 quilos, o que tornou o armazenamento deles muito facilitado.

Mas os computadores ainda constituíam um privilégio das grandes instituições empresariais e de experimentações acadêmicas nos avançados laboratórios dos Estados Unidos. A barreira que cercava as grandes máquinas e a "elite tecnológica" que as manipulava foi rompida a partir de 1975, quando começaram a ser comercializados os computadores pessoais, que possibilitou a transferência do controle do computador a milhares de pessoas, transformando-o em bem de consumo.

As linguagens de computação, fundadas nos conceitos de Von Neumann a respeito dos programas em linguagem de máquina, avançaram das linguagens simbólicas para as de segunda geração, denominadas procedure-oriented, ou seja, orientadas para os procedimentos de aplicação; em 1990 o paradigma da programação “orientada a objetos", resultado das novas arquiteturas, foi amplamente difundido. ${ }^{46}$

A disseminação da Internet e o incremento do comércio eletrônico ampliaram as complexidades no desenvolvimento de programas, já que os aplicativos

\footnotetext{
${ }^{46}$ Cf. EMERENCIANO, Adelmo da Silva, op. cit. (nota 39), p. 28.
} 
devem ser desenvolvidos em linguagens que lhes possibilitem atuar em contextos heterogêneos, com arquiteturas de hardware e sistemas operacionais incompatíveis, plataformas operando com mais de uma interface gráfica, etc. Surgiram, desta forma, novas linguagens como a linguagem JAVA, concebida pela Sun Microsystems, com qualidades de "portabilidade" e desenvolvida com um conceito de "arquitetura neutra". A portabilidade permite que sistemas heterogêneos componham uma rede como a Internet, por exemplo, e as diferentes características dessa rede; na arquitetura neutra, o código objeto pode ser executado em qualquer computador, com qualquer sistema operacional, desde que faça o download da Máquina Virtual Java, que implementa o ambiente necessário. $^{47}$

Hodiernamente, componentes informáticos como memórias e processadores estão presentes em outros dispositivos que não em computadores propriamente ditos, como cartões eletrônicos, distribuidores automáticos, robôs, aparelhos eletrodomésticos, fotocopiadoras, câmeras de vídeo, telefones, rádios, televisões, ou em qualquer outro dispositivo em que a informação digital seja processada automaticamente. 48

\subsubsection{A Evolução das Telecomunicações}

Paralelamente ao aperfeiçoamento progressivo dos computadores, a partir do século XIX as experiências tecnológicas impulsionadas pelo domínio do uso da eletricidade voltaram-se aos processos de comunicação humana, revolucionando os sistemas de transmissão de saber e das relações humanas, rompendo com os paradigmas de espaço e tempo então vigentes.

Desde que o homem dominou a escrita, por volta de 3 mil anos antes de Cristo, passando a se utilizar de sinais (símbolos) para exprimir as ideias humanas, sua história e conquistas podiam ser transmitidas de uma geração à outra. ${ }^{49}$

Mas o telégrafo e a digitalização do alfabeto no Código Morse em 1837 reformularam as noções de espacialidade (lançando a expressão verbal para espaços muito

${ }^{47}$ Cf. FONSECA FILHO, Cléuzio, op. cit. (nota 33). Acesso em 5 de novembro de 2012.

${ }^{48}$ Cf. LEVY, Pierre, O que é o Virtual? Tradução de Qu'est-ce que Le Virtuel? de Paul Neves, Rio de Janeiro, Ed. 34, 1996, p. 47.

${ }^{49}$ CORREA, Rafael, A Era da Conectividade, Revista Veja Edição 2299, Dezembro 2012, pp. 157-160. 
além do presencial) e temporalidade (em um lapso de tempo incomparável em relação às tecnologias anteriores) dos sistemas de expressão. ${ }^{50}$

A virtualização de uma informação, um ato, um texto os torna "nãopresentes", fazendo com que se desterritorializem. "Uma espécie de desengate os separa do espaço físico ou geográfico ordinário e da temporalidade do relógio ou do calendário". 51

As transmissões telegráficas passaram a ser usadas mundialmente como forma de comunicação, depois da inauguração de um telégrafo ligando a Europa às Américas em 1866.

A invenção do fonógrafo em 1878 por Thomas Edison e do daguerreótipo por Daguerre em 1838 possibilitou a fixação no tempo, respectivamente, do som e da imagem. O fonógrafo era um aparelho que registrava e reproduzia o som; o daguerreótipo era um processo químico que permitia obter uma imagem fotográfica sobre um suporte metálico. Simultaneamente foi desenvolvido na Inglaterra por Fox Talbot um aparelho similar, denominado talbótipo ou calótipo, sendo ambos (Talbot e Daguerre) considerados os "pais da fotografia".

Os novos inventos possibilitaram que o som e a imagem fossem reproduzidos e difundidos por múltiplos usuários. Da mesma forma, no dia 7 de março de 1876, com a invenção do telefone pelo escocês naturalizado norte-americano Alexander Graham Bell, passou a ser possível o envio do som, normalmente a voz humana, à longa distância. Unindo de forma ímpar a reprodução dos sons e a transmissão à distância, o aparelho alterou as comunicações de uma forma substancial, que se tornou o marco de uma nova era na história da humanidade.

A primeira ligação transcontinental, em 1915, entre Alexander Bell de Nova York e Thomas Watson de São Francisco, deu início ao uso em massa do telefone, sendo considerada o marco de uma nova era de comunicação global. ${ }^{52}$

No Brasil, em 15 de novembro de 1879, Dom Pedro II outorga a Charles Paulo Mackie, representante da Bell Telephone Company, a autorização para exploração dos serviços telefônicos no país.

${ }^{50}$ Cf. ARANHA, Glaucio, O Processo de Consolidação dos Jogos Eletrônicos como Instrumento de Comunicação e de Construção de Conhecimento. Ciências \& Cognição 2004; Vol 03: 21-62 Disponível em: 〈http://www.cienciasecognicao.org/revista/index.php/cec/article/view/473〉. [Recurso Eletrônico]. Publicado on line em 31 de Novembro de 2004. Acesso em 15 de novembro de 2012.

${ }^{51}$ Cf. LEVY, Pierre, op. cit. (nota 48), p. 21.

${ }^{52}$ CORREA, Rafael, op. cit. (nota 49), pp. 157-160. 
Outra importante descoberta no campo das comunicações, que possibilitou as atuais tecnologias "sem fio", ocorreu em 1887 pelo físico alemão Heinrich Hertz. Produzindo ondas de rádio, ele demonstrou que possuíam as mesmas propriedades da luz; eram as ondas eletromagnéticas, hoje denominadas ondas hertzianas, que possibilitaram, entre outras coisas, a comunicação atual por rádio, televisão e telefone celular. $^{53}$

Em 1896, o italiano Guglielmo Marconi deposita sua primeira patente sobre transmissão sem fio por ondas de rádio; em 1901, demonstra o radiotelégrafo fazendo uma transmissão que cruza o Oceano Atlântico.

Anos mais tarde, em 1912, o norte-americano Lee De Forest desenvolve um amplificador construído com válvula tríodo ${ }^{54}$ usada na telegrafia sem fio. No mesmo ano, o pedido de socorro do navio Titanic, emitido por ondas de rádio, é captado a 58 milhas e possibilitou o resgate de 705 passageiros apenas três horas e meia depois da emissão do SOS.

Neste cenário de evolução, surge em 1923 a televisão, inventada por Vladimir Zwoykin. Três anos mais tarde, John Baird transmite imagens de televisão através de fios telefônicos de Londres para Glasgow. O serviço de radiodifusão regular de televisão iniciou-se na Alemanha em 1935, na Inglaterra em 1936 e nos Estados Unidos em 1939. ${ }^{55}$

O serviço de telefonia transatlântica entre Londres e Nova York se iniciou em 1926. O Pager foi introduzido como um produto de comunicação via rádio em 1955, sendo amplamente utilizado por hospitais e fábricas. Neste ano, segundo dados da época, quase $50 \%$ da população norte-americana economicamente ativa já se dedicavam a atividades industriais, comerciais, culturais e sociais relacionadas à coleta, tratamento e disseminação da informação. ${ }^{56}$

${ }^{53}$ Cf. NETO, Pedro de Alcantara, História das Comunicações e das Telecomunicações, Disponível em: <http://www2.ee.ufpe.br/codec/Historia\%20das\%20comunicaes $\% 20 \mathrm{e} \% 20 \mathrm{das} \% 20$ telecomunicaes_UPE.p df> . Acesso em 15 de novembro de 2012.

${ }^{54}$ Verbete "tríodo": válvula de três elétrodos que contém um ânodo, um cátodo e um elétrodo de controle. HOUAISS, Dicionário Eletrônico. Disponível em 〈http://houaiss.uol.com.br/gramatica.jhtm〉. Acesso em 13 de novembro de 2012.

55 Cf. CAMPOS, Sarmento, Cronologia das Telecomunicações. Disponível em: <http://www.sarmento.eng.br/Telecomunicacoes.htm>. Acesso em 15 de novembro de 2012.

${ }^{56}$ Cf. FONSECA FILHO, Cléuzio, op. cit. (nota 33). Acesso em 5 de novembro de 2012. 
Cinco anos mais tarde, em 1960, o primeiro satélite passivo de comunicação é lançado, e a reflexão de sinais de rádio de volta para a Terra foi obtida com êxito. Em 1963, o primeiro satélite de comunicação é colocado em órbita geoestacionária.

Em 1969, surge a ARPANET, instalada nos Estados Unidos pelo Departamento de Defesa, que evoluiu para transformar-se na Internet, dando início a uma nova era de telecomunicações no mundo.

No Brasil, até o Plano de Metas editado pelo governo de Juscelino Kubitschek (1956 a 1961), o setor das telecomunicações vivia uma fase embrionária; o documento revelou a necessidade de um sistema nacional de telecomunicações "que facilitasse e agilizasse a difusão de informações, com o objetivo de atingir a esperada 'integração nacional'”. 57

Jânio Quadros criou no início de seu governo o Conselho Nacional de Telecomunicações (CONTEL), e em 1964, no governo de João Goulart, foi aprovado o Código Brasileiro de Telecomunicações (CBT), inspirado em estudos do Estado Maior das Forças Armadas, que passou a dirigir o setor, centralizando o poder regulatório e criando um sistema nacional. Com o início dos governos militares em 1964, a infraestrutura de telecomunicações foi modernizada, já necessária à segurança e ao desenvolvimento da integração nacional.

No tocante à transmissão de dados, em 1982, a Embratel lançou um projeto piloto de uma rede de serviços de informação, a Ciranda, restrita aos funcionários da empresa, que oferecia serviços como correio eletrônico, acesso a algumas bases de dados de informações corporativas (benefícios fornecidos pela empresa, convênios etc.), agenda de aniversários, guia de compras e alguns jogos.

A integração em grande escala da televisão, telecomunicação e informática, em um processo de configuração de redes informativas, começou a partir dos anos de 1970. A base tecnológica era digital, com grande capacidade de transmitir dados, fotos, gráficos, textos e imagens difundidos em vários meios impressos e audiovisuais, tudo em formato eletrônico ou digital, começando a partir daí, a serem suprimidas as

${ }^{57}$ Cf. CARVALHO, Marcelo Sávio Revoredo Menezes, A Trajetória da Internet no Brasil: do Surgimento das Redes de Computadores à Instituição dos Mecanismos de Governança, Dissertação - Universidade Federal do Rio de Janeiro, pp. 63-65. Disponível em: <http://www.nethistory.info/Resources/InternetBR-Dissertacao-Mestrado-MSavio-v1.2.pdf>. Acesso em 06 de novembro de 2012. 
mídias. Esta integração dos meios de comunição estaria gerando "uma progressiva fusão das atividades intelectuais e industriais do campo da informação". 58

A primeira rede de telefonia celular do mundo foi construída no Japão em 1979, fato igualado pelos Estados Unidos da América somente em 1983. Um ano mais tarde (1984) a Internet se torna mundial, e a partir de 1995 os telefones celulares passam a prover acesso à Internet e vídeo.

As grandes inovações havidas nos últimos anos no setor das telecomunicações têm sido possibilitadas pela tecnologia wireless, denominada a “comunicação sem fio". Desde 2004, a comunicação wireless passou a ser disponibilizada ao uso público em aeroportos, universidades e vários espaços públicos, além de ser muito utilizada em empresas e nas residências. 59

As redes wireless e a tecnologia $3 \mathrm{G}$ dos smartphones fizeram com que atividades antes realizadas somente no escritório ou em casa passassem a ser realizadas também na sala de conferências, no carro, no aeroporto, no hotel e até mesmo no café.

\subsubsection{Computadores Pessoais: evolução tecnológica ou revolução social?}

A industrialização dos computadores pessoais e o aparecimento da computação multimídia ${ }^{60}$ representaram um salto na história da computação, possibilitado pela disseminação dos circuitos integrados. ${ }^{61}$

Em 1975, chegou ao mercado o primeiro minicomputador, vendido em kit para ser montado pelo próprio usuário: o Altair 880, construído com um chip da Intel; o sucesso foi imediato, com a venda de 4 mil unidades em três meses. Em função deste computador, dois jovens, Paul Allen e Willians Gates, uniram-se para conceber uma versão

${ }^{58}$ Cf. FONSECA FILHO, Cléuzio, op. cit. (nota 33). Acesso em 5 de novembro de 2012.

59 Wireless é a transmissão de rádio através do ar. Embora todas as formas de transmissão pelo ar (AM, FM, $\mathrm{TV}$, telefones portáteis casa, celulares, etc) sejam naturalmente feitas sem a utilização de fios, o termo é normalmente empregado para se referir apenas à Wi-Fi ou a serviços de dados celulares. PC Magazine Encyclopedia, PCMAC.COM, Disponível em: 〈http://www.pcmag.com/encyclopedia $>$. Acesso em $06 \mathrm{de}$ novembro de 2012.

60 Multimídia "significa, em princípio, aquilo que emprega diversos suportes ou diversos veículos de comunicação". LÉVY, Pierre, Cibercultura, editora 34, p. 67. Verbete "Multimídia”: técnica para apresentação de informações que recorre simultaneamente a diversos meios de comunicação, mesclando texto, som, vibrações e movimentos mecânicos e imagens fixas e animadas.

${ }^{61}$ Cf. FONSECA FILHO, Cléuzio, op. cit. (nota 33). Acesso em 5 de novembro de 2012. 
popular de uma linguagem computacional para o Altair, o Basic. Eles fundaram mais tarde a Microsoft, que na década de 1990 foi uma das mais bem-sucedidas empresas de software do mundo.

Na metade da década de 1970, formou-se no Silicon Valley uma comunidade de jovens, considerada como responsável pela invenção do computador pessoal, que tinha um projeto "mais ou menos definido de instituir novas bases para a informática e, ao mesmo tempo, revolucionar a sociedade". ${ }^{62}$

No local, estavam implantadas, entre outras, a NASA, a HewlettPackard, a Atari e a Intel, sendo que todas as escolas da região ofereciam cursos de eletrônica. Os jovens aproveitavam a abundância e variedade de componentes eletrônicos e os laboratórios e computadores da Universidade de Stanford e divertiam-se fabricando rádios, amplificadores e dispositivos de telecomunicação, pregando ideias sobre o desvio da alta tecnologia em proveito da "contracultura" e difundindo frases como "computadores para o povo".

Os grupos que se formaram tinham como hábito a venda e a troca de componentes, programas e ideias e, desta profusão de coisas, pessoas e ideais, surgiu o computador pessoal, não o objeto em si, mas o "complexo de circuitos eletrônicos e de utopia social que era o computador pessoal no fim dos anos de 1970: a potência de cálculo arrancada do Estado, do exército, dos monstros burocráticos que são as grandes empresas e restituída, enfim, aos indivíduos". 63

Um dos grupos, o Home-brew Computer Club, tinha como sócios Steve Jobs e Stephen Wozniac, que fundaram em 1976 a Apple, cujos computadores também foram um dos grandes sucessos entre os computadores pessoais.

O Apple 1 necessitava de um gravador adicional para carregar a linguagem de programação Basic. No Apple 2 a linguagem começou a ser carregada na memória ROM do próprio computador, o que possibilitava "fazer algo com o computador a partir do momento em que fosse ligado". "Além disso, havia uma conexão que permitia usar uma televisão em cores comum como monitor (tela) do computador" (grifos no original). ${ }^{64}$

${ }^{62}$ Cf. LEVY, Pierre, As Tecnologias da Inteligência: o futuro do pensamento na era da Informática, tradução de Les Technologies de L'Intelligence de Carlos Irineu da Costa, Rio de Janeiro, ed. 34, 1993, pp. 43-44.

${ }^{63}$ Idem, ibidem, p. 45.

${ }^{64}$ Idem ibidem, p. 46. 
Anos depois, a Apple, visando a atingir um público mais amplo, integrou novas interfaces aos computadores, que passaram a ser vendidos com uma fonte, um gabinete protetor de plástico rígido e um teclado. Os informatas não perceberam de imediato que o computador estaria se tornando uma mídia de massa.

O panorama do mercado de microcomputadores pessoais ganhou um grande impulso com a entrada da IBM na competição em 12 de agosto de 1981, com o lançamento em Nova York do IBM PC - Personal Computer. Um dos mais importantes fatos que afetaria a indústria da informática nos anos seguintes foi a utilização pela IBM de uma arquitetura aberta, selecionando os componentes básicos e o sistema operacional de fontes externas.

Com a introdução da interface de disquetes abriu-se um campo de uso ilimitado e conexões práticas desconhecidas. Surgiu em 1979 um dos primeiros processadores de texto, o Apple Writter e a primeira planilha, a Visicalc, sem contar os jogos, programas e linguagens de computação que se sucederam.

As interfaces foram sendo sucessivamente agregadas, e os acessos a redes mais vastas foram sendo implementados, alcançando as escolas e os escritórios, que também se redefiniram em função dos microcomputadores: havia se iniciado a "revolução da informática".

A passagem gradual dos aplicativos em ambiente DOS para um novo padrão de ambiente, o do sistema operacional Windows, que se tornou o padrão dominante em aplicativos para computadores pessoais, marcou uma nova era na história dos microcomputadores. O antigo ambiente hostil de um prompt do DOS deu lugar a várias janelas, menus suspensos e telas coloridas, tudo acessível a um clique de um mouse.

Estes recursos tornaram mais amigável o uso de microcomputadores e permitiram que usuários com pouco ou nenhum conhecimento de informática desfrutassem dos recursos de um microcomputador, possibilitando interagir com ele de forma intuitiva e sensório-motora ${ }^{65}$, sem códigos abstratos, democratizando desta forma a utilização dos computadores.

A integração das novas tecnologias de comunicação aos avanços da tecnologia da informação assegurou aos usuários um alto grau de interoperabilidade,

${ }^{65}$ Verbete "sensório-motor": relativo à percepção de impulsos sensoriais e motores. HOUAISS, op. cit. (nota 54). Acesso em 13 de novembro de 2012. 
permitindo-lhes o uso simultâneo de dados, voz, vídeo e som, nos mais variados dispositivos, em um fenômeno denominado "convergência digital".

A convergência pode ser definida como "um processo pelo qual as telecomunicações, a tecnologia da informação e os meios de comunicação, setores que operavam originalmente e em grande parte independentes uns dos outros, estão cada vez mais integrados. O processo está ocorrendo em diferentes níveis, por exemplo, em infraestrutura, dispositivos de usuário final e serviços." 66 Trata-se de um processo de mudança qualitativa, que foi possibilitado pela digitalização total dos conteúdos e pelas redes de banda larga disponibilizadas.

Resultados desta tendência de convergência baseada em inovações nas tecnologias da informação e da comunicação, os dispositivos de usuário final, como smartphone, câmera do telefone, TV interativa e telefonia via Internet, tiveram seus serviços e infraestruturas afetados.

Os telefones celulares, cuja função original era apenas a telefonia, transformaram-se em personal digital assistant (PDA), disponibilizando aplicativos que possibilitam, entre outras funções, ler e enviar e-mails, tirar e enviar fotos, armazenar músicas e vídeos, agendar compromissos, efetuar compras on-line, fazer pagamentos, localizar pessoas e coisas, assistir televisão, entre outras tantas.

Neste contexto, também a televisão tem passado por transformações, tornando-se interativa, já que o processo de convergência modificou o modo de consumo do audiovisual; o consumidor de TV pode utilizar serviços interativos, como televendas ou vídeo-on-demand, a partir de sua casa, através de seus aparelhos.

Desta forma, as diversas interfaces do tipo Windows associadas às tecnologias de comunicação incorporadas a todo tipo de equipamento, aos aplicativos operando com protocolos abertos e à mobilidade dos periféricos (tablet, smartphones, etc.), que os mantêm conectados às grandes redes sem o uso de fios, propiciaram o surgimento de um universo de vida interligado em redes, em que as pessoas acessam e interagem com informações instantaneamente. ${ }^{67}$

A tecnologia dos computadores pessoais, dominada pelo microchip, dobra sua capacidade de armazenamento e velocidade de processamento a cada período de

${ }^{66}$ Cf. STOBBE, Antje, Dawn of Technological Convergence. Deutsche Bank Research. Disponível em: <http://www.dbresearch.com/PROD/DBR INTERNET EN-PROD/PROD0000000000198220.pdf>.

Acesso em 18 de novembro de 2012.

${ }^{67}$ Cf. EMERENCIANO, Adelmo da Silva, op. cit. (nota 39), p. 30. 
12 a 18 meses, e à medida que cresce seu poder, declina seu preço, ampliando o mercado, num círculo virtuoso. ${ }^{68}$

\subsubsection{Internet: a Grande Rede Mundial}

Não restam dúvidas de que os grandes pivôs da história da evolução tecnológica são os computadores e as redes de telecomunicações, responsáveis pela produção, arquivamento e circulação da informação. Mas a grande revolução no mundo dos computadores e das comunicações teve início de fato com o advento da rede mundial de computadores, a Internet. Fruto de uma integração de capacidades, seu surgimento foi possibilitado pelas inúmeras invenções no campo da informática e das comunicações, conforme abordamos; o telégrafo, o telefone, o rádio e os computadores compuseram o cenário para o aparecimento desta infraestrutura de informação e comunicação, que interliga os indivíduos e seus computadores, independentemente de suas localizações geográficas.

Baseada em uma tecnologia de "troca de pacotes" ${ }^{69}$, a Internet teve como embrião um projeto do Departamento de Defesa dos Estados Unidos da América em 1969, sendo concebida como uma rede para interligar computadores geograficamente distantes entre si por meio de um conjunto de protocolos (programas) utilizados em centros de investigação com fins militares. Inicialmente denominado como Advanced Research Projects Agency - Arpanet, o projeto teve sua implementação possibilitada pela extensa rede de telefonia já disponível no território norte-americano. ${ }^{70}$

Os militares, preocupados com a manutenção da rede ativa mesmo em caso de ataque nuclear, optaram por uma concepção de rede sem qualquer centro de controle ou núcleo central que pudesse ser destruído, o que possibilitou o desenvolvimento da rede pela incorporação de múltiplas redes independentes de desenho arbitrário.

${ }^{68}$ Cf. SANTAELLA, Lúcia, op. cit. (nota 25), p. 28.

69 "Nas redes de computadores baseadas nessa técnica, a informação é dividida em pequenas partes (pacotes) antes de ser enviada. Cada pacote carrega o endereço de origem e o de destino, sendo que os pacotes viajam pela rede como unidades independentes de informação, podendo tomar rotas diferentes até o computador de destino, onde são reordenados e checados e a informação é então reconstituída. A comutação de pacotes permite que diversos usuários compartilhem um mesmo canal de comunicação". CARVALHO, Marcelo Sávio Revoredo Menezes, op. cit. (nota 57). Acesso em 19 de novembro de 2012.

${ }^{70}$ Cf. LEINER, Barry M, CERF, Vinton G., CLARK, David D., KAHN, Robert E., KLEINROCK, Leonard, LYNCH, Daniel C., POSTEL, Jon, ROBERTS, Larry G., WOLFF, Stephen, Brief History of the Internet. Disponível em: <http://www.internetsociety.org/internet/internet-51/history-internet/brief-historyinternet>. Acesso em 19 de novembro de 2012. 
A tecnologia de rede foi apresentada ao público em 1972 na Conferência Internacional de Comunicação entre Computadores, em Washington, sendo introduzido neste mesmo ano o correio eletrônico; motivada pela necessidade de um mecanismo de coordenação para os integrantes da equipe que desenvolveu a Arpanet, a aplicação que permitia inicialmente enviar e ler e-mails se tornou a maior aplicação de rede por mais de uma década.

Em 1983, o núcleo estritamente militar da rede foi separado formando a MilNet; com a ligação da Arpanet à recém-criada Computer Science Network - CSNet surgiu a verdadeira Internet, que adotou os protocolos de comunicação TCP/IP. ${ }^{71}$

Haviam sido criadas em 1981 outras duas redes, a Usenet e a BitNet, dedicadas ao conceito de livre acesso a informações e facilidade de utilização. A BITNET - Because It's Time Network foi concebida para interligar pessoas de uma forma simples e barata, conectando inicialmente a Yale University à City University of New York CUNY. Utilizando como tecnologia um software disponível nos computadores IBM das universidades participantes, sua grande atração foi a simplicidade de adesão e operação, diferenciando-se das predecessoras: a Arpanet era restrita às instituições aprovadas pelos militares e a CSNet aos departamentos de ciência da computação. ${ }^{72}$

A comunidade de ensino superior começou a ser interligada de fato com a JANET britânica (1984) e NSFNET EUA (1985). Aliás, a National Science Foundation NSF somente fornecia financiamento para uma conexão à Internet sob a condição de que a conexão fosse disponibilizada a todos os usuários qualificados no centro universitário. ${ }^{73}$

Redes comerciais como a America Online e a CompuServe foram sendo criadas, gerando com sua conexão o que chamamos hoje de Internet. Em 1985, a Internet já se encontrava estabelecida como uma larga comunidade de suporte de pesquisadores e desenvolvedores, começando paulatinamente a ser utilizada para comunicações eletrônicas diárias pelo computador.

${ }^{71} \mathrm{O}$ TCP/IP é um conjunto de protocolos de comunicação entre computadores em rede. Seu nome vem de dois protocolos: o TCP (Transmission Control Protocol - Protocolo de Controle de Transmissão) e o IP (Internet Protocol - Protocolo de Interconexão). O conjunto de protocolos pode ser visto como um modelo de camadas, em que cada camada é responsável por um grupo de tarefas, fornecendo um conjunto de serviços bem definidos para o protocolo da camada superior. Verberte "TPC/IP”, op. cit. (nota 59). Acesso em 19 de novembro de 2012.

${ }^{72}$ Cf. CARVALHO, Marcelo Sávio Revoredo Menezes, op. cit. (nota 57), p. 28. Acesso em 19 de novembro de 2012.

${ }^{73}$ Cf. LEINER, Barry M, CERF, Vinton G., CLARK, David D., KAHN, Robert E., KLEINROCK, Leonard, LYNCH, Daniel C., POSTEL, Jon, ROBERTS, Larry G., WOLFF, Stephen, op. cit. (nota 70). Acesso em 19 de novembro de 2012. 
A ideia chave da Internet como conhecemos hoje é a de uma rede de arquitetura aberta; isto significa que a arquitetura de qualquer rede individual que a ela se incorpore é de livre escolha pelo provedor, o que possibilita sua inclusão em rede com as outras redes pela "Arquitetura de Internetworking". ${ }^{74}$ A convivência das diferentes plataformas no ambiente da Internet só é possível em função do conjunto de protocolos utilizados, o TCP/IP, que são abertos e não patenteados, permitindo implementar uma variedade de plataformas de hardware de computador.

A rápida expansão da Internet nos Estados Unidos durante os anos de 1980 demandou estruturas de coordenação e cooperação entre as várias redes e operadores que iam se integrando. Neste sentido, foram sendo criados organismos que foram se sucedendo ao longo dos anos; os gerentes das entidades mantenedoras da rede associaramse para formar o Federal Research Internet Coordinating Committee (FRICC), um comitê informal para coordenar o apoio governamental ao desenvolvimento e uso da Internet. ${ }^{75}$

Atualmente, uma organização coordenadora mundial, a W3C - World Wide Web Consortium, tem por missão "levar a World Wide Web ao seu potencial máximo, desenvolvendo protocolos e diretrizes que garantam seu crescimento a longo prazo da web". O objetivo da W3C é disponibilizar as "novas possibilidades de comunicação humana, comércio e compartilhamento de conhecimentos" a todas as pessoas, "independente do hardware que utilizam, software, infraestrutura de rede, idioma, cultura, localização geográfica ou capacidade física e mental”. 76

No Brasil, considera-se o marco zero da Internet a primeira reunião realizada em 1987 na Universidade de São Paulo - USP para se discutir o estabelecimento de uma ligação entre computadores e centros de pesquisa, em que participaram membros do governo e da Embratel.

Dois anos depois, em 1989, o Ministério da Ciência e Tecnologia criou a Rede Nacional de Pesquisa - RNP, com o objetivo de construir uma infraestrutura de rede nacional de âmbito acadêmico e disseminar o uso de redes no país. A Internet comercial teve sua abertura no país em 1995, redefinindo o papel da RNP, que estendeu seus serviços

${ }^{74}$ Cf. LEINER, Barry M, CERF, Vinton G., CLARK, David D., KAHN, Robert E., KLEINROCK, Leonard, LYNCH, Daniel C., POSTEL, Jon, ROBERTS, Larry G., WOLFF, Stephen, op. cit. (nota 70). Acesso em 19 de novembro de 2012.

${ }^{75}$ Cf. CARVALHO, Marcelo Sávio Revoredo Menezes, op. cit. (nota 57), p. 33. Acesso em 19 de novembro de 2012.

${ }^{76}$ Disponível em: 〈http://www.w3c.br/Sobre/MissaoW3C >. Acesso em 19 de novembro de 2012. 
de acesso a todos os setores da sociedade. Criou-se então o Centro de Informações Internet/BR, com a função de dar suporte ao surgimento de provedores e usuários da rede. 77

Foi justamente na segunda metade da década de 1990 que ocorreu a grande expansão da Internet, com o desenvolvimento de novos serviços mais amigáveis e eficientes, como o World Wide Web.

Apesar das expressões Internet e World Wide Web (ou Web) serem utilizadas como sinônimos e estarem estreitamente relacionadas, na verdade elas designam coisas distintas. A Internet é a infraestrutura de conexões entre redes, ou seja, o conjunto de meios físicos (que abrange as linhas digitais de alta capacidade, os computadores, roteadores) e os programas utilizados para transportar informações. ${ }^{78}$

Já a World Wide Web (ou Web) é uma das maneiras de acessar e trocar informações através da Internet. Podemos dizer que a Web é um modelo de compartilhamento de informações que utiliza o protocolo HTTP para se comunicar, assim como navegadores (Internet Explorer, Netscape, Mozilla) para acessar as páginas da Web, que são interligadas umas às outras por hiperlinks.

Um aspecto relevante para a disseminação da Internet e, por conseguinte, das tecnologias digitais, foi a disponibilização de "banda larga" em vários países, que se caracteriza "pela disponibilização de infraestrutura de TI que possibilita o tráfego de informações contínuo, ininterrupto e com capacidade suficiente para as aplicações de dados, voz e vídeo". ${ }^{79}$

No início deste século, proliferaram as conexões de empresas e organizações governamentais à Internet, o surgimento do comércio eletrônico, as emissões de rádio (ciberestações) e de diversas outras formas de comunicação interpessoal. ${ }^{80}$

Dados da International Telecommunications Union - ITU, publicados no relatório The Little Data Book on Information and Communication Technology 2012, permitem-nos dimensionar a penetração e abrangência da Internet; segundo a organização,

${ }^{77}$ História da RNP. Disponível em: <http://www.rnp.br/rnp/historico.html $>$. Acesso em 19 de novembro de 2012.

${ }^{78}$ Cf. LEVY, Pierre, op. cit. (nota 60), p. 265.

79 VERAS, Manoel, Cloud Computing: Nova Arquitetura de TI, Rio de Janeiro, Brasport Livros e Multimídia, 2012, p. 10.

80 Cf. Origem e Evolução da Internet. Disponível em <http://profviseu.com/pessoal/formacao/hist.html $>$. Acesso em 19 de novembro de 2012. 
em 2011, 77,86\% da população dos Estados Unidos utilizavam a Internet, ao passo que no Brasil o percentual era de $45 \%{ }^{81}$

Ainda segundo o órgão norte-americano, no mesmo ano, no Brasil, 87\% da população eram urbanas, 34,9\% dos lares possuíam computador e $27,1 \%$ tinham acesso à Internet. O número de telefones celulares no Brasil era de 242,2315 milhões de celulares, muito próximo ao dado norte-americano, de 331,600 milhões de celulares. ${ }^{82}$

O futuro da Internet será debatido pela primeira vez em 25 anos pela comunidade internacional, representada por 193 países, que se reunirão em dezembro de 2012 em Dubai. ${ }^{83}$ No encontro pretende-se definir as regras que irão moldar as telecomunicações nas próximas décadas.

O encontro dividiu o mundo político; a Comunidade Europeia e os Estados Unidos pretendem impedir a imposição de qualquer censura na Internet, mas a China, a Rússia e os países árabes e de outros regimes mais fechados da Ásia trazem a proposta para controlar o conteúdo da internet.

Uma proposta já elaborada de declaração final do encontro inclui a possibilidade de limitação do acesso à Internet e outras formas de comunicação pelos Governos dos países. De modo geral, toda vez que o fluxo de informações na rede mundial representar "interferência em assuntos domésticos de um país, que a soberania de um Estado esteja ameaçada pela informação, por motivos de 'segurança nacional', para proteger a 'integridade territorial' ou simplesmente caso informações de 'natureza sensível forem divulgadas" $" .84$

Os Estados Unidos levarão uma delegação para defender o status quo na gerência da rede, garantindo as empresas norte-americanas que são as que mais lucro têm com a rede. Oficialmente, no entanto, a delegação norte-americana tem a missão de alertar para a formação de uma aliança entre alguns países que, sob argumentos como combate à pedofilia, luta contra spam e outros crimes cibernéticos, visam na verdade a aumentar a censura na Internet.

81 The Little Data Book on Information and Communication Tecnology 2012. International Telecommunications Union - ITU. Disponível em: < $\underline{\text { http://www.itu.int/ITU- }}$ D/ict/statistics/explorer/index.html> . Acesso em 8 de outubro de 2012.

${ }^{82}$ Idem, ibidem. Acesso em 8 de outubro de 2012.

${ }^{83}$ Cf. RONCOLATO, Maurício, O Futuro da Internet nas mãos dos governos em Dubai. O Estado de São Paulo - $\quad$ Economia, Disponível em: $<$ http://www.aasp.org.br/aasp/imprensa/clipping/cli_noticia.asp?idnot=13372 >. Acesso em 30 de novembro de 2012.

${ }^{84}$ Cf. Idem, ibidem. Acesso em 30 de novembro de 2012. 
Outro ponto crítico a ser discutido é o custo de ampliação da infraestrutura da rede, estimado em 800 bilhões de dólares nos próximos cinco anos, custo que é suportado atualmente pelas empresas de telecomunicações. As empresas de telecomunicações pretendem repartir os custos com os maiores usuários da rede, ou seja, os que enviam as maiores quantidades de dados. Estima-se que até 2016 o volume de dados na Internet vai quadruplicar, e aumentará oito vezes no Brasil.

A posição do Brasil no encontro aproxima-se da norte-americana e da dos países europeus, rechaçando qualquer tipo de censura. O Marco Civil da Internet, projeto de lei ainda não aprovado, estabelece os direitos e responsabilidades no uso da rede no Brasil, como o direito ao acesso, à liberdade de expressão e a proibição da discriminação do tráfego de dados, respeitando um dos princípios basilares da Internet: o princípio da neutralidade. 


\section{OS PROBLEMAS JURÍDICO-TRIBUTÁRIOS NO COMÉRCIO ELETRÔNICO}

O advento das modernas tecnologias da informação (TI) e de comunicação (TC) exerceu forte influência nas relações sociais, assim como na forma como se realiza a comercialização de bens e serviços, que passaram a utilizar-se de meios digitais, dando origem à expressão $e$-commerce ou "comércio eletrônico".

O impacto da globalização e da incorporação das tecnologias da informação e da comunicação nas relações comerciais talvez somente possa ser equiparado àquele ocorrido com o advento das grandes navegações, consideradas como o início remoto do processo de globalização ${ }^{85}$, e à invenção da máquina a vapor em 1776.

Os negócios jurídicos desenvolvidos em ambiente eletrônico, através de redes de computadores, são denominados no Brasil "comércio eletrônico". Essa realidade designa tanto operações mercantis quanto operações de prestação de serviços,

85 VALADÃO, Marcos A.P., Uma visão ampliada dos efeitos da globalização no sistema tributário brasileiro, in Revista de Direito Tributário Internacional, ano 4, nº 11, 2009, p. 132. 
relacionando-se à compra e venda de informações, produtos e serviços por meio de redes de computadores. Por meio do "comércio eletrônico" são também transacionados bens intangíveis, que abarcam, por exemplo, serviços de viagem, passagens, software, entretenimento, jogos, músicas, serviços bancários, seguros, serviços de intermediação financeira ou de negócios, serviços ligados à saúde como terapia a distância, cirurgias remotas, serviços de informação. ${ }^{86}$ Portanto, as operações de "comércio eletrônico" englobam, igualmente, todos aqueles serviços não tangíveis, realizados num plano virtual.

Trata-se de uma alteração estrutural que não apenas despoja a transação comercial do contato físico entre os sujeitos envolvidos, mas relativiza as condições de tempo e espaço, inerentes a todos os fatos jurídicos. Pode-se dizer que necessariamente há dois ou mais computadores interligados por algum tipo de rede, em que o produto ou serviço é selecionado, contratado e pago por meios eletrônicos. Os sujeitos podem realizar tais operações a qualquer hora do dia (não há horário de funcionamento como no comércio tradicional) e sem a necessidade de qualquer locomoção ou deslocamento. ${ }^{87}$

Com as conexões possibilitadas por redes de computadores, em especial a rede mundial de computadores World Wide Web - WWW e o desenvolvimento das tecnologias de comunicação, que garantem alta performance às operações, formou-se um “mercado global único" e ininterrupto, que desconhece limites geográficos e horários regulares para a realização das transações comerciais. Neste ambiente o expediente é contínuo, com acessos dos consumidores às empresas em tempo integral, nas 24 horas dos sete dias da semana, em períodos que se alternam em função da origem destes acessos, já que enquanto parte do mundo dorme, o lado oposto encontra-se em plena atividade.

A Internet propicia às empresas acesso relativamente barato a grandes mercados mundiais, dispensando uma infraestrutura física, e até mesmo a mera presença física, o que favoreceu o ingresso das pequenas e médias empresas no cenário do comércio eletrônico, inclusive internacional. Vale dizer, a infraestrutura física cara e a presença física não são mais fatores determinantes para o sucesso de uma empresa, sendo hoje tarefa das mais complexas avaliar ou dimensionar uma empresa em função de sua web page. ${ }^{88}$

${ }^{86}$ Cf. GRECO, Marco Aurelio, Internet e Direito, $2^{\mathrm{a}}$ ed. rev., aum., São Paulo, Dialética, 2000, p. 48.

87 Cf. BRAGHETTA, Daniela de Andrade, Tributação no comércio eletrônico à luz da teoria comunicacional do direito, São Paulo, Quartier Latin, 2003, p. 129.

88 Cf. DOERNBERG, Richard L., Eletronic Commerce and International Tax Sharing, Tax Notes International, Março, 1998. 
A reestruturação promovida pelo "comércio eletrônico" no mercado, além de alterar a maneira de desenvolver as atividades comerciais, tem ainda obrigado as empresas a aperfeiçoarem suas operações, agregando-lhes não apenas tecnologia, mas logística e performance adequadas, já que o mercado passou a contar com players de qualquer local do planeta disputando seus clientes.

\subsubsection{Conceito de Comércio Eletrônico}

O "comércio eletrônico", "subproduto da aceleração vertiginosa das conquistas da tecnologia, projetada sobre o campo das relações mercantis" ${ }^{89}$, foi definido por Alberto Luiz Albertin ${ }^{90}$ como

a realização de toda a cadeia de valor dos processos de um negócio num ambiente eletrônico por meio da aplicação intensa das tecnologias de comunicação e de informação, atendendo aos objetivos de negócios. Os processos podem ser realizados de forma completa ou parcial, incluindo as transações negócio-a-negócio, negócio-a-consumidor e intraorganizacional, numa infraestrutura predominantemente pública de fácil e livre acesso e baixo custo.

Na lição de Fábio Ulhoa Coelho a expressão "comércio eletrônico" denota "a venda de produtos (virtuais ou físicos) ou a prestação de serviços realizadas em estabelecimento virtual. A oferta e o contrato são feitos por transmissão e recepção eletrônica de dados". ${ }^{91}$

Uma visão mais ampla da expressão "comércio eletrônico" era apresentada por Doernberg ainda no final do século passado. Segundo o autor

O termo "comércio eletrônico" se refere ao uso de redes de computadores para facilitar as transações que envolvem a produção, distribuição, venda e entrega de bens e serviços no mercado. Enquanto muitas pessoas associam o comércio eletrônico somente com a compra e venda de informações, bens e serviços através de redes de computadores, os componentes do comércio eletrônico são mais robustos. Comércio eletrônico pode englobar não apenas a simplificação do relacionamento entre consumidores e empresas, mas também os processos de negócio mais eficientes dentro de uma empresa e entre empresas.

${ }^{89}$ CARVALHO, Paulo de Barros, in prefácio de EMERENCIANO, Adelmo da Silva, op. cit. (nota 39), p. 6.

90 ALBERTIN, Alberto Luiz, Comércio Eletrônico: modelo, aspectos e contribuições de sua aplicação, São Paulo, Atlas, $6^{\text {a }}$. ed., p. 3.

${ }^{91}$ COELHO, Fábio de Ulhoa, Curso de Direito Comercial, v. 3, 4 ed. rev., atual, São Paulo, Saraiva, 2003, p. 32. 
Existem muitas e variadas aplicações de comércio eletrônico. Eles incluem a troca de informações eletrônicas de negócios entre servidores corporativos, utilizando o intercâmbio eletrônico de dados (EDI), tecnologia de correio eletrônico (e-mail), boletins eletrônicos e software de conferência, transferências eletrônicas de fundos, e muitas outras tecnologias". ${ }^{92}$

Em estudo sobre o tema, Emerenciano alertou para o uso da expressão “comércio eletrônico" sem qualquer preocupação de precisão terminológica ou científica, própria da linguagem natural. Além da vagueza e ambiguidade próprias da linguagem, a expressão seria fruto de tradução de termo de língua estrangeira (e-commerce), que lhe atribui "conteúdo significativo incerto". ${ }^{93} \mathrm{Na}$ língua inglesa, o termo commerce designa "the activities involved in buying and selling things", ao passo que a expressão e-commerce toma significado mais abrangente, indicando "the business of buying and selling goods and services on Internet". 94.

A expressão inglesa e-commerce, assim como vários termos que apresentam a letra " $\mathrm{e}$ " como prefixo, tais como e-learning, e-business, e-mail, vem de eletrônico (electronic em inglês), ou seja, as palavras que apresentam esta estrutura têm alguma relação com eletrônico, identificando certas atividades no mundo da Internet. ${ }^{95}$

A problemática da tradução de palavras foi estudada por Vilém Flusser, que alertou que as palavras, ainda que sejam traduções, possuem significado distinto em

92 DOERNBERG, Richard L. and Hinnekens, Luc. Electronic Commerce and International Taxation. International Fiscal Association. (The Hague: Kluwer Law International, 1999), p. 45. Apud GODOY, Alexandre de. An Overview of Some Legal Aspects of Eletronic Commerce in Brazil, International Trends and an Approach to the Brazilian Tax on Communication Services". Texto apresentado à Scholl Of Businnes and Public Management da Universidade George Washington, Washington. Washington D.C.: XIV Minerva Program Fall - 2001; pp. 29 e ss. Tradução livre de nossa autoria; no original: "The term 'electronic commerce' refers to the use of computer networks to facilitate transactions involving the production, distribution, sale, and delivery of goods and services in the marketplace. While many people associate electronic commerce with the buying and selling of information, goods, and services over computer networks, the components of electronic commerce are more robust. Not only can electronic commerce embrace the streamlining of the relationship between consumers and business, it also embraces more efficient business processes within a firm and inter-firm. Applications of electronic commerce are many and varied. They include the paperless exchange of business information from business computer to business computer using electronic data interchange (EDI) technology, electronic mail (email), electronic bulletin boards and conferencing software, electronic funds transfers, and many other technologies". Disponível em <http://www.gwu.edu/ ibi/minerva/Fall2001/godoy.alexandre.pdf>. Acesso em 13 de setembro de 2012.

${ }^{93}$ Cf. EMERENCIANO, Adelmo da Silva, op. cit. (nota 39), p. 58.

${ }_{95}^{94}$ Cambridge Advanced Learner's Dictionary, Cambridge University Press, New York, 2008.

95 IDG-Now, e-Commerce, e-Business. e-O que? Disponível em <http://www.ecommerce.org.br/artigos/ecommerce_ebusiness.php>. Acesso em 12 de setembro de 2012. 
cada língua, e, portanto, a tradução é aproximada, concluindo que a legitimidade da tradução é função do parentesco ontológico das línguas. ${ }^{96}$

$\mathrm{Na}$ linguagem comum, a expressão “comércio eletrônico" apresenta diferentes significados, entre os quais Emerenciano relacionou os seguintes: (i) realização de negócios através da rede Internet; (ii) a realização de compras on-line (conectadas a um sistema de transmissão de informações); (iii) a compra e venda de produtos e a prestação de serviços em escala mundial por meio da Internet; (iv) a realização de vendas de produtos e a prestação de serviços a partir de um estabelecimento virtual; e (v) a utilização da Internet como canal mundial de distribuição de bens e serviços. ${ }^{97}$

O próprio termo "comércio", lexicograficamente, reporta-se à atividade de compra, troca ou venda de produtos, mercadorias, ${ }^{98}$ e tem sua origem no latim, commercium, mercancia de com $($ cum $)+$ merx, mercis, mercadoria. ${ }^{99}$ Liga-se, assim, àquelas práticas de intermediação entre produtor e consumidor, com a intenção de obter lucro, que no Brasil desafiam a incidência do imposto sobre circulação de mercadorias, de competência dos Estados, o ICMS.

O “comércio eletrônico", no entanto, envolve não apenas a comercialização de produtos e mercadorias, mas também de serviços tradicionais, além de novas atividades que surgiram justamente em função do desenvolvimento da tecnologia da informação. ${ }^{100}$ Desta forma, o uso da expressão “comércio eletrônico" mostrar-se-ia inadequado para designar toda a gama de atividades por ela abrangidas, que possuiria uma carga semântica adequada em idiomas estrangeiros.

Não obstante, com a evolução das relações econômicas e o surgimento de novas tecnologias, os serviços passaram a ser prestados, em muitos casos, com um caráter comercial, ou "empresarial” como preferiu o Novo Código Civil de 2002. Nos termos do artigo 966 da Lei n 10.406 de 10-1-2002 (Novo Código Civil Brasileiro), “considera-se empresário quem exerce profissionalmente atividade econômica organizada para a

${ }^{96}$ Cf. FLUSSER, Vilém, Língua e Realidade, $2^{\mathrm{a}}$. ed., Anna Blume, 2004, pp. 58-65. Para o autor, somente a língua materna encerra a "verdadeira realidade", o "fundamento firme da realidade".

${ }^{97}$ Cf. EMERENCIANO, Adelmo da Silva, op. cit. (nota 39), p. 58.

${ }^{98}$ Verbete "Comércio" - atividade que consiste em trocar, vender ou comprar produtos, mercadorias, valores etc.; troca de produtos por outros produtos, ou de produtos e serviços por valores, ou de valores por outros valores, visando, num sistema de mercados, ao lucro. Op. cit. (nota 54). Acesso em 13 de setembro de 2012.

99 BUENO, Silveira, Grande Dicionário Etimológico-prosódico da Língua Portuguesa, São Paulo, Saraiva, 1964, 2 volumes.

${ }^{100}$ Cf. BRAGHETTA, Daniela de Andrade, op. cit. (nota 87), p. 70. 
produção ou a circulação de bens ou serviços". O parágrafo único do mencionado artigo exclui do conceito de empresário "quem exerce profissão intelectual, de natureza científica, literária ou artística”. ${ }^{101}$

As novas tecnologias e a crescente demanda da população urbana levaram a prestação de muitos serviços a perder o caráter estritamente pessoal, passando a ser realizada por sociedades organizadas, que desenvolvem suas atividades de forma empresarial. $^{102}$

O Código Civil de 2002 eliminou a anacrônica distinção entre "sociedades civis" (exclusivamente prestadoras de serviços) e "sociedades comerciais", delegando ao conjunto de pessoas (ou mais modernamente à pessoa) que se reúnem para o desenvolvimento de atividades econômicas através de sociedades organizadas a escolha da forma sob a qual irá se estruturar: por meio de "sociedade simples", mantendo seu caráter pessoal ou através de "sociedades empresárias".

Desta forma, podemos concluir que nossa legislação societária deslocou a distinção entre "comércio de mercadorias" e "prestação de serviços" para a distinção entre "caráter pessoal" e "caráter empresarial" das atividades econômicas, que englobam a compra e venda de mercadorias e a prestação de serviços. Com base nesta conclusão, Emerson Drigo propôs um conceito atual para "comércio": "a realização de negócios, com finalidades econômicas, que envolvam a venda e compra de mercadorias ou a prestação de serviços". 103

Ainda que se admita que as palavras polissêmicas possam variar de significado em função do contexto de sua utilização, a expressão "comércio eletrônico" não foi ainda tema de trabalhos científicos ou jurisprudência que tenham construído um novo significado para o signo.

As definições e usos da expressão "comércio eletrônico" têm como foco a natureza do produto negociado, o uso de computadores ou as referências ao espaço onde os negócios se realizam. Fábio Coelho alerta que "o comércio é eletrônico não em razão da natureza do objeto do contrato, mas porque a oferta e a aceitação ocorrem no estabelecimento virtual, ou seja, através da transmissão eletrônica de dados". ${ }^{104}$

${ }^{101}$ Art. 966 da Lei n ${ }^{\circ} 10.406$ de 10-1-2002, Novo Código Civil Brasileiro.

102 Cf. SILVA, Emerson Drigo, Aspecto Espacial da Tributação dos Serviços Prestados por meio da Internet, São Paulo, USP, 2004, pp. 48-50.

${ }^{103}$ Idem, ibidem, p. 50.

${ }^{104}$ COELHO, Fábio de Ulhoa, op. cit. (nota 91), p. 32. 
Juridicamente relevante no "comércio eletrônico", contudo, seria "o fato de que oferta e a aceitação dos contratos se perfazem por transmissão eletrônica de dados e que, em alguns casos, a prestação contratada tem sua execução realizada também por transmissão eletrônica de dados”. 105

Desta forma, Emerenciano propôs em sua obra a substituição da expressão "comércio eletrônico" por "negócio teleinformático", que abrangeria "todo tipo de negócios, quer bens móveis ou imóveis, à prestação de serviços, à cessão de direitos ou ao fornecimento de bens digitais, além de qualquer outro negócio jurídico". ${ }^{106} \mathrm{O}$ "negócio teleinformático" é gênero, do qual são espécies a "contratação teleinformática" e o "negócio virtual".

A "contratação teleinformática" corresponde ao denominado "comércio eletrônico indireto" ou off-line, em que somente a conclusão do negócio jurídico é efetivada por meios digitais. Já o "negócio virtual” designa aquelas transações em que todas as etapas desenvolvem-se em ambiente magnético, de forma virtual, abarcando a contratação, pagamento e o próprio fornecimento de bens digitais, assim como licenças de uso ou utilização remota de softwares e base de dados. ${ }^{107}$

No Brasil encontra-se em tramitação o anteprojeto de Lei n ${ }^{\circ} 1.589 / 99,{ }^{108}$ desenvolvido pela Comissão Especial de Informática Jurídica, da Ordem dos Advogados do Brasil - Seção São Paulo, dispondo sobre o comércio eletrônico e seus principais instrumentos - o documento eletrônico e a assinatura digital. Apesar de não constar na referida norma nenhum conceito ou definição da expressão "comércio eletrônico", o texto evidencia que esta abrange bens, serviços e informações.

Todo o aparato tecnológico significou as seguintes inovações nos negócios jurídicos subjacentes: (i) novas formas de contratação entre ausentes; (ii) a criação e a possibilidade de fornecimento pelas redes de comunicação de bens desapegados

${ }^{105}$ EMERENCIANO, Adelmo da Silva, op. cit. (nota 39), p. 61.

${ }^{106}$ Idem, ibidem, p. 63. Um sistema teleinformático abrange todo o conjunto de equipamentos informáticos e meios de comunicação de dados entre equipamentos distantes uns dos outros.

${ }^{107}$ Cf. Idem, ibidem, p. 64.

${ }^{108}$ Em 30.05.2012, o Projeto de Lei n. 104/2011, que obriga as pessoas jurídicas que comercializem produtos ou serviços pela Internet a informar seu CNPJ e o endereço e telefone de suas instalações físicas, foi apensado ao Projeto de Lei n. 1.589/1999 que, por sua vez, encontra-se apensado ao Projeto de Lei n. 4.906/2001. <http://www.camara.gov.br/proposicoesWeb/fichadetramitacao?idProposicao=16943>. Acesso em $23 \mathrm{de}$ agosto de 2012. 
de uma base física, os bens digitais; e (iii) a possibilidade de operar serviços específicos da rede mundial de computadores (web based service) remotamente. ${ }^{109}$

Não se pode ignorar que a expressão "comércio eletrônico" já incorporou uma carga semântica significativa, que além de ir ao encontro da expressão inglesa que lhe deu origem, parece estar pacificado, em linhas gerais, na doutrina pátria e internacional.

Portanto, para fins do presente trabalho, onde serão estudadas normas do direito internacional relativas ao tema, preservaremos a expressão "comércio eletrônico", com o conteúdo semântico adquirido, significando a realização de negócios, englobando a venda e compra de mercadorias e a prestação de serviços, desenvolvido em ambiente virtual e que se utiliza de redes públicas ou privadas de computadores. ${ }^{110}$

\subsubsection{Características do Comércio Eletrônico}

A principal distinção entre o comércio tradicional e o eletrônico é a irrelevância ou relativização do critério geográfico, visto que este prescinde da presença física das partes para a consecução das operações.

A ausência das clássicas fronteiras físicas supera a ideia de "dentro" e "fora" própria da noção de comércio exterior em relação a uma linha divisória. Segundo Marco Aurélio Greco, "qualquer pessoa, de qualquer lugar do mundo, pode acessar um site na Internet. Isto põe em dúvida onde estará o consumo e qual o tipo de consumidor com o qual os agentes econômicos terão de tratar". ${ }^{111}$ A mobilidade dos agentes econômicos não permite que, ao comprar algo pela Internet, se saiba onde está o fornecedor, já que muitas empresas possuem apenas lugares virtuais identificados por endereços lógicos.

É neste sentido que Schoueri aduz o "declínio" ou a "desmaterialização" do princípio da territorialidade, enquanto ligação com o território, "passando a ser entendido como exigência de uma conexão com o Estado tributante". 112

Em estudo sobre a tributação internacional do "comércio eletrônico" Roberto Vasconcellos elencou as características indissociáveis, mas não exclusivas, deste

${ }^{109}$ EMERENCIANO, Adelmo da Silva, op. cit. (nota 39), p. 61.

${ }^{110}$ Cf. SILVA, Emerson Drigo, op. cit. (nota 102), p. 52.

${ }_{111}^{11}$ GRECO, Marco Aurelio, op. cit. (nota 86), p. 48.

112 SCHOUERI, Luís, Eduardo, Princípios no Direito Tributário Internacional: Territorialidade, Fonte e Universalidade, In Princípios e Limites da Tributação, FERRAZ, Roberto, coordenador, São Paulo, Quartier Latin, 2005, p. 337. 
tipo de operação, dentre as quais evidenciamos: (i) superação das fronteiras e limites geográficos; (ii) dispensa da presença física; (iii) inexistência de limites de horários, podendo ocorrer ininterruptamente por 24 horas, e (iv) eliminação, ou redução significativa, de intermediários. ${ }^{113}$

Podemos diferenciar o "comércio eletrônico" do comércio tradicional na medida em que (i) suas atividades são desenvolvidas de maneira eletrônica, (ii) visando à troca de bens e/ou serviços por meio de instrumentos e técnicas eletrônicas, (iii) utilizando como meio redes de computadores, (iv) cujos negócios envolvem a produção, distribuição, venda e fornecimento de bens e serviços no mercado. ${ }^{114}$

\subsubsection{Espécies de Comércio Eletrônico}

As transações do comércio eletrônico abarcam produtos tangíveis e produtos digitais (intangíveis); aquelas se referem aos produtos e serviços que, apesar de serem viabilizados por meio digital, não prescindem da entrega ou prestação física, enquanto para os bens digitais, o processo pode ser totalmente desenvolvido e concluído de forma eletrônica, sem que haja qualquer contato entre as partes em nenhuma das fases do negócio.

É que no "comércio eletrônico" uma operação pode ser parcial ou completamente realizada por meios eletrônicos; vale dizer, a expressão e-commerce pode designar tanto os instrumentos de comunicação que viabilizam a concretização de transações tradicionais, como aquelas transações cujas operações se viabilizam totalmente por meios eletrônicos, incluindo a própria cessão de bens, sejam estes serviços, direitos autorais ou softwares. ${ }^{115}$

Estas duas formas de ocorrência de comércio eletrônico são classificadas como direta e indireta; se a tradição dos bens não pode ser eletrônica, ou seja, prescinde da entrega física do bem ou da execução presencial do serviço, temos o denominado comércio eletrônico indireto. Por outro giro: neste tipo de comércio os bens e serviços são apenas adquiridos através de canais informáticos, devendo ser expedidos ou

${ }^{113}$ Cf. VASCONCELLOS, Roberto de França, Tributação do Comércio Eletrônico Internacional, São Paulo: USP, 2002, p. 10.

${ }^{114}$ Idem, ibidem, p. 8.

${ }^{115}$ Cf. SCHOUERI, Luís Eduardo, Imposto de Renda e o Comércio Eletrônico, In Internet - O Direito na Era Virtual. SCHOUERI, Luís Eduardo, organizador. 2a . ed. Rio de Janeiro: Forense, 2001, p. 39. 
transportados por serviços postais ou de outra natureza, ou ainda o serviço prestado de forma presencial. Este tipo de transação implica a logística dos produtos, que envolve a aquisição, distribuição, armazenamento e entrega ao cliente, já que no ato em que é formalizada eletronicamente a compra há concomitantemente a contratação de uma empresa de transporte ou de um serviço postal. ${ }^{116}$

Já no comércio eletrônico direto, todas as etapas, os procedimentos da transação, desenvolvem-se em ambiente eletrônico, abrangendo inclusive a entrega eletrônica do bem ou serviço "sem passar por qualquer forma de fronteiras geográficas, ocorrendo a entrega do mesmo sem a necessidade da utilização de serviços postais, como na aquisição de programas de computador ou conteúdos de diversão". ${ }^{117}$ Tal classificação corresponde, respectivamente, à "contratação teleinformática" e ao "negócio virtual", espécies do gênero "negócio teleinformático" proposto por Emerenciano.

Considerando-se os sujeitos envolvidos nas operações do comércio eletrônico, estas se estabelecem em três classes distintas de transações: (i) buniness to business - b2b; (ii) business to consumer - b2c; e (iii) consumer to consumer - $c 2 c$.

Quando as operações desenvolvem-se em um ambiente entre organizações, envolvendo somente empresas denominam-se business to business; já aquelas operações realizadas em um ambiente entre organizações e consumidores, envolvendo estabelecimentos e os consumidores finais são conhecidas como business to consumer. Por fim, quando as partes que negociam não têm cunho empresarial ou de consumo, normalmente figurando apenas como intermediários, as operações denominamse consumer to consumer. ${ }^{118}$

\subsection{Comércio Eletrônico no Brasil - Dados Estatísticos}

O comportamento do mercado eletrônico de compras tem sido estudado no Brasil pela e-bit Informação, com o apoio da Câmara Brasileira de Comércio Eletrônico - Câmara-e-Net, que, objetivando o aprimoramento e desenvolvimento do e-commerce nacional, elabora periodicamente um documento denominado WebShoppers, em que

\footnotetext{
${ }^{116}$ Cf. OLIVEIRA, Julio Maria, op. cit. (nota 27), p. 141.

${ }^{117}$ BRAGHETTA, Daniela de Andrade, op. cit. (nota 87), p. 132 e Cf. EMERENCIANO, Adelmo, op. cit. (nota 39), p. 61.

${ }^{118}$ Cf. VASCONCELOS, Roberto de França, op. cit. (nota 113), p. 18.
} 
analisa a evolução do comércio eletrônico, as mudanças de comportamento do mercado e a preferência dos consumidores. ${ }^{119}$

Tido como referência no mercado nacional de transações eletrônicas, a empresa e-bit colhe informações diretamente dos consumidores das mais de 8 mil lojas virtuais brasileiras, que são utilizadas para monitorar o mercado e auxiliar tanto o consumidor final como as empresas. Neste sentido, gerencia um programa de certificação das lojas virtuais em função de seu desempenho e da aprovação dos consumidores, auxilia na gestão de retenção e fidelização dos "e-consumidores", na publicidade, disponibiliza ferramentas que dimensionam e monitoram as vendas, além de oferecer um serviço de monitoramento de preços, da competitividade e outros direcionados especificamente às transações digitais.

Segundo dados da instituição, no primeiro semestre de 2012, o comércio eletrônico foi responsável pelo faturamento on-line de 10,2 bilhões de reais, que significou um aumento nominal de $21 \%$ em relação ao mesmo período do ano anterior. No período, 29,6 milhões de encomendas foram realizadas nas lojas virtuais, sendo que 5,6 milhões de pessoas fizeram sua primeira compra on-line, totalizando mais de 37,6 milhões de "econsumidores" no Brasil. ${ }^{120}$ Os números são ainda mais significativos se considerarmos que houve no período uma retração de $3,8 \%$ na produção industrial. ${ }^{121}$

As compras concentraram-se nas seguintes categorias: $13 \%$ correspondem a eletrodomésticos, $13 \%$ à saúde, beleza e medicamentos, $11 \%$ à moda e acessórios, $10 \%$ a livros, assinaturas de revistas e jornais e $9 \%$ à informática. Estas compras são classificadas, em função do valor, como tíquete, sendo o valor médio do tíquete brasileiro no mercado interno de 346 reais. O setor projeta um crescimento de $20 \%$ no segundo semestre do ano em relação ao faturamento do primeiro semestre. ${ }^{122}$

119 A empresa e-bit Informação foi criada em 1999 com objetivo de gerenciar informações do comércio eletrônico; atualmente, além de realizar pesquisas sobre hábitos e tendências de e-commerce no Brasil, ainda certifica as lojas e prestadores de serviço em função de seu desempenho no mercado. Segundo dados do site, a empresa reúne hoje mais de 2.500 lojas virtuais conveniadas. Disponível em <http://www.ebitempresa.com.br/>. O Webshoppers encontra-se disponível em 〈http://www.webshoppers.com.br/webshoppers26.pdf $>$. Acesso em 12 de setembro de 2012.

120 Webshoppers e-BIT, $26^{\circ}$ Relatório Semestral de Comportamento do Comércio Eletrônico no Brasil, disponível em: <http://www.e-commerce.org.br/artigos/ecommerce ebusiness.php>. Acesso em $12 \mathrm{de}$ setembro de 2012. Segundo projeções do setor, chegaremos no final de 2012 a um universo de 43 milhões de e-consumidores.

121 Conforme dados do IBGE sobre a produção industrial. Disponível em: 〈http://www.ibge.gov.br/home/estatistica/indicadores/industria/pimpfbr/pim-pf-br_201207caderno.pdf > Acesso em 18 de setembro de 2012.

${ }^{122}$ Op. cit. (nota 120). Acesso em 19 de setembro de 2012. 
No exterior, as transações on-line dos brasileiros têm um valor médio de 158 reais, sendo a empresa BestBuy, norte-americana do ramo de eletroeletrônicos, a primeira colocada em valor de operação (correspondente a 212 reais) e a Amazon a primeira em volume de compras.

A evolução do faturamento do comércio eletrônico é significativa; no primeiro semestre de 2007 o setor faturou 2,6 bilhões de reais, 4,7 bilhões no mesmo período de 2009 e 8,4 bilhões no primeiro semestre de 2011. Ainda segundo pesquisas da e-bit, o fator que mais contribui para a fidelização dos "e-consumidores" são os serviços prestados pelas lojas virtuais brasileiras; embora ainda haja algumas barreiras logísticas que afetam o setor, os "e-consumidores" continuam a realizar suas compras via web movidos por fatores como frete grátis, exíguos prazos de entrega, prazos de pagamento estendidos, entre outros.

Outro segmento de mercado que vem ganhando relevância no $e$ commerce é o das compras coletivas. Apenas no primeiro semestre de 2012 foram vendidos mais de 194 milhões de reais no setor de Hotéis e Viagens, o que equivale a $26,6 \%$ do total do período. Negociado por meio de cupons, o setor mais procurado é o de serviços locais, tais como bares, baladas, restaurantes, entretenimento, cursos e aulas, que faturou apenas na cidade de São Paulo, no primeiro semestre de 2012, 120,5 milhões de reais com a venda de 2,3 milhões de cupons.

Segundo pesquisa da Federação do Comércio de Bens, Serviços e Turismo do Estado de São Paulo - FecomercioSP - divulgada pela e-bit Informação ${ }^{123}$, o faturamento do e-commerce no primeiro semestre de 2010 , de 7,8 bilhões de reais, superou o total de vendas dos Shoppings Centers da Grande São Paulo no mesmo período, que foi estimado em 7,2 bilhões de reais. A entidade realizou pesquisa entre os consumidores paulistanos e concluiu que o e-commerce já atinge mais da metade deles. A $4^{a}$ Pesquisa sobre o Comportamento dos Usuários da Internet, realizada pela FecomercioSP, revela que $62,71 \%$ dos paulistanos têm o hábito de realizar compras pela Internet, o que representa um crescimento de 11,21 pontos porcentuais em relação a 2011.

No segmento educacional, os serviços virtuais também atingem um número cada vez maior de usuários; os dados divulgados pelo Censo da Educação,

${ }^{123}$ A e-bit Informação foi fundada em 1999 para gerenciar informações do comércio eletrônico, e é pioneira na realização de pesquisas sobre hábitos e tendências de $e$-commerce no Brasil. Segundo dados do site, a empresa reúne hoje mais de 2.500 lojas virtuais conveniadas. Disponível em <http://www.ebitempresa.com.br/>. Acesso em 23 de junho de 2012. 
relativos à evolução da graduação à distância, impressionam; nos últimos dez anos o número de matrículas saltou de 5 mil para 930 mil, concentradas nas áreas da educação, ciências sociais e direito. Os usuários deste tipo de serviço têm idade média de 33 anos, e são atraídos pela comodidade, flexibilidade de horário, facilidade de acesso à Internet e pela economia de tempo em eventuais deslocamentos. ${ }^{124}$

O MEC - Ministério da Educação e Cultura detém a competência para regulamentar e avaliar os cursos de graduação presenciais e à distância, que entre outros requisitos deve possuir o mesmo conteúdo programático e disponibilizar atividades presenciais obrigatórias, compreendendo avaliação, estágios, defesa de trabalhos ou prática em laboratório, que devem ser realizadas na sede da instituição ou em polos de apoio presencial. ${ }^{125} \mathrm{O}$ próprio sistema de acompanhamento de processos que regulam a educação superior no Brasil, tais como o credenciamento e recredenciamento de instituições de educação superior e de autorização, reconhecimento e renovação de reconhecimento de cursos superiores é hoje totalmente eletrônico - eMEC, criado com base nas diretrizes do Decreto $\mathrm{n}^{\circ} 5.773$ de 09 de maio de 2006.

\subsection{O Comércio Eletrônico e a Tributação}

$\mathrm{Na}$ medida em que o volume de recursos circulando através das transações efetuadas eletronicamente se multiplica, as implicações tributárias aumentam exponencialmente. Neste cenário, não são apenas as empresas que estão readequando seus procedimentos e revendo suas operações, mas também as Administrações Fazendárias. O fornecimento eletrônico de bens e serviços, que dispensa a presença física e não cria trilhas de auditoria, tem levado os Estados a estudar reformulações em suas políticas fiscais internas e externas, buscando desenvolver regras fiscais racionais e, principalmente, exequíveis.

O problema extrapola as fronteiras nacionais, gerando inquietação e originando debates internacionais sobre o "comércio eletrônico". O tema reacende a

124 Dados do Censo da Educação Superior, realizado pelo MEC. Disponível em: <http://www.ibge.gov.br/projetos/comite_estatisticas_sociais/?page_id=106>. Acesso em 19 de setembro de 2012.

125 Art. 10 do Decreto $n^{\circ} 5.622$, de 19 de dezembro de 2005, com a redação dada pelo Decreto $n^{\circ} 6.303$, de 12 de dezembro de 2007. 
discussão (e a disputa) da tributação no país da fonte e no país da residência que vem de longa data no Direito Tributário Internacional.

No âmbito internacional a mobilidade da renda, que sempre foi a grande preocupação dos Estados, foi acrescida no contexto do "comércio eletrônico" pela mobilidade de consumo e dos agentes econômicos. ${ }^{126}$

\subsection{Comércio Eletrônico Direto: os Bens Digitais}

O avanço tecnológico tem ocasionado aceleradas transformações nas relações mercantis. A evolução tecnológica, em especial das telecomunicações, aniquilou distâncias, criando um novo perfil para o modo de aquisição de bens e serviços.

Entre outras inovações surgem "novos" serviços, desenvolvidos muitas vezes de forma totalmente eletrônica em ambientes virtuais, estando ao alcance de um clique de mouse de seus tomadores, ainda que a milhares de quilômetros destes, desmaterializando quaisquer elementos de conexão considerados pelo princípio da territorialidade.

Neste sentido, nossos tribunais superiores têm sido instados a se manifestar sobre a tributação de institutos jurídicos que não guardam perfeita identidade com aqueles postos na Constituição de 1988, e sobre os quais pleiteiam, entes de diferentes níveis da Federação, o direito de tributar. Assim ocorre com o software e os provedores de Internet, cuja tributação é disputada entre os Estados - por meio do ICMS - e os Municípios - pelo ISS. Contratos complexos como, por exemplo, os de operações de leasing desafiam nossa Corte Constitucional, já que tais operações se compõem de uma série de elementos ou procedimentos que não podem ser cindidos ou facilmente subsumidos a nenhuma daquelas hipóteses previstas originalmente em nossa Carta Magna. 127

Mas não é só; vários "serviços" sofreram transformações em seu processo produtivo, em face da (r)evolução tecnológica e comunicacional, culminando por

${ }^{126}$ GRECO, Marco Aurelio, op. cit. (nota 86), p. 48.

${ }^{127}$ Trecho do voto do Min. Eros Grau, no RE 547.245/SC. Segundo o Supremo Tribunal Federal, o contrato de leasing é contrato autônomo, e que "embora resulte da fusão de elementos de outros contratos, não pode ser considerado como contrato misto, composto por prestações típicas da locação, da compra e de outros contratos, porque tem causa própria e já se tipicizou”. 
criar situações complexas, que desafiam os aplicadores do direito e os Fiscos municipais, já que as condições de tempo e lugar foram relativizadas.

Não estamos nos referindo somente àqueles serviços prestados por meio da Internet, como o envio de respostas a consultoria, de projetos de engenharia, mas a uma gama de serviços surgidos e possibilitados por esta estrutura de comunicação digital, que é o fornecimento, ou uso, de bens digitais. São aqueles "bens que estão presentes no ambiente de rede e cujas respostas ou interações se dão sem qualquer intervenção humana por parte do requisitado (on-line)". ${ }^{128}$

Trata-se da disponibilização de conteúdos ou uso de bens, que são operados e disponibilizados através dos sites, tais como jogos on-line, pesquisa em bancos de dados, consulta a bibliotecas, publicidades, aquisição de filmes, vídeos, músicas ou livros on-line, dentre outros.

Tais operações de fornecimento ou uso de bens digitais são reconhecidas por normas de Direito Positivo de vários países, e em especial na Comunidade Europeia, como prestações de serviço. ${ }^{129}$

O enquadramento decorre, conforme já abordamos, da estrutura do IVA - Imposto sobre Valor Adicionado, adotado por diversos países europeus. A Diretiva 77/388 da Comunidade Europeia ${ }^{130}$ define a abrangência do IVA que incide sobre a “entrega de bens" e sobre a "prestação de serviço", conceituando as expressões respectivamente nos artigos $5^{\circ}$ e $6^{\circ}$ nos seguintes termos:

Operações tributáveis

Artigo $5^{\circ}$

Entregas de bens

1. Por "entrega de um bem" entende-se a transferência do poder de dispor de um bem corpóreo, como proprietário.

2. A energia elétrica, o gás, o calor, o frio e similares consideram-se bens corpóreos.

3. Os Estados-membros podem considerar bens corpóreos:

a) Determinados direitos sobre bens imóveis;

b) Os direitos reais que conferem ao respectivo titular um poder de utilização sobre bens imóveis;

${ }^{128}$ EMERENCIANO, Adelmo da Silva, op. cit. (nota 39), p. 163.

${ }^{129}$ Cf. Idem, ibidem, p. 163

${ }^{130}$ Diretiva $n^{\circ}$ 388/77 da Comunidade Europeia relativa à harmonização das legislações dos EstadosMembros respeitantes aos impostos sobre o volume de negócios - sistema comum do imposto sobre o valor acrescentado. Disponível em: lex.europa.eu/LexUriServ/LexUriServ.do?uri=CELEX:31977L0388:pt:HTML>. Acesso em 23 de setembro de 2012. 
c) As participações e ações cuja posse confira, de direito ou de fato, a propriedade ou o gozo de um bem imóvel ou de uma fração de um bem imóvel.

$[\ldots]$

Artigo $6^{\circ}$

Prestação de Serviços

Por "prestação de serviços" entende-se qualquer prestação que não constitua uma entrega de bens na acepção do artigo $5^{\circ}$.

Essa prestação pode designadamente consistir:

- na cessão de um bem incorpóreo representado ou não por um título;

- na obrigação de não fazer ou de tolerar um ato ou uma situação;

- na execução de um serviço prestado em consequência de ato de

Administração Pública ou em seu nome ou por força de lei.

Ou seja, incidindo o IVA sobre a circulação de bens corpóreos e incorpóreos, a legislação atribuiu a cada uma das categorias uma parte destes definindo seu espectro e a prestação de serviços de forma residual em relação à entrega de bens. Desta forma, foi adotada uma acepção ampla de "prestação de serviços", que engloba, entre outros, as cessões de uso de direitos da propriedade intelectual.

E a legislação dos países que compõem a Comunidade Europeia, como a Itália e a França, refletem tais diretivas; também na Espanha as operações sobre bens digitais relativos a cessões de uso são consideradas prestações de serviço. Desta forma, qualquer cessão de uso de direito sobre a propriedade intelectual contratada por via eletrônica é qualificada como prestação de serviço, considerando-se que a prestação ocorreu no local do estabelecimento do prestador do serviço. ${ }^{131}$

Esta concepção do Direito Positivo estrangeiro sobre os bens digitais tem influenciado alguns doutrinadores nacionais, que defendem a qualificação destes bens como prestações de serviço. ${ }^{132} \mathrm{O}$ recurso ao Direito Comparado deve sempre considerar, no entanto, as peculiaridades específicas de cada ordenamento jurídico, observadas as limitações e as características típicas de cada um dos ordenamentos. ${ }^{133}$

De modo geral, é possível sistematizar os problemas tributários relativos ao comércio eletrônico da seguinte forma: (i) classificação dos produtos telemáticos em bens ou serviços para fins de determinação de seu regime jurídico; (ii) determinação da natureza jurídica do software; e (iii) a identificação do estabelecimento onde ocorreu o fato gerador e do consumidor final.

${ }^{131}$ Cf. EMERENCIANO, Adelmo da Silva, op. cit. (nota 39), p. 164.

${ }^{132}$ Neste sentido, Marcello Martins Motta Filho, Cf. Idem, ibidem, p. 165.

${ }^{133}$ Cf. Idem, ibidem, p. 165. 


\subsubsection{O Regime Jurídico dos Bens}

"Bens", numa acepção econômica, podem ser definidos como "aquelas coisas que, sendo úteis ao homem, existem em quantidade limitada no universo, ou seja, são bens econômicos as coisas úteis e raras, pois só elas são suscetíveis de apropriação". 134

Em nosso ordenamento jurídico, o regime jurídico dos bens é regrado pelo Código Civil Brasileiro, Lei n ${ }^{\circ} 10.406$ de 10 de janeiro de 2002, no Livro II da Parte Geral.

O Código Civil classifica os bens em três classes distintas: (i) bens considerados em si mesmos (bens imóveis e móveis, bens fungíveis e consumíveis, bens divisíveis, bens singulares e coletivos); (ii) bens reciprocamente considerados; e (iii) bens públicos. As classificações distribuem os elementos em classes, a partir de um critério ou método previamente estabelecido, que irá aferir compatibilidade entre os elementos. ${ }^{135}$

O critério aglutinador, eleito para classificar determinados objetos, caso seja inadequado, não correspondendo a quaisquer exigências de ordem prática, resultará numa classificação com pouca ou nenhuma importância. Ademais, leciona Paulo Ayres que toda classificação jurídica "deve refletir as peculiaridades do direito positivo". ${ }^{136}$

Além das classificações abrangidas pelo Código Civil, a doutrina adota a classificação oriunda do Direito Romano que distribui todos os bens em dois grandes grupos: o das coisas corpóreas e o das coisas incorpóreas. Os bens aglutinados em uma determinada categoria atraem "certos princípios que permitem fixar, de maneira genérica, a forma como a lei os trata e quais as relações jurídicas que despertam”. ${ }^{137}$

Esta classificação ganha relevância prática nestes tempos de arquivos digitais e redes virtuais, em função da distinção do modo de transmissão destes bens: as coisas corpóreas se transferem pela tradição, como a compra e venda, pela doação, etc., e os bens incorpóreos pela cessão. ${ }^{138}$

\footnotetext{
${ }^{134}$ RODRIGUES, Silvio, Direito Civil, volume 1, São Paulo, Saraiva, 33a . ed., 2003, p. 115.

${ }^{135}$ Cf. BARRETO, Paulo A., Contribuições: Regime Jurídico, Destinação e Controle, Noeses, 2006, p. 49.

${ }^{136}$ Idem, ibidem, p. 51.

${ }^{137}$ PEREIRA, Caio Mário da Silva, Instituições de Direito Civil, São Paulo, Forense, 20ª ed., vol. 1, p.405.

${ }^{138}$ Cf. Idem, ibidem, pp. 405-409. O critério de classificação no Direito Romano era a tangibilidade ou possibilidade das coisas serem ou não tocadas.
} 
Os Códigos modernos deixaram de prescrever princípios legais específicos relativos a esta classificação que, como já advertia Teixeira da Silva, desatende a uma orientação lógica. ${ }^{139}$ Para o referido autor, a classificação isolava de uma parte a coisa, como objeto material sobre a qual recai o direito, abstraindo, contudo, do próprio direito, e do outro lado são dispostos os direitos sem considerar o objeto dos direitos reais.

No entanto, as relações jurídicas podem ter por objeto uma coisa de existência material ou abstrata; assim, para certos direitos que se aproximam da propriedade, mas que a rigor não podem ser classificados como "direitos dominiais", a técnica moderna reserva a expressão "propriedade", acrescida do qualificativo “incorpórea", e refere-se tanto em doutrina como na lei, à "propriedade incorpórea". ${ }^{140}$

Desta forma, por exemplo, o direito do autor sobre sua obra é qualificado como "propriedade literária, científica e artística"; o direito de explorar uma patente de invenção ou uma marca de fábrica como "propriedade industrial".

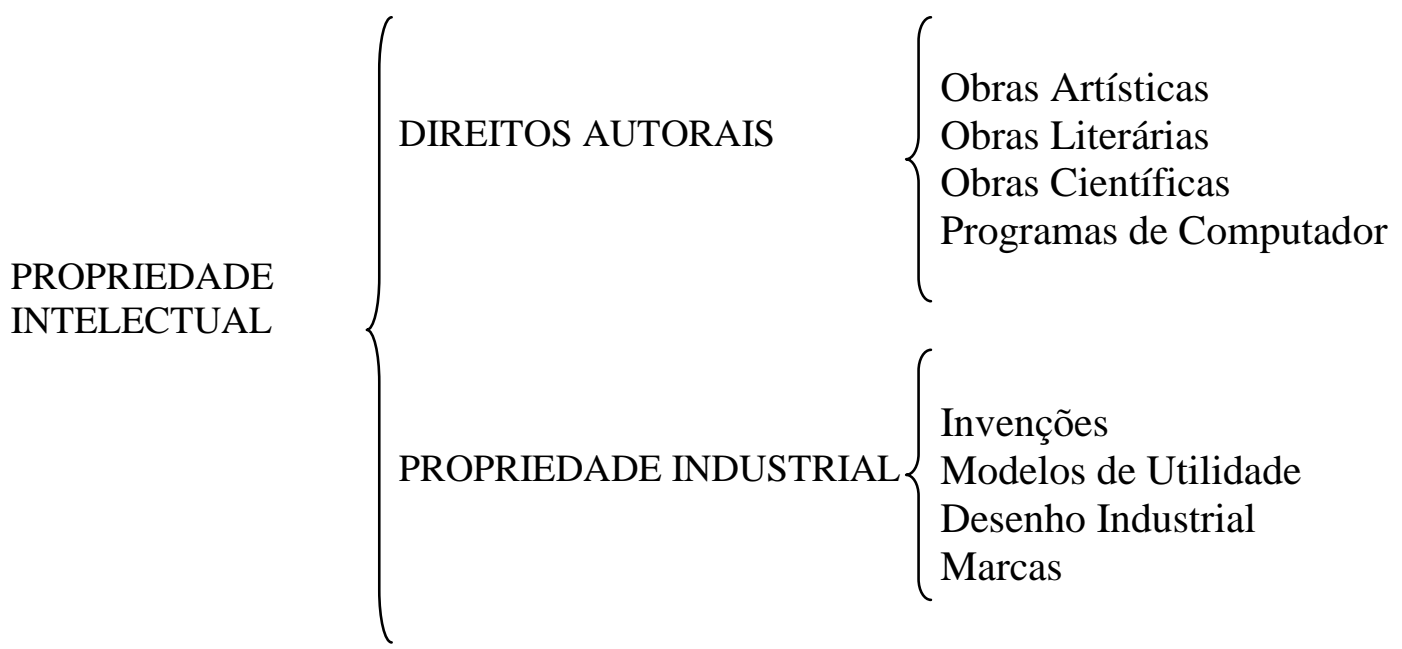

Genericamente denominados como "propriedade intelectual", estes direitos são tutelados pelo direito positivo, sendo disciplinados por legislações esparsas específicas; a Lei n ${ }^{\circ} 9.279$ de 14 de maio de 1996 regula os direitos e obrigações relativas à propriedade industrial; a Lei ${ }^{\circ} 9.610$ de 19 de fevereiro de 1998 consolida a legislação sobre direitos autorais e a Lei ${ }^{\circ} 9.609$ de 18 de fevereiro de 1998 dispõe sobre a proteção da propriedade intelectual de programa de computador e sua comercialização no país.

${ }^{139}$ Cf. PEREIRA, Caio Mário da Silva, op. cit. (nota 137), p. 406.

${ }^{140}$ Idem, ibidem, p. 83. 
Todo sistema informático é constituído por duas partes: uma física e uma intelectual, que possuem tutelas jurídicas distintas. O conjunto dos elementos materiais, denominado internacionalmente de hardware, é juridicamente amparado pela proteção à propriedade industrial. Já a parte intelectual, internacionalmente designada como software, é composta pelos comandos e instruções necessários à realização de diversas tarefas, e sua tutela jurídica advém da proteção dos direitos autorais. ${ }^{141}$

A Lei $\mathrm{n}^{\circ} 9.609$, de proteção da propriedade intelectual de programa de computador, faz expressa remissão em seu artigo $2^{\circ}$ ao regime conferido às obras literárias pela legislação de direitos autorais e conexos vigentes no país, que, desta forma, aplicamse aos programas de computador; vale dizer, além das disposições específicas da "Lei do Software", aplicam-se ainda à propriedade intelectual de programa de computador as disposições relativas aos direitos autorais constantes na Lei ${ }^{\circ} 9.610$.

A caracterização dos programas de computador no rol das obras literárias, com sua inclusão no regime jurídico de proteção aos direitos autorais é uma tendência internacional. A partir dos anos de 1970, quando os softwares começaram a ser comercializados de forma independente, e não como meros acessórios dos computadores, adquirindo existência econômica própria, foram paulatinamente sendo retirados do regime jurídico de proteção à propriedade industrial conferido ao hardware e inseridos no regime jurídico de proteção aos direitos autorais. ${ }^{142}$

Os Estados Unidos foram um dos primeiros países a elaborar leis próprias de proteção ao software (copyright) em 1980, elegendo o regime do direito de autor, amparado por algumas regras específicas para sua comercialização. No Brasil, a Lei $\mathrm{n}^{\circ} 7.646$ de 1987 introduziu no ordenamento jurídico brasileiro a proteção ao programa de computador, conferindo-lhe o mesmo regime jurídico de proteção conferido às obras literárias.

O TRIPS ${ }^{143}$, acordo internacional sobre proteção industrial, prevê em seu artigo $10, \S 1^{\circ}$ a proteção como obra literária aos programas de computador, na forma da Convenção de Berna (1971), dos quais o Brasil é signatário. ${ }^{144}$

${ }^{141}$ Cf. POLI, Leonardo Macedo, Direitos de Autor e Software, Belo Horizonte, Del Rey, 2003, pp. 8-9.

${ }^{142}$ Cf. Idem, ibidem, pp. 20- 21.

143 Juntamente à criação da Organização Mundial do Comércio - OMC no âmbito do GATT - General Agreement on Tariffs and Trade, criou-se também, relativamente à propriedade intelectual, como anexo (Annex 1C) o Trade Related Aspects of Intellectual Property Rights - TRIPs, aprovado em Marrakesh, em 1994. O acordo sobre aspectos dos Direitos de Propriedade Intelectual relacionados ao comércio (Agreement on Trade Related Aspects of Intellectual Property Rights - TRIPs), que é um dos pilares da 
A definição de "programa de computador" é veiculada pelo artigo $1^{\circ}$ da Lei ${ }^{\circ} 9.609$, denotando que o legislador vislumbrou a necessidade de aclarar o significado da expressão, para com isso reduzir as incertezas. É a denominada "definição estipulativa", ou legal, a que já nos referimos, que firma o significado de uma expressão utilizada em um texto normativo, institucionalizando seu conteúdo. Vejamos seu teor:

Programa de computador é a expressão de um conjunto organizado de instruções em linguagem natural ou codificada, contida em suporte físico de qualquer natureza, de emprego necessário em máquinas automáticas de tratamento da informação, dispositivos, instrumentos ou equipamentos periféricos, baseados em técnica digital ou análoga, para fazê-los funcionar de modo e para fins determinados. ${ }^{145}$

Com base nesta definição, Emerenciano concluiu que os "bens digitais" constituem softwares sem suporte tangível. A necessidade de um "suporte físico de qualquer natureza", contida na definição, não invalidaria tal interpretação, já que haveria "uma forma de existência corpórea qualquer para os bens digitais, mas tão-somente sua intangibilidade direta pelos sentidos humanos". ${ }^{146}$ Desta forma, ainda que os sinais digitais não possam ser sentidos ou percebidos pelos sentidos humanos, exigem um "intérprete" mediato que os decodifique para apresentá-los de forma que nos seja perceptível.

Parece-nos que é possível afirmar que todo software é um bem digital, no entanto, o contrário não é verdadeiro. O software constitui um conjunto organizado de instruções, expresso em algoritmos, características que não são inerentes a todo bem digital. Algoritmo são instruções que determinam um comportamento a ser executado por um dispositivo, como computador ou tablet.

Um filme obtido por meio de download é, sem dúvida, um bem digital; no entanto, trata-se apenas de um conjunto de dados digitais que para serem visualizados

OMC, inseriu no sistema multilateral de comércio a proteção dos direitos de Propriedade Intelectual, tendo como escopo a uniformização de regras relativas a essa área e a harmonização da proteção por meio de padrões mínimos que deveriam ser adotados por todos os seus membros. O TRIPS foi ratificado pelo Brasil pelo Decreto n ${ }^{\circ} 1.355$ de 30.12.1994. Cf. CRETELLA NETO, José, Do Contrato Internacional de Franchising, Rio de Janeiro, Forense, 2000, pág. 74.

${ }^{144}$ Em 1886, foi assinada na cidade suíça de Berna uma convenção reconhecendo o direito do autor entre as nações, sendo conhecida como Convenção de Berna. Atualmente, quase todas as nações signatárias são membros da Organização Mundial do Comércio (OMC), e em abril de 2012 eram 165 os países signatários da Convenção. Disponível em: 〈http://www.wipo.int/treaties/en/documents/pdf/berne.pdf $>$ Acesso em 9 de novembro de 2012.

145 Art. $1^{\circ}$ da Lei $\mathrm{n}^{\circ}$ 9.609, de 18 de fevereiro de 1998.

${ }^{146}$ EMERENCIANO, Adelmo da Silva, op. cit. (nota 39), p. 83. 
necessitam de um dispositivo digital (computador, tablet, celular) e um plug-in ${ }^{147}$ ou software que o "interpreta" e disponibiliza as imagens. Vale dizer, os sinais digitais exigem um intérprete mediato para decodificá-los e apresentá-los de maneira perceptível aos sentidos humanos, funcionando o computador (ou tablet, celular), desta forma, como um “intérprete cibernético". 148

Segundo Lévy, "o armazenamento em memória digital é uma potencialização, a exibição é uma realização". Desta forma, a maior parte dos programas contidos nos dispositivos computacionais são máquinas de exibir (realizar) mensagens, sejam elas imagens, textos, etc. ${ }^{149}$

Importante ressaltar que, caso o dispositivo (computador, tablet ou celular) não possua determinado programa específico para a "realização" do arquivo digital, não será possível, por exemplo, visualizar uma fotografia, um livro ou um filme, etc. Repositórios como os CDs e os DVDs armazenam arquivos digitais, constituídos por uma sequência de bits, que são os signos que os representam em linguagem de sobrenível, que não possuem capacidade ou comandos específicos para autorreprodução.

Os softwares ou programas de computador, em termos semióticos, considerando-se a relação dos signos em si mesmos no seu modo de ser, aspecto ou aparência, representam natureza de lei ou hábitos, classificando-se como "legi-signos" 150. $\mathrm{E}$ os arquivos de filmes, livros ou fotos digitais, na medida em que representam por similaridade os objetos físicos, reais e materiais correspondentes, classificam-se como "ícones".

Tal distinção alicerça nossa classificação dos "bens digitais" em gênero do qual são espécies distintas: (i) softwares, que abrangem programas-fonte, programasobjeto, aplicativos para celulares e smartphones, entre outros, tutelados pelas normas pertinentes à propriedade intelectual de programa de computador, e (ii) arquivo de obra

${ }^{147}$ Plugin ou módulo de extensão (também conhecido por plug-in, add-in, add-on) é um aplicativo utilizado para adicionar funções a outros programas já instalados, provendo alguma funcionalidade nova ou muito específica. Podem ainda ser aplicativos que, adicionados aos browsers de Internet, possibilitam a visualização de diferentes tipos de conteúdo (vídeos, áudio, etc.). Op. cit. (nota 59). Acesso em 2 de outubro de 2012.

${ }^{148}$ EMERENCIANO, Adelmo da Silva, op. cit. (nota 39), p. 83.

${ }^{149}$ LEVY, Pierre, op. cit. (nota 48), p. 40.

${ }^{150} \mathrm{Na}$ Semiótica peirceana os signos foram classificados em dez tricotomias ou divisões triádicas do signo, de cuja combinatória resultam 64 classes de signos. Dentre estas tricotomias, há três principais, às quais ele dedicou observações detalhadas. Estas classes se estabelecem da seguinte forma: tomando-se a relação do signo consigo mesmo (Quali-signo, Sin-signo, Legi-signo), a relação do signo com seu objeto dinâmico (Ícone, Índice, Símbolo) e a relação do signo com seu interpretante (Rema, Dicente, Argumento). Cf. SANTAELLA, Lúcia, op. cit. (nota 31), pp. 96-97. 
digital, que engloba filmes, fotos, livros e outras obras digitais, cujos direitos dos autores são tutelados como "propriedade literária, científica e artística".

Os primeiros caracterizam-se por encerrar instruções para a operação de um computador ou dispositivo similar, com a finalidade de se obter um resultado. Já os arquivos de obras digitais são meros agrupamentos de bits, armazenados em um repositório, que demandam um dispositivo computacional para serem lidos, visualizados ou acessados.

Juridicamente a proteção às duas classes de bens digitais é análoga, já que a Lei $\mathrm{n}^{\circ} 9.609$, que protege a propriedade intelectual de programa de computador, ao dispor o regime de proteção destes bens, faz remissão expressa aos dispositivos da Lei ${ }^{\circ}$ 9.610, que tutela os direitos autorais.

\subsubsection{O Regime Jurídico aplicável aos Bens Digitais}

\section{Os "bens digitais" foram conceituados por Emerenciano como}

conjuntos organizados de instruções, na forma de linguagem de sobrenível, armazenados em forma digital, podendo ser interpretados por computadores e por outros dispositivos assemelhados, que produzam funcionalidades predeterminadas. Possuem diferenças específicas tais como sua existência não-tangível de forma direta pelos sentidos humanos e seu trânsito por ambiente de rede teleinformática, uma vez que não se encontram aderidos a suporte físico. ${ }^{151}$

No entanto, considerando a classificação proposta neste trabalho para os "bens digitais" em softwares e obras digitais, ambos abrangidos pelo regime jurídico do Direito Autoral, disciplinado na Lei $\mathrm{n}^{\circ}$ 9.609, entendemos que o conceito de "bens digitais" deve ser mais abrangente, considerando também as características inerentes às obras digitais.

Destarte, tomaremos um conceito mais genérico para "bens digitais", considerando-os como conjuntos organizados de dados na forma de linguagem de sobrenível, armazenados na forma digital, que podem constituir-se em instruções e devem ser interpretados por dispositivos específicos que possuam funcionalidades predeterminadas.

${ }^{151}$ Cf. EMERENCIANO, Adelmo da Silva, op. cit. (nota 39), p. 83. 
As Leis $\mathrm{n}^{\circ} 9610$ e $\mathrm{n}^{\circ} 9.609$, que tutelam respectivamente os direitos autorais e de propriedade intelectual sobre software, encontram fundamento de validade na Constituição Federal, no art. 5 , inciso XXVII, que assegura aos autores "o direito exclusivo de utilização, publicação ou reprodução de suas obras, transmissível aos herdeiros pelo tempo que a lei fixar".

Esta proteção conferida por nosso ordenamento jurídico é fundamental em função da própria natureza destes bens; ao contrário dos bens corpóreos que existem em quantidade limitada e têm como atributo o exclusivismo, que retira o bem da sociedade, a propriedade dos bens incorpóreos vale por sua exploração, que supõe a formação e conservação de uma clientela. Como pode ser utilizado por um número indefinido de pessoas, este deve ser protegido, já que com a exploração concorrente ou predatória há o risco de perder-se a coisa em si. ${ }^{152}$

A "propriedade intelectual" é gênero da espécie "propriedade industrial" e pode ser conceituada como o "conjunto de direitos relacionados à criação do espírito humano, constituindo componente essencial do comércio em geral". ${ }^{153}$ Vale dizer, corresponde ao direito que o titular detém sobre bens imateriais, frutos da intelectualidade humana.

Para a Associação Brasileira da Propriedade Intelectual (ABPI), a propriedade intelectual compreende o direito da propriedade industrial, autoral, da concorrência e a transferência de tecnologia, bem como de outros ramos do direito relativos ou afins. ${ }^{154}$

Desta forma, a "propriedade intelectual" abarca o direito autoral e a propriedade industrial, numa referência à sua imaterialidade e à origem comum (o intelecto humano). O direito autoral tutela as obras artísticas, literárias, científicas e os programas de computador e possuem natureza declaratória, sendo que o direito de exclusividade do criador da obra ou do programa de computador decorre da própria criação, bastando apenas a prova da anterioridade.

O fundamento da proteção jurídica outorgada às criações intelectuais já encerrou diversas teorias, sendo mais relevante a teoria de que esta proteção seria um corolário do direito de personalidade. Atualmente, a justificativa prevalente sobre o

\footnotetext{
152 RIPERT, Georges, Apud LEONARDOS, Gabriel Francisco, Tributação da Transferência de Tecnologia, Rio de Janeiro, Forense, 1997, pág. 69.

${ }^{153}$ Cf. CRETELLA NETO, José, op. cit. (nota 143), pág. 71.

${ }^{154}$ Disponível em: 〈http://www.abpi.org.br/estatutoseregimentos.asp >. Acesso em 25 de setembro de 2012.
} 
assunto é que a proteção à propriedade imaterial baseia-se no princípio de repressão à concorrência desleal, ou seja, visa a vedar o uso fraudulento no desvio da clientela alheia. $^{155}$

A Diretiva 2001/29/CE do Parlamento Europeu e do Conselho, de 22 de Maio de 2001, relativa à harmonização de certos aspectos do direito de autor e dos direitos conexos na sociedade da informação, considera que a proteção jurídica a tais direitos contribui para a manutenção e o desenvolvimento da atividade criativa, no interesse dos autores, dos intérpretes ou executantes, dos produtores, dos consumidores, da cultura, da indústria e do público em geral. Além disto, fundamenta-se na premissa de que "uma maior segurança jurídica estimulará consideravelmente os investimentos na criatividade e na inovação, nomeadamente nas infraestruturas de rede, o que, por sua vez, se traduzirá em crescimento e num reforço da competitividade da indústria europeia". ${ }^{156}$

O autor de uma obra intelectual exerce sobre ela direitos de caráter intelectual que não se incluem nas categorias de direitos reais, havendo uma completa dissociação entre a criação em si e o objeto em que se concretiza. No entanto, para que haja a proteção à criação intelectual, esta deve ser exteriorizada, compondo o mundo físico sob alguma forma perceptível aos sentidos humanos. ${ }^{157}$

Os direitos patrimoniais oriundos do direito intelectual resultam da utilização econômica da obra, com a exploração econômica sob qualquer modalidade, e cabem exclusivamente ao autor, que tem o direito de utilizar, fruir e dispor da obra, nos termos do disposto no art. 28 da Lei, podendo explorá-la por diversas maneiras. Os softwares, apesar de serem tutelados juridicamente como direitos autorais, estão sujeitos ainda ao registro, que protege a forma pela qual a ideia foi exteriorizada e apresentada, possuindo neste caso mero efeito declaratório. ${ }^{158}$

Nos termos do disposto na legislação de regência, os direitos autorais são considerados "bens móveis" (art. $3^{\circ}$ da Lei $\mathrm{n}^{\circ}$ 9.610) e possuem cunho patrimonial, posto que passíveis de "distribuição" (inciso IV do art. $5^{\circ}$ da Lei n 9.610), que compreende a disponibilização do público do original ou cópia de obras literárias, artísticas ou científicas,

\footnotetext{
${ }^{155}$ Cf. LEONARDOS, Gabriel Francisco, op. cit. (nota 152), p. 69.

156 Diretiva 2001/29 da Comunidade Europeia. Disponível em: < $\underline{\text { http://eur- }}$ lex.europa.eu/LexUriServ/LexUriServ.do?uri=CELEX:32001L0029:PT:HTML>. Acesso em 3 de outubro de 2012.

${ }^{157}$ Cf. EMERENCIANO, Adelmo da Silva, op. cit. (nota 39), p. 86.

${ }^{158}$ Cf. Idem, ibidem, p. 87.
} 
interpretações ou execuções fixadas e fonogramas, mediante a locação ou qualquer outra forma de transferência de propriedade ou posse.

A Lei de Direitos Autorais concede ao autor da obra (ou do software) dois tipos de direitos: os morais e os patrimoniais. Nos termos do art. 24 da norma em epígrafe, constituem direitos morais do autor:

I - o de reivindicar, a qualquer tempo, a autoria da obra;

II - o de ter seu nome, pseudônimo ou sinal convencional indicado ou anunciado, como sendo o do autor, na utilização de sua obra;

III - o de conservar a obra inédita;

IV - o de assegurar a integridade da obra, opondo-se a quaisquer modificações ou à prática de atos que, de qualquer forma, possam prejudicá-la ou atingi-lo, como autor, em sua reputação ou honra;

$\mathrm{V}$ - o de modificar a obra, antes ou depois de utilizada;

VI - o de retirar de circulação a obra ou de suspender qualquer forma de utilização já autorizada, quando a circulação ou utilização implicarem afronta à sua reputação e imagem;

VII - o de ter acesso a exemplar único e raro da obra, quando se encontre legitimamente em poder de outrem, para o fim de, por meio de processo fotográfico ou assemelhado, ou audiovisual, preservar sua memória, de forma que cause o menor inconveniente possível a seu detentor, que, em todo caso, será indenizado de qualquer dano ou prejuízo que lhe seja causado.

Ressalte-se que, até mesmo com a morte do autor transmitem-se a seus sucessores os direitos previstos nos incisos I a IV.

Os direitos patrimoniais sobre a obra ou programa de computador, que se constituem nos direitos exclusivos de utilizar, fruir e dispor da obra literária, artística ou científica, são independentes e comportam diversas modalidades de utilização, também autônomas. Desta forma, a autorização concedida pelo autor, ou pelo produtor, respectivamente, para qualquer forma de utilização não se estende a quaisquer das demais. 159

A reprodução é uma das modalidades de uso mais relevantes para os "bens digitais", conceituada no inciso VI do art. $5^{\circ}$ da norma em apreço:

Art. $5^{\circ}$. Para os efeitos desta lei, considera-se:

$[\ldots]$

VI - reprodução - a cópia de um ou vários exemplares de uma obra literária, artística ou científica ou de um fonograma, de qualquer forma tangível, incluindo qualquer armazenamento permanente ou temporário por meios eletrônicos ou qualquer outro meio de fixação que venha a ser desenvolvido. 
A circulação econômica de "bens digitais" se dá pelo direito de reprodução, que é uma das formas pelas quais o autor disponibiliza sua obra ao público, na forma, local e pelo tempo que desejar, a título oneroso ou gratuito; a utilização da obra depende sempre, por quaisquer modalidades, da autorização prévia e expressa do autor. Essa é a dicção dos artigos 29 e 30 da Lei n ${ }^{\circ} 9.610$.

A Lei de Direitos Autorais prevê expressamente no art. 37 que a aquisição de um exemplar, ou mesmo do original de uma obra protegida, não confere ao adquirente os direitos patrimoniais inerentes ao autor, ressalvando as convenções contratuais em contrário e as exceções previstas naquela Lei.

As obras literárias podem ainda circular economicamente pela distribuição mediante cabo, fibra ótica, satélite, ondas ou qualquer outro sistema que permita ao usuário realizar a seleção da obra ou produção para percebê-la em um tempo e lugar previamente determinados por quem formula a demanda, e nos casos em que o acesso às obras ou produções se faça por qualquer sistema que importe em pagamento pelo usuário, assim como a inclusão em base de dados, o armazenamento em computador, a microfilmagem e as demais formas de arquivamento do gênero; essa é a dicção dos incisos VII e IX do art. 29.

Os bens digitais, sejam eles softwares de computadores ou arquivos de obra digital, podem constituir-se em objetos de variados negócios jurídicos. Todos os bens digitais possuem natureza jurídica de obra intelectual, e seus direitos patrimoniais podem ser explorados economicamente por meio de licença de uso, locação ou cessão, conforme previsto no art. 49 da Lei de Direitos Autorais:

Art. 49. Os direitos de autor poderão ser total ou parcialmente transferidos a terceiros, por ele ou por seus sucessores, a título universal ou singular, pessoalmente ou por meio de representantes com poderes especiais, por meio de licenciamento, concessão, cessão ou por outros meios admitidos em Direito [...] (g.n.)

Em que pese a Lei ${ }^{\circ}$ 9.609/98 listar a compra e venda como modalidade de transferência de cópia de software, a impropriedade deve ser reputada à atecnia do legislador. Os direitos intelectuais não podem ser objeto de venda, vez que o direito do autor é sobre a criação e utilização da obra e não sobre um corpus mechanicum que possa 
exteriorizá-lo. Desta forma, vários direitos do autor, assim como o do autor-desenvolvedor do software, não são alienáveis. ${ }^{160}$

Este é o motivo pelo qual as leis de proteção aos direitos autorais e ao software tutelam o uso destes bens digitais. Nos termos das referidas normas, tais bens podem ter seus direitos comunicados pelo próprio autor, por meio das seguintes modalidades: (i) "cessão dos direitos de comercialização" (art. $8^{\circ}$ da Lei 9.609/98) ${ }^{161}$; (ii) licença de uso (art. $9^{\circ}$ da Lei 9.609/98) ${ }^{162}$ e (iii) locação (art. $2^{\circ}$, § $5^{\circ}$ da Lei 9.609/98). ${ }^{163}$ Esta é também a dicção do art. 49 da Lei n ${ }^{\circ}$ 9.610/98 que alude à transferência dos direitos do autor por meio de (i) licenciamento, (ii) concessão, (iii) cessão e outros meios admitidos em Direito.

\subsubsection{Da Licença de Uso}

O contrato de licença de uso é inerente à fruição dos bens imateriais, que admitem utilização simultânea por um número ilimitado de pessoas; por intermédio deste contrato "o titular dos direitos de autor autoriza outra pessoa, mediante remuneração e conservando para si a propriedade intelectual, a utilizar programa" ou arquivo de obra. ${ }^{164}$

Por outro giro, consiste o contrato de licença de uso na concessão ao licenciado do direito de exploração do objeto, nos termos do avençado, observadas as restrições previstas na lei, preservando o licenciador a titularidade sobre o bem ou sobre a obra.

A finalidade deste contrato é satisfazer às necessidades do licenciado, que, no entanto, recebe somente uma permissão para o uso do bem, de forma não exclusiva, sendo-lhe defeso transferir a outrem, comercializar, doar, arrendar, alienar, sublicenciar e tampouco dar o objeto (ou o bem) em garantia. Vale dizer, há uma obrigação

${ }^{160}$ Cf. EMERENCIANO, Adelmo da Silva, op. cit. (nota 39), p. 93.

${ }^{161}$ Lei n ${ }^{\circ} 9.609 / 98$ - Art. $8^{\circ}$ "Aquele que comercializar programa de computador, quer seja titular dos direitos do programa, quer seja titular dos direitos de comercialização, fica obrigado, no território nacional, durante o prazo de validade técnica da respectiva versão, a assegurar aos respectivos usuários a prestação de serviços técnicos complementares relativos ao adequado funcionamento do programa, consideradas as suas especificações".

${ }^{162}$ Lei n ${ }^{\circ} 9.609 / 98$ - Art. $9^{\circ}$ "O uso de programa de computador no País será objeto de contrato de licença”.

${ }^{163}$ Idem - Art. $2^{\circ}, \S 5^{\circ}$ "Inclui-se dentre os direitos assegurados por esta Lei e pela legislação de direitos autorais e conexos vigentes no País aquele direito exclusivo de autorizar ou proibir o aluguel comercial, não sendo esse direito exaurível pela venda, licença ou outra forma de transferência da cópia do programa.

${ }^{164}$ CEZAROTI, Guilherme, ICMS no Comércio Eletrônico, São Paulo, MP Editora, 2005, p. 101. 
contratual de "não fazer" para o licenciado, inerente ao contrato de licença, que consiste no em estar impedido de copiar, alterar ou circular o programa.

Alguns doutrinadores, entre eles Gabriel Francisco Leonardos 165, analisando a natureza jurídica do contrato de licenciamento, concluíram tratar-se de um contrato de locação (se onerosa), ou de um contrato de comodato (se gratuita). Por intermédio de um contrato de licenciamento dá-se a cessão do exercício das faculdades de uso e fruição ou exploração, típicas dos contratos de locação e comodato, conforme seja ela onerosa ou gratuita.

No mesmo sentido, Fábio Ulhoa, analisando o contrato de licença de direito industrial, equipara a figura do licenciador ao locador e do licenciado ao locatário; desta forma, aplica-se subsidiariamente às normas específicas da legislação de direito industrial o regime jurídico do contrato de locação de coisas móveis $(\mathrm{CC}$, arts. 1.188 a 1.199). ${ }^{166}$

O autor da obra ou programa pode licenciar o direito não exclusivo de utilizar o bem a um distribuidor ou diretamente ao consumidor final, mediante certas condições admitindo-se limitações temporais ou territoriais.

\subsubsection{Da Locação}

A Lei de Proteção ao Software, Lei $n^{\circ}$ 9.609/98, apesar de prever expressamente que o uso dos programas será objeto de contrato de licença ${ }^{167}$, autoriza no $\S 5^{\circ}$ do art. $2^{\circ}$ também sua "locação comercial". Vejamos o teor do artigo:

Inclui-se dentre os direitos assegurados por esta Lei e pela legislação de direitos autorais e conexos vigentes no País aquele direito exclusivo de autorizar ou proibir o aluguel comercial, não sendo esse direito exaurível pela venda, licença ou outra forma de transferência da cópia do programa.

O Código Civil Brasileiro disciplina a "Locação de Coisas" nos artigos 565 e seguintes. Neste contrato, o locador se obriga a ceder à outra parte, o locatário, "por

165 Perfilam-se também a esta corrente Luiz Leonardos, Paulo Borges Figueiredo e Gama Cerqueira. Cf. LEONARDOS, Gabriel Francisco, op. cit. (nota 152), pp. 86-87.

${ }^{166}$ Cf. COELHO, Fábio de Ulhoa, Curso de Direito Comercial, v. 1, $4^{\mathrm{a}}$ ed. rev., atual., São Paulo, Saraiva, 2003, p. 164.

${ }^{167}$ Lei $9.609 / 98$ - “Art. $9^{\circ} \mathrm{O}$ uso de programa de computador no País será objeto de contrato de licença”. 
tempo determinado ou não, o uso e gozo de coisa infungível, mediante certa remuneração, designada aluguel". 168

O objeto da locação de qualquer espécie não é a coisa em si mesma ou no trabalho, mas simplesmente seu uso e gozo temporário. ${ }^{169}$

Convém ressaltar que o regime de proteção à propriedade intelectual de programa de computador é o mesmo conferido às obras literárias pela legislação de direitos autorais, que são, por determinação legal, "bens móveis" (art. $3^{\circ}$ da Lei n 9.610/98).

Neste compasso, a natureza jurídica dos programas de computador ganha relevância na medida em que, por força da Súmula Vinculante $n^{\circ} 31^{170}$, é inconstitucional a incidência do Imposto Sobre Serviços de Qualquer Natureza sobre a locação de bens móveis.

\subsubsection{Da Cessão de Direitos}

A cessão de direitos é o contrato de transferência da propriedade e dos direitos a ela inerentes, distinguindo-se do contrato de licença que abarca somente a concessão do exercício destes direitos. Fábio Ulhoa adverte que "a licença de direito industrial está para a cessão, como a locação está para a venda”. A opção pelo regime de cessão ou licença é livre de pactuação entre as partes. ${ }^{171}$

A cessão de direitos relativa ao software pode referir-se (i) aos direitos de exploração do bem, assim como (ii) aos direitos sobre a reprodução do programa ou do arquivo digital. No caso de cessão dos direitos de exploração o autor, ou seu sucessor, transfere um ou mais dos direitos patrimoniais que detém sobre sua criação, podendo a cessão ser total, quando compreende todos os direitos titularizados pelo cedente, ou parcial.

Pela cessão de direitos de exploração do software o autor transfere, a título oneroso ou gratuito, um ou mais direitos patrimoniais sobre sua criação intelectual. Nos termos do disposto no art. 49 da Lei de Direitos Autorais, a cessão pode ser total ou

${ }^{168}$ DINIZ, Maria Helena, Código Civil Anotado, 9a . ed., São Paulo, Saraiva, 2003, p. 565.

${ }^{169}$ Cf. LOPES, Miguel M. de Serpa, Curso de Direito Civil, v. 3, Rio de Janeiro, Freitas Bastos, 1991, p. 21.

${ }^{170}$ A Súmula Vinculante $\mathrm{n}^{\circ} 31$ foi publicada no DJe $\mathrm{n}^{\circ} 28$ de 17.2.2010, p. 1. Disponível em: <http://www.stf.jus.br/portal/cms/verTexto.asp?servico=jurisprudenciaSumulaVinculante\&pagina=sumul a 001 032>. Acesso em 18 de abril de 2012.

${ }_{171}$ COELHO, Fábio de Ulhoa, op. cit. (nota 166), p. 165. 
parcial, e ocorre somente para a modalidade de utilização já existente à época do contrato. 172

A cessão dos direitos sobre reprodução do programa (no caso de software) permite ao cessionário a cópia do próprio programa, além de implicar ainda o contrato na concessão do direito de modificar e adaptar o software com o intuito de aprimorá-lo, de introduzir novas funcionalidades, de corrigir erros, ajustar e adaptar a plataformas diferentes. ${ }^{173}$

Os aspectos formais do contrato de cessão estão elencados no art. 50 da Lei de Direitos Autorais:

Art. 50. A cessão total ou parcial dos direitos de autor, que se fará sempre por escrito, presume-se onerosa.

$\S 1^{\circ}$ Poderá a cessão ser averbada à margem do registro a que se refere o art. 19 desta Lei, ou, não estando a obra registrada, poderá o instrumento ser registrado em Cartório de Títulos e Documentos.

$\S 2^{\circ}$ Constarão do instrumento de cessão como elementos essenciais seu objeto e as condições de exercício do direito quanto a tempo, lugar e preço.

Note-se que o contrato, além de necessariamente escrito, deve ser averbado à margem do registro da marca ou patente, ou no caso de obra não registrada no Cartório de Títulos e Documentos. Importante ressaltar que a cessão pode ser concedida diretamente pelo autor ou por meio de representantes com poderes especiais, presumindose, em caso de omissão, oneroso.

Considerando que na cessão do direito de propriedade intelectual sobre programa de computador ocorre a transferência de todos os direitos sobre o mesmo, havendo desta forma a transferência jurídica do bem, Guilherme Cezaroti qualifica a operação como venda de mercadoria intangível, concluindo que incide nestas operações o ICMS - Imposto sobre a Circulação de Mercadorias. ${ }^{174}$

${ }^{172}$ Lei n 9.610/1998 - Art. 49, inciso V - “a cessão só se operará para modalidades de utilização já existentes à data do contrato." As modalidades de utilização, previstas no inciso VII do art. 29 da mesma norma.

${ }^{173}$ Cf. EMERENCIANO, Adelmo da Silva, op. cit. (nota 39), pp. 95-96.

${ }^{174}$ Cf. CEZAROTI, Guilherme, op. cit. (nota 164), p. 118. 
Esta não é, contudo, a posição do Supremo Tribunal Federal, que afastou a pretensão do Estado de São Paulo em tributar pelo ICMS as operações de licenciamento ou cessão de direito de uso de programas de computador. ${ }^{175}$

\begin{abstract}
[...]
III. Programa de computador ("software"): tratamento tributário: distinção necessária. Não tendo por objeto uma mercadoria, mas um bem incorpóreo, sobre as operações de "licenciamento ou cessão do direito de uso de programas de computador", "matéria exclusiva da lide", efetivamente não podem os Estados instituir ICMS: dessa impossibilidade, entretanto, não resulta que, de logo, se esteja também a subtrair do campo constitucional de incidência do ICMS a circulação de cópias ou exemplares dos programas de computador produzidos em série e comercializados no varejo - como a do chamado "software de prateleira" (off the shelf) - os quais, materializando o corpus mechanicum da criação intelectual do programa, constituem mercadorias postas no comércio.
\end{abstract}

Segundo o relator, a cessão de direito de uso de programas de computador é operação cujo objeto é um direito de uso, bem incorpóreo insuscetível de ser incluído no conceito de mercadoria. Não era objeto do mencionado julgamento a incidência do ISS - Imposto sobre Serviços.

O contrato de cessão de direitos não pode ser confundido com o contrato de compra e venda; neste há a transferência da titularidade de uma mercadoria em caráter definitivo. Já na cessão de direitos há uma transferência de direitos, em regra, a título precário. Além disto, na cessão de direitos, os direitos morais do autor, embora limitados, não são transferidos, constituindo direitos indisponíveis e inalienáveis. ${ }^{176}$

Marcelo Caron assevera que as cessões de direito de bens imateriais, independente de seu objeto específico, não implicam obrigações de fazer. Tratar-se-ia de mera relação contratual, cuja prestação não corresponde a um esforço humano. ${ }^{177}$

De modo geral, identificados os negócios jurídicos pelos quais os bens digitais são transacionados no comércio eletrônico, estudaremos no capítulo 6 os aspectos relativos à tributação destes contratos.

175 Recurso Extraordinário n ${ }^{\circ}$ 176.626-3/SP, STF, 1 ${ }^{\text {a }}$. Turma, rel. Min. Sepúlveda Pertence, j. 10.11.1998, DJU 11.12.1998, p. 10. Disponível em: 〈www.stf.jus.br〉. Acesso em 23 de outubro de 2012.

${ }^{176}$ Lei $\mathrm{n}^{\circ} 9.610 / 98$ - O art. 49 prevê as limitações aplicáveis no caso da transferência do direito do autor, entre as quais a exclusão dos direitos de natureza moral. Inciso I: "a transmissão total compreende todos os direitos de autor, salvo os de natureza moral e os expressamente excluídos por lei” (g.n.).

${ }^{177}$ Cf. BAPTISTA, Marcelo Caron, ISS do texto à norma - Doutrina e Jurisprudência da EC 18/65 à LC 116/03, São Paulo, Quartier Latin, 2005, p. 352. 


\subsubsection{Cloud Computing: a virtualização do cenário tecnológico}

Atuar ou se estabelecer na área de Internet, operando por meio do comércio eletrônico, demanda serviços de infraestrutura, tais como software e hardware, hospedagem de servidores, conexões de rede e links, aplicativos, serviços de backup, de consultoria, de manutenção, dentre outros, que têm sido supridos por uma categoria de empresas especializadas. ${ }^{178}$

Ademais, hodiernamente vivemos em uma sociedade cada vez mais dependente da tecnologia; neste cenário, os mais variados segmentos dependem da tecnologia da informação como as redes elétricas, o controle de tráfego, o setor de saúde, o abastecimento de água, a alimentação, além da maior parte das transações financeiras mundiais. Por outro giro, a informática ${ }^{179}$ tornou-se indispensável em diversas atividades de todos os ramos de negócios, inclusive no setor público, aumentando a demanda por soluções de tecnologia. Com a sofisticação dos equipamentos e a evolução da tecnologia da informação, empresas de todas as áreas possuem, em maior ou menor escala, necessidade de equipamentos, softwares e pessoal voltados especificamente para a área.

Com a especialização de algumas empresas, a terceirização tem se tornado cada vez mais vantajosa para as instituições, deixando de manter toda a infraestrutura de TIC em suas dependências, encaminhando-a para a Internet, para empresas que detêm servidores compartilhados, programas, serviços de armazenagem e processamento de dados.

Ou seja, a solução adotada por algumas empresas, em especial as micro e pequenas empresas, tem sido a transferência das atividades não essenciais a terceiros, buscando uma racionalização de custos, economia de recursos e desburocratização administrativa.

Os recursos disponibilizados por empresas especializadas, além de significar um custo menor, são normalmente mais rápidos, eficientes no processamento e possuem uma disponibilidade de grandes espaços em memória de armazenamento.

\footnotetext{
${ }^{178}$ Cf. MARTINS, Ricardo Lacaz e RABELLO, Carolina M. Motta, Algumas Considerações a Respeito dos Contratos de Nivel de Serviços - SLAs, In Internet - O Direito na Era Virtual, SCHOUERI, Luis Eduardo, organizador, $2^{\mathrm{a}}$. ed, Rio de Janeiro, Forense, 2001, p. 379.

${ }^{179} \mathrm{O}$ termo "informática" foi aqui utilizado para abranger toda a estrutura física de hardware e os softwares.
} 
Nesta esteira, surgiram dois novos tipos de empresas prestadoras de serviço que atuam especificamente na área das tecnologias digitais, denominadas Internet Data Centers (IDCs) ou Application Service Providers (ASPs).

Os IDCs, concebidos originalmente como espaços voltados à hospedagem física de equipamentos, são hoje locais que possuem instalações de servidores agregadas a uma série de outros serviços, como: "a locação de equipamentos, a disponibilização de infraestrutura física e lógica, hospedagem de sites, conectividade em Protocolo de Internet, garantia de fluxo contínuo e ininterrupto de energia elétrica, gerenciamento e segurança de equipamentos e dados". 180

Já os ASPs são prestadores de serviços que, operando em conjunto com os IDCs, proveem os aplicativos (softwares) necessários às empresas que se utilizam dos Data Centers. Os ASPs atuam, via de regra, em Data Centers de terceiros, administrando seus aplicativos e disponibilizando os serviços contratados. Ao invés de cada uma das empresas possuir equipamentos e pessoal voltados à área de TI, os IDCs e ASPs disponibilizam servidores localizados fora delas, ou seja, servidores "remotos", onde são processados e armazenados os dados e programas de diversas empresas.

Este cenário favoreceu o surgimento de um novo "fenômeno" na área da tecnologia da informação: o cloud computing, ou "virtualização", que está deslocando dos microcomputadores dos usuários, ou dos servidores de dados das empresas, para "as nuvens" os arquivos, programas, o processamento e outros dados relacionados. O cloud computing é "um grande conjunto de recursos que abarca servidores, impressão, armazenamento e também processos". ${ }^{181}$

A denominação de "nuvem", ao invés do que se possa imaginar, não está associada a estarem os dados dispersos no ar, analogamente ao que ocorre na tecnologia wireless; é que na área de informática e telecomunicações, o desenho de uma nuvem é utilizado para fins de abstração. A "nuvem" representa em diagramas de rede tanto a Internet como alguma rede cujas características não necessitem ser detalhadas. Por exemplo, "se a ideia é a de explicar como funciona uma tecnologia de comunicação que

\footnotetext{
${ }^{180}$ MARTINS, Ricardo Lacaz e RABELLO, Carolina M. Motta, op. cit. (nota 178), p. 380.

${ }^{181}$ Cf. BARROS, Fábio, Cloud Computing: prepare-se para a nova onda em tecnologia. Disponível em: $<$ http://computerworld.uol.com.br/gestao/2008/04/17/cloud-computing-prepare-se-para-a-nova-onda-emtecnologia/>. Acesso em 10 de outubro de 2012.
} 
interliga duas redes de computadores, não é necessário detalhar as características de cada uma. Assim, pode-se utilizar uma nuvem para indicar que há redes ali”. 182

Cloud computing está associado à ideia de provisionamento de recursos de TI e de serviços escaláveis, em qualquer lugar e independente de plataforma, das mais variadas aplicações, como se estivessem instaladas no computador do usuário. ${ }^{183}$

Neste modelo, o conteúdo fica disponível nas "nuvens", ou seja, na Internet, cabendo ao fornecedor da aplicação as tarefas de desenvolvimento, armazenamento, manutenção, atualização, backup e escalonamento, enquanto o usuário necessita somente de um dispositivo de acesso (personal computer, tablet, smartphone, etc.) que lhe possibilite acessar e utilizar.

Impende ressaltar que a arquitetura em cloud exige uma complexa infraestrutura de gerenciamento, que inclui, entre outras, as funções de provisionamento dos recursos computacionais, monitoração do desempenho e controle do fluxo de trabalhos que serão processados em um ambiente computacional na nuvem de processamento, e o retorno do trabalho pronto direcionado ao dispositivo de saída do solicitante (workload). 184

Vale dizer, alguém assume a responsabilidade de prover algumas funções de TI como serviços para alguns clientes, que não precisam conhecer o modelo ou possuir equipe e equipamentos próprios. ${ }^{185}$

O National Institute of Standards and Technology - NIST tem adotado uma definição de cloud computing amplamente usada no setor de TI. Segundo aquele órgão, cloud computing é um modelo de arquitetura que permite um acesso conveniente, onipresente e sob demanda a uma rede que representa um pool compartilhado de recursos computacionais configuráveis, que podem ser rapidamente provisionados e liberados por intermédio de uma mínima interação ou gerenciamento com o provedor de serviços. ${ }^{186}$

182 Cf. ALECRIM, Emerson, O que é Cloud Computing? Disponível em: $<$ http://www.infowester.com/cloudcomputing.php>. Acesso em 12 de outubro de 2012.

${ }^{183}$ Cf. VERAS, Manoel, op. cit. (nota 79), p. XI.

${ }^{184}$ Cf. BARROS, Fábio, op. cit. (nota 181). Acesso em 12 de outubro de 2012.

185 Cf. MOREIRA, Daniela, Cloud Computing: entenda esse novo modelo de computação, Disponível em: <http://idgnow.uol.com.br/ti-corporativa/2008/08/13/cloud-computing-entenda-este-novo-modelo-decomputacao/>. Acesso em 12 de outubro de 2012.

186 Cf. MELL, Peter. GRANCE, Timothy, The NIST - National Institute of Standards Technology Definition of Cloud Computing. U.S. Departament of Commerce. Disponível em: <http://csrc.nist.gov/publications/nistpubs/800-145/SP800-145.pdf>. Acesso em 13 de outubro de 2012. 
São cinco as características essenciais do cloud computing segundo o órgão norte-americano: (i) on-demand self-service: o consumidor pode unilateralmente alterar as configurações dos serviços, conforme suas necessidades, como o tempo de utilização do servidor de dados, capacidade de processamento de dados, sem qualquer interação com cada prestador de serviço; (ii) acesso amplo à rede: os recursos podem ser acessados por meio de diversos mecanismos como tablets, notebooks, telefones celulares e estações de trabalho; (iii) pool de recursos: os recursos de computação do provedor são agrupados para atender múltiplos consumidores por meio da atribuição dinâmica de diferentes recursos físicos e virtuais, evitando a dependência de um único recurso físico e proporcionando ainda escalabilidade para crescer e processamento garantido e isolado para cada cliente; (iv) elasticidade rápida: as capacidades disponíveis de armazenamento, processamento e outras podem ser ampliadas e reduzidas automaticamente de acordo com as necessidades do cliente de forma automática; e (v) serviço medido: o consumidor tem acesso a uma espécie de monitor que controla e otimiza o uso dos recursos, que são medidos com algum tipo de abstração, apropriado para cada tipo de serviço, vale dizer, o uso dos recursos pode ser monitorado e controlado, de forma transparente tanto para o provedor como para o consumidor do serviço utilizado. ${ }^{187}$

Ainda segundo o NIST, a utilização dos recursos em pool no cloud computing implica um senso de independência de localização em que o cliente geralmente não tem controle ou conhecimento sobre a localização exata dos recursos disponibilizados, mas pode ser capaz de especificar o local em um nível maior de abstração (por exemplo, país, estado ou datacenter).

Cloud computing representa, segundo Haluk Demirkan, professor de sistemas de informação na WP Carey School of Business, uma "aplicação em escala muito maior. Agora, estamos falando de milhares de computadores ligados entre si, através da Internet ou outra rede". 188

Trata-se de um "novo conceito" em que o usuário, ou as empresas, preocupam-se somente com um equipamento que acesse a Internet; todos os dados, documentos, manutenção, armazenamento, atualização de software, backup, escalonamento passam a ser tarefas do fornecedor da aplicação.

${ }^{187}$ Cf. MELL, Peter. GRANCE, Timothy, op. cit. (nota 186). Acesso em 13 de outubro de 2012.

188 LOEFF, Betsy, Cloud Computing: The Evolution of Software-as-a-Service, W.P. Carey School of Business at Arizona State University. Revista Eletrônica KnowWPC. Disponível em: <http://knowledge.wpcarey.asu.edu/article.cfm?articleid=1614 >. Acesso em 13 de outubro de 2012. 
E o acesso amplo possibilitado por este novo modelo computacional, por qualquer tipo de dispositivo, permite que não seja mais necessária a utilização de equipamentos potentes pelos usuários para acessar as aplicações. Isto porque, como a parte mais pesada do processamento fica na "nuvem", o usuário final só precisa de um browser e uma boa conexão à Internet. ${ }^{189}$

Ou seja, o usuário contrata a utilidade, muitas vezes a partir de computadores com pouca capacidade de memória (computadores "magros"), justamente porque operará softwares e arquivos de forma remota (não há download) e sem uma localização física específica e pré-definida.

O Google Docs é um exemplo prático deste novo conceito; com ele, os usuários podem editar textos, fazer planilhas, elaborar apresentações de slides, armazenar arquivos, sem a necessidade de ter instalados em sua máquina programas que elaborem estas atividades, como o Microsoft Office, adquiridos por meio de licenças de uso. ${ }^{190}$

O fundamento do modelo é o princípio do "One-to-Many Service", ou seja, uma única empresa, que engloba múltiplas funções (hardware e software), e presta serviços de alta performance para várias empresas contratantes, o que reduz significativamente gastos, já que há ganho na economia de escala. Em decorrência deste modelo, os serviços oferecidos costumam ser padronizados, admitindo customizações somente em casos de clientes com grandes demandas. ${ }^{191}$

As relações jurídicas existentes entre estas empresas e os tomadores destes serviços são regidas por contratos denominados Acordo de Nível de Serviço, ou Service Level Agreements (SLA). Estes contratos disciplinam as responsabilidades destas empresas com os tomadores dos serviços, definindo, entre outros itens, a qualidade, o nível do serviço e as medidas em caso de descumprimento das obrigações. Como a propriedade dos softwares permanece com os ASPs, que se obrigam a fornecer updates, se for o caso, e a dar a manutenção necessária, não há a obrigação legal dos contratantes em licenciar tais aplicativos. $^{192}$

Uma empresa que deseja atuar no mercado de e-business encontra na contratação dos IDCs e ASPs velocidade na implementação das aplicações (já que toda a

\footnotetext{
${ }^{189}$ Cf. MOREIRA, Daniela, op. cit. (nota 185). Acesso em 12 de outubro de 2012.

${ }^{190}$ Cf. ALECRIM, Emerson, op. cit. (nota 182). Acesso em 12 de outubro de 2012.

${ }^{191}$ Cf. MARTINS, Ricardo Lacaz e RABELLO, Carolina M. Motta, op. cit. (nota 178), p. 380.

${ }^{192}$ Cf. Idem, ibidem, p. 380.
} 
estrutura está pronta), economia de custo e a possibilidade de concentrar sua atuação nas atividades-chave da empresa, terceirizando o suporte tecnológico.

Importante ressaltar que, apesar de prestar serviços voltados totalmente às tecnologias digitais, os Internet Data Center não prescindem de uma base física em que estarão localizados os servidores de dados e em que os ASPs prestarão os serviços para seus clientes.

No entanto, neste modelo de nuvem "estamos falando de uma escala que não é mais local, mas sim global. O Google tem dezenas de data centers espalhados pelo mundo. Todos prestam serviços não a um país, mas a diversos, atendendo milhões de usuários". 193

\subsubsection{Cloud Computing: novas categorias de "serviços"?}

Atrelado ao fenômeno do cloud computing surgiu o conceito do Software como Serviço, no original Software as a Service (SaaS). Trata-se de uma nova "modalidade" de disponibilização de software, que é oferecido como um serviço, dispensando a aquisição de licença de uso ou servidores para executá-lo, que seria a grande vantagem do modelo. A remuneração pelos "serviços" é periódica e abrange somente os recursos efetivamente utilizados e/ou pelo tempo de uso, numa exploração do modelo payper-use. ${ }^{194}$

A vantagem do modelo é que o preço de aquisição da licença é diluído ao longo do tempo, além de prescindir de atualizações, que ficam a cargo dos provedores. Some-se a isto o fato de que o modelo dispensa a aquisição da infraestrutura de hardware necessária para a utilização das aplicações vendidas como serviços. ${ }^{195}$

Estes seriam fatores determinantes para alcançar o mercado das pequenas e médias empresas ou, no idioma da TI, SMBs (small and medium business), que representam hoje $21 \%$ do PIB - produto interno bruto e que, segundo o Sebrae, empregam

${ }^{193}$ Cf. MOREIRA, Daniela, op. cit. (nota 185). Acesso em 12 de outubro de 2012.

${ }^{194}$ Cf. ALECRIM, Emerson, op. cit. (nota 182). Acesso em 12 de outubro de 2012.

${ }^{195}$ CHEROBINO, Vinicius, SaaS: Quatro letras para conquistar as pequenas empresas, Revista Eletrônica Computerworld. Disponível em: <http://computerworld.uol.com.br/gestao/2007/10/16/idgnoticia.2007-

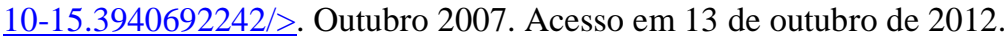


$60 \%$ da população economicamente ativa do país e estão espalhadas por todos os estados do Brasil. ${ }^{196}$

\subsubsection{Tecnologia As a Service?}

A tecnologia do cloud computing introduziu ainda no mercado da informática, até o momento, além da SaaS, outras duas categorias principais de tecnologia. Baseadas no conceito de utilização sem a necessidade da aquisição de licenças, que são remuneradas em função da utilização, são tidas como "serviços". Derivadas da língua inglesa, as denominações trazem a expressão que as caracteriza: as a service, isto é, "como um serviço".

As três principais classes destes "serviços" são a Infrastructure as a Service (IaaS), a Platform as a Service (PaaS) e o Software as a Service (SaaS). No mercado nacional, estas tecnologias estão sendo denominadas, respectivamente, Infraestrutura como Serviço, Plataforma como Serviço e Software como Serviço.

O conceito de SaaS está relacionado "à troca de um modelo de software baseado em venda de licenças (CAPEX) por um modelo baseado no uso do software como serviço (OPEX)". ${ }^{197}$ A sigla OPEX deriva da expressão Operational Expenditure e está relacionada ao "custo dispendido continuamente para manter a produção de um produto ou serviço ou para manter em funcionamento um negócio ou um determinado sistema". CAPEX é a sigla para Capital Expenditure e designa "o custo de desenvolvimento ou fornecimento dos próprios bens de capital ou de partes não-consumíveis do sistema, necessários à produção e à manutenção em funcionamento do negócio ou sistema”. 198

Para entendermos o modelo do "Software como Serviço" - SaaS, vamos supor que uma empresa necessite de um software para gerar sua folha de pagamento; ela poderá escolher, entre várias soluções prontas, um produto adequado que deverá ser adquirido por licença de uso. Além disto, deverá ter pessoal próprio para utilizar o software, que deverá ser treinado, e hardware compatível com as necessidades da solução adquirida. Já no modelo SaaS, o serviço poderá ser oferecido por meio de cloud

${ }^{196}$ CHEROBINO, Vinicius, op. cit. (nota 195). Acesso em 13 de outubro de 2012.

${ }^{197}$ VERAS, Manoel, op. cit. (nota 79), p. 173.

198 NUNES, Paulo, Conceito de OPEX, 2009, Disponível em: <http://www.knoow.net/cienceconempr/gestao/opex.htm $>$. Acesso em 12 de outubro de 2012. 
computing, acarretando as seguintes vantagens para o adquirente: o custo será proporcional ao número de usuários e/ou tempo de uso; economia na aquisição de hardware, na instalação, atualização, manutenção, na equipe de TI, entre outros, custos que são absorvidos pelo fornecedor da solução; além disto, a utilização do aplicativo é praticamente imediata. $\mathrm{O}$ adquirente deve preocupar-se somente com o acesso à Internet $\mathrm{e}$ dispositivos para acessar a solução. ${ }^{199}$

Por outro giro, "o consumidor não gerencia ou controla a infraestrutura de nuvem subjacente, incluindo rede, servidores, sistemas operacionais, armazenamento, ou mesmo capacidades de aplicativos individuais, com a possível exceção das limitadas configurações específicas do usuário de configuração do aplicativo". 200

A grande vantagem do modelo está em dispensar a aquisição de licenças de uso de software, sendo os serviços remunerados de acordo com um modelo de assinatura: os clientes pagam pelo uso do aplicativo uma taxa contínua, baseada na utilização dos recursos. ${ }^{201}$

As grandes empresas de TI já oferecem soluções em SaaS, como a IBM e a HP. A IBM, por exemplo, oferece pelo sistema cloud computing uma grande variedade de soluções de software como serviço (SaaS) para empresas, como webconferências, correio eletrônico, redes sociais, reuniões on-line e outras ferramentas voltadas às empresas. $^{202}$

Outra tecnologia oferecida por meio do cloud computing é a Infraestrutura como Serviço - IaaS, que "é a capacidade que o provedor tem de oferecer uma infraestrutura de processamento e armazenamento de forma transparente para o cliente, normalmente uma organização". ${ }^{203}$

Os conceitos de SaaS e IaaS são bem conhecidos no mercado de informática e utilizados por diversas empresas. Já o PaaS, ou Plataforma como Serviço, é a utilização de uma plataforma de desenvolvimento de softwares de terceiros, incluindo aplicativos, interfaces e bancos de dados, mediante o pagamento de um valor correspondente a uma assinatura. Está relacionado ao uso de um repositório de ferramentas de desenvolvimento de programas, que são oferecidas pelos provedores de serviços, a

\footnotetext{
${ }^{199}$ Cf. ALECRIM, Emerson, op. cit. (nota 182). Acesso em 12 de outubro de 2012.

${ }^{200}$ Cf. MELL, Peter. GRANCE, Timothy, op. cit. (nota 186). Acesso em 13 de outubro de 2012.

${ }^{201}$ Cf. VERAS, Manoel, op. cit. (nota 79), p. 196.

${ }^{202}$ Cf. <http://www.ibm.com/br/services/cloud_services/index.phtml >.

${ }^{203}$ VERAS, Manoel, op. cit. (nota 79), p. 147.
} 
partir dos quais os desenvolvedores criam aplicativos utilizando a Internet como meio de acesso. Os servidores de dados representam altos custos de operação em função de seu complexo gerenciamento e do mau aproveitamento de seus recursos. Surgiram então como solução, as máquinas ou servidores virtuais, sendo possível alocar vários servidores virtuais em um mesmo servidor físico, otimizando, desta forma, os recursos. ${ }^{204}$

Além das classes já mencionadas, muitas outras têm surgido no mercado, sendo atualmente reconhecidas as seguintes categorias de "serviço": armazenamento como serviço, banco de dados como serviço, informação como serviço, processo como serviço, integração como serviço, segurança como serviço, gestão como serviço e teste como serviço.

O Armazenamento como Serviço, como indica o nome, é a disponibilização de um storage fisicamente em um site remoto, mas que logicamente é utilizado como um recurso local. Por meio do Banco de Dados como Serviços, pode-se utilizar, de modo compartilhado com outros usuários, um banco de dados hospedado remotamente. Nesta modalidade, ao invés de despender milhares de dólares em hardware e em licenças de software, o usuário paga apenas pelos recursos utilizados.

No Processo como Serviço, são disponibilizados ao usuário recursos como serviços e dados, hospedados remotamente, para criar processos de negócio. Fornecidos sob demanda, este serviço pode ser alterado de forma ágil, ao contrário de aplicativos que devem ser substituídos.

A Integração como Serviço é a "capacidade de fornecer uma pilha de integração completa a partir da cloud, incluindo interfaceamento com aplicativos, mediação semântica, controle de fluxos, design de integração e assim por diante. Em essência, a integração como serviço abrange a maioria dos recursos e das funções encontrados na tecnologia convencional de enterprise application integration (EAI), mas fornecidos como um serviço". ${ }^{205}$

E até mesmo os serviços de segurança essenciais relacionados à informática podem ser fornecidos remotamente via Internet por meio da tecnologia de Segurança como Serviço. Outro aplicativo do sistema tem a capacidade de testar sistemas

\footnotetext{
${ }^{204}$ Cf. VERAS, Manoel, op. cit. (nota 79), p. 173.

${ }^{205}$ INFOWORLD/EUA, 11 Categorias de Cloud Computing. Revista Eletrônica Computerworld. Março 2010. Disponível em: <http://computerworld.uol.com.br/tecnologia/2010/03/03/11-categorias-de-cloudcomputing/>. Acesso em 12 de outubro de 2012.
} 
locais da empresa, websites, sistemas empresariais ou aqueles fornecidos em nuvem, utilizando o software e o serviço do teste hospedados remotamente.

Todos os serviços de computação prestados por meio da nuvem podem ser gerenciados usando-se outro serviço: a Gestão como Serviço. Por meio dela, é possível realizar a medição de um ou mais serviços prestados em cloud computing, como o gerenciamento do tempo de atividade, a topologia, a utilização de recurso, entre outros, aferindo as quantidades utilizadas. ${ }^{206}$

O conceito de cloud computing está conquistando não apenas o setor privado; a Universidade de São Paulo - USP é a primeira do setor da educação no Brasil a utilizar um sistema de computação em nuvem, que já é comum nas rotinas de universidades do exterior, como Harvard, Stanford e Massachusetts Institute of Technology (MIT), e em empresas como Google, Amazon e Microsoft, entre outras. A Universidade está investindo 200 milhões de dólares no projeto Cloud USP, que possibilitará aos usuários (alunos, professores e funcionários) o acesso a informações por qualquer dispositivo móvel. ${ }^{207}$

O projeto atingirá todos os centros de informática da USP, que serão reunidos em Internet Data Centers (IDCs), que abrigarão um conjunto de supercomputadores formando a "nuvem". Os benefícios esperados são a visibilidade da própria instituição e a economia de recursos.

O governo brasileiro também está traçando um plano estratégico visando à adoção do cloud computing, por meio do programa IT Maior, gerido pelo Ministério da Ciência e Tecnologia. Com o programa, espera-se aumentar a competitividade do software nacional frente aos importados, além de reduzir os índices de pirataria, tendo como foco principalmente as micro e pequenas empresas pelo modelo SaaS. ${ }^{208}$ O Ministério da Ciência e Tecnologia deverá destinar 50 milhões de reais nos próximos dois anos para programas de apoio a empresas que irão explorar esse mercado.

A economia de recursos tem sido um dos grandes diferenciais e atrativos do modelo; os custos do setor do governo norte-americano, desde que foi adotado a cloud

${ }^{206}$ Cf. INFOWORLD/EUA, op. cit. (nota 205). Acesso em 12 de outubro de 2012.

207 USP investe US\$ 200 milhões em projeto de cloud computing, Disponível em: <http://computerworld.uol.com.br/tecnologia/2012/09/24/usp-investe-us-200-milhoes-em-projeto-decloud-computing >. Acesso em 25 de outubro de 2012.

${ }^{208}$ Cf. SOARES, Edileuza, O Brasil se prepara para dar um salto em Cloud Computing, Revista Eletrônica CIO, Agosto 2012, Disponível em: <http://cio.uol.com.br/noticias/2012/08/09/brasil-se-prepara-para-darum-salto-em-cloud-computing/>. Acesso em 31 de outubro de 2012. 
computing, caíram de 2,5 milhões de dólares para 800 mil dólares. Neste diapasão, o Reino Unido economizou 3,2 bilhões de libras de um orçamento de 16 bilhões de libras. ${ }^{209}$

Um dos desafios apontados pelos gestores públicos em relação ao modelo de computação nas nuvens é as definições de como serão as compras governamentais de tecnologia por meio desta modalidade, já que, ao invés de comprar equipamentos e softwares, o governo irá comprar a utilização de "serviços". ${ }^{210}$

Quando o modelo de disponibilização de recursos de informática foi importado, carregou consigo a expressão que compõe a denominação de todos os seus componentes: As a Service, ou seja, "Como um Serviço".

E aqui se elucida nossa abordagem sobre cloud computing, que possui um grande potencial de crescimento, justificando a importância de desvendar sua real natureza jurídica. Caso esta modalidade de disponibilização de recursos de TI constitua-se, verdadeiramente, em uma prestação de serviços, incidirá sobre tais atividades o ISS, de competência municipal, trazendo ínsita a questão de "quem deve tributar".

209 Cf. VERDI, Fábio Luciano, Cloud Computing, Data Centers e Governo: desafios e oportunidades. Disponível em: 〈http://www.ppgccs.net/verdi/csbc wcge10.pdf>. Acesso em 26 de outubro de 2012.

${ }^{210}$ Cf. SOARES, Edileuza, op. cit. (nota 208). Acesso em 31 de outubro de 2012. 


\section{A TRIBUTAÇÃO DO COMÉRCIO ELETRÔNICO INTERNACIONAL}

Nos últimos tempos, os Estados têm se deparado com as transformações oriundas do processo de globalização, que, ao impor-lhes novas realidades econômicas, desafia suas capacidades de enfrentar problemas como a mobilidade do capital, a atuação virtual das empresas no mercado e a competição tributária estabelecida em nível internacional. Neste contexto, alguns estudiosos, os Estados e as organizações internacionais de regulação econômica, assim como as de cunho político, vêm repensando vários aspectos do modelo de tributação existente. ${ }^{211}$

$\mathrm{Na}$ medida em que o comércio eletrônico facilita a realização de transações entre partes que se encontram, muitas vezes, situadas em países diferentes, os negócios eletrônicos revelam um caráter internacional.

211 A Organização para a Cooperação e Desenvolvimento Econômico - OCDE, a Organização das Nações Unidas - ONU, e em especial o Group of Experts, Grupo Ad hoc de Peritos em Cooperação Internacional em Questões Tributárias, que atua no âmbito da ONU, são exemplos de organizações/grupos que têm se voltado a estudar os problemas na tributação. 
As normas tributárias vigentes neste cenário, concebidas há mais de um século, não contemplam esta nova realidade, exigindo um grande trabalho de interpretação para que possam ser aplicadas à realidade do comércio eletrônico.

A questão da fixação de "quem deve tributar" no Direito Tributário Internacional se intensifica com o "comércio eletrônico", ressaltando Schoueri que a expressão abarca "todos os casos em que os meios eletrônicos nada mais são que instrumentos de comunicação para a concretização de transações tradicionais (quando se reproduzem, embora com novas fórmulas, modelos jurídicos do comércio já existente) quanto daqueles em que, por meio da Internet, ocorre a própria cessão de bens (como os serviços ou os direitos autorais)". ${ }^{212}$ Refere-se o professor aos dois tipos de comércio eletrônico a que aludimos: o comércio eletrônico direto, em que todas as etapas, os procedimentos da transação, desenvolvem-se em ambiente eletrônico, abrangendo inclusive a entrega eletrônica do bem ou serviço, e o comércio eletrônico indireto, que utiliza os meios eletrônicos em parte da transação.

O professor Avy-Yonah narrou, em situações extremas, uma operação de compra de mercadoria possibilitada pelo "comércio eletrônico", que foi reproduzida por Schoueri, sintetizando de maneira irretocável a realidade deste tipo de transação:

Num ensolarado dia, Linda Jones, acorda em sua residência em Boston e decide que, finalmente, chegou o dia de adquirir a cozinha de seus sonhos. Chega de vaguear por lojas de móveis e folhear catálogos de correio. Não. Ela fará isso diferentemente, com as vantagens do novo milênio: Linda comprará sua cozinha pela Internet. Poucos clicks em seu mouse e Linda encontra o que ela procura: kitchen.com, um site de desenho e venda de cozinhas, pertencente a KitchenCo, uma multinacional cuja controladora tem como local de constituição e administração a Guiana. Linda inicia rapidamente uma conversa eletrônica com o representante de vendas na Guiana. Ela responde suas perguntas e envia eletronicamente uma cópia das medidas de sua cozinha. Ele, por seu lado, remete seus desejos a um desenhista que trabalha em seu condomínio com vista para o mar, nas Bermudas. O desenhista consegue preencher as especificações de Linda, valendo-se de um servidor em Buenos Aires. Um empregado da empresa, residente em Sidney, Austrália, onde a empresa não exerce qualquer atividade, elabora o software de design especificamente com tal propósito.

O computador de Buenos Aires consegue exercer alguma atividade de desenho: pode checar as medidas apresentadas por Linda e compará-las com o material disponível, elaborando uma lista de possibilidades dentro do orçamento de Linda e testar cada possibilidade, tendo em vista segurança e durabilidade. $\mathrm{O}$ desenhista nas Bermudas pode valer-se de 
opções que ele buscou naquele computador, bem como um banco de dados da mesma fonte, de modo a chegar à cozinha dos sonhos de Linda. Após obter a aprovação eletrônica de Linda, o pedido é encaminhado para artesãos trabalhando na Itália, que servem como consultores, já que a construção da cozinha se dá na fábrica da empresa, na Malásia, com equipamentos fornecidos pela Alemanha. Finalmente, depois de Linda pagar, valendo-se de sua conta bancária eletrônica, a cozinha acabada é embarcada para ela da Malásia, para ser instalada em Boston. Para a instalação, Linda também recebe uma cópia do software de design, para adaptações de última hora. ${ }^{213}$

Note-se que estão envolvidos, numa mera operação de aquisição de armários, sete diferentes Estados, que potencialmente teriam o direito de tributar a operação, ou parte dela, isto sem adentrar a discussão se a referida operação no Brasil se constituiria numa venda de "mercadoria" (sujeita ao ICMS), numa "prestação de serviço sob encomenda" (tributável pelo ISS) ou ainda numa industrialização (sobre a qual incidiria o IPI).

Neste cenário, em que uma única operação de "comércio eletrônico" se desdobra em várias etapas que se pulverizam por diferentes locais do planeta, "os princípios tradicionais de tributação internacional, o Princípio da Única Tributação e o Princípio do Benefício, são ameaçados". 214

De modo similar, as regras relativas à tributação da renda proveniente da prestação de serviços, que hoje é tributada no país onde o serviço é prestado, baseando-se, portanto, na existência de um contato físico entre as partes contratantes, também devem ser repensadas. Hoje, um médico pode diagnosticar pacientes em qualquer lugar do planeta, assim como um arquiteto pode administrar uma obra sem nunca ter pisado no canteiro de obras, evidenciando que o nexo territorial tornou-se irrelevante para a atribuição da receita aos Estados. ${ }^{215}$

O "comércio eletrônico" impactou diretamente os conceitos utilizados na tributação internacional, como, por exemplo, o conceito de "estabelecimento permanente", já que o "mercado", que passa a ser eletrônico ou virtual, não possui fronteira nem

${ }^{213}$ AVY-YONAH, Reuven, International Taxation of Eletronic Commerce. Ad Hoc Group of Experts on International Cooperation in Tax Matters, Eleventh Meeting, United Nations (document ST/SG/AC.8/2003/CRP.9) Apud SCHOUERI, Luis Eduardo, op. cit. (nota 07), pp. 51/52.

${ }^{214}$ Idem, ibidem, p. 52.

${ }^{215}$ Cf. LEE, Chang Hee, Impact of E-Commerce on Allocation of Tax Revenue Between Developed and Developing Countries, Journal of Korean Law, Vol. 4, No. 1, 2004, p. 37. Disponível em: <http://papers.ssrn.com/sol3/papers.cfm?abstract_id=658103>. Acesso em 6 de junho de 2012. 
delimitação geográfica, é intangível, mas, no entanto, não é inexistente, posto que ali se realizam negócios jurídicos e se produzem rendimentos. ${ }^{216}$

$\mathrm{Na}$ verdade, a dificuldade em estabelecer a presença física ou localizar uma transação via Internet tem sido questionada por alguns doutrinadores como Glória Teixeira ${ }^{217}$, que denominou tal argumento de cyberspace fallacy, considerando que as empresas envolvidas no comércio eletrônico têm existência real, assim como seus consumidores, sendo ambos localizáveis, ainda que não estabeleçam o mesmo nível de presença física no país do consumidor, como antes se definiu.

Uma das importantes discussões provocadas pelo "comércio eletrônico" é a relativa à legitimidade dos Estados na tributação da renda de suas transações, cujos estudos defendem a tributação no Estado da residência, ainda que a OCDE continue desenvolvendo trabalhos relativos à aplicação do conceito de "estabelecimento permanente" ao comércio eletrônico. ${ }^{218}$

Aferir o local em que se produziu a riqueza e que constituiria, portanto, a fonte de produção de determinada renda, é a condição básica para a aplicação do princípio da tributação na fonte. Mas esta tem se tornado uma tarefa árdua, se não impossível, já que o próprio conceito de produção de rendimento se dilui nas transações eletrônicas, criando um desafio aos legisladores na descrição das hipóteses de incidência dos tributos, de forma que "captem a realidade em todas as dimensões, sendo provável a existência, de um lado, de lacunas legais e, de outro, de sobreposições que causem a bitributação". 219

Tornou-se crítico, também, distinguir a renda obtida nas operações realizadas pelo "comércio eletrônico", havendo nítida dificuldade em definir se tal renda é proveniente de atividades que se caracterizam como serviços, venda de mercadoria, ou se se trata de royalties. ${ }^{220}$

Neste diapasão, também a fiscalização, como forma repressiva de fuga dos capitais para os paraísos fiscais, torna-se mais inócua nestas atividades eletrônicas, já que a comprovação de simulação, feita nas atividades normais, com base na constatação de

${ }^{216}$ Cf. SCHOUERI, op. cit. (nota 115), p. 47.

217 Cf. Gary D. Sprague, Michael P. Boyle, Taxation of Income derived from Eletronic Commerce, In Cahiers de Droit Fiscal International: General Report, Vol. LXXXVIa, 2001, p. 21, Apud VASCONCELOS, Roberto de França, op. cit. (nota 113), p. 46.

${ }^{218}$ Cf. Clarification on the Application of the Permanent Establishment Definition in E-Commerce: Changes to the Commentary on The Model Tax Convention on Article 5. Disponível em <http://www.oecd.org/dataoecd/46/32/1923380.pdf >. Acesso em 2 de julho de 2011.

${ }^{219}$ SCHOUERI, Luis Eduardo, op. cit. (nota 115), pp. 50-51.

${ }^{220}$ Cf. Idem, op. cit. (nota 07), p. 53. 
uma base física (estabelecimento) ou uma equipe de vendas (estrutura organizacional), necessita de novos parâmetros.

A grande questão que se impõe relativamente à tributação do comércio eletrônico internacional é se as regras então vigentes, concebidas há cerca de oitenta $\operatorname{anos}^{221}$, coadunam-se a esta nova forma de operação, preservando o equilíbrio na distribuição das competências entre os entes. ${ }^{222}$

Acredita-se hoje que as regras vigentes de tributação da renda e do consumo, se aplicadas ao comércio eletrônico, favoreceriam os países exportadores de tecnologia, que normalmente correspondem ao local "da residência", enquanto local onde estão estabelecidas as sedes das empresas.

No atual modelo de tributação, a competência impositiva sobre a renda gerada pela venda de mercadorias é rateada entre o país "da fonte" (do consumidor), que tributa a renda derivada do marketing e da distribuição interna, e o país "da residência" (onde a mercadoria foi produzida), a quem cabe tributar a renda relativa à produção da mercadoria. No comércio eletrônico o país da residência mantém a tributação sobre a produção da mercadoria que não se altera, no entanto, o marketing e a distribuição poderão ser disponibilizados por meio de uma web page na Internet, provavelmente localizada na "residência da empresa", ou em algum paraíso fiscal. Inexistindo um "estabelecimento permanente", exclui-se a presença física que legitimava o país consumidor (fonte) a tributar parte da receita e dificulta-se a tarefa da fiscalização da operação para fins tributários. ${ }^{223}$

Neste contexto, os países importadores de tecnologia, que assumem normalmente a posição de país "da fonte" (origem dos pagamentos para o exterior), seriam prejudicados na tributação do comércio eletrônico, posto que sua legitimação para tributar hoje parte da renda gerada nas operações de comércio internacional tem como fator condicionante a "presença física" das empresas em seu território, da qual prescinde o $e$ commerce.

A utilização de meios eletrônicos e ambientes virtuais nas operações mercantis ocasiona dificuldades na aplicação das regras de tributação não apenas para os

${ }^{221}$ As regras e princípios do Direito Tributário Internacional começaram a ser discutidos na década de 1920 por um grupo de quatro economistas, por iniciativa da Liga das Nações, cuja preocupação era eliminar ou atenuar a bitributação.

${ }^{222}$ Cf. VASCONCELOS, Roberto de França, op. cit. (nota 113), p. 19.

${ }^{223}$ Cf. Idem, ibidem, pp. 26/27. 
países em desenvolvimento na determinação da "presença tributável”, mas também para os países desenvolvidos na tarefa de localização e definição da residência das pessoas jurídicas. O problema se agrava na medida em que os recursos tecnológicos que criam tais dificuldades possibilitam às empresas a administração e condução de negócios à distância a partir de um ou mais locais, podendo inclusive as empresas lançarem mão dos paraísos fiscais neste tipo de transação.

As principais questões tributárias no cenário internacional relativas ao comércio eletrônico são as seguintes: (i) a qualificação das rendas obtidas nas operações do comércio eletrônico direto; (ii) a determinação da residência dos sujeitos intervenientes e (iii) a aplicação do conceito de "estabelecimento permanente" às transações comerciais eletrônicas. ${ }^{224}$

Rever as atuais regras de tributação internacional significa alcançar um consenso dos Estados, sob pena de perder-se o atual equilíbrio da distribuição das competências impositivas, podendo resultar em pluritributação por parte daqueles países dissidentes que se julgarem legitimados a tributar (cumulativamente) tais rendas. ${ }^{225}$

\subsection{As Diretrizes Internacionais}

Os países mais desenvolvidos lideraram as primeiras discussões a respeito do comércio eletrônico, polarizadas em dois fóruns internacionais sobre o assunto - um representado pelo Departamento do Tesouro Norte-Americano (US Treasury Departament) e outro pela União Europeia, por intermédio da OCDE - Organização de Cooperação e de Desenvolvimento Econômico. Os Estados Unidos dominam o cenário do comércio eletrônico mundial, detendo, no início do século, 90\% dos servidores (servers) envolvidos nesta atividade. ${ }^{226}$

Ambos os fóruns representam países desenvolvidos, de modo que é razoável concluir que a tendência seria de tutelar os interesses destes Estados, em prejuízo dos países em desenvolvimento, que vêm adotando uma política passiva incompreensível diante do risco eminente de perda de receitas tributárias.

${ }^{224}$ Cf. CUELLO, Rafael Oliver, Fiscalidad internacional y comercio electrónico, Revista de Internet, Derecho y Política $\mathrm{n}^{\circ}$ 9, Agosto de 2009, Universitat Oberta de Catalunya, Espanha. Disponível em <http://idp.uoc.edu/ojs/index.php/...oliver/289>. Acesso em 29 de maio de 2012.

${ }^{225}$ Cf. VASCONCELOS, Roberto de França, op. cit. (nota 113), p. 15.

${ }^{226}$ Cf. Idem, ibidem, p. 30. 
Em novembro de 1996, o Departamento do Tesouro dos Estados Unidos elaborou um documento denominado Selected Tax Policy Implications of Global Eletronic Commerce, em que defendia a tributação do comércio eletrônico exclusivamente no país da residência, considerando incompatível a aplicação das regras da tributação na fonte a esta atividade mercantil. Estas regras, que têm como fator condicionante da tributação a presença física para determinar a localização geográfica, qualificação e imputação do rendimento, representariam evidentes dificuldades em sua aplicação ao novo modelo de operação mercantil do e-commerce. ${ }^{227}$

Os Estados Unidos têm se posicionado contrariamente à instituição de qualquer tributo novo sobre o comércio eletrônico que possa coibir seu desenvolvimento. Neste sentido, foi editado em 1998 o denominado Internet Tax Freedom Act of October 21, que proíbe os governos federal, estadual e local de tributar o acesso à Internet pela imposição de novas medidas tributárias discriminatórias, como o Bit Tax (taxa de bits sobre a Internet de banda larga) ou impostos sobre e-mails, o que não significa, contudo, uma isenção total de tributos para as operações realizadas pela rede. ${ }^{228}$

A medida, que inicialmente se estenderia até 21 de outubro de 2001, foi prorrogada por três vezes pelo governo norte-americano, numa demonstração clara da política adotada por esse governo diante do tema. A mais recente extensão foi introduzida pelo Internet Tax Freedom Act Amendment Act of 2007, de $1^{\circ}$ de novembro de 2007, aplicando-se a moratória até $1^{\text {o }}$ de novembro de 2014.

As primeiras diretrizes expedidas por países europeus, contidas em documentos como a Declaração de Bonn e a European Initiative in Electronic Commerce ${ }^{229}$, demonstravam a preocupação destes Estados com a discriminação das operações mercantis eletrônicas, motivo pelo qual incentivavam a adoção do Princípio da Neutralidade e do Princípio da Igualdade como diretrizes norteadoras da tributação do comércio eletrônico. A política visa a garantir que as operações mercantis do "comércio eletrônico" não sejam tributadas de maneira diversa daquela aplicada ao comércio tradicional; vale dizer, transações equivalentes devem ser igualmente tributadas.

${ }^{227}$ EUA, The Departament of Treasury, Selected Tax Policy Implications of Global Eletronic Commerce. Disponível em: <http://www.treasury.gov/resource-center/tax-policy/Documents/internet.pdf>. Acesso em 29 de maio de 2012.

${ }^{228}$ Cf. SILVA, Emenson Drigo, op. cit. (nota 102), p. 88.

${ }^{229}$ A Declaração de Bonn foi elaborada por diversos ministros da União Europeia, e a European Initiative in Eletronic Commerce, foi iniciativa da Comissão da Comunidade Europeia. 
De modo geral, os países desenvolvidos defendem a manutenção das regras e conceitos existentes relativos à tributação, repudiando também a criação de novos tributos sobre o comércio eletrônico. Em sua perspectiva, a tecnologia digital desafia as administrações tributárias e não o direito posto, ou seja, dificulta a tarefa de cobrar impostos, o que não justificaria a alteração ou o abandono das regras atuais. ${ }^{230}$ Neste diapasão, as posições da OCDE e a norte-americana convergem no sentido de que não deve ser criado qualquer tributo específico para a Internet, como o Bit $\operatorname{Tax}^{231}$, devendo-se manter as atuais regras de tributação e repudiando qualquer discriminação tributária entre o comércio convencional e o eletrônico.

O tema "comércio eletrônico e os países em desenvolvimento" foi inserido pelo Group of Experts da ONU na pauta de sua $11^{\mathrm{a}}$ reunião, em dezembro de 2003. Trabalhos da Sociedade das Nações da segunda década do século XX são considerados como a origem remota do grupo, formado com a finalidade de elaborar estudos sobre os problemas econômicos relativos à bitributação nas relações internacionais e propor soluções para sua eliminação. ${ }^{232}$

A Comissão Europeia da OCDE, em julho de 2000, considerando que a determinação do local em que ocorrem as operações tributáveis provocava conflitos de competência entre os Estados-membros, manifestou, entre outras, a intenção de alterar o lugar em que se considera prestado o serviço, considerando conveniente fixar esse lugar no país do destinatário. As medidas foram materializadas por meio da Proposta do Conselho para alterar a Diretiva 77/388/CEE ${ }^{233}$, que trata da "harmonização das legislações dos Estados-membros respeitantes aos impostos sobre o volume de negócios”. ${ }^{234}$

Victor Uckmar, analisando a posição da OCDE em 2000, que coincidia com a indicada pela Comissão Europeia na referida Proposta de Diretiva em relação à tributação do comércio eletrônico, resumiu da seguinte forma as propostas apresentadas:

${ }^{230}$ Cf. LEE, Chang Hee, op. cit. (nota 215). Acesso em 6 de junho de 2012.

${ }^{231}$ O Bit Tax é um tributo proposto por vários países para incidir sobre o uso da Internet, segundo o volume de dados transferidos, cuja unidade seria o "bit".

${ }^{232}$ Cf. SCHOUERI, Luis Eduardo, op. cit. (nota 07), pp. 25/26.

${ }_{233}$ Diretiva 77/388/Conselho da Comunidade Europeia. Disponível em: < $\underline{\text { http://eur- }}$ lex.europa.eu/LexUriServ/LexUriServ.do?uri=CELEX:31977L0388:PT:HTML>. Acesso em 14 de junho de 2012.

${ }^{234}$ Exposição de motivos da Proposta de Diretiva do Conselho para alterar a Diretiva 77/388/CEE, no que diz respeito ao lugar da prestação de serviços. Disponível em: <http://eurlex.europa.eu/smartapi/cgi/sga doc?smartapi!celexplus!prod!DocNumber\&lg=pt\&type doc=COMfinal\& an doc $=2003 \&$ nu doc $=822>$. Acesso em 14 de junho de 2012. 
a) No setor da tributação indireta, é preciso concentrar todos os esforços na adequação dos impostos existentes, e mais especificamente do IVA, aos avanços do comércio eletrônico. Não são, portanto, levados em consideração impostos novos ou adicionais;

b) Uma operação cujo resultado seja colocar um produto à disposição do destinatário em forma digital, mediante uma rede eletrônica, é enquadrada, para fins de IVA, como uma prestação de serviços;

c) A legislação comunitária em matéria de IVA deveria assegurar que:

- os serviços, prestados mediante comércio eletrônico exclusivamente com tais meios, quando prestados para serem utilizados dentro da EU, sejam nela tributados, independentemente de sua origem;

- os mesmos serviços, prestados por operadores da EU para serem utilizados fora da EU, não sejam submetidos ao IVA na EU, mas que o IVA incidente nas operações anteriores seja dedutível. ${ }^{235}$

$\mathrm{Na}$ análise elaborada por Uckmar, percebe-se que a União Europeia defendia a tributação dos serviços prestados pela Internet no território de seus paísesmembros, adotando como elemento de conexão o local onde os serviços produzem sua "utilidade", vale dizer, no Estado de destino de tais serviços, isentando da tributação, inclusive, aqueles que produzirem seus efeitos fora dos territórios dos países-membros.

Em 7 de maio de 2002, o Conselho da União Europeia aprovou a Diretiva 2002/38/CE, alterando a Diretiva 77/388/CEE, com base nas propostas supramencionadas, trazendo medidas relativas ao comércio eletrônico. ${ }^{236}$

Os serviços prestados por via eletrônica consideram-se prestados no lugar do domicílio do tomador dos serviços ou de sua residência habitual, ${ }^{237}$ o que leva à tributação dos serviços importados por residentes nos países-membros da União Europeia e à isenção daqueles exportados a partir desses países. Os prestadores de serviços não residentes em países da Comunidade devem registrar-se perante um dos países-membros conforme um regime especial, pelo qual deverão optar, passando a cumprir todas as obrigações tributárias relativas ao IVA perante este país, que prestará contas aos demais países membros onde residem os tomadores de serviços, conforme declaração a ser apresentada periodicamente pelo prestador. ${ }^{238}$

${ }^{235}$ UCKMAR, Victor, Tributação do Comércio Eletrônico. Atualidades e Perspectivas, Tradução de Marco Aurélio Greco, In Direito e Internet - Relações Jurídicas na Sociedade Informatizada, Marco Aurelio 236 Greco e Ives Gandra da Silva Martins (coords.), São Paulo, Revista dos Tribunais, 2001, p. 255.

lex.europa.eu/LexUriServ/LexUriServ.do?uri=CELEX:32002L0038:PT:HTML>. Acesso em 13 de junho de 2012.

${ }^{237}$ Art. $9^{\circ}, \mathrm{n}^{\circ}$ 2, alínea “f”da Diretiva 77/388/CEE, com a redação determinada pela Diretiva 2002/38/CE.

${ }^{238}$ Art. $26^{\circ} \mathrm{C}$ da Diretiva 77/388/CEE, adicionado pela Diretiva 2002/38/CE. O mecanismo do prestador não residente foi regulamentado pelo Regulamento (CE) n. ${ }^{\circ}$ 1798/2003 de 7 de Outubro de 2003, publicado 
A aplicação destas disposições foi prorrogada até 31 de dezembro de 2006 pela Diretiva 2006/58/CE do Conselho, de 27 de junho de 2006.

A adoção pelos países-membros da Comunidade Europeia da regra relativa à cobrança do IVA de prestadores de serviço não residentes, privilegiando o princípio do destino, foi comentada por Chang Hee Lee:

Em relação à alocação de impostos sobre o consumo, os países avançados ainda aplicam a norma existente do princípio do destino, ainda que a norma interna dentro do Mercado Comum Europeu esteja tendendo mais à direção do princípio da origem. Existe um caso notável na aplicação da regra do princípio de destinação. Vigorando desde $1^{\circ}$ de julho de 2003, a medida da União Europeia permite aos países, ao invés de tentar inutilmente recolher os impostos dos consumidores finais de produtos digitais importados, obrigar os fornecedores não residentes na área da comunidade europeia a se registrar para pagar o Imposto sobre o Valor Adicionado (IVA) pelo fornecimento de produtos digitais a consumidores Europeus. ${ }^{239}$

A Diretiva 77/388/CEE, de 17 de maio de 1977, foi revogada pela Diretiva 2006/112/CE do Conselho, de 28 de novembro de 2006, que passou a regulamentar o IVA - Imposto sobre o Valor Adicionado, no âmbito da Comunidade Europeia.

A nova Diretiva manteve o sistema de tributação dos serviços prestados no local de residência do tomador, ou seja, na fonte dos rendimentos. Para tanto, foi preservado o sistema de identificação que determina o cadastramento prévio dos sujeitos passivos não estabelecidos na CE para que possam atuar naqueles países. De modo geral, os Estados-membros condicionam a autorização para que os sujeitos passivos não estabelecidos na Comunidade atuem e prestem serviços em seus territórios à obrigação prévia de comunicar ao Estado-membro de identificação o momento em que inicia ou cessa sua atividade, ou quando há a alteração de qualquer de seus dados cadastrais. O

no Jornal Oficial da Comunidade Europeia em 15.10.2003. O Regulamento $\mathrm{n}^{\circ} 1798$ está disponível em: <http://eur-lex.europa.eu/LexUriServ/LexUriServ.do?uri=OJ:L:2003:264:0001:0011:PT:PDF>. Acesso em 15 de junho de 2012. Cf. SILVA, Emerson Drigo, op. cit. (nota 102), p. 91.

239 Cf. LEE, Chang Hee, op. cit. (nota 215). Acesso em 6 de junho de 2012. No original: "Regarding international allocation of consumption tax revenue, advanced countries still endorse the existing norm of the destination principle, although the internal norm within the EU Common Market comes ever closer to the origin principle. A note-worthy development exists in the enforcement of the destination principle. Effective July 1, 2003, the European Union will, rather than vainly trying to collect tax from final consumers for imported digital products, obligate non-EU suppliers to register and pay VAT to the extent they provide digital products to EU consumers as aforementioned". 
sistema de identificação atribui ao sujeito passivo não estabelecido um número de identificação individual para efeitos do IVA. ${ }^{240}$

Quando os prestadores de serviço não se encontram estabelecidos no Estado-membro em que o IVA é devido, a norma permite que os Estados instituam a responsabilidade ao destinatário do serviço, além de autorizar também que sujeitos passivos não estabelecidos no Estado-membro em que o IVA é devido designem um representante fiscal como devedor do imposto.

Os serviços prestados por via eletrônica, listados no Anexo II da norma, continuam submetidos ao regime especial, estabelecido no artigo 359 e seguintes. ${ }^{241}$ São abrangidos pelo regime especial, entre outros, os serviços de fornecimento de programas informáticos e respectivas atualizações, o fornecimento de imagens, textos e informações e disponibilização de base de dados, o fornecimento de música, filmes e jogos, incluindo jogos de azar e a dinheiro, e de emissões ou manifestações políticas, culturais, artísticas, desportivas, científicas ou de lazer, a prestação de ensino à distância, a domiciliação de páginas web.

\subsection{A Tributação nos Tratados Internacionais}

A doutrina nacional pouco tem se debruçado sobre o tema da tributação do comércio eletrônico, ao passo que no campo internacional, muitos Estados e organizações internacionais inserem o tema há anos em suas pautas de discussão.

Neste sentido, as regras utilizadas para a tributação do comércio eletrônico no cenário internacional, ainda que voltadas preponderantemente aos rendimentos gerados em suas operações, poderão fornecer subsídios na identificação de elementos de conexão ou outros conceitos aplicáveis na tributação do ISS no comércio eletrônico, pelos municípios brasileiros. Entre os conceitos utilizados na tributação internacional, o de "estabelecimento permanente" guarda estreita relação de similitude com o conceito nacional de "estabelecimento prestador", de modo que os estudos e

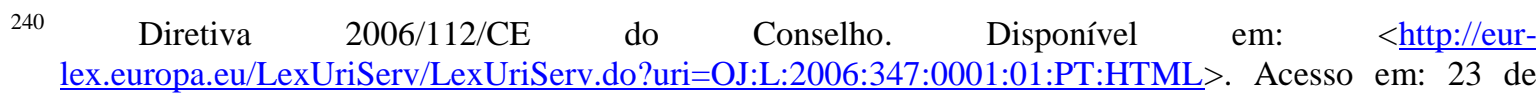
outubro de 2012.

${ }^{241}$ Idem, ibidem. Acesso em 23 de outubro de 2012.
} 
aprimoramentos atingidos no campo internacional poderão ser de grande proveito na tributação dos serviços no Brasil.

No direito internacional tributário são celebradas convenções ou tratados que definem normas de reconhecimento de competência, tendo por escopo a repartição das pretensões impositivas aos Estados envolvidos, visando a evitar a bitributação e os conflitos de competência entre eles. De um modo geral, estes tratados são negociados com base em modelos preestabelecidos.

Desta forma, as atuais normas de tributação internacionais, introduzidas por tratados e acordos, materializam as convenções pactuadas entre as nações relativas à repartição do poder de tributar a renda oriunda dos negócios que envolvem mais de uma nação, em especial do comércio e dos investimentos.

Dentre os modelos atualmente existentes para tratados internacionais Convenção Modelo da ONU - Organização das Nações Unidas, Convenção Modelo dos Países do Pacto Andino, Convenção Modelo dos Estados Unidos, entre outros - o modelo utilizado na maior parte dos tratados internacionais firmados contra a dupla tributação tem sido aquele da OCDE - Organização para a Cooperação e Desenvolvimento Econômico, como é o caso de todos os acordos firmados pelo Brasil. Por este motivo, nosso estudo será centrado nas regras contidas na Convenção Modelo da OCDE - CM-OCDE, em especial nos conceitos aplicados às convenções tributárias contra a dupla tributação.

A OCDE tem sido o grande fórum dos países europeus nas discussões relativas ao e-commerce, sendo que os estudos da organização foram iniciados com uma análise prévia dos conceitos que legitimam a tributação na fonte dos não-residentes, como o conceito de "estabelecimento permanente", a caracterização da renda e os elementos de conexão.

O princípio da tributação no país da residência e o princípio da tributação no país da fonte representam interesses contrapostos e tendências antagônicas, respectivamente, dos países desenvolvidos e em desenvolvimento. ${ }^{242}$

O critério da tributação na residência beneficia os países mais desenvolvidos, que tributam a renda no local de residência do contribuinte (sede das empresas) negando, em regra, a existência de um "estabelecimento permanente" no país de fonte. O princípio, no entanto, seria totalmente destituído de fundamentos teóricos, não 
existindo, segundo Schoueri, motivo para condicionar a tributação dos rendimentos na fonte à existência de uma estrutura física, já que hoje, com o desenvolvimento das tecnologias da comunicação e meios de transporte, boa parte das atividades que geram renda prescinde de uma base física. ${ }^{243}$

A tributação das transações do comércio eletrônico exclusivamente no Estado da residência do contribuinte, com a exclusão do critério da tributação na fonte dos rendimentos, poderia ainda favorecer a transferência de empresas comerciais para os paraísos fiscais, o que pode ser potencializado quando se trata de atividades relacionadas ao "comércio eletrônico". 244

O conceito de "residência" para fins dos tratados e acordos é definido pelo artigo $4^{\circ}$ da CM-OCDE, que estabelece que a expressão "residente de um Estado contratante" significa "qualquer pessoa que, por virtude da legislação desse Estado, está aí sujeita a imposto devido ao seu domicílio, à sua residência, ao local de direção ou a qualquer outro critério de natureza similar". ${ }^{245}$

Por outro giro, o conceito de "residência", utilizado por praticamente todos os países do mundo como critério para tributar, pode ser entendido como a "conexão pessoal”, seja da pessoa física (residência, domicílio) ou jurídica (local da incorporação ou administração efetiva), com o território de determinado país.

Já a "conexão territorial” justifica a tributação pela oferta das condições físicas necessárias ao contribuinte para que possa auferir determinada renda, garantindo sua produção, manutenção e seu uso por meio do consumo. Desta forma, admite-se a tributação de um não-residente em determinado país quando a fonte de sua renda localizase dentro do território deste país, ou quando este ali possua, por exemplo, bens imóveis.

De maneira sucinta, as regras internacionais podem ser assim descritas: (i) cada país tem o direito de tributar os rendimentos auferidos pelas atividades desenvolvidas em seu território; (ii) os países têm ainda o direito de tributar os rendimentos obtidos por seus residentes, pessoas físicas ou jurídicas, independentemente de onde o rendimento foi gerado; e (iii) para evitar a cumulação das duas regras anteriores, que

${ }^{243}$ Cf. SCHOUERI, op. cit. (nota 115), p. 48, nota $\mathrm{n}^{\circ} 22$.

${ }^{244}$ Cf. Idem, ibidem, p. 49.

${ }^{245}$ Art. $4^{\circ}$ da Convenção Modelo da OCDE. Disponível em: $<$ http://info.portaldasfinancas.gov.pt/NR/rdonlyres/479C17F1-84B8-45F8-805673B300425BAD/0/CDT_Modelo_OCDE.pdf>. Acesso em 12 de outubro de 2012. 
levaria à bitributação dos rendimentos ${ }^{246}$, o país da fonte tributa de forma limitada, e o país da residência concede-lhe a primazia na tributação de determinados itens. O país da residência pode conceder créditos relativos aos valores pagos nos países da fonte para serem abatidos na origem, ou pode optar por até mesmo isentar o rendimento auferido no exterior. $^{247}$

Portanto, para evitar ou atenuar a bitributação, os países da fonte limitam sua tributação e aqueles da residência deixam de tributar pela concessão de créditos, reconhecendo o direito dos países da fonte. A dificuldade do sistema estaria em estabelecer os limites adequados para os países da fonte, o que é feito por meio da classificação da renda em questão, em função de seu caráter econômico, distinguindo a origem entre trabalho e capital, que eram os dois fatores de produção na economia clássica. Baseados nesta qualificação, a renda derivada do trabalho ou serviço pode ser atribuída ao país da fonte onde estes são executados, ou seja, no local onde está localizada a fonte desta renda.

A renda de royalties deve ser prioritariamente tributada no país da residência de seu beneficiário, assim como o lucro dos negócios, admitindo-se, contudo, sua tributação no país da fonte caso nele se constate um estabelecimento permanente ao qual será imputado este lucro.

Neste sistema internacional de tributação, associam-se à dicotomia "fonte e residência", respectivamente, os princípios da territorialidade e da universalidade. É que os países desenvolvidos que tributam a renda tendo como parâmetro a residência das pessoas, o fazem em bases universais, vale dizer, consideram todo o patrimônio do contribuinte, sem possibilidade de fracioná-lo. Os países da fonte, por seu turno, para que possam tributar determinada renda devem estabelecer com esta uma conexão territorial, em sentido real.

Segundo Schoueri, a polêmica não se justifica visto que tanto "fonte" quanto "residência" representam diferentes aspectos da territorialidade: o princípio da fonte representaria a territorialidade em sentido real, enquanto o princípio da residência estaria relacionado à territorialidade em sentido pessoal. Ademais, enquanto

\footnotetext{
${ }^{246}$ Alcides Jorge Costa debruçando-se sobre o tema da bitributação concluiu que a melhor definição para a expressão é a de DORN, para quem "ocorre bitributação internacional quando impostos semelhantes são exigidos da mesma pessoa, em virtude do mesmo objeto, pelo mesmo período de tempo, por força do exercício de duas ou mais soberanias fiscais". Apud LEONARDOS, Gabriel L., op. cit. (nota 152), p. 16.

${ }^{247}$ Cf. LEE, Chang Hee, op. cit. (nota 215). Acesso em 6 de junho de 2012.
} 
territorialidade significa a ligação de uma situação a determinado território, universalidade refere-se à extensão do poder de tributar determinada renda. ${ }^{248}$

\subsection{A Qualificação da Renda do Comércio Eletrônico}

No comércio eletrônico, três são os desafios que se impõem aos países para a tributação na fonte: (i) a determinação da "presença tributável" que confere ao país o direito subjetivo de tributar determinada operação; (ii) a determinação da fonte de renda e (iii) a categorização desta renda. ${ }^{249}$

Segundo o professor Chang Hee Lee ${ }^{250}$, as atuais normas de tributação relativas à qualificação das rendas foram concebidas a partir de conceitos clássicos, representados na economia pela dicotomia "capital e trabalho", revelada em termos jurídicos como "propriedade e serviço". Estes conceitos, que consideravam os dois fatores de produção na economia clássica - "capital e trabalho" - seriam inaplicáveis ao mundo digital.

O próprio conceito de "propriedade" tem evoluído, deixando de designar somente bens tangíveis que correspondem a um trabalho humano. $\mathrm{O}$ trabalho intelectual vem assumindo posição significativa na produção humana e as tecnologias digitais tiveram papel decisivo para que os resultados obtidos com este tipo de trabalho mental possam ser preservados (save) e reutilizados. Desta forma, há hoje mídias que incorporam trabalho intelectual, como, por exemplo, os softwares ou programas, que podem ser transmitidas através de fios, ou mesmo pelo ar, e que são tão ou mais importantes que os bens tangíveis. Segundo o professor coreano, na medida em que o produto do trabalho humano pode ser salvo e reutilizado, ele se ajusta perfeitamente à definição econômica de "capital", seja tangível ou não, enquanto fator de produção criado por seres humanos, tornando assim irrelevante a distinção entre capital e trabalho. ${ }^{251}$

Para ilustrar a tese, Chang propõe como exemplo uma situação em que duas emissoras de televisão transmitem o mesmo show de um cantor, cujas remunerações serão qualificadas de forma distinta, ou seja, os rendimentos teriam naturezas econômicas

\footnotetext{
${ }^{248}$ Cf. SCHOUERI, Luis Eduardo, op. cit. (nota 115), p. 94.

${ }^{249}$ Cf. VASCONCELOS, Roberto de França, op. cit. (nota 113), p. 118.

${ }^{250}$ Cf. LEE, Chang Hee, op. cit. (nota 215). Acesso em 6 de junho de 2012.

${ }^{251}$ Cf. Idem, ibidem. Acesso em 6 de junho de 2012.
} 
diversas. A emissora que transmite o show ao vivo irá remunerar a apresentação do cantor de forma que a renda será qualificada como "serviço"; já o pagamento efetuado pela segunda emissora, que comprou a gravação e a reproduziu minutos depois, será considerado como royalty, já que adquiriu os "direitos” para reprodução do espetáculo. Tal situação demonstraria que a diferenciação seria uma formalidade legal, e que isto não teria o condão de alterar sua substância econômica.

No entanto, os fatos jurídicos subjacentes a cada uma das situações são totalmente distintos, senão vejamos: o pagamento efetuado ao cantor pela apresentação ao vivo refere-se ao fato jurídico de prestar serviço (cantar músicas). Já o pagamento efetuado pela emissora que reproduziu o show não corresponde a qualquer trabalho ou serviço, mas remunera os direitos na reutilização de um serviço que foi gravado e poderá ser reproduzido infinitamente. Note-se que o artista pode ter convencionado uma cessão total de seus direitos à primeira emissora, de modo que a segunda emissora pagará os honorários à cessionária.

Outro exemplo aduzido pelo autor é a aquisição de cem disquetes com cópias de um software ou de apenas um disquete com o direito de reproduzi-lo cem vezes; economicamente não há qualquer diferença entre as duas aquisições, que, no entanto, à luz das regras vigentes de tributação, são distintas. A renda da aquisição das cem cópias é qualificada como lucro do negócio e aquela relativa às licenças será qualificada como royalties.

A solução apontada por Chang seria a redução das categorias de rendas oriundas de aluguel e a criação de distinções adicionais para as rendas geradas pelo comércio eletrônico. Neste diapasão, as rendas de prestação de serviços seriam classificadas em duas subcategorias: os serviços que envolvem ação humana permaneceriam submetidos às atuais regras de tributação, considerando-se como fonte o local onde são desempenhados, enquanto os serviços meramente mecânicos, como, por exemplo, a prestação de informação acessada à distância, teriam sua renda tributada considerando-se a fonte, segundo as regras que regulam a exploração da propriedade pessoal tangível e intangível. ${ }^{252}$

${ }^{252}$ Cf. DOERNBERG, Richard L., HINNEKENS, Luc, Eletronic Commerce and International Taxation, Apud VASCONCELOS, Roberto de França, op. cit. (nota 113), p. 337. 


\subsection{A Determinação da Fonte e da Residência no $E$-commerce}

A definição da fonte dos rendimentos em função do conceito de "estabelecimento permanente" no comércio eletrônico torna-se insuficiente em função de certas características deste tipo de transação, como a mobilidade e a natureza intangível de muitas operações, que denotam a necessidade de sua recontextualização.

A problemática na tarefa de localizar as transações eletrônicas e empresas virtuais para fins de tributação no país "da fonte" é também inerente à determinação da "residência" das sociedades, principalmente daquelas empresas que realizam negócios virtuais que não ocorrem no mundo físico convencional.

Com a manipulação do conceito de residência corporativa, surge a possibilidade da dupla "não tributação", viabilizada pela presença dos "paraísos físcais", que oferecem benefícios fiscais ou a total isenção de impostos para atrair para si uma parte da renda oriunda destas transações.

A tributação no local da residência da pessoa jurídica é definida, em regra, em função da localização da administração efetiva ou com base no país sob cujas leis se constituiu a sociedade; tais diretrizes, de certa forma, privilegiam também uma presença tributável, sendo incompatíveis com a realidade do "comércio eletrônico". Na transação eletrônica, como a administração pode ser feita à distância, dispensando a presença física dos administradores, a individualização da sede da direção efetiva de uma empresa poderá ser inviabilizada. ${ }^{253}$

A utilização de videoconferência ou outros recursos de telecomunicação permite que a gestão societária seja feita sem a presença física de administradores, possibilitando que estes residam inclusive em diferentes jurisdições, o que leva os Estados a repensar as regras para a definição do local de residência das empresas.

A Holanda, por exemplo, para definir se uma sociedade possui residência em seu território analisa e considera as seguintes circunstâncias: (i) local das reuniões; (ii) localização do principal edifício de escritório; (iii) o lugar onde os livros físcais são mantidos; (iv) a moeda utilizada na contabilidade da empresa; (v) o local onde os documentos financeiros são mantidos; (vi) o lugar onde a companhia é registrada e (vii) o local onde os contratos sociais são depositados. Outra alternativa para a fixação da

${ }^{253}$ Cf. DOERNBERG, Richard L., op. cit. (nota 88), p. 32. 
residência, em função dos novos recursos tecnológicos, seria considerar a residência dos diretores ou administradores, ou ainda a residência de um número percentual específico de acionistas ou funcionários, o que seria mais difícil de manipular do que o local onde são tomadas as decisões ou onde ocorrem as reuniões. ${ }^{254}$

As soluções apontadas por especialistas, no sentido da utilização exclusiva do país da residência para fins de tributação, não preveem qualquer tipo de compensação aos países da fonte pela potencial perda de receita. Doernberg ${ }^{255}$, no entanto, já em 1998, propunha a manutenção das regras de tributação, com a adoção de medidas compensatórias aos países "fonte”, assim entendidos aqueles países onde se localiza a base de clientes.

Nas operações tradicionais, os bens são produzidos nos Estados mais desenvolvidos, que permanecem com as receitas oriundas do lucro na fabricação destes bens. Os produtos serão, então, vendidos naqueles Estados em desenvolvimento que, por seu turno, lucram com o marketing e a venda destes produtos, havendo, desta forma, um equilíbrio nas transações internacionais.

Nas transações digitais, no entanto, além da riqueza obtida com a produção dos bens, é possível ainda que a criação (programação) da página web, que possibilitará também as funções de comercialização, venda e pagamento, ocorra no local onde a empresa está estabelecida (residência). Desta maneira, os estados importadores irão contribuir somente com os clientes, não havendo mais qualquer presença tributável, como "estabelecimento permanente" ou agente de vendas, gerando a dúvida sobre onde é gerada a riqueza. ${ }^{256}$

Neste cenário, corre-se o risco dos Estados importadores passarem a adotar uma visão ampliada dos conceitos tributários, como, por exemplo, configurando um servidor de dados como um "estabelecimento permanente", ou privilegiarem impostos que incidam sobre o consumo, como o IVA, e não onde a riqueza é criada, adotando regimes fiscais que lhe sejam mais benéficos e pondo em risco o atual equilíbrio internacional.

\footnotetext{
${ }^{254}$ Cf. VASCONCELOS, Roberto de França, op. cit. (nota 113), p. 127.

${ }^{255}$ Cf. DOERNBERG, Richard L., op. cit. (nota 88), p. 10.

${ }^{256}$ Cf. Idem, ibidem, p. 12.
} 


\subsection{O Comércio Eletrônico na Convenção Modelo da OCDE}

Até o presente momento, a OCDE não promoveu qualquer alteração nos artigos de sua Convenção Modelo em função do "comércio eletrônico", limitando-se a adicionar alguns comentários relativos a estas operações, em especial as relativas ao conceito de "estabelecimento permanente" e de royalty (art. $5^{\circ}$ e 12 ) e as que envolvem software (art. 12).

No Modelo da OCDE, o artigo $5^{\circ}$ define o conceito de "estabelecimento permanente" e o artigo 12 contempla as remunerações de qualquer natureza devidas pelo uso ou pela concessão do direito de uso (i) de direitos autorais sobre obras literárias, artísticas ou científicas, incluindo os filmes cinematográficos, (ii) de patentes, marcas de indústria ou de comércio, desenhos ou modelos, planos, fórmulas ou processos secretos e (iii) de informações relativas à experiência adquirida no setor industrial, comercial ou científico. ${ }^{257}$

Os Comentários Oficiais à Convenção Modelo servem como um guia amplamente aceito na aplicação dos acordos de bitributação e têm por objetivo a interpretação daquele Modelo e a resolução de disputas acerca da questão. No entanto, não são normas jurídicas, nem possuem efeito vinculante para os países que não são membros daquela organização, como o Brasil, que, no entanto, utiliza em suas convenções o modelo por ela elaborado. ${ }^{258}$

Um artigo que poderia fortalecer a tese da tributação na fonte é o artigo 17 da Convenção Modelo, que poderia constituir um argumento favorável àqueles que adotam a tributação na fonte de produção dos rendimentos. O artigo, sobre o rendimento de artistas e atletas, autoriza a tributação pelo país da fonte, mesmo sem a existência de um estabelecimento permanente, já que estes profissionais prescindem de qualquer estrutura física fixa para desempenhar suas atividades.

${ }^{257}$ No original: "The term royalties as used in this article means payments of any kind received as a consideration for the use of, or the right to use, any copyright of literary, artistic or scientific work including cinematograph films, any patent, trade mark, design or model, plan secret formula or process or for information concerning industrial, commercial or scientific experience". Convenção Modelo OCDE - Artigo 12 - Item 2. Disponível em: <http://www.oecd.org/dataoecd/46/32/1923380.pdf >. Acesso em 24 de abril de 2010.

258 Cf. BELLAN, Daniel Vitor, Interpretação dos Tratados Internacionais em Matéria Tributária, in TORRES, Heleno (coord.), Direito Tributário Internacional, São Paulo, Quartier Latin, 2005, Volume III, pp. 646-653. 


\subsubsection{Comentários à CM-OCDE: Servidor de Dados}

Os comentários relativos ao comércio eletrônico inseridos na Convenção Modelo analisam, entre as possibilidades de configuração de um "estabelecimento permanente" em determinado país, aquela da utilização de equipamentos de informática (servidor de dados) em operações de comércio eletrônico. ${ }^{259}$

Estes comentários, introduzidos na Convenção Modelo da OCDE sob o título Electronic Commerce, correspondem aos itens 42.1 a 42.10, referentes ao parágrafo $7^{\circ}$ do artigo $5^{\circ}$, que trata do conceito de "estabelecimento permanente", e foram adotados pelo Conselho da OCDE em janeiro de 2003. ${ }^{260}$

Espanha e Portugal, que não consideram a presença física como um requisito para configurar um "estabelecimento permanente" no contexto do comércio eletrônico, mantêm certas reservas aos mencionados comentários. ${ }^{261}$

De modo geral, os comentários recomendam que um equipamento de informática automatizado (servidor), independentemente da existência ou não de pessoal da empresa proprietária do equipamento operacionalizando-o, somente será considerado um "estabelecimento permanente" em condições excepcionais, para fins de percussão tributária no país em que estiver situado, relativa aos rendimentos oriundos das operações por ele intermediadas. Para que se caracterize como tal, é necessário que o servidor esteja operando nos limites geográficos de determinado território "por um período de tempo suficiente", considerando-se, desta forma, fixo.

Em relação aos sites na Internet, os comentários consideram que como não se tratam de bens corpóreos, mas uma combinação de software e dados eletrônicos, não havendo um local de trabalho ou uma instalação propriamente ditos, as páginas eletrônicas não podem por si só configurar um “estabelecimento prestador". Por outro lado, um equipamento automatizado no qual o site fica armazenado, e através do qual é acessado, é um equipamento que tem uma localização física podendo constituir um "lugar fixo de negócios" da empresa que opera o servidor. Note-se que o estabelecimento

259 Cf. comentário 42.1 da CM-OCDE. Disponível em: <http://www.keepeek.com/Digital-AssetManagement/oecd/taxation/model-tax-convention-on-income-and-on-capital-2010 9789264175181-en>. Acesso em 15 de outubro de 2012.

${ }^{260}$ Os comentários foram incluídos na CM-OCDE, por meio do relatório The 2002 Updat To The Model Tax Convention. Ibidem. Acesso em 15 de outubro de 2012.

${ }^{261}$ Cf. CUELLO, Rafael Oliver, op. cit.(nota 224). Acesso em 29 de maio de 2012. 
configurado pelo servidor enquanto equipamento é aquele da empresa que opera o servidor de dados.

A distinção entre a empresa representada no site e a responsável pelo servidor no qual o site está hospedado é importante para uma empresa que exerce suas atividades por meio de um web site. Os contratos de hospedagem de site, em regra, não disponibilizam um servidor dedicado exclusivamente a determinada empresa, assim como não definem sua localização; paga-se por espaço de armazenagem em disco e, mesmo que a empresa tenha sido capaz de determinar que seu site deve ser hospedado em um servidor específico, em um determinado lugar, não é possível considerar que ela tenha adquirido um "lugar de negócios" em virtude do contrato de hospedagem.

No entanto, se uma empresa exercer suas atividades por meio de um web site e detiver um servidor de dados à sua disposição, adquirido ou arrendado, operando o equipamento no qual o site está armazenado, e utilizando o local onde o servidor está instalado, poderá configurar um "estabelecimento permanente", desde que presentes os outros requisitos contidos no artigo $5^{\circ}$ da Convenção Modelo.

Um dos requisitos para que um equipamento de informática constitua um "estabelecimento permanente" é que ele esteja afixado em determinado lugar por um período de tempo suficiente para corresponder ao conceito de "fixo" na acepção do parágrafo primeiro.

Outro fator relevante é se o negócio da empresa é total ou parcialmente desenvolvido no local onde se localizam os equipamentos, como o servidor de dados; segundo o comentário 42.5, a análise deve ser casuística, investigando-se se todas ou a maior parte das atividades da empresa são desempenhadas por meio destes equipamentos.

Uma importante ressalva é que não se exige a presença de pessoal da empresa no local onde se localiza o equipamento, podendo se configurar um "estabelecimento permanente" mesmo sem a presença de representantes ou agentes da empresa. Tal disposição aplica-se não somente em relação ao comércio eletrônico, mas também a outras atividades que utilizam equipamentos que funcionam de forma automática como, por exemplo, equipamentos de bombardeamento automático utilizado na exploração de recursos naturais.

De grande relevância também no comércio eletrônico, em relação às atividades desenvolvidas pelos equipamentos, são os conceitos de "atividades preparatórias ou auxiliares", abrangidas pelo parágrafo $4^{\circ}$ do artigo $5^{\circ}$. A análise, que deve ser casuística, 
deve considerar as diversas funções desempenhadas por uma empresa por meio desses equipamentos, distinguindo aquelas que constituem em si mesmas parte essencial e significativa do objeto social de uma empresa daquelas que encerram o caráter de meras atividades preparatórias.

Os comentários consideram como atividades preparatórias ou auxiliares, entre outras: o fornecimento de link de comunicação, a publicidade de bens ou serviços, a veiculação de informação por meio de um servidor espelho para fins de segurança e eficiência, a captação de dados de mercado e o fornecimento de informações. ${ }^{262}$

No entanto, se tais funções constituem em si mesmas parte essencial e significativa da empresa, ou se as outras funções da empresa são desempenhadas por meio de equipamentos de informática, pode-se considerar que tais atividades vão além do conceito contido no parágrafo $4^{\circ}$, constituindo um local fixo de negócios da empresa e configurando, portanto, um "estabelecimento prestador".

As funções de uma empresa podem ser qualificadas como principais ou auxiliares em função da natureza das atividades desenvolvidas por ela, sendo que muitas empresas hoje operam servidores para abrigar seu web site e também fornecer hospedagem em seus equipamentos a outras empresas. Para estas empresas, a operação de seus equipamentos é parte essencial de seu objeto social, não podendo ser considerada como atividade preparatória ou auxiliar.

Diverso, no entanto, é o caso de uma empresa que comercializa suas mercadorias usando um web site na Internet; o negócio da empresa não é a operacionalização e gerenciamento de servidores, e o fato de utilizar-se de um equipamento fixo em determinado local não é suficiente para concluir que tais atividades não sejam preparatórias ou auxiliares.

Por outro giro, deve-se cotejar a natureza das atividades exercidas no local onde estão os equipamentos de informática com o negócio principal desenvolvido pela empresa; caso essas atividades sejam auxiliares ou preparatórias, o local dos equipamentos não pode ser considerado como um “estabelecimento prestador".

Se, no entanto, voltando ao exemplo da empresa que comercializa mercadorias pela Internet, as atividades típicas relacionadas com a venda são realizadas no local onde estão os equipamentos de informática, como a conclusão do contrato com o

${ }^{262}$ Cf. comentário 42.7 da CM-OCDE. Op. cit. (nota 259). Acesso em 15 de outubro de 2012. 
cliente, o processamento do pagamento e a entrega dos produtos, são todas executadas de forma automática por meio daqueles equipamentos, resta evidenciado que estes equipamentos que hospedam o web site da empresa configuram, na verdade, um “estabelecimento permanente'. ${ }^{263}$

Os Internet service provider (ISP) que, como vimos, podem configurar um "estabelecimento permanente", costumam prestar serviços de hospedagem de sites de outras empresas em seus servidores. Neste caso, o item 42.10 discute se os ISPs poderiam configurar-se como "agentes" das empresas que hospedam sites em seus servidores, nos termos do disposto no parágrafo $5^{\circ}$ do artigo. No entanto, a aplicação da referida norma ficaria afastada, já que os ISPs não possuem autonomia para concluir contratos em nome destas empresas e não costumam celebrar tais contratos. Ademais, um web site por meio do qual uma empresa atua não pode ser considerado uma "pessoa", conforme definido no artigo $3^{\circ}$ da Convenção Modelo.

Tais diretrizes dificultam (se não chegam a impedir) que os países da fonte dos rendimentos adquiram o direito subjetivo de tributar os rendimentos das operações do "comércio eletrônico". De forma resumida, estes países somente estariam autorizados a tributar estas operações quando os servidores atendessem concomitantemente aos seguintes requisitos: (i) estar afixados em determinado território, por um período de tempo suficiente; (ii) as atividades da empresa sejam total ou prioritariamente desenvolvidas no equipamento; e (iii) que as atividades desenvolvidas no servidor não se configurem como preparatórias ou auxiliares, sendo dispensável a presença de representantes ou agentes da empresa operando o equipamento.

No que tange à página eletrônica por meio da qual se desenvolvem as operações de comércio eletrônico, somente será considerada como um "estabelecimento permanente" quando estiver hospedada em um servidor de dados próprio, locado ou recebido em comodato, operado por pessoal próprio, física ou remotamente, e desde que permaneça o equipamento por um período de tempo suficiente para que seja considerado fixo.

${ }^{263}$ Cf. comentário 42.9 da CM-OCDE. Op. cit. (nota 259). Acesso em 15 de outubro de 2012. 


\subsubsection{Comentários à CM-OCDE relativos à Prestação de Serviços}

Alguns comentários à Convenção Modelo da OCDE tratam de assuntos vinculados à tributação de serviços. Até 29 de abril de 2000, a prestação de "serviços pessoais independentes" era tratada pelo artigo 14 da Convenção Modelo, quando foi então suprimido. O item 77 dos Comentários consigna que "o efeito da eliminação do art. 14 é que o rendimento proveniente de serviços profissionais ou outras atividades de caráter independente é agora tratado nos termos do art. 7 como lucro de empresa". ${ }^{264}$

Entendeu-se que, os conceitos aplicáveis às empresas em geral, como "estabelecimento permanente", "local da atividade da empresa", entre outros, são apropriados também às prestações de serviços ainda que possuam caráter pessoal.

Os comentários 42.11 a 42.48 , relativos ao artigo $5^{\circ}$ da CM-OCDE, abrem um novo capítulo referente à tributação dos serviços e foram adicionados, em 17 de julho de 2008, ao relatório intitulado The 2008 Update to The Model Tax Convention, adotado pelo Conselho da OCDE naquela data. ${ }^{265}$

De modo geral, os comentários referem-se à aplicação do conceito de "estabelecimento permanente" na tributação dos serviços, impondo à prestação de serviço os mesmos princípios aplicáveis a todas as atividades de negócios: os lucros dos serviços realizados no território de um Estado contratante, por uma empresa estabelecida em outro Estado, somente serão tributados naquele Estado, se houver, ou se configurar, um “estabelecimento permanente". Alguns serviços constituem exceções, como, por exemplo, os abrangidos pelo artigo $8^{\circ}$ (navegação marítima, interior e aérea) e pelo artigo 17 (artistas e desportistas - atividades pessoalmente exercidas) e possuem regras próprias.

O principal problema nestas regras é que os critérios para a configuração de um "estabelecimento permanente" são basicamente temporais, o que pode levar as empresas a planejar a duração de suas atividades por meio do dimensionamento de suas equipes ou equipamentos, de modo a não configurar uma base fixa em determinado local, esquivando-se da tributação no local em que prestam os serviços. É certo que podem ocorrer circunstâncias inesperadas que levem a empresa prestadora a permanecer por mais

\footnotetext{
${ }^{264}$ Item 77 dos Comentários da CM-OCDE. Op. cit. (nota 259). Acesso em 15 de outubro de 2012.

${ }^{265}$ As alterações introduzidas em julho de 2008 constam do documento intitulado The 2008 Update to The Model Tax Convention. Disponível em: <http://www.oecd.org/tax/taxtreaties/41032078.pdf>. Acesso em 15 de outubro de 2012.
} 
tempo que o desejado no local da prestação do serviço, mas, na maioria dos casos, com um planejamento adequado é possível evitar a tributação dos serviços "na fonte".

Além disto, a inexistência de um "estabelecimento permanente" formal no país da fonte pode levar a dificuldades no ajuste do tributo recolhido naquele local com o devido no local da residência, já que não existiriam registros contábeis e ativos associados àquele estabelecimento e nem mesmo um agente que possa cumprir com requisitos de informação e coleta.

Alguns países são relutantes em aceitar a tributação exclusiva no país da residência, quando os serviços sejam de fato prestados naquele Estado, mas não se configure um estabelecimento prestador nos termos das regras vigentes. Estes países propõem mudanças no artigo $5^{\circ}$ para garantir o direito à tributação na fonte pela atribuição "em certas circunstâncias" dos lucros de serviços prestados em determinado território a esse Estado, sobrepondo-se a regra do "local da efetiva prestação dos serviços" àquela do “estabelecimento permanente". ${ }^{266} \mathrm{O}$ direito interno de muitos países admite a tributação dos serviços no local da efetiva prestação, mesmo inexistindo uma base física naquele território.

Neste diapasão, os Estados ficam ainda mais apreensivos em relação àqueles serviços que dispensam um local fixo de trabalho no território do Estado contratante para desempenhar um nível substancial de atividades. Ademais, dificuldades administrativas dos Fiscos na compensação de impostos não justificam que se exclua dos Estados em que se desenvolvem os serviços o direito de tributar o lucro de tais operações em função da inexistência de uma base física. ${ }^{267}$

Por outro lado, todos os países-membros da OCDE pactuaram no sentido de não atribuir direitos de tributação na fonte sobre os rendimentos provenientes da prestação de serviço realizada por um "não residente" no território de um Estado. Todas as convenções até então celebradas acatam estas regras e o fato de o tomador dos serviços ser residente de um Estado, ou o resultado do serviço ter sido obtido neste Estado, não constitui nexo suficiente para justificar a atribuição do direito de tributar a renda dos serviços a um Estado.

É consenso entre os Estados que não é permitido a um país tributar os lucros de serviços realizados em seu território, em determinadas circunstâncias, como, por

${ }^{266}$ Item 42.14 dos Comentários da CM da OCDE. Op. cit. (nota 259). Acesso em 15 de outubro de 2012.

${ }^{267}$ Cf. item 42.16 e 42.17 da CM-OCDE. Ibidem. Acesso em 15 de outubro de 2012. 
exemplo, quando os serviços são prestados durante um período de tempo muito curto, ou quando não houver um nível mínimo de presença física naquele país. O comentário 42.23 traz exemplos de situações em que os Estados estariam "livres" para dispor em acordos bilaterais, exceções ou disposições para configurar um "estabelecimento permanente".

Mesmo com a inclusão dos comentários ao artigo $5^{\circ}$ que auxiliam na aplicação e interpretação do conceito de "estabelecimento permanente", muitos Estados, em especial aqueles em desenvolvimento, seguem questionando os critérios fixados nas convenções contra a bitributação e solicitando alterações naquelas disposições. Neste sentido, a Comissão de Assuntos Fiscais abriu à discussão pública em 2011 uma proposta elaborada por um grupo de trabalho em relação à interpretação e aplicação da definição de "estabelecimento permanente", intitulado Interpretation and Application of Article 5 (Permanent Establishment) of The OCDE Model Tax Convention. ${ }^{268}$

\subsection{A Lei Modelo sobre Comércio Eletrônico da ONU}

A Comissão de Direito Comercial Internacional da ONU (UNCITRAL), convencida de que a "elaboração de uma lei modelo que facilite o uso do comércio eletrônico e seja aceitável para Estados que tenham sistemas jurídicos, sociais e econômicos distintos poderia contribuir de maneira significativa ao estabelecimento de relações econômicas internacionais harmoniosas", editou a Lei Modelo sobre Comércio Eletrônico, que foi aprovada em 1996 pela Assembleia Geral do organismo, cuja adoção é recomendada aos países membros. ${ }^{269}$

A norma, que visa à uniformização de regras sobre o comércio eletrônico nas diversas legislações nacionais, traz previsão específica dos deveres de conduta decorrentes da boa-fé objetiva em matéria de negócios concluídos por meio eletrônico.

O modelo veicula inicialmente a definição de conceitos como "mensagem eletrônica" e "intercâmbio eletrônico", além de definir parâmetros para o reconhecimento jurídico das mensagens de dados e a aplicação de requisitos legais a estas

\footnotetext{
${ }^{268}$ No período entre 12 de outubro de 2011 e 10 de fevereiro de 2012 era possível enviar comentários ou sugestões à proposta apresentada. Documento disponível em: <http://www.oecd.org/tax/taxtreaties/48836726.pdf $>$. Acesso em 10 de outubro de 2012.

269 
mensagens, analisando a admissibilidade e a força probante das mensagens de dados, visando a uniformizar a formação e validade dos contratos eletrônicos.

A segunda e última parte da norma trata de áreas específicas, disciplinando o contrato de transporte de mercadorias, que é considerado vital nas transações do comércio eletrônico indireto.

\subsubsection{Comércio Eletrônico no MERCOSUL}

As discussões relativas ao comércio eletrônico no âmbito do MERCOSUL, grupo econômico formado pela Argentina, Brasil, Paraguai e Uruguai, tiveram seu início formal com a expedição da Resolução do Grupo Mercado Comum GMC n 43/2000, que criou um grupo Ad Hoc com o objetivo de "coordenar as posições nacionais, fortalecendo o relacionamento externo do bloco nesta matéria e contribuir para o melhoramento do marco jurídico fiscal, de meios de pagamento e infraestrutura, necessários para o rápido desenvolvimento intrazona do comércio eletrônico". ${ }^{270}$

O Grupo Ad Hoc constituído foi transformado em um Subgrupo de Trabalho pela Decisão GMC no 59/00. Os subgrupos de trabalho são subordinados ao Grupo Mercado Comum (GMC) e têm a função de auxiliar o Grupo em suas atividades, por meio da discussão e elaboração de projetos de resoluções, cuja aprovação final fica a cargo do GMC.

O Subgrupo de Comércio Eletrônico - SGT 13 editou duas normas relativas ao assunto: a Resolução GMC no 22/04 e a Resolução GMC no 37/06. A Resolução $n^{\circ}$ 22/04 aprovou o uso de assinatura digital para a certificação das cópias dos documentos que deve realizar a Secretaria do MERCOSUL. ${ }^{271}$

Já a Resolução $n^{\circ}$ 37/06 reconhece a eficácia jurídica do documento eletrônico, da assinatura eletrônica e da assinatura eletrônica avançada ${ }^{272}$ no âmbito do MERCOSUL.

${ }^{270}$ Resolução GMC n 43/2000. Disponível em: 〈www.mercosul.gov.br/normativas/resolucao/2000〉. Acesso em 20 de novembro de 2012.

271 Resolução GMC n 22/2004. Disponível em: <http://www.mercosul.gov.br/normativa/resolucao/2004>. Acesso em 20 de novembro de 2012.

272 “Assinatura eletrônica avançada" é aquela que cumpre os seguintes requisitos: a) requerer informação de exclusivo conhecimento do signatário, permitindo sua identificação unívoca; b) ser criada por meios que o signatário possa manter sob seu exclusivo controle; c) ser suscetível de verificação por terceiros; d) estar vinculada a esses dados de tal modo que qualquer alteração subsequente nos mesmos seja 
Mas o tema do comércio eletrônico ganhou envergadura no bloco com a instituição do projeto MERCOSUL Digital em fevereiro de 2009, uma iniciativa de cooperação internacional entre a União Europeia, representada pela Comissão das Comunidades Europeias, e o MERCOSUL. O escopo do projeto é a redução das assimetrias legais e tecnológicas e a promoção de políticas e estratégias comuns na área da sociedade da informação, que contribuam para o crescimento e a integração econômica e fomente o desenvolvimento do comércio eletrônico na região. Além disto, o projeto tem ainda como objetivo buscar a harmonização dos regulamentos, a implementação da infraestrutura técnica e o intercâmbio de conhecimentos. ${ }^{273}$

Os focos do projeto MERCOSUL Digital são as áreas de comércio eletrônico, formação continuada, desenvolvimento das micros, pequenas e médias empresas (MPMEs) e os temas da sociedade da informação, a partir de duas vertentes: o comércio eletrônico e a educação continuada.

Sob a rubrica do comércio eletrônico no MERCOSUL está prevista uma série de ações voltadas a um marco regulatório das tecnologias digitais, que visam a consolidar a infraestrutura necessária para as transações eletrônicas. Neste sentido, o projeto tem por objetivo a "criação de um marco regulatório comum e infraestrutura tecnológica no MERCOSUL, para temas referentes à certificação digital, infraestrutura de chaves públicas, carimbo de tempo, proteção de dados para negociações transnacionais e desenvolvimento de uma plataforma comum para a venda de produtos e serviços voltados às micro, pequenas e médias empresas". ${ }^{274}$

O grupo MERCOSUL Digital apresentou, em um Congresso realizado em novembro de 2012 no Brasil, as metas, os desafios e os resultados obtidos pelo grupo relativamente ao comércio eletrônico. As ações do grupo são voltadas, fundamentalmente, a quatro vertentes: aspectos aduaneiros, impositivos, logística e marco regulatório. ${ }^{275}$

detectável; e e) haver sido criada utilizando um dispositivo de criação de assinatura tecnicamente seguro e confiável e estar baseada em um certificado reconhecido e válido no momento da assinatura. Resolução GMC n ${ }^{\circ}$ 37/06. Disponível em: <http://www.mercosul.gov.br/normativa/resolucao/2006/mercosur-gmcext-res-no-37-06/mercosur-gmc-ext-res-no-37-06/>. Acesso em 20 de novembro de 2012

273 Projeto Mercosul Digital. Disponível em: 〈http://www.mercosuldigital.org/projeto/>. Acesso em 20 de novembro de 2012.

${ }^{274}$ Mercosul Digital. Disponível em: 〈http://www.mercosuldigital.org/comercio-eletronico-2/>. Acesso em 20 de novembro de 2012.

275 Cf. ROLIM, Gerson; GONZALEZ, Leandro, Evolução do Comércio Eletrônico no MERCOSUL, In Emerging Markets Conference, Novembro 2012, ACERVO PROJETO MERCOSUL DIGITAL, São Paulo. 
Com a adoção de uma política e regulação adequadas, objetiva-se harmonizar as diferenças regulamentares regionais, garantindo a segurança jurídica necessária para garantir o mercado consumidor, com medidas como a incorporação da assinatura eletrônica e a definição do valor probatório dos documentos digitais.

Além disto, outro ponto importante é o impacto do comércio eletrônico na logística e transporte de produtos, que requer soluções para os problemas gerados pelas estruturas obsoletas, que não são capazes de proporcionar a qualidade de serviço necessária para o desenvolvimento do comércio eletrônico, já que há um aumento significativo do volume e das distâncias.

$\mathrm{Na}$ área fiscal, busca-se uma uniformidade na tributação entre os paísesmembros, visando a garantir o princípio da neutralidade e segurança para as partes envolvidas nas transações. Desta forma, o grupo estimula a participação de todos os Estados-membros na formulação de uma política fiscal adequada ao comércio eletrônico, para que as ações sejam coordenadas, minimizando tratamentos inconsistentes.

\subsection{0 conceito de "Estabelecimento Permanente" no Direito Internacional Tributário}

Conforme já constatamos, o nexo entre a atividade econômica e o território de um determinado país tem relevância nas atuais regras de tributação. Considerando-se que a configuração de um "estabelecimento permanente" em determinado território outorga ao país a competência para tributar determinadas operações, o conceito ganha relevância em especial para os países em desenvolvimento. O desafio que se impõe no comércio eletrônico é configurar algo como permanente a partir de um estabelecimento virtual. Neste sentido, questiona-se qual a diferença entre um equipamento que processe dados e esteja localizado no Brasil e um funcionário de uma empresa estrangeira que ingresse no país com um equipamento portátil para se conectar à matriz (em outro país), fazendo verificações, exames e downloads de dados e programas? Há estabelecimento permanente nos exemplos?

A Convenção Modelo da OCDE considera a presença concreta em determinado Estado como critério para a definição do local em que deve ser tributada 
determinada atividade, e estabelece em seu artigo $5^{\circ}$ as regras relativas à configuração do “estabelecimento permanente" para fins de tratados contra bitributação.

Trata-se de uma derrogação à regra geral, insculpida no art. $7^{\circ}$ do referido modelo, que define que o direito de tributar os lucros das empresas é objeto de atribuição exclusiva ao Estado em que tais empresas estão residentes, constituindo, ou significando, competência cumulativa para o Estado da fonte, quando neste se encontra instalado um estabelecimento permanente. ${ }^{276}$

O conceito de "estabelecimento permanente" surgiu no século XIX com a função de estabelecer a distinção entre o negócio fixo de uma empresa do negócio ambulante, que eram submetidos a regimes distintos de tributação: o negócio fixo enquadrava-se no regime de impostos gerais enquanto os negócios ambulantes eram submetidos a um imposto especial.

A definição de "estabelecimento permanente" adotada pelos modelos de convenções relaciona-se a todas as formas de atuação direta de pessoas não residentes em um território diverso daquele onde se localiza sua matriz. Heleno Torres utiliza a expressão para identificar "as formas de atuação cuja frequência, permanência ou estabilidade permita sua respectiva qualificação como um ente residente, exclusivamente para fins fiscais". 277

O artigo $5^{\circ}$ da Convenção Modelo da OCDE, além de definir "estabelecimento permanente", lista as instalações que devem assim ser nomeadas, excluindo ainda de seu âmbito alguns tipos de atividades temporárias, preparatórias ou auxiliares e as situações em que, necessariamente, não haverá um "estabelecimento permanente" (item 4). Vejamos:

Artigo 5. ${ }^{\circ}$ - Estabelecimento permanente.

1. Para efeitos da presente Convenção, a expressão "estabelecimento permanente" significa uma instalação fixa, por meio da qual a empresa exerça toda ou parte da sua atividade.

2. A expressão "estabelecimento permanente" compreende, nomeadamente:
a) Um local de direção;
b) Uma sucursal;
c) Um escritório;
d) Uma fábrica;

${ }^{276}$ Cf. XAVIER, Alberto, op. cit. (nota 08), p. 545.

277 TORRES, Heleno, Pluritributação Internacional sobre as Rendas de Empresas, $2^{\mathrm{a}}$ ed., São Paulo, Editora Revista dos Tribunais, 2001, p. 216. 
e) Uma oficina; ou

f) Uma mina, um poço de petróleo ou gás, uma pedreira ou qualquer local de extração de recursos naturais.

3. Um canteiro de obras ou de montagem de projetos constituirá um estabelecimento permanente somente se a sua duração exceder doze meses.

4. Não obstante as disposições anteriores deste artigo, a expressão "estabelecimento permanente" não compreende:

a) As instalações utilizadas unicamente para armazenar, expor ou entregar mercadorias pertencentes à empresa;

b) Um depósito de mercadorias pertencentes à empresa, mantido unicamente para armazenar, expor ou entregar;

c) Um depósito de mercadorias pertencentes à empresa, mantido unicamente para serem transformadas por outra empresa;

d) Uma instalação fixa, mantida unicamente para comprar mercadorias ou reunir informações para a empresa;

e) Uma instalação fixa, mantida unicamente para exercer, para a empresa, qualquer outra atividade de caráter preparatório ou auxiliar;

f) Uma instalação fixa, mantida unicamente para o exercício de qualquer combinação das atividades referidas nas alíneas a) a e), desde que a atividade de conjunto da instalação fixa desta combinação seja de caráter preparatório ou auxiliar.

5. Não obstante o disposto nos n. ${ }^{\circ}$ s 1 e 2 , quando uma pessoa - que não seja um agente independente, a quem é aplicável o $n .^{\circ} 6$ - atue por conta de uma empresa e tenha e habitualmente exerça num Estado contratante poderes para concluir contratos em nome da empresa do outro Estado contratante será considerado que esta empresa tem um estabelecimento permanente no primeiro Estado mencionado relativamente a qualquer atividade que essa pessoa exerça, a não ser que as atividades de tal pessoa se limitem às indicadas no n. ${ }^{\circ} 4$, as quais, se fossem exercidas por meio de uma instalação fixa, não permitiriam considerar esta instalação fixa como um estabelecimento estável, de acordo com as disposições desse número.

6. Não se considera que uma empresa tenha um "estabelecimento permanente" num Estado contratante pelo simples fato de exercer a sua atividade nesse Estado por intermédio de um corretor, de um comissáriogeral ou de qualquer outro agente independente, desde que essa pessoa atue no âmbito normal da sua atividade.

7. $\mathrm{O}$ fato de uma sociedade residente de um Estado contratante controlar ou ser controlada por uma sociedade residente do outro Estado contratante ou que exerça a sua atividade nesse outro Estado (quer seja por meio de um estabelecimento permanente, quer de outro modo) não é, por si só, bastante para fazer de qualquer dessas sociedades estabelecimento estável da outra. (g.n.) ${ }^{278}$

Trata-se de regra excepcional que autoriza os Estados a tributar os resultados das atividades desenvolvidas em seu território, desde que corporificadas numa

278 OCDE, Artigo $5^{\circ}$ da Convenção Modelo da OCDE, tradução livre. Disponível em: < http://www.oecd.org/dataoecd/14/32/41147804.pdf. >. Acesso em 12 de março de 2011. 
estrutura estável, numa base fixa. ${ }^{279}$ Tecnicamente, o critério do "estabelecimento permanente" permite uma análise qualitativa da tributação, isto é, possibilita obter respostas sobre quem é o contribuinte (quem paga) e qual Estado tem o direito subjetivo de tributar determinada atividade. Já o critério dos preços de transferência possui uma abordagem quantitativa, auxiliando, numa etapa posterior, na fixação do quantum a ser desembolsado àquele título. ${ }^{280}$

Desta forma, as diretrizes contidas no art. $5^{\circ}$ do Modelo OCDE atribuem a um Estado, e consequentemente retiram de outro, o direito subjetivo de tributar determinadas atividades, que estão relacionadas ao seu território pelo elemento de conexão do "estabelecimento permanente". Os elementos de conexão são elementos normativos que, determinando a "localização" de uma situação da vida num certo ordenamento tributário, têm como efeito típico determinar o âmbito de aplicação das leis desse ordenamento a essa situação. O assunto será retomado no item 5.13 do presente estudo.

É possível entrever no conceito de "estabelecimento permanente" uma função positiva e outra negativa. Esta se refere ao limite objetivo à competência do estado de residência sobre os rendimentos obtidos por seus residentes em outros estados por meio de um estabelecimento permanente. A função positiva revela-se na vinculação para efeitos tributários de uma pessoa jurídica não-residente a um Estado onde se localiza a instalação. $^{281}$

Os países em desenvolvimento tecem fortes críticas ao princípio do "estabelecimento permanente" por seu caráter restritivo, dando preferência a uma maior amplitude proporcionada pelo princípio da territorialidade, em especial em sua acepção princípio da fonte. Segundo Xavier, algumas convenções alargam a definição de "estabelecimento permanente" contida no Modelo OCDE, estendendo o conceito às exposições de mercadorias ou mesmo instalações de armazenagem, chegando até a admitir a tributação sem a existência de uma base física. ${ }^{282}$

Alberto Xavier define "estabelecimento permanente" como "a instalação fixa de negócios em que a empresa exerce toda ou parte de sua atividade". Os atributos da produtividade ou da rentabilidade não são requisitos essenciais do conceito, segundo Xavier, que entrevê as seguintes características no conceito: "a existência de uma

\footnotetext{
${ }^{279}$ Cf. XAVIER, Alberto, op. cit. (nota 08), p. 546.

${ }^{280}$ Cf. GAZZO, Massimiliano, op. cit. (nota 2), p. 257.

${ }^{281}$ Cf. TORRES, Heleno, op. cit. (nota 277), p. 217.

${ }^{282}$ Cf. XAVIER, Alberto, op. cit. (nota 08), p. 547.
} 
instalação material, com caráter de permanência, que faça parte da empresa, a qual deve exercer a sua atividade nesta instalação ou por meio desta instalação". ${ }^{283}$

Podemos, portanto, vislumbrar no conceito de "estabelecimento permanente" os seguintes elementos ou características: (i) uma instalação material, ou seja, um estabelecimento físico; (ii) um elemento temporal (caráter de permanência); (iii) as atividades da empresa devem se desenvolver nas mencionadas instalações e (iv) as atividades desenvolvidas nesta instalação devem coincidir com aquelas praticadas pela empresa a que se atribui um "estabelecimento permanente".

O conceito admite doutrinariamente duas tendências para sua definição: "a teoria da pertença" e "a teoria da realização"; esta exige para a configuração do "estabelecimento permanente" a obtenção ou realização de lucro, outorgando ao conceito um caráter produtivo, enquanto aquela entende como suficiente a inserção das instalações na economia do país, prescindindo de um caráter imediatamente produtivo. ${ }^{284}$

O Brasil adota em suas convenções a "teoria da pertença econômica", mitigando, contudo o conceito, introduzindo-lhe algumas das limitações da "teoria da realização".

As convenções internacionais costumam normalmente contemplar, além da definição de "estabelecimento permanente", uma lista de exemplos e exceções ao conceito; os exemplos são entendidos por alguns como uma presunção iuris et de jure daquela condição. Desta opinião não comunga Alberto Xavier, para quem ainda que sejam listadas determinadas situações tidas a priori como "estabelecimento prestador", é imprescindível a verificação da configuração dos requisitos contidos na noção geral.

As exceções ao conceito geral de "estabelecimento permanente" baseiam-se na "teoria da realização", que abranda a aplicação da "teoria da pertença econômica", excluindo da abrangência daquela noção (estabelecimento permanente) as situações em que não haja um caráter produtivo direto, como instalações para armazenagem, exposição de mercadorias, instalações físicas que se destinem exclusivamente à compra e venda, à reunião de informações para a empresa ou para fins de publicidade. São as denominadas atividades meramente auxiliares ou preparatórias, que 
segundo Alberto Xavier, "não têm caráter produtivo direto, não lhes sendo diretamente imputável a realização de lucros ou outros rendimentos". ${ }^{285}$

A convenção firmada pelo Brasil com a China, conforme observa Alberto Xavier ${ }^{286}$, seguiu neste sentido o Modelo da ONU, considerando tratar-se de "estabelecimento permanente" mesmo quando não há instalação física, trazendo ainda um caso específico previsto no art. $5^{\circ}, \S 3^{\circ}$, “b”, qual seja:

a prestação de serviços, inclusive de consultoria, por empresas de um Estado Contratante, por intermédio de funcionários ou de pessoal contratado no outro Estado Contratante, desde que tais atividades tenham sequência, em um mesmo projeto, ou outro projeto a ele relacionado, por um período ou períodos perfazendo mais de seis meses dentro de qualquer período de 12 meses. ${ }^{287}$

Os rendimentos provenientes das prestações de serviço são considerados, nas convenções assinadas pelo Brasil, como receitas brutas que integram o "lucro da empresa", sujeitando-se, portanto, em regra à tributação exclusiva no país de domicílio da empresa, nos termos do art. $7^{\circ}$ (tratando-se de empresa) ou do art. 14 (quando se trate de trabalho autônomo desenvolvido por pessoa física) do Modelo OCDE, cuja única exceção é a existência de um "estabelecimento permanente" no país da fonte deste rendimento.

O critério privilegia o princípio da territorialidade, de modo que, inexistindo estabelecimento, dentro daqueles parâmetros convencionais traçados, não haverá tributação, já que o lucro não pode ser imputado àquele determinado país.

Relativamente ao comércio eletrônico, outra questão polêmica quanto ao conceito de "estabelecimento permanente" é a possibilidade de um servidor de dados, um web site ou um agente da empresa configurar um "estabelecimento permanente"; de modo geral, a solução impõe que se verifique se estão presentes nestas situações os requisitos configuradores contidos no conceito, que passaremos a analisar. ${ }^{288}$

${ }^{285}$ XAVIER, Alberto, op. cit. (nota 08), p. 551.

${ }^{286}$ Cf. Idem, ibidem, p. 550.

287 Convenção Brasil China. Disponível em: 〈http://www.receita.fazenda.gov.br/Legislacao/AcordosInternacionais/China/Dec7621993.htm>. Acesso em 5 de julho de 2011.

${ }^{288}$ Cf. PINTO, Dale, E-Commerce and Source-based Income Taxation, Amsterdam, IBFD, Doctoral Series, v.6, 2003, p. 38. 


\subsubsection{O “Estabelecimento Permanente Físico" - Servidor de Dados}

Há dois conceitos de "estabelecimento permanente" relevantes para o comércio eletrônico: o "estabelecimento permanente físico", enquanto instalação material onde os negócios são conduzidos, e o estabelecimento permanente na figura de um agente da empresa. O conceito de "estabelecimento permanente físico" exige a vinculação do lugar dos negócios a um ponto geográfico específico em determinado território. Os comentários ao parágrafo $1^{\circ}$ do artigo $5^{\circ}$ da $\mathrm{CM}$ da OCDE advertem que para a configuração de um "estabelecimento permanente" enquanto lugar de negócios é prescindível a existência de um bem imóvel, sendo possível que se configure o conceito a partir de bens móveis, como máquinas, instalações e equipamentos que componham o local onde se desenvolvem os negócios, e estejam à disposição da empresa para serem utilizados no desenvolvimento de suas atividades empresariais.

Portanto, o estabelecimento permanente material equivale a "um centro de referência para imputação de situações jurídicas, atribuíveis, em última análise, à sede principal, materializado na organização de elementos materiais e pessoais predispostos para o exercício da atividade produtiva de rendimentos". 289

Os web sites, que são programas de computador que residem em um servidor, são hoje uma forma popular de realizar negócios na Internet. As homepages das empresas podem estar hospedadas em um servidor de propriedade da própria empresa, ou, alternativamente, localizadas em um servidor mantido por fornecedores de serviço de Internet, os ISPs. A localização do servidor de dados é uma questão de conveniência, podendo ser definida em função de razões comerciais, como custos de acesso e largura de banda, não guardando qualquer relação com "fonte" de produção ou localização do consumo no comércio eletrônico. ${ }^{290}$

Outra questão que surge no contexto da necessidade da utilização de certa quantidade de espaço à disposição da empresa é o "espaço de armazenamento em disco" no regime de web hosting, quando uma empresa exerce sua atividade usando o servidor em que está hospedado, mantido por um ISP. Neste caso, como há certo "espaço" de armazenagem disponibilizado à empresa, poder-se-ia argumentar que um site constituiria um local de atividade. No entanto, os contratos de hospedagem na web não

${ }^{289}$ Cf. TORRES, Heleno, op. cit. (nota 277), p. 224.

${ }^{290}$ Cf. PINTO, Dale, op. cit. (nota 288), p. 41. 
arrendam espaço em disco ou em servidores, ainda que a remuneração seja feita desta forma. $^{291}$

Importante ressaltar que, caso a empresa possua ou arrende o servidor de dados que utiliza para armazenar seu site, o local onde estiver instalado o equipamento pode ser considerado um "estabelecimento permanente", caso sejam satisfeitos concomitantemente os outros requisitos do art. $5^{\circ}$.

Segundo Skaar ${ }^{292}$, é necessário que se diferencie equipamento e maquinário portátil do não portátil, já que somente este poderia configurar um “estabelecimento permanente". Entretanto, há determinados tipos de atividades que exigem deslocamentos constantes e, segundo esta teoria, tais atividades que possuem natureza itinerante, como circos ou espetáculos artísticos, não constituiriam estabelecimentos permanentes.

Outra distinção importante a ser feita em relação ao tema é entre os ativos tangíveis e intangíveis. Um local de atividade abrange somente os ativos tangíveis necessários para a atividade empresarial. Direitos de crédito, valores mobiliários ou direito de propriedade imaterial, como os softwares, não podem ser considerados como “estabelecimento permanente". 293

Desta forma, fica descartada a configuração de um web site como estabelecimento permanente enquanto local de negócios, já que se trata de uma mera combinação de software e dados eletrônicos.

Para que um lugar de negócios possa ser considerado como estabelecimento permanente determina o parágrafo $4^{\circ}$ dos comentários ao artigo $5^{\circ}$ da Convenção Modelo da OCDE que o local deva ser utilizado pelo próprio não residente e que esteja à disposição da empresa, requisito denominado como "teste do direito de uso" (right of use test). Na Alemanha, exige-se um liame legal entre o não residente e o local onde exerce suas atividades, não considerando o mero uso real do lugar como condição suficiente para a configuração de um "estabelecimento permanente". A jurisprudência daquele país tem refutado a mera utilização de determinadas instalações para a configuração do conceito; assim, portanto, caso um consultor desenvolva suas atividades

\footnotetext{
${ }^{291}$ Cf. PINTO, Dale, op. cit. (nota 288), p. 49.

${ }^{292}$ Cf. SKAAR, Arvid Aaage, Erosion of the Concept of Permanent Establishment, Electronic Commerce, Nova Delhi, IFA Congress, 1997, Apud VASCONCELOS, Roberto de França, op. cit. (nota 113), p. 183.

${ }^{293}$ Cf. PINTO, Dale, op. cit. (nota 288), p. 46.
} 
nas instalações do próprio cliente, sem que haja qualquer prerrogativa legal ou contratual neste sentido, não se pode falar em estabelecimento permanente. ${ }^{294}$

Nos países anglo-saxônicos, ao contrário, não se exige qualquer prerrogativa legal sobre o local onde se desenvolvem os negócios, sendo que o mero uso efetivo de determinadas instalações é suficiente para que se considere que o lugar estava à disposição para utilização. ${ }^{295}$ No mesmo sentido, caminha a recente jurisprudência do Superior Tribunal de Justiça na definição do estabelecimento prestador para fins de incidência do ISS, conforme acórdão proferido no Recurso Especial n 1.195 .844 , que será analisado no item 5.17 .

\subsubsection{A Permanência da Instalação: Elemento Temporal e Espacial}

O conceito de permanência está associado à ideia de algo estável, duradouro, de caráter definitivo. Destarte, atribuir ao estabelecimento o predicado de "permanente" significa entendê-lo como fixo em determinado local por certo lapso de tempo; vale dizer que o conceito contempla, além de um elemento espacial, também um elemento temporal. As convenções internacionais não definem os termos "estabilidade" ou "permanência" relativos ao estabelecimento. ${ }^{296}$

A vinculação da atividade a uma localização geográfica específica não deve ser temporária, não havendo, no entanto, a exigência de tempo predeterminado para que possa ser atendido o requisito da permanência. Estariam afastados, desta forma, os negócios constituídos com caráter temporário do conceito de "estabelecimento permanente". Por outro lado, mesmo que tenha o negócio sido concebido como temporário, caso sua existência se protraia no tempo, estará atendido o requisito da permanência.

Portanto, para que se configure um "estabelecimento permanente", o uso efetivo de determinado lugar de negócios deve ser estabelecido em termos temporais. A permanência não significa que o direito de usar determinado local de trabalho deva ser

\footnotetext{
${ }^{294}$ Cf. VASCONCELOS, Roberto de França, op. cit. (nota 113), p. 190.

${ }^{295}$ Cf. Idem, ibidem, p. 190.

${ }^{296}$ Cf. TORRES, Heleno, op. cit. (nota 277), p. 225.
} 
perpétuo. O período de seis meses parece satisfazer os requisitos temporais da definição por muitos países, para que se configure a permanência. ${ }^{297}$

No Brasil, os não-residentes sujeitam-se à tributação do Imposto sobre a Renda como residentes quando permanecem no país por um período superior a cento e oitenta e três dias, consecutivos ou não. ${ }^{298}$ Este limite temporal pode ser utilizado como parâmetro à configuração do requisito da permanência de um estabelecimento.

No comércio eletrônico, a instalação de um servidor em um escritório deverá satisfazer os requisitos do chamado "teste geográfico", que exige a vinculação da empresa a um ponto geográfico específico, comprovado pela existência de contas de consumo, ou extratos bancários relativos ao local físico. ${ }^{299}$

$\mathrm{O}$ fato dos servidores de dados serem móveis pode afetar sua configuração como um estabelecimento permanente; os comentários à CM-OCDE enfatizam que fundamental não é o fato de que ele possa ser movido, mas sim se ele foi de fato movido, o que sugere uma análise casuística, que pode gerar incerteza. Em função disto, países como o Reino Unido e a Suíça assumiram posições de que nem um web site, nem um servidor devem constituir um "estabelecimento permanente". 300

O prazo que determinado web site está vinculado a um provedor pode ser decisivo para configurar ou não um "estabelecimento permanente", seja por força de um contrato, ou do tempo de permanência efetiva do site no Servidor. Da mesma forma, um servidor não precisa estar indefinidamente vinculado a um local para que haja algum grau de permanência; nos termos do parágrafo 42.2 dos comentários ao art. $5^{\circ}$ da OCDE, além do outros requisitos, o servidor deve estar localizado em determinado local por um período de tempo suficiente para se tornar fixo na acepção do conceito.

\subsubsection{O Teste da Atividade Econômica (Business Activity Test)}

Para a caracterização de um "estabelecimento permanente", entre outros requisitos, exige-se a identidade entre a natureza das atividades desenvolvidas no local da

\footnotetext{
${ }^{297}$ Cf. PINTO, Dale, op. cit. (nota 288), p. 51.

${ }^{298}$ Art. 12 da Lei n ${ }^{\circ} 9.718$ de 27 de novembro de 1998; Instrução Normativa SRF n ${ }^{\circ} 208$, de 27 de setembro de 2002 , art. $2^{\circ}$, com a alteração dada pela Instrução Normativa RFB $n^{\circ} 1.008$, de 9 de fevereiro de 2010.

${ }^{299}$ Cf. PINTO, Dale, op. cit. (nota 288), p. 50.

${ }^{300}$ Cf. Idem, ibidem, p. 50.
} 
sede ou da residência da empresa e aquelas desempenhadas no outro país em que se pretende configurar um "estabelecimento permanente". A exigência explica-se porque, para que haja a tributação no país onde está localizado o "estabelecimento permanente", a renda ali produzida deve qualificar-se como lucro da empresa, conforme previsto no art. $7^{\circ}$ da Convenção Modelo.

Desta forma, somente haverá estabelecimento permanente quando este fizer parte do ciclo produtivo da empresa, colaborando efetivamente no desenvolvimento da atividade produtiva desempenhada pela matriz. ${ }^{301}$

A primeira questão que se impõe em relação ao comércio eletrônico é a possibilidade de equiparação entre as atividades desenvolvidas por meio de um site e aquelas praticadas ordinariamente pela empresa.

O artigo $5^{\circ}$ da Convenção Modelo exclui do conceito de "estabelecimento permanente" as instalações utilizadas unicamente para armazenagem, exposição ou expedição de mercadorias, que não possuem caráter produtivo direto, isto é, não são diretamente relacionadas com a realização de lucros ou outros rendimentos.

No comércio eletrônico, também é necessário definir precisamente o papel que exerce o servidor de dados: se tem mero propósito de armazenamento, exibição ou propaganda, ou seja, se realiza aquelas ditas "atividades meramente auxiliares ou preparatórias", ou se desempenha todas as atividades ditas "produtivas", desenvolvidas ordinariamente em estabelecimentos comerciais físicos, que abrangem todo o ciclo aquisitivo. No caso de as atividades do servidor de dados revelarem-se meramente preparatórias ou auxiliares, segundo os requisitos da Convenção Modelo, não será reconhecida a existência de um estabelecimento permanente; por outro lado, no caso de um servidor ativo, capaz de receber e processar pedidos, pagamentos e agendar entregas, ainda que sem presença humana, deverá ele ser considerado como um estabelecimento permanente.

Neste sentido, antes mesmo do advento do comércio eletrônico, a Convenção Modelo da OCDE já considerava as máquinas de jogos (gaming machines) e máquinas de venda como "estabelecimentos permanentes".

Entretanto, é importante estabelecer uma distinção entre as máquinas de venda e de jogos, objeto dos comentários da OCDE, e os servidores de dados utilizados no 
comércio eletrônico; no caso das máquinas de jogos e venda, sua localização é crítica para o negócio, posto que sua clientela é aquela da jurisdição onde estiverem instaladas, de modo que se tais equipamentos forem constantemente movidos a base de clientes seria perdida ou alterada. No caso do servidor, sua localização é irrelevante para o consumidor do comércio eletrônico. Portanto, as máquinas de jogos e vendas geram uma "presença econômica" com a sua existência física no local, enquanto a instalação de um servidor em um país não representa necessariamente a presença econômica da empresa.

Outra distinção entre o servidor de dados e as máquinas é que nestas toda a transação é conduzida por meio de uma interação do usuário com a máquina, ao passo que as atividades do servidor de dados são "geralmente muito limitadas", sendo este visto apenas como um meio de comunicação ou instrumento de entrega. Mesmo no caso da aquisição de produtos digitais, como música e software, ainda que o servidor seja capaz de aceitar o pedido, efetuar a cobrança e entregar o produto, não poderia ser considerado mais do que um instrumento de entrega. ${ }^{302}$

A mera adaptação conceitual de "estabelecimento permanente" à existência de um servidor de dados ou de conteúdo em determinado território preserva a noção de localizar um bem físico em função de determinada posição geográfica. Tal interpretação poderá levar os agentes econômicos a deslocar a hospedagem de seus servidores de conteúdo para paraísos fiscais, evitando, desta forma, a tributação dos rendimentos auferidos nestas operações.

A tentativa de preservar a tributação nos países da origem atribuindo o nexo para a imposição tributária em função da localização de infraestrutura como servidores de dados é uma base insatisfatória e instável. Em 1996, o Departamento do Tesouro dos Estados Unidos, em um relatório sobre as implicações fiscais no comércio eletrônico, já alertava que "os servidores de computador podem estar localizados em qualquer lugar do mundo e seus usuários são indiferentes à sua localização. É possível que um servidor ou equipamento semelhante não seja elemento suficientemente significativo na geração de certos tipos de rendimentos". 303

Ainda que a localização do servidor seja relevante para a tributação, a possibilidade de movimentação do equipamento e da criação de "servidores espelho" que replicam todo o conteúdo de outro servidor, possibilitando que as operações sejam

${ }^{302}$ Cf. PINTO, Dale, op. cit. (nota 288), p. 51.

${ }^{303}$ EUA, The Department of Treasury, op. cit. (nota 227). Acesso em 26 de novembro de 2012. 
distribuídas ou direcionadas, podem dificultar a definição de uma presença estável física sobre a qual possa ser baseada a tributação.

A adaptação do conceito de "estabelecimento permanente" sob o enfoque da atividade econômica deve incorporar meios virtuais de representação do fornecedor, como, por exemplo, seu web site, por meio do qual disponibiliza e transaciona seus produtos e serviços com os consumidores de determinado país. ${ }^{304}$ No entanto, a concepção de um conceito de "estabelecimento permanente virtual", baseado unicamente na presença de uma página eletrônica da empresa, poderia levar ao fenômeno da pluritributação, já que atuando em bases globais, poderia estar sujeito à tributação de impostos em uma multiplicidade de países. ${ }^{305}$

Portanto, qualquer alteração ou adaptação conceitual exigirá que um entendimento predominante seja acatado pela comunidade internacional, para que se evitem os dois fenômenos indesejados por todos os países: a pluritributação ou a ausência de tributação sobre as operações do comércio eletrônico.

\subsubsection{O Agente como Estabelecimento Permanente}

A Convenção Modelo da OCDE reconhece o caráter de "estabelecimento permanente" a um "agente", assim considerada aquela pessoa autorizada que atue e contrate em nome da empresa, sem que haja um local fixo de negócios.

A capacidade e autorização para a celebração de contratos em nome da empresa, cujo objeto, necessariamente, esteja relacionado às atividades principais da empresa, são requisitos essenciais para tal caracterização. Ressalte-se que, para que haja a configuração de um "estabelecimento permanente", o agente deve ser responsável pela conclusão do contrato e não somente solicitar autorização ou negociá-lo.

O aspecto de "permanência" inerente ao estabelecimento permanente é representado em relação ao agente pela exigência de que tal atividade seja exercida com habitualidade.

${ }^{304}$ Cf. SILVA, Emerson, Aspecto Espacial da Incidência do ISS Sobre os Serviços Prestados via Internet, in Internet - O Direito na Era Virtual. SCHOUERI, Luis Eduardo, organizador, 2a . ed., Rio de Janeiro, Forense, 2001, p. 64.

${ }^{305}$ Cf. Idem, ibidem, p. 65. 
Aplicando-se tais definições a um web site e um servidor de dados, que por óbvio não são pessoas, pode-se de plano afastar a ideia de que eles possam ser considerados como agentes de uma empresa. Outra questão que deve ser considerada neste contexto é se o provedor ISP poderia ser considerado agente de uma empresa da qual hospeda um site, já que fornece os meios informáticos necessários para que as vendas online sejam realizadas. Além disto, as transações são possibilitadas e os contratos são celebrados por meio de softwares fornecidos pelo ISP e localizado em seu servidor. ${ }^{306}$

No entanto, o prestador do serviço não representa o proprietário do site em relação aos clientes do web site, mas de muitos outros que hospedam ali suas páginas, de forma que o servidor somente poderia ser considerado como agente independente em relação a seus próprios negócios.

Uma nova problemática que surge em relação ao comércio eletrônico é o denominado "agente de software" que executa funções "inteligentes"; trata-se do programa utilizado para as vendas do comércio eletrônico direto que é capaz de realizar toda a transação, fornecer a descrição completa do produto e ainda efetuar a "entrega" do produto por meio da liberação do download. Neste compasso, questiona-se se os agentes de software, que realizam essencialmente as funções de agentes humanos, podem ser a estes equiparados e, assim, configurar "estabelecimentos permanentes". 307

No Brasil, o Regulamento do Imposto sobre a Renda, Decreto n 3000 de 26 de março de 1999, trata da tributação dos agentes em seus artigos 398 e $399 .{ }^{308}$ O caput

${ }^{306}$ Cf. PINTO, Dale, op. cit. (nota 288), p. 59.

${ }^{307}$ Cf. Idem, ibidem, p. 59.

${ }^{308}$ Decreto no 3000/99 - Art. 398. As normas deste Decreto sobre determinação e tributação dos lucros apurados no Brasil pelas filiais, sucursais, agências ou representações das sociedades estrangeiras autorizadas a funcionar no País alcançam, igualmente, os rendimentos auferidos por comitentes domiciliados no exterior, nas operações realizadas por seus mandatários ou comissários no Brasil (Lei $\mathrm{n}^{\circ}$ 3.470, de 1958, art. 76).

Parágrafo único. O disposto neste artigo aplica-se aos rendimentos auferidos por comitentes residentes ou domiciliados no exterior em virtude de remessa para o Brasil de mercadorias consignadas a comissários, mandatários, agentes ou representantes, para que estes as vendam no País por ordem e conta dos comitentes, obedecidas as seguintes regras:

I - o intermediário no País que for o importador ou consignatário da mercadoria deverá escriturar e apurar o lucro da sua atividade separadamente do lucro do comitente residente ou domiciliado no exterior (Lei $\mathrm{n}^{\circ}$ 3.470 , de 1958 , art. $76, \S 1^{\circ}$ );

II - o lucro operacional do intermediário será a diferença entre a remuneração recebida pelos seus serviços e os gastos e despesas da operação que correrem por sua conta;

III - o lucro operacional do comitente será a diferença entre o preço de venda no Brasil e o valor pelo qual a mercadoria tiver sido importada acrescido das despesas da operação que correrem por sua conta, inclusive a remuneração dos serviços referidos no inciso anterior;

IV - na falta de apuração, nos termos dos incisos anteriores, os lucros do intermediário e do comitente serão arbitrados na forma do disposto neste Decreto; 
do artigo 398 impõe a tributação do não residente que estiver atuando no Brasil por meio de um agente. A tributação, por meio de agentes não residentes atuando no país, ocorre em duas possibilidades: (i) quando são enviados bens ao Brasil sob um contrato de consignação e vendidos internamente por agentes locais, em nome e em benefício de um não residente; e (ii) sobre as vendas efetuadas por um não-residente, e que sejam cobradas diretamente do consumidor brasileiro, quando estas vendas tenham sido concluídas por meio de um agente ou representante local.

Vale dizer, o legislador brasileiro ao instituir os critérios da incidência do imposto sobre a renda não se fixou na existência de uma estrutura fixa, representada em um "estabelecimento permanente", que se tornou um elemento incidental, atendo-se ao negócio que é gerado aqui, cujo rendimento será tributado. ${ }^{309}$

\subsection{Propostas para a Tributação do Comércio Eletrônico}

Alberto Xavier há muito alertava que os pressupostos que conformam o princípio da territorialidade, representados pelos aspectos materiais das situações tributáveis, como o local da situação dos bens, local do exercício de uma atividade ou o local do estabelecimento permanente, têm passado por uma "sucessiva desmaterialização", motivo pelo qual deveria ser superada a visão clássica do referido princípio. ${ }^{310}$

$\mathrm{Na}$ mesma linha, Avi-Yonah entende que solucionar o problema da tributação do "comércio eletrônico" significa, entre outras medidas, alterar aqueles padrões vigentes para a definição da fonte que tributa a renda aplicando o conceito de “estabelecimento permanente", que se baseia na presença física no Estado em que ocorrerá a tributação. ${ }^{311} \mathrm{Ou}$ seja, em tempos de estabelecimento virtual, o conceito de "estabelecimento permanente" como critério de fixação da sujeição ativa pode se mostrar anacrônico em determinadas atividades. A proposta do autor é privilegiar o Estado de consumo, admitindo-se a tributação onde houver um mínimo de renda.

V - o intermediário no País cumprirá os deveres previstos para as filiais de empresas estrangeiras autorizadas a funcionar no País e será responsável pelo imposto devido sobre o lucro auferido pelo seu comitente.

Art. 399. No caso de serem efetuadas vendas, no País, por intermédio de agentes ou representantes de pessoas estabelecidas no exterior, o rendimento tributável será arbitrado de acordo com o disposto no art. 539 (Lei no $\underline{3.470}$, de 1958, art. $\underline{76}, \underline{\S 3^{\circ}}$ ).

${ }^{309}$ Cf. SCHOUERI, Luis Eduardo, op.cit. (nota 115), p. 52.

${ }^{310}$ Cf. XAVIER, Alberto, op. cit. (nota 08), p. 24.

${ }^{311}$ Cf. SCHOUERI, Luis Eduardo, op. cit. (nota 07), p. 53. 
Desta forma, os países em desenvolvimento poderiam alterar o sentido da tributação na fonte, permitindo-se a evolução do conceito de "fonte de produção" para “fonte de pagamento", representada pelo local onde está o consumidor.

Em 2001, Schoueri, em estudo sobre a tributação da renda do "comércio eletrônico", demonstrava preocupação com a definição de quem detém a capacidade ativa para tributar os rendimentos oriundos do comércio eletrônico, que é relevante para que se evite tanto a pluritributação como a não tributação de tais rendimentos. Neste diapasão, já postulava soluções similares àquelas propostas por Chang Hee Lee, relativas à validade da aplicação da neutralidade tributária e da prevalência da tributação no Estado onde ocorrer o pagamento. ${ }^{312}$

Em um ambiente virtual, que não se qualifica como nacional ou internacional, todos atuam em igualdade de condições, sejam residentes no país ou não, não havendo como precisar, com certeza, a proveniência dos produtos oferecidos, o que poderia afetar o comando constitucional relativo à igualdade, já que deveria ser oferecido o mesmo tratamento a residentes e não-residentes, desde que atuem no mercado em igualdade de condições. Nossa legislação concede o mesmo tratamento tributário àqueles que auferem lucro atuando no país, considerando como elemento de conexão para reputar a renda realizada no Brasil a existência de uma pessoa (estabelecimento, comissário ou representante), localizada fisicamente no país. ${ }^{313}$

$\mathrm{Na}$ busca de um critério que contemple os negócios do "comércio eletrônico", diante da dificuldade na utilização do critério da residência como elemento de conexão, propôs Schoueri a adoção daquele que considera "o lugar da constituição da obrigação". O critério atingiria todos os negócios jurídicos cujas obrigações sejam aqui constituídas, nos termos do disposto pela Lei de Introdução ao Código Civil, em seu artigo $9^{\circ}$, parágrafo $2^{\text {o: }}$ "a obrigação resultante do contrato reputa-se constituída no lugar em que residir o proponente". Considerando que a exposição em determinado site não constitui uma proposta, mas mera invitatio ad offerendum, concluiu Schoueri que o proponente é aquele que acessa o site, pouco importando onde este se hospeda. Neste sentido, convergem os critérios da fonte de produção e fonte de pagamento, na medida em que o contrato se considera celebrado no local em que se produz o rendimento. ${ }^{314}$

${ }^{312}$ Cf. SCHOUERI, Luis Eduardo, op. cit. (nota 07), p. 53.

${ }^{313} \mathrm{Cf}$. Idem, op. cit. (nota 115), pp. 52-53.

${ }^{314}$ Cf. Idem, ibidem, pp. 53-54. 
Destarte, a tributação do rendimento de operações de comércio digital deveria ocorrer no país em que reside aquele que acessa o site para adquirir mercadorias ou serviços; desta forma, o critério da presença física do vendedor (extensível ao prestador de serviço no conceito de "estabelecimento prestador") deveria ser deixado de lado na definição da tributação das atividades aqui desenvolvidas, devendo-se adotar como critério a residência do proponente, fixando-se a base de cálculo por critérios de arbitramento. ${ }^{315}$

Analisando a questão sob o prisma do sacrifício interestatal, o autor sustenta a tributação no lugar da fonte vista como o local onde está a fonte de pagamento, justificando a pretensão tributária do Estado em função de sua economia ser atingida pelas remessas de valores feitas ao exterior. Este sistema mostra-se viável na medida em que se cotejam as possibilidades de tributação nesta situação:

de um lado, um Estado instituindo um imposto sobre ativos no exterior (de que ainda não se cogita, mas que seria viável, do ponto de vista econômico, ainda que indesejável por desincentivar as transações internacionais), e, de outro, um imposto sobre os rendimentos pagos ao exterior (tributação na fonte). Note-se que, aqui, já não se cogita mais em justificar o montante do imposto na capacidade contributiva manifestada, ou nos benefícios oferecidos pelo Estado, mas exclusivamente na circunstância de o Estado ter sua economia nacional diminuída dos recursos enviados ao exterior. O "sacrifício" surge, pois sob nova forma. Agora já não se trata da circunstância de um rendimento haver sido produzido sob o manto protetor de um Estado (enfoque do benefício), mas de ele ser pago com recursos provenientes do Estado (enfoque do pagamento). ${ }^{316}$

No mesmo sentido, Greco também propôs o abandono do critério da residência no comércio eletrônico, entendendo que "o referencial físico (fixo) não é mais indispensável para o exercício de uma atividade econômica”. E prossegue arguindo a necessidade de se reavaliar a aplicação do critério da residência em função da mobilidade dos agentes, das atividades e da renda neste mercado eletrônico. E conclui:

quando o mundo vai a passos largos na direção do comércio de bens virtuais e do comércio através de meios eletrônicos, um dos poucos elementos captáveis será a movimentação financeira daí decorrente (oriunda do consumidor, fonte de pagamento na relação de comércio eletrônico) pois, de algum modo e em algum momento, os serviços, transações financeiras, acesso e obtenção de intangíveis etc. serão remunerados. ${ }^{317}$

${ }^{315}$ Cf. SCHOUERI, Luis Eduardo, op. cit. (nota 115), p. 54.

${ }^{316}$ Idem, ibidem, p. 50.

${ }^{317}$ GRECO, Marco Aurélio, op. cit. (nota 86), pp. 191 e 192. 
A simplicidade na determinação da fonte de pagamento é outro argumento favorável a este sistema de tributação, já que a questão passa a ser "quem pagou" e não onde se produziu a renda ou onde se prestou o serviço. Além disto, ainda que também possa haver dificuldades de se localizar a fonte pagadora no comércio eletrônico, esta se apresenta atomizada, ao contrário das empresas, "sendo mais difícil conceber que uma multiplicidade de consumidores crie estruturas sofisticadíssimas para o pagamento de suas compras eletrônicas". 318 Vale dizer, ainda que o número de consumidores seja exponencialmente maior do que o de empresas, o risco da utilização de esquemas ou estruturas para a prática de evasão fiscal cai na mesma proporção.

Alguns países já instituem impostos de renda sobre determinados tipos de rendimentos, como os royalties, produzidos em seus territórios, sem considerar se o beneficiário estabeleceu ali qualquer tipo de presença tributável. $\mathrm{O}$ gravame incide na fonte, devendo ser retido pelo pagador que tenha residência naquele país. É o caso do Brasil, por exemplo, que exige que o imposto sobre a renda seja retido na fonte sobre os pagamentos feitos por um residente em seu território para residente no exterior, independentemente da atividade produtiva ter ocorrido em seu território, ou de existência de um "estabelecimento permanente".

Roberto França de Vasconcellos, em estudo sobre a tributação internacional do comércio eletrônico, também elegeu o critério da fonte de pagamento como o elemento de conexão mais adequado para a definição do Estado que deterá a competência para tributar os rendimentos oriundos destas operações. Segundo o autor, os países em desenvolvimento, e importadores como o Brasil, diante do fenômeno do comércio eletrônico e da consequente volatilização dos "estabelecimentos permanentes" em seus territórios, tenderão a expandir os conceitos de presença tributável em seu território, ou ainda alterar as regras de classificação dos rendimentos, tudo visando a justificar a sua tributação. Relembra neste passo o autor que o Brasil e a Indonésia já se utilizam da "localização da fonte pagadora" em seus territórios como critério para estabelecer a tributação do não-residente. ${ }^{319}$

Segundo o autor, no comércio eletrônico o consumidor poderá ser equiparado pelos Estados à fonte de pagamento, deslocando, desta forma, a tributação para

${ }^{318}$ SCHOUERI, Luis Eduardo, op. cit. (nota 07), p. 51.

${ }^{319}$ Cf. VASCONCELLOS, Roberto de França, op. cit. (nota 113), pp. 137 a 144. 
seu país de residência, incidindo a tributação na fonte das remessas que estes residentes em seu território fizerem ao exterior a título de pagamento pela aquisição de bens e serviços. Alerta Vasconcellos que a proposição de que o único lugar com alguma importância no mundo digital é o lugar onde a pessoa vive ou reside pode também conduzir à tributação na residência do consumidor, o que beneficiaria os países da fonte pagadora.

No entanto, concluiu que os negócios virtuais ainda não eram suficientemente relevantes para ensejar um sistema de tributação diferenciado, já que à época o comércio de bens tangíveis ainda os superava. Para o autor, alguns ajustes seriam suficientes para que as atuais regras de tributação na fonte se adequassem ao "comércio eletrônico". ${ }^{320}$

Os estudos de Emerson Drigo consideraram a utilização de meios telemáticos para a conclusão dos contratos, apresentando como elemento de conexão possível nas transações do comércio eletrônico o local da constituição da obrigação, denominando-a como "teoria da oferta". ${ }^{321}$

Os contratos telemáticos, que são os instrumentos que operacionalizam a oferta e aceitação do negócio jurídico, caracterizam-se por não haver uma manifestação oral nem escrita da vontade das partes, substituída por um registro em meio virtual. Considerando, como Schoueri, a regra disposta no art. $9^{\circ}$ e $\S 2^{\circ}$ da Lei de Introdução ao Código Civil - LICC, concluiu também que o contrato reputa-se constituído no lugar em que residir o proponente. Nas transações em análise, tanto o prestador de serviços como o tomador podem ser considerados como proponentes do contrato de serviços, considerandose em ambos os casos o local da residência como aquele da constituição da obrigação.

A proposta de Drigo consiste em apontar como autoridade fiscal com jurisdição para tributar os serviços aquela em que for constituída a obrigação, concluindo que a análise concreta deve ser feita em cada caso. De modo geral, considerar-se-ia o prestador como proponente quando o negócio for avençado por meio de um contrato denominado clickwrap, um contrato de adesão eletrônico cuja aceitação é expressa apenas com o clique de um mouse. Já nos contratos em que tomador dos serviços intervir, definindo os termos da proposta, considera-se este o proponente da obrigação.

Ressalte-se que Schoueri, analisando qual das partes de um contrato eletrônico deve ser definido como proponente e considerando que a presença física não se 
presta mais como critério limitador da hipótese de incidência tributária, concluiu pelo tomador do serviço que acessa o site, considerando o local da residência do proponente como mais hábil a constituir o critério espacial da norma de competência. Note-se que neste contexto convergem os critérios do local onde o contrato se reputa celebrado (fonte de produção) e o local da produção de rendimento (fonte de pagamento). ${ }^{322}$

Doernberg, já em 1998, teceu uma proposta que consistia na retenção de um percentual sobre os pagamentos efetuados na fonte (países consumidores ou importadores), que incidiria sobre quaisquer valores enviados por consumidores daqueles países, independentemente da categoria da renda. ${ }^{323}$

Esta tributação alcançaria somente as operações denominadas businessto-business, isto é, as transações entre fornecedores e comerciantes residentes em outros países com uma alíquota de $10 \%$ sobre todos os pagamentos do residente ao beneficiário não-residente, sem qualquer consideração sobre a qualificação da renda. Ou seja, independentemente de tratar-se de royalty, juros ou lucro, o valor pago é tributado à taxa de $10 \%$, valor que seria reconhecido como crédito no país da residência. No sistema proposto, somente as pessoas jurídicas seriam tributadas, já que além da impopularidade e da dificuldade de fiscalizar a obrigação de retenção do imposto na fonte sobre todas as transações efetuadas por pessoas físicas em transações na Internet, a maioria das transações neste ambiente ocorre entre empresas (business-to-business).

De modo geral, a tendência das propostas apresentadas para a tributação do comércio eletrônico é a de justificar a tributação, exclusiva ou ao menos preferencialmente, nos países da fonte pagadora dos rendimentos, onde se localizam os consumidores das mercadorias e serviços adquiridos pelos canais eletrônicos.

${ }^{322}$ Cf. SCHOUERI, Luis Eduardo, op. cit. (nota 115), pp. 54-55.
${ }^{323}$ Cf. DOERNBERG, Richard L., op. cit. (nota 88), p. 16. 


\section{COMPETÊNCIA TRIBUTÁRIA: OS MUNICÍPIOS NA FEDERAÇÃO BRASILEIRA}

A Constituição Brasileira inaugura-se com a declaração de que nosso país, uma República Federativa, é formado "pela união indissolúvel dos Estados e Municípios e do Distrito Federal”. ${ }^{324}$ A aliança entre estes entes constitui a forma de organização política denominada Federação, que pode ser conceituada como a "união política e/ou econômica instituída entre estados relativamente autônomos, associados sob um governo central soberano". 325

Destarte, Federação representa um pacto, uma aliança entre Estados, que, sem perderem suas personalidades jurídicas, concedem determinadas prerrogativas a um novo Estado que surge, o Estado Federal, que representará a todos perante os Estados estrangeiros, sendo o único soberano. ${ }^{326}$

\footnotetext{
${ }^{324}$ Artigo $1^{\circ}$ da Constituição Federal de 1988.

${ }^{325}$ Verbete "federação", op. cit. (nota 54). Acesso em 13 de setembro de 2012.

${ }^{326}$ Cf. CARRAZZA, Roque, A., Curso de Direito Constitucional Tributário, Malheiros, São Paulo, 2008, p. 113.
} 
No federalismo, há uma repartição de competências estatais entre o órgão central, a União, e os Estados-membros, que vem esculpida no texto constitucional. ${ }^{327}$

Esta forma de organização de Estado, muito embora se apresente em apenas 24 dos 193 países do mundo, abrange cerca de $40 \%$ da população mundial. ${ }^{328}$ Entre os países que se estruturam por meio do federalismo estão os Estados Unidos, a Espanha, a Alemanha, a África do Sul, a Índia, a Austrália, o Paquistão, a Argentina e o Brasil, entre outros.

Em nosso país, a forma federativa de Estado é uma das cláusulas pétreas previstas no artigo $60, \S 4^{\circ}$ da Constituição Federal de 1988, não podendo, portanto, ser alterada nem mesmo por emenda constitucional tendente a aboli-la.

\subsection{A Federação em Três Níveis}

Podemos definir a "Federação Brasileira" como a forma de Estado cuja organização política é formada pela união de entes políticos dispostos em três níveis (União, Estados, Distrito Federal e Municípios), em que há um governo nacional (exercido pela União) e uma repartição de encargos e receitas, definindo o campo de atuação de cada membro federativo.

O constituinte originário de 1988 tentava retomar os fundamentos definidores do Estado Federal, devendo o mérito da reconstrução do federalismo ser-lhe atribuído. Mas ele foi além, introduzindo novos elementos e modernizando o federalismo constitucional brasileiro. Entre estes novos fundamentos, destaca-se a inclusão do Município entre os entes que compõem a Federação Brasileira, conforme dicção do artigo $1^{\circ}$ da CF 88, que não encontra correspondentes nas Constituições anteriores. ${ }^{329}$

$\mathrm{Na}$ verdade, inserir os Municípios entre os entes federativos significou uma inovação que não encontra correspondência em nenhuma outra Constituição Federal

${ }^{327}$ Cf. ZIMMERMANN, Augusto, Teoria Geral do Federalismo Democrático, Lumen Juris, 2a . ed., Rio de Janeiro, p. 40.

${ }^{328}$ Dados disponíveis em: 〈http://www.forumfed.org/en/federalism/by_country/index.php >. Acesso em $25 \mathrm{de}$ outubro de 2010.

${ }^{329}$ Cf. MACHADO, Raul Horta, Direito Constitucional, $3^{\mathrm{a}}$ ed. rev., atual. e ampl., Belo Horizonte, Del Rey, 2002, p. 446. 
no mundo. Esta conformação adveio da força do movimento municipalista que obteve sucesso em erigir o Município a ente autônomo e componente da República Federativa. ${ }^{330}$

Desde 1934, o Município vinha assumindo relevância na Constituição Federal, o que foi ampliado na CF 88, mas não justificava sua inclusão entre os entes federativos. ${ }^{331} \mathrm{O}$ constituinte de 1988, quando incluiu os Municípios entre as pessoas de Direito Público que integram a República, rompeu com todos os constituintes anteriores e colocou-se em posição única no conjunto das Constituições dos Estados Federais.

Destarte, a estrutura tridimensional é peculiaridade de nossa Federação, que é a única a garantir este status de unidade autônoma de poder aos Municípios. ${ }^{332}$ Em termos de competência legislativa, os Municípios podem legislar sobre assuntos de interesse local, sendo-lhes vedado, contudo, legislar de forma concorrente com a União e os Estados (art. 24, CF), cabendo-lhes somente suplementá-los no que for cabível (art. 30, II, CF). ${ }^{333}$

No entanto, a doutrina pátria se divide quanto ao fato de os Municípios comporem ou não a Federação brasileira, ainda que os artigos $1^{\circ}$ e 18 de nossa Constituição prevejam expressamente que estes entes também a compõem. ${ }^{334}$

Doutrinadores como Paulo de Barros Carvalho e Roque Carrazza, entre outros, defendem a ideia de que os Municípios são "entes autônomos" e não entes federativos, baseados no fato destes não possuírem representação no Senado Federal e nem Poder Judiciário Próprio.

Desta forma, os Municípios não possuiriam todas as características inerentes ao federalismo, quais sejam: “a) a repartição constitucional de competências (ou descentralização política constitucional); b) a participação da vontade das ordens jurídicas parciais na vontade da ordem jurídica nacional; e c) a possibilidade de autoconstituição (Constituições locais)". 335

${ }^{330}$ Cf. MACHADO, Raul Horta, op. cit. (nota 329), p. 446.

${ }^{331}$ Cf. Idem, ibidem, p. 332.

${ }^{332}$ Cf. ZIMMERMANN, Augusto, op. cit. (nota 327), p. 343.

${ }^{333}$ Cf. Idem, ibidem, p. 344.

${ }^{334} \mathrm{CF}$, Art. $1^{\circ}$ - "A República Federativa do Brasil, formada pela união indissolúvel dos Estados e Municípios e do Distrito Federal, constitui-se em Estado Democrático de Direito e tem como fundamentos". Art. 18. "A organização político-administrativa da República Federativa do Brasil compreende a União, os Estados, o Distrito Federal e os Municípios, todos autônomos, nos termos desta Constituição. (grifos nossos)".

335 VIEIRA, José Roberto, Princípios Constitucionais e Estado de Direito, Revista de Direito Tributário, Apud FERNANDES, Cintia E., IPTU - Texto e Contexto, p. 91. 
Neste sentido, Roque Carrazza entende que os Municípios, a despeito do que dispõe o art. $1^{\circ}$ da $\mathrm{CF}$, não fazem parte do pacto federativo, isto é, não integram a Federação, já que o próprio texto constitucional desmentiria solenemente o que prenuncia naquele artigo. Segundo o mestre, por não integrar o Congresso, nem possuir representantes no Senado, os Municípios não influem nem decidem na Federação Brasileira. ${ }^{336}$

Por outro lado, sobre a presença dos requisitos para a caracterização do Federalismo, e os Municípios brasileiros, Valéria Furlan entende que, ainda que uma Federação deva possuir requisitos mínimos, como duas ordens jurídicas, por exemplo, não há óbices para que, uma vez satisfeitos tais requisitos, possam haver características próprias, como a inclusão de entes de um outro nível, mesmo que sem representação no Senado, como o caso do Brasil. Para a autora, o fato de os Municípios possuírem competência e autonomia política para tratar de interesses locais confirma a tese de que, nos termos do artigo $1^{\circ}$ da nossa Constituição, integram a federação. ${ }^{337}$

Nas lições do mestre Paulo de Barros Carvalho deparamo-nos com o "princípio da isonomia das pessoas constitucionais", derivado da Federação e da autonomia dos Municípios, segundo o qual "a isonomia das pessoas constitucionais União, Estados e Municípios - é uma realidade viva da conjuntura normativa brasileira”. 338

Para o autor, no entanto, os Municípios não integram a Federação brasileira, composta, segundo ele, apenas pela União e pelos Estados, ainda que possuam personalidade política e gozem de imunidade. A referência do constituinte aos municípios os teria elevado e parificado aos outros membros, ressaltando ainda que não se tratam de entes menores, mas sim "pessoas jurídicas de direito constitucional interno, dotadas de representação política própria e que vão haurir competências privativas na mesma fonte em que o fazem as outras, isto é, na Lei Fundamental”. ${ }^{339}$

Reconhece finalmente Paulo de Barros a isonomia das pessoas constitucionais, enfatizando o fato de que juridicamente não há hierarquia, ou seja, que nenhuma se sobrepõe às demais.

\footnotetext{
${ }^{336}$ Cf. CARRAZZA, Roque, A., op. cit. (nota 326), p.162.

${ }^{337}$ Cf. FURLAN, Valéria, Imposto Predial e Territorial Urbano, São Paulo, Malheiros, 2004, p. 36.

${ }^{338}$ CARVALHO, Paulo de Barros, Curso de Direito Tributário, São Paulo, Saraiva, 2007, p. 150.

${ }^{339}$ Cf. Idem, ibidem, p. 152.
} 


\subsubsection{Autonomia Municipal}

O princípio da autonomia municipal tem sua origem no teor dos artigos 29 e 30 da Constituição Federal, que, respectivamente, determina sua forma de organização política e de regulamentação por Lei Orgânica e atribui competências regulamentares e administrativas.

Segundo Roque A. Carrazza, "autonomia municipal” "é a faculdade que a pessoa política Município tem de, dentro do círculo de competência pré-traçado pela Constituição, organizar, sem interferências, seu governo e estabelecer, sponte propria, suas normas jurídicas". 340

Esta autonomia seria tão expressiva que não caberia a nenhum poder ou autoridade mitigá-lo ou derrogá-lo. ${ }^{341}$ A despeito disso, Carrazza já defendeu a ideia de que tal autonomia não constituiria cláusula pétrea, de maneira que poderia o poder constituinte derivado diminuí-la ou até mesmo eliminá-la. Atualmente, no entanto, para o autor a Autonomia Municipal constitui cláusula pétrea, considerando que não faria sentido a Constituição Federal outorgar poder constituinte derivado aos Municípios (aprovar Lei Orgânica) e ao mesmo tempo conceder ao constituinte derivado o poder de extirpar-lhes a aptidão para se autogovernarem. ${ }^{342}$

O ponto fundamental do conceito de autonomia é a acepção e o alcance da faculdade legislativa dos Municípios. Ainda que tal faculdade não seja soberana, já que deve ater-se aos limites impostos pelo próprio texto constitucional, não pode ser tomada apenas como a capacidade de instituir tributos.

Tampouco pode a autonomia municipal ser encarada somente como a prerrogativa de decidir sobre a alocação de recursos recebidos por meio de repasse de outros entes federativos.

À medida que os municípios possuem competência legislativa, estão habilitados a implementar políticas públicas, urbanas, sociais e até tributárias independentes, moldadas a seus interesses locais, como, por exemplo, conceder incentivos fiscais a empresas visando, por exemplo, a reurbanizar áreas deterioradas da cidade.

${ }^{340}$ CARRAZZA, Roque, A., op. cit. (nota 326), pp.163/164.

${ }^{341}$ Cf. Idem, ibidem, p. 161.

${ }^{342}$ Cf. Idem, ibidem, p.163. 


\subsubsection{O Município na Federação perante as Constituições Brasileiras}

Os Municípios no Brasil Colônia desfrutavam de franquias largas e "relevantes atribuições de governo, de administração e de justiça". As municipalidades realizavam obras, estabeleciam posturas, fixavam taxas, faziam nomeações de vários cargos (juízes-almotacéis, recebedores de tributos, depositários públicos, avaliadores de bens penhorados, entre outros) e chegavam a convocar "juntas do povo" para discutir e deliberar sobre interesses da Capitania. ${ }^{343}$

A Constituição Imperial de 1824 deu novas diretrizes aos Municípios, que foram contemplados com a instituição de Câmaras Municipais em todas as cidades e vilas, competindo-lhes "o governo econômico e municipal, [...] especialmente o exercício das funções municipais, formação de suas posturas policiais, aplicação de suas rendas e todas as suas particularidades e úteis atribuições, a serem regulamentadas por lei ordinária (art. 169)." ${ }^{344}$ No entanto, estas atribuições não significavam que os Municípios passaram a ter autonomia na gestão de seus interesses, pois imperava um centralismo provincial, que desprestigiava os governos regionais, sendo que poucos foram os atos de autonomia das municipalidades, que não passavam então de meras divisões territoriais, sem influência política. ${ }^{345}$

Os primeiros fundamentos do federalismo no Brasil surgiram no sistema constitucional tributário republicano de 1891, que erigiu um novo sistema tributário propriamente dito, lançando as bases para a discriminação de rendas e contemplando a autonomia financeira dos novos Estados. ${ }^{346}$

Tratou aquela Constituição de discriminar os tributos de competência da União e dos Estados, não havendo ainda nenhuma disposição direta e expressa neste sentido relativamente aos Municípios, tendo-lhes sido assegurada, pelo artigo 68, uma forma de organização dos Estados para garantir-lhes "em tudo o que respeite ao seu

${ }^{343}$ MEIRELLES, Hely Lopes, Direito Municipal Brasileiro, 15 a ed., atual., São Paulo, Malheiros, 2007, pp. 35-37.

${ }^{344}$ Idem, ibidem, p. 37.

${ }^{345}$ Cf. Idem, ibidem, p. 37.

${ }^{346}$ Cf. ATALIBA, Geraldo, Sistema Constitucional Tributário Brasileiro, São Paulo, Revista dos Tribunais, 1968, pp. 50-51. 
peculiar interesse". 347 Com base nisto, cada Estado modelou seus Municípios com amplitudes maiores ou menores, sendo suas autonomias e atribuições reafirmadas pelas leis orgânicas. Mas esta autonomia ficou relegada apenas às normas.

Ou seja, naquele sistema tributário federal, os municípios significavam "mera repartição administrativa do Estado, integralmente sujeita a seus desígnios, em matéria financeira." 348 Segundo Geraldo Ataliba, isto significou uma involução face ao sistema imperial, que tinha como polos a capital e os municípios, relegando as Províncias a entes de menor importância, já que os municípios teriam sido destituídos no sistema republicano de sua dignidade constitucional. ${ }^{349}$

Não teria havido autonomia municipal durante a vigência desta Constituição, não passando os Municípios de feudos de políticos ditatoriais, que os consideravam como propriedade particular, tudo causado pelo centralismo político, o coronelismo e a incultura do povo. ${ }^{350}$

$\mathrm{O}$ robustecimento da consciência municipalista, aliado à experiência federalista acumulada desde a primeira Constituição da Republica até a segunda, em 1934, demonstravam a necessidade de disciplinar no Texto Magno a repartição de competências impositivas, visando a evitar conflitos entres seus entes, que refletiram sobremaneira na Constituinte de $1934 .{ }^{351}$

Houve na Carta Magna de 1934 o reconhecimento da entidade política municipal, que passou a ser incluída na complexa e já problemática discriminação de rendas. Assim, segundo Ataliba, o campo tributário é repartido "em termos mais racionais" entre a União, os Estados e os Municípios, assumindo a autonomia municipal uma condição essencial à sua subsistência. ${ }^{352}$

Considera-se que ocorreu, assim, um renascimento do municipalismo, auxiliado pela consciência da necessidade de rendas próprias, que assegurassem a realização de seus encargos públicos, como único caminho para outorgar-lhes a autonomia e garantir-lhes o progresso material. ${ }^{353}$

\footnotetext{
${ }^{347}$ ATALIBA, Geraldo, op. cit. (nota 346), p. 53.

${ }^{348}$ Idem, ibidem, p. 56.

${ }^{349}$ Cf. Idem, ibidem, p. 56.

${ }^{350}$ MEIRELLES, Hely Lopes, op. cit. (nota 343), p. 39.

${ }^{351}$ ATALIBA, Geraldo, op. cit. (nota 346), p. 57.

${ }^{352}$ Idem, ibidem, pp. 57-58.

${ }^{353}$ MEIRELLES, Hely Lopes, op. cit. (nota 343), p. 40.
} 
Neste sentido, o artigo 13 da Constituição de 1934 consagrava o princípio da autonomia dos Municípios "em tudo quanto respeite ao seu peculiar interesse, e especialmente a eletividade do prefeito e dos vereadores, a decretação de seus impostos e a organização de seus serviços." ${ }^{354}$ O mesmo artigo discriminava ainda as rendas dos Municípios, sendo a primeira vez que uma Constituição detalhou tal assunto, visando a garantir um princípio que havia sido relegado até então somente aos atos normativos. ${ }^{355}$

Posteriormente, a CF 37, que criou o Estado Novo, feriu profundamente a autonomia municipal, posto que se caracterizava pela concentração de poderes no Executivo, e era um misto de corporativismo e socialismo. A eletividade dos prefeitos foi cassada, sendo mantida a discriminação de rendas como instituída na Constituição anterior. Hely Lopes Meirelles afirma que os Municípios foram menos autônomos neste período do que no centralismo imperial, já que na Monarquia os assuntos locais eram debatidos nas Câmaras de Vereadores, ao passo que no Estado Novo os prefeitos nomeados governavam discricionariamente, sem qualquer participação popular. ${ }^{356}$

Após este período, o municipalismo ganhou nova força na Constituição de 1946, sob os aspectos político, administrativo e financeiro, tendo ocorrido a descentralização da administração, repartida então entre a União, os Estados-membros e os Municípios, preservando a Federação e a autonomia estadual e municipal. Para tanto, os arts. 29 e 30 garantiam a repartição de receitas públicas aos Municípios, que eram discriminadas de forma a limitar a atuação do legislador ordinário. ${ }^{357}$

A Constituição Federal de 1967 e a Emenda Constitucional de 1969 - EC 69, outorgadas após o golpe militar de 1964, significaram nova centralização política do Executivo e, ainda que tenham sido mantidos os princípios da Federação e da autonomia estadual e municipal, o foram de forma mais restrita. Os atos institucionais e emendas que vieram em seguida limitaram ainda mais a atuação municipal sob os aspectos político, administrativo e financeiro. ${ }^{358}$

Foram discriminados na EC de 69 os tributos sob a competência dos Municípios, o Imposto Predial e Territorial Urbano - IPTU e o Imposto sobre Serviços ISS, mas a tarefa de estabelecer as "normas gerais de direito tributário" e a regulamentação

\footnotetext{
${ }^{354}$ Constituição Federal 1934, art. 13.

355 MEIRELLES, Hely Lopes, op. cit. (nota 343), p. 40.

${ }^{356}$ Idem, ibidem, p. 41.

${ }^{357}$ Cf. MEIRELLES, Hely Lopes, op. cit. (nota 343), p. 42.

${ }^{358}$ Cf. Idem, ibidem, p. 43.
} 
das "limitações constitucionais ao poder de tributar" foi atribuída à lei complementar federal (artigo 18). A competência para instituição de taxas e contribuições de melhoria foi mantida e concedeu-se a participação dos Municípios na arrecadação dos impostos federais e estaduais. Segundo Hely Lopes Meirelles, esta Constituição teve o mérito de promover uma melhor distribuição de rendas entre as esferas federativas e de corrigir distorções da tributação municipal com as limitações estabelecidas, impedindo a proliferação de taxas e impostos que tinham o mesmo fato gerador, diferenciados apenas pela denominação. ${ }^{359}$

Mas foi a atual Constituição de 1988 que alçou o município à "entidade de terceiro grau" e ampliou sua autonomia sob os aspectos político (extinguiu a nomeação de prefeitos, manteve a eleição direta de vereadores), administrativo (poder de elaborar sua lei orgânica e competência privativa para assuntos "de interesse local”) e financeiro (aumento da participação na partilha de receitas). ${ }^{360}$

\subsubsection{Autonomia Municipal: Limites}

A doutrina cita a autonomia dos entes federativos como uma das características que fundamentalmente encontra-se em toda e qualquer forma de Federalismo. ${ }^{361}$ Esta autonomia surge como corolário do próprio princípio Federativo, assim entendidas as prerrogativas contidas nas competências legislativas, administrativas e tributárias, outorgadas pela Carta Magna.

Segundo Hely Lopes Meirelles, a autonomia municipal pressupõe como conteúdo mínimo quatro aspectos: (i) poder de auto-organização, representado pela capacidade de elaborar lei orgânica própria; (ii) poder de autogoverno, relacionado à efetividade do prefeito, do vice e dos vereadores; (iii) poder de autolegislação, ligado às suas competências exclusiva e suplementar; e (iv) poder de autoadministração, integrando

${ }^{359}$ Cf. MEIRELLES, Hely Lopes, op. cit. (nota 343), p. 44.

${ }^{360}$ Idem, ibidem, p. 45.

${ }^{361}$ Dentre eles, CONTI leciona que são fundamentalmente as seguintes as características de todo e qualquer Federalismo: (i) a existência de, no mínimo, duas esferas governamentais; (ii) a autonomia política, administrativa e financeira das entidades descentralizadas; (iii) a organização do Estado expressa em uma Constituição; (iv) a repartição de competência entre as entidades descentralizadas; (v) a participação das entidades descentralizadas na formação da vontade nacional; (vi) e a indissolubilidade. CONTI, José Maurício, Federalismo fiscal e fundos de participação, São Paulo, Juarez de Oliveira, 2001. 
a administração própria para criar, manter e prestar os serviços de interesse local, assim como legislar sobre seus tributos e a aplicação de suas rendas. ${ }^{362}$

A autonomia política pressupõe, segundo Geraldo Ataliba, necessariamente, a autonomia financeira, com a existência de fontes juridicamente próprias de receita, já que

onde existir a verdadeira e efetiva autonomia - não em meros termos de anseio político ou ideal administrativo, mas - traduzida em regime jurídico que confere poder decisório próprio, por órgãos próprios, aí se vê nítida autonomia financeira, sem a qual, aliás, eufêmica seria a própria qualificação autonômica. ${ }^{363}$

Compreender a real importância do princípio federativo possibilita alcançar a extensão do significado da competência legislativa concedida a cada membro da Federação. A exegese do art. 24, I da CF, combinada com o art. 145 do mesmo diploma, é clara no sentido de que todos os entes da Federação têm o direito de legislar concorrentemente sobre direito tributário e instituir tributos.

Para Hely Lopes Meirelles, a autonomia concedida aos Municípios não é tão ampla como a dos outros entes federativos, o que, contudo, não descaracteriza "sua natureza de entidade estatal, com poderes políticos suficientes para elaborar suas leis (Poder Legislativo) e para convertê-las em atos individuais e concretos (Poder Executivo).” No entender do mestre, o Município constitui na Federação Brasileira "entidade estatal de terceiro grau, ante a outorga de personalidade jurídica, governo próprio e competência normativa". ${ }^{364}$ E mais, representa "um verdadeiro direito público subjetivo, oponível ao próprio Estado (União), sendo inconstitucionais as leis que, de qualquer modo, o atingirem em sua essência”. 365

\footnotetext{
${ }^{362}$ MEIRELLES, Hely Lopes, op. cit. (nota 343), p.93.

${ }^{363}$ ATALIBA, Geraldo, op. cit. (nota 346), p. 24.

${ }^{364}$ MEIRELLES, Hely Lopes, op. cit. (nota 343), p.130.

${ }^{365}$ Idem, ibidem, pp. 91-92.
} 


\subsubsection{Proliferação de municípios após a CF/88}

Na exposição de motivos do Código Tributário Nacional, Lei no 5.172 de 25 de outubro de 1966, Rubens Gomes de Sousa já demonstrava preocupação pelo fato de haver, concomitantemente no país, mais de 2 mil aparelhos fiscais. ${ }^{366}$

Mas a proliferação de municípios no Brasil deu-se após a promulgação da $\mathrm{CF}$ de 88 , que confiou aos Estados-membros a decisão política relativa à criação de novas unidades federativas, assim como a disciplina normativa do seu processo, conforme texto original do $\S 4^{\circ}$ do art. 18 da Carta Magna de $1988 .{ }^{367}$

Os resultados foram considerados desastrosos, já que as assembleias legislativas por uma natural incapacidade de resistir aos movimentos emancipacionistas acabaram por elevar à condição de ente federativo municípios inviáveis, sem a mínima condição de autossustentabilidade, demonstrando-se uma fonte de distorção. ${ }^{368}$

A redação do parágrafo $4^{\circ}$, do artigo 18 , da Constituição Federal foi alterada pela Emenda Constitucional (EC) nº 15, de 12 de setembro de 1996, que dispôs sobre a criação, a incorporação, a fusão e o desmembramento de municípios, determinando que os atos relativos a estes processos sejam confirmados por meio da edição de lei estadual "em período determinado por lei complementar federal". Além disto, tais atos devem ser precedidos da realização de estudos de sua viabilidade, dependendo ainda de consulta prévia às populações dos municípios envolvidos por meio de plebiscito. A referida Emenda Constitucional foi objeto de Ação Direta de Inconstitucionalidade - ADI 2395, requerida pela Assembleia Legislativa do Rio Grande do Sul (AL-RS).

366 Cf. SANTI, Eurico Marcos Diniz de, O Código Tributário Nacional e as Normas Gerais de Direito Tributário, in Curso de Direito Tributário e Finanças Públicas - do fato à norma, da realidade ao conceito jurídico, SANTI, Eurico Marcos Diniz, (Coordenador) São Paulo, Saraiva, 2008, p. 326. O Brasil hoje possui mais de 5565 Municípios.

${ }^{367}$ CF 88, Art. 18, § $4^{\circ}$ - Redação Original "A criação, a incorporação, a fusão e o desmembramento de Municípios preservarão a continuidade e a unidade histórico-cultural do ambiente urbano, far-se-ão por lei estadual, obedecidos os requisitos previstos em Lei Complementar estadual, e dependerão de consulta prévia, mediante plebiscito, às populações diretamente interessadas". Nova redação dada pela Emenda Constitucional no 15 , de 1996 - " $\$ 4^{\circ}$ A criação, a incorporação, a fusão e o desmembramento de Municípios far-se-ão por lei estadual, dentro do período determinado por Lei Complementar Federal, e dependerão de consulta prévia, mediante plebiscito, às populações dos Municípios envolvidos, após divulgação dos Estudos de Viabilidade Municipal, apresentados e publicados na forma da lei” (g.n).

${ }^{368}$ Cf. MEIRELLES, Hely Lopes, op. cit. (nota 343), p. 65. 
No voto da ADI, o relator mencionou manifestação da Advocacia Geral da União, que se referia à tal permissão como "anomalia fática permitida pelo texto constitucional originário," 369 na medida em que permitiu a reprodução desmedida destes entes políticos, o que teria afetado a própria estrutura da federação, tudo movido por interesses meramente políticos. A experiência tem demonstrado que a criação desmedida de novos Municípios sem condições de vida autônoma prejudica aqueles já existentes, na medida em que os enfraquece economicamente. ${ }^{370}$

Os motivos da alteração promovida pela $\mathrm{EC}^{\circ} 15$ podem ser esclarecidos na Proposta à Emenda no 22, citada pelo relator no julgamento da ADI 2.395/SF; segundo aquele documento, o aparecimento de um grande número de Municípios no país tinha um caráter essencialmente eleitoreiro, e que teriam ocorrido verdadeiros abusos. ${ }^{371}$

Impende ressaltar que, ainda que o Supremo Tribunal Federal - STF tenha entendido pela constitucionalidade da referida emenda, e de que não teria havido violação ao principio federativo, vários ministros ressaltaram em suas manifestações a importância da autonomia dos Municípios conforme concebido pela Constituição Federal, que deve ser compatibilizada, contudo, com sua capacidade de autossustentação.

\subsubsection{Os Municípios no atual cenário brasileiro}

O cenário nacional revela uma grande diversidade socioeconômica entre os atuais 5.565 municípios brasileiros. Segundo dados do $\mathrm{IBGE}^{372}$, quase $50 \%$ deles possuem até 20 mil habitantes e $90 \%$ até 50 mil habitantes. Por outro lado, grandes cidades como São Paulo albergam mais de 11 milhões de habitantes.

Segundo aquele instituto, os dados relativos à população podem ser indicadores importantes para a caracterização da identidade municipal; de fato, segundo estudos ${ }^{373}$, a participação da receita tributária própria na receita orçamentária total do

369 ADI 2395/DF, trecho do voto do relator, p. 131. Disponível em: <http://redir.stf.jus.br/paginador/paginador.jsp?docTP=AC\&docID=528743 >. Acesso em 13 de novembro de 2010.

${ }^{370}$ Cf. MEIRELLES, Hely Lopes, op. cit. (nota 343), p. 67.

371 ADI 2395/DF, trecho do voto do relator, p. 134. Disponível em: <http://redir.stf.jus.br/paginador/paginador.jsp?docTP=AC\&docID=528743 >. Acesso em 13 de novembro de 2010.

${ }^{372}$ Disponível em <http://www.ibge.gov.br>. Acesso em 28 de agosto de 2010.

${ }^{373}$ Segundo estudo técnico desenvolvido pela ONG Transparência Municipal, disponível em: <http://www.oim.tmunicipal.org.br/abre documento.cfm?arquivo=_repositorio/_oim/_documentos/772B 
município se eleva na medida em que aumenta seu porte demográfico. Isto pode ser explicado pelo fato de que os índices de receita tributária própria relacionam-se intimamente à urbanização e à concentração de atividades econômicas na unidade geográfica.

Neste sentido, Zimmerman leciona que apesar de a CF 88 haver ampliado a participação dos Municípios na receita tributária, esta ainda representa uma percentagem comparativamente pequena frente àquela da União e dos Estados. Segundo o autor, a grande maioria dos municípios tem menos de 20 mil habitantes, não dispondo de recursos humanos ou financeiros capazes para exercer os encargos outorgados pela Magna Carta. ${ }^{374}$ Estes municípios, principalmente os da região norte, nordeste, centro-oeste e sul, sobrevivem à custa de repasses dos outros entes federativos, garantidos pela Constituição, já que a arrecadação própria é praticamente inexistente.

Em contrapartida, o Município de São Paulo, por exemplo, possui a terceira arrecadação tributária em nível nacional, atrás apenas da União e do Estado de São Paulo, revelando que convivem no país municípios com realidades antagônicas e dados socioeconômicos desproporcionais.

Dados do censo do IBGE que avaliam o PIB dos municípios brasileiros revelam que apenas seis municípios concentram cerca de $25 \%$ de toda a geração de renda do país. São Paulo fica no topo da lista, com 11,8\% de participação no PIB (Produto Interno Bruto) nacional, seguido por Rio de Janeiro (5\%), Brasília (4\%), Curitiba (1,4\%), Belo Horizonte $(1,4 \%)$ e Manaus (1,3\%). Juntas, as seis capitais representam 13,5\% da população e têm a maior concentração da atividade no setor de serviços. ${ }^{375}$

As receitas tributárias próprias dos Municípios em 2009 representaram, na média nacional, apenas $17,22 \%$ de suas receitas orçamentárias, com exceção da região sudeste onde atingiram quase $23 \% .{ }^{376}$ Por outro lado, na região nordeste este percentual não atingiu $9 \%$.

EFF2-97EB-A456-AC5D09788463BB7D04102010091629.PDF\&i=1215>. Acesso em $1^{\circ}$ de novembro de 2010.

${ }^{374}$ Cf. ZIMMERMANN, Augusto, op. cit. (nota 327), p. 344.

375 Dados do Censo do IBGE Produto Interno Bruto dos Municípios em 2010. Disponível em: $<$ http://www.ibge.gov.br/home/estatistica/economia/pibmunicipios/2010/>. Acesso em 12 de dezembro de 2012.

${ }^{376}$ BREMAEKER, Francois E. J, op. cit. (nota 16). Acesso em 22 de outubro de 2010. 
Para que se possa avaliar o potencial arrecadatório dos municípios e estabelecer um parâmetro de comparação, no Município de São Paulo, no mesmo período, a receita tributária própria significou $44,3 \%$ da receita total. ${ }^{377}$

Outro índice que demonstra a disparidade existente entre os municípios brasileiros é o do total de receitas tributárias municipais por região, já que mais de $66 \%$ se concentram apenas nos municípios da região sudeste, provavelmente em função das cidades de São Paulo e Rio de Janeiro ${ }^{378}$. Isto espelha não apenas a realidade nacional, mas o fato de que nem todos os municípios têm desempenhado suas competências tributárias de forma a garantir uma autossustentabilidade, assim como evidencia as diferenças socioeconômicas entre as diversas regiões do país.

Os municípios da região sul, que ocupam o segundo lugar neste ranking com $15,4 \%$ da receita total, são os que mais se aproximam da média brasileira, seguidos por aqueles da região centro-oeste, que ficam bem abaixo da média nacional. Quanto às regiões norte e nordeste, estas apresentam as receitas tributárias per capita mais modestas, num patamar quase três vezes menor que a média dos Municípios do país. Vale dizer, os Municípios da região nordeste concentravam $11,25 \%$ de toda a receita tributária municipal do país em 2009, os da região centro-oeste, 4,53\% e os da região norte, 3,64\%. ${ }^{379}$

Se considerarmos que os municípios são os entes que experimentam mais diretamente as pressões populares, percebendo de maneira mais próxima suas insatisfações, deveriam estes entes dispor de recursos suficientes que lhes permitissem implementar os encargos e políticas de interesse local. Sob este prisma, reforçar a autossuficiência destes entes significaria reduzir suas carências de recursos, convertendoos numa administração local mais responsável e presente. ${ }^{380}$

\subsubsection{Autonomia e Receita Tributária própria: análise de caso}

Gozar de "autonomia para instituir e arrecadar tributos" vai muito além de possuir autonomia para gerir e gastar repasses. O poder de editar normas em matéria

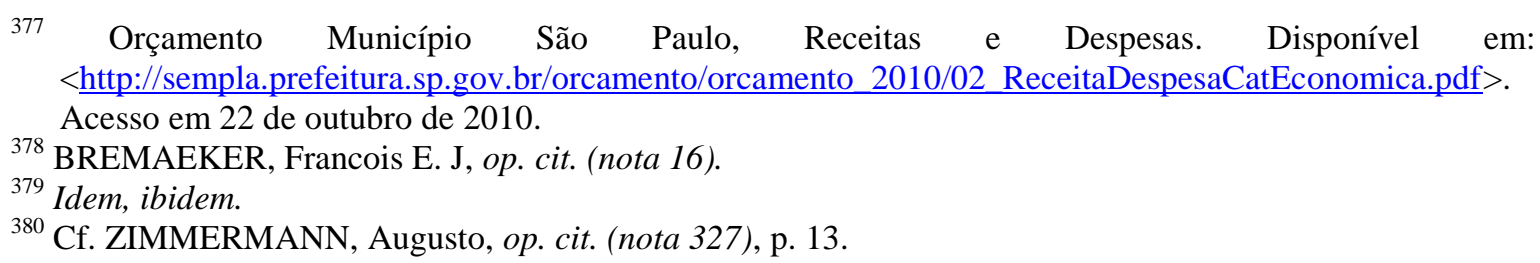


tributária concede ao ente a possibilidade de implementar políticas públicas e adotar estratégias que lhe permitam incrementar o orçamento muito acima de índices inflacionários, autorizando-lhe a aplicar na cidade e retornando ao contribuinte mais e melhores serviços públicos.

Comparando-se dados relativos à evolução da receita tributária própria e dos repasses recebidos pelo Município de São Paulo, que vem realizando uma política tributária usando os mais variados mecanismos, é possível demonstrar que a autonomia para instituir tributos não pode ser equiparada à autonomia financeira, enquanto mera administração de repasses.

No período de 2004 a 2011, enquanto a arrecadação dos tributos repassados ao Município apresentou variação real de 44\% no ICMS e de 56\% no IPVA, os impostos municipais demonstraram um melhor desempenho, com um aumento real de 115\% na arrecadação do ISS e de $198 \%$ na do ITBI-IV - Imposto sobre Transmissão de Bens Imóveis Inter Vivos. Considerando o repasse total dos tributos estaduais recebido pelo município (ICMS + IPVA), a expansão real foi de 67,9\% de 1996 a 2011, 24\% abaixo da expansão da arrecadação total dos tributos municipais em termos reais. ${ }^{381}$

No Município de São Paulo, enquanto a evolução nominal da arrecadação do ISS de janeiro de 1996 a dezembro de 2011 apresentou um incremento de $560,4 \%$, a inflação apontada pelo índice IPCA - IBGE no mesmo período foi de $173,47 \%{ }^{382}$ Tal desempenho decorreu da adoção de medidas antielisivas, que não se limitaram apenas ao aumento de alíquota do referido imposto.

O aumento na arrecadação de ISS no município saltou de cerca de 1,2 bilhões de reais em 1996 para quase oito bilhões em 2011, fato atribuído à edição da Lei Complementar $\mathrm{n}^{\circ} 116$ e à adoção e implementação de medidas como a Declaração Eletrônica de Serviços, o Cadastro de Prestadores de Serviços de Outros Municípios ${ }^{383}$, o Parcelamento Administrativo, a Nota Fiscal Eletrônica de Serviços e a Declaração de Instituições Financeiras, entre outras.

No mesmo diapasão, a arrecadação municipal com o IPTU saltou de cerca de 660 milhões de reais em 1996 para 4,5 bilhões de reais em 2011, beneficiada por

\footnotetext{
381 Orçamento Município São Paulo, Receitas e Despesas. Fonte: Secretaria de Finanças SP.

${ }^{382}$ IBGE/Metadados, Séries Estatísticas. Disponível em: <http://seriesestatisticas.ibge.gov.br/>. Acesso em 26 de novembro de 2012. Considerando-se o índice do IPCA, o aumento real da receita foi de $163 \%$.

${ }^{383}$ O Cadastro de Prestadores de Outros Municípios - CPOM - foi introduzido pela Lei Municipal n ${ }^{\circ} 14.042$, de 30.08.2005.
} 
medidas como a revisão da Planta Genérica de Tributos, a adoção do Cadastro de Inadimplentes e o recadastramento da totalidade dos contribuintes.

Por outro lado, a participação do mesmo Município no repasse da receita do ICMS, que era em 1970 de 48\% do total arrecadado no Estado, caiu para 23,4\% em 2011. No período entre 2002 a 2009, em que analisamos a evolução da receita própria, a queda no repasse do ICMS foi de $6,8 \%$.

Estes repasses, previstos no art. 157 da CF, são compostos, em sua maior parte $(76 \%)$, pela relação entre o valor adicionado em cada município e o valor total do Estado nos dois exercícios anteriores ao da apuração. O restante toma por base o percentual entre a população de cada município e a população total do Estado (13\%), o percentual entre o valor da receita tributária própria de cada município e a soma da receita tributária própria de todos os municípios paulistas (5\%), área cultivada (3\%), o resultado da divisão do valor correspondente a $2 \%$ pelo número de municípios do Estado existentes em 31 de dezembro do ano anterior ao da apuração (2\%) e áreas preservadas e inundadas (05,\% cada). ${ }^{384}$

Apesar de São Paulo ser o Estado da Federação que atribui o maior peso ao dado populacional na composição dos repasses, ainda assim ocorre nesta distribuição uma distorção causada pelo baixo peso concedido, de modo geral, à população em relação a outros fatores. Desta forma, a cidade de Paulínia, cujo território abriga um polo petroquímico, apesar de contar com apenas $0,14 \%$ da população do Estado, recebe 2,85\% na quota-parte do ICMS, a quarta maior, superando, inclusive, a quota recebida por Campinas $(2,67 \%)$ com $2,62 \%$ da população. Enquanto isso, cidades vizinhas com cerca de três vezes a população de Paulínia não chegam a receber um quarto de sua quota-parte. Em termos absolutos, note-se que em 2010, enquanto a receita per capita de tal repasse foi de apenas 410 reais na Capital, chegou a 8 mil reais no município de Paulínia.

A correção desta distorção foi contemplada na Proposta de Emenda Constitucional - PEC 233, que propõe que o critério de partilha municipal da parcela de ICMS, atualmente transferida com base no valor adicionado, passe a ser definido por lei

384 Lei Estadual de São Paulo n. 8.510, de 29.12.1993, que dispõe sobre a parcela, pertencente aos municípios, do produto da arrecadação do Imposto sobre Operações Relativas à Circulação de Mercadorias e sobre Prestações de Serviços de Transporte Interestadual e Intermunicipal e de Comunicação - ICMS. 
complementar, recomendando que haja uma transição longa na mudança, que não afete ou comprometa a estabilidade das finanças municipais. ${ }^{385}$

Segundo a Cartilha da Reforma Tributária ${ }^{386}$, editada pelo governo federal, o critério atual de distribuir três quartos dos recursos proporcionalmente ao valor adicionado em cada Município gera um grande desequilíbrio na repartição dos recursos entre os Municípios, beneficiando desproporcionalmente aqueles onde estão localizadas grandes unidades industriais, em detrimento dos demais. Ainda segundo aquele documento, "um Município chega a receber 130 vezes mais que outro em transferências de ICMS por habitante. A consequência é uma situação em que sobram receitas em alguns Municípios, ao mesmo tempo em que outros enfrentam uma enorme carência de recursos". 387

Os critérios de definição dos repasses da União aos Estados privilegiam as unidades economicamente mais vulneráveis, de forma que há um descompasso entre os valores arrecadados pela União em cada Estado federado e aqueles posteriormente repassados a cada um deles. A "razão federativa", índice elaborado para embasar um estudo sobre os royalties de petróleo, permite avaliar a relação entre o valor arrecadado pela União em tributos em cada uma das unidades da federação e a receita posteriormente repassada a cada uma delas. ${ }^{388}$ Considerando-se as transferências da União para os Estados e Municípios por unidade da federação ${ }^{389}$ e o valor arrecadado em tributos ${ }^{390}$ efetuado nas mesmas regiões, estabeleceu-se uma razão entre o que o governo federal retorna como repasse relativamente àquilo que arrecada em cada território.

Por óbvio que o resultado menor que a unidade revela que o governo central arrecada mais em determinada região do que lhe retorna em repasses; ao contrário,

385 Cartilha da Reforma Tributária. Disponível em: <http://www.fazenda.gov.br/portugues/documentos/2008/fevereiro/Cartilha-Reforma-Tributaria.pdf>. Acesso em 2 de novembro de 2010.

${ }^{386}$ Ibidem. Acesso em 02 de novembro de 2010.

${ }^{387}$ Ibidem. Acesso em 02 de novembro de 2010.

388 CASTRO, Kleber Pacheco, Tributação do Setor de Petróleo: evolução e perspectivas, in <http://www.esaf.fazenda.gov.br/esafsite/Biblioteca/arquivos/100616-ESAFTributacaoPetroleo.pdf>.

Acesso em 5 de novembro de 2010.

389 Disponível em: <http://www.stn.fazenda.gov.br/estados_municipios/transferencias constitucionais.asp >. Acesso em 5 de novembro de 2010. As transferências da União para estados e municípios consideradas no estudo incluem: FPE, Fundeb União-Estados, IPI-Exportação, LC 87/96 (Desoneração do ICMS)Estados, FEX-Estados, Cide-Estados, Fundo Constitucional do Distrito Federal, FPM, Fundeb UniãoMunicípios, IOF, ITR, LC 87/96 (Desoneração do ICMS)-Municípios, FEX-Municípios, CideMunicípios e AFM.

390 Disponível em <http://www.receita.fazenda.gov.br/Historico/Arrecadacao/PorEstado/default.htm >. Acesso em 5 de novembro de 2010. 
o indicador maior que a unidade denota que o governo central mais envia verbas por repasse do que os valores obtidos com os tributos naquela região.

Analisando os dados relativos a tal índice no país, pode-se verificar que, para a maioria das unidades da federação, o índice é maior que um, indicando que a União repassa mais verbas do que arrecada em boa parte dos Estados. Já para as unidades mais desenvolvidas economicamente, o índice é menor que um, decrescendo na medida em que o Estado tem uma economia mais forte, em especial para os Estados de São Paulo e Rio de Janeiro. $^{391}$

Ou seja, os Estados que mais contribuem na arrecadação da União são os que recebem, proporcionalmente, os menores repasses, demonstrando que uma reforma tributária que, hipoteticamente, retire dos entes todas suas competências para a instituição de tributos, baseando-se unicamente em repasses para seus entes, terá nesta política de repasses o ponto fulcral.

Na situação atual, cada Estado sente-se explorado ou prejudicado pelos demais na repartição dos recursos. O Fundo de Participação dos Estados - FPE é distribuído por critérios contestados, principalmente, pelos Estados do sul do país já que aqueles do norte ficam com $85 \%$ do bolo. Por outro lado, estes se sentem lesados por recolher para aqueles o ICMS na compra de seus produtos. Ou seja, com o sistema vigente de repartição de receitas ocorre toda sorte de desconfiança e acusações recíprocas. ${ }^{392}$

A longo prazo, uma política unicamente de repasses que mantenha a tendência atual de distribuição levaria os Estados mais desenvolvidos e economicamente mais fortes a receber menos do que proporcionam em receitas, o que somente se justificaria por uma política de solidariedade entre os entes federativos. No entanto, não se pode descuidar de que a $\mathrm{CF}$ estabeleceu, paralelamente às competências tributárias, uma série de encargos que devem os entes arcar, ligados à educação, saúde e outros, para os quais necessitam de ingressos e que guardam relação com uma série de fatores, que não apenas o populacional.

Destarte, qualquer alteração no sistema tributário atual, deve considerar que a Constituição Federal definiu um verdadeiro sistema de receitas e encargos para os entes federativos e que a supressão de um de seus elementos pode levar ao desequilíbrio do

${ }^{391}$ CASTRO, Kleber Pacheco, op. cit. (nota 388). Acesso em 5 de novembro de 2010.

${ }^{392}$ Cf. ZIMMERMANN, Augusto, op. cit. (nota 327), p. 354. 
sistema como um todo, atingindo, ainda que de forma oblíqua, a autonomia dos entes federativos.

\subsection{Competência Tributária: Conceito e Acepção}

"Competência" é um daqueles vocábulos plurívocos que admitem vários significados, por isso, adotaremos no presente estudo aquela acepção relativa à "norma que delimita a pessoa ou órgão de direito público, bem como o procedimento e os limites materiais que deverão ser observados na criação de outras normas jurídicas". 393

Para Tércio Sampaio Ferraz Jr., "competência” seria uma forma de poder jurídico, isto é, de exercício impositivo de comportamentos em relação de autoridade, atribuído pelo estatuto da pessoa jurídica (pública ou privada) a seus órgãos. ${ }^{394}$

Enquanto poder jurídico, “competência” pode ser entendida especificamente como capacidade juridicamente estabelecida de assumir direitos e deveres e de realizar atos, criando normas (ou efeitos jurídicos) por meio (e de acordo) com certos enunciados.

Considerando-se como objeto da Ciência do Direito todas as normas jurídicas do sistema do direito positivo, podemos afirmar que, de um modo geral, todas visam a disciplinar as condutas intersubjetivas. No entanto, é possível relativizar tal classificação e dividir o conjunto de normas metodologicamente em dois grandes blocos; parte delas tem por objetivo regular condutas e o fazem por meio dos modais deônticos "permitido" (P), "proibido" (V) e “obrigatório" (O), que denominamos "regras de conduta", que visam à ordenação final da conduta como objetivo imediato.

As demais, paralelamente, visam a regular diretamente a produção de novas normas que ingressarão no ordenamento, assim como a sua retirada; a estas denominamos "regras de estrutura". São normas que aparecem como condição sintática para a elaboração de outras normas, instituindo condições, estabelecendo limites e a conduta a ser seguida para a produção de normas do primeiro tipo.

As normas que outorgam competência são tipicamente "regras de estrutura", assim como as relativas a isenções, procedimentos administrativos e judiciais,

393 GAMA, Tácio Lacerda, op. cit. (nota 18), p. 65.

${ }^{394}$ FERRAZ JR, Tércio Sampaio. Introdução ao Estudo do Direito, Atlas, 2008, São Paulo, pp. 129/130. 
visto que direcionadas aos sujeitos competentes para expedir normas, delimitam o processo de produção normativo.

Como observa Paulo de Barros Carvalho, não são apenas os entes políticos que estão submetidos às regras de estrutura relativas à competência, mas igualmente, por exemplo, o Presidente da República, os governadores e os prefeitos ao expedir decretos sobre qualquer tributo, os ministros e secretários de finanças ao editar as correspondentes instruções normativas; assim também os agentes da administração das três esferas encarregados de lavrar os atos dos lançamentos tributários. Até mesmo o particular que, por força de lei, está investido na condição de praticar o que a doutrina denomina de autolançamento, criando norma individual e concreta, também está revestido da competência tributária, dirigindo-se a todos as normas de estrutura relativas à competência. 395

Neste contexto normativo, Tácio Lacerda Gama classifica as competências em legislativas e infralegislativas. ${ }^{396}$ Estas compreendem as competências administrativa (lançamentos de ofício), jurisidicional (decisões do Poder Judiciário) e privada (autolançamento do particular); já a competência legislativa limita-se estritamente à capacidade de legislar sobre tributos, englobando a produção de leis ou atos normativos secundários.

Estabelecemos neste ponto um novo corte metodológico, delimitando nosso estudo à competência legislativa, tomando-a em termos tributários, enquanto autorizações concedidas pela Constituição às pessoas políticas de direito constitucional interno para legislar sobre matéria tributária. Trata-se, assim, de uma aptidão de que são dotadas estas pessoas para expedir regras jurídicas que irão inovar o ordenamento jurídico. Estas regras são aquelas normas gerais e abstratas que instituem tributos e criam deveres instrumentais e sanções tributárias.

É neste diapasão que Roque Carrazza entende "competência tributária" como a aptidão que possuem os entes federativos de criar tributos in abstrato. Ou seja, aquela faculdade que a Constituição Federal dá aos entes federativos de, com base em seus arquétipos, criar tributos. ${ }^{397}$

${ }^{395}$ CARVALHO, Paulo de Barros, op. cit. (nota 19), pp. 228/229.

${ }^{396}$ GAMA, Tácio Lacerda, op. cit. (nota 21), p. 266.

${ }^{397}$ Cf. CARRAZZA, Roque, A., op. cit. (nota 326), p. 491. 
Na lição de Paulo de Barros Carvalho, competência tributária é definida como "uma das parcelas entre as prerrogativas legiferantes das quais são portadoras as pessoas políticas, consubstanciada na faculdade de legislar para a produção de normas jurídicas sobre tributos", configurando tema eminentemente constitucional. Em outras palavras, competência tributária é a aptidão, atribuída pela Constituição Federal aos entes da Federação, para criar tributos, atribuindo-lhes autonomia financeira para gerar receitas, garantindo-lhes ingressos financeiros. ${ }^{398}$

\subsubsection{O Sistema Tributário: Delimitação das Competências}

Quando o constituinte dotou os entes federativos de fontes de recursos financeiros, atribuindo-lhes autonomia financeira, procedeu a uma minuciosa repartição dos critérios materiais dos impostos cabíveis a cada um dos entes políticos e introduziu um complexo de princípios que funciona como óbice, vedação ou limitação a esse poder de tributar, no intuito de construir um sistema livre de conflitos, atritos, dúvidas e problemas de atuação. ${ }^{399}$

Estes princípios, que "servem como diretrizes", conferem certeza e segurança às pretensões do Estado, preservando concomitantemente os direitos e garantias dos cidadãos. ${ }^{400}$ Conformam ainda o desenho constitucional das competências tributárias as normas imunizadoras, ou normas de competência negativa, que compõem, juntamente com os princípios e as regras de competências impositivas, a tríade que delimita a atuação do legislador infraconstitucional.

Tércio Sampaio Ferraz observa que são três as funções das imunidades no Sistema Tributário Nacional: (i) função de bloqueio (proíbe a instituição de tributos, sob pena de nulidade); (ii) função de resguardo (protege liberdades consideradas relevantes, como de pensamento, de expressão, de informar e de ser informado) e (iii) função programática (alcance de certos objetivos, de forma abrangente). ${ }^{401}$ De fato, não são todas as imunidades que se voltam à proteção de valores constitucionais, havendo algumas que

\footnotetext{
${ }^{398}$ Cf. CARVALHO, Paulo de Barros, op. cit. (nota 338), pp. 235/236.

${ }^{399}$ Cf. ATALIBA, Geraldo, op. cit. (nota 346), p. 34.

${ }^{400}$ Cf. CARVALHO, Paulo de Barros, op. cit. (nota 338), p.59.

401 Cf. FERRAZ, Tércio Sampaio, Livro Eletrônico e Imunidade Tributária. Revista dos Tribunais Cadernos de Tributário e Finanças Públicas. São Paulo: Revista dos Tribunais $\mathrm{n}^{\circ} 22$, janeiro-março de 1998, p.252.
} 
são estruturais, como as aplicadas às exportações ${ }^{402}$, que têm a função de instrumentos de política tributária ou econômica.

Neste sentido, Paulo Ayres Barreto leciona que o legislador constituinte ordinário brasileiro adotou como modelo estabelecer prescrições específicas, reduzindo o grau de abstração na aplicação do direito e definindo, desta forma, a atuação e o grau de liberdade do legislador infraconstitucional. ${ }^{403}$

De fato, no intuito de padronizar as normas do sistema tributário foi este o caminho definido pelo constituinte. Em diversas passagens do texto constitucional, atribuiu o legislador originário à lei complementar a tarefa de detalhar ou explicitar as competências ali delineadas, garantindo a almejada segurança jurídica ao sistema, mantendo sempre um vínculo de complementação e subordinação com a Constituição Federal, não permitindo modificações em suas diretrizes. No dizer de De Santi, deixar tal função a cargo dos legisladores infraconstitucionais representaria dar-lhes uma carta em branco, que poderia pôr em risco todo o sistema cuidadosamente esquadrinhado no campo constitucional. ${ }^{404}$

No artigo 146, a Constituição Federal atribuiu à lei complementar as funções ditas gerais, quais sejam: (i) dispor sobre conflitos de competência em matéria tributária entre a União, os Estados, o Distrito Federal e os Municípios; (ii) regular as limitações constitucionais ao poder de tributar e (iii) estabelecer normas gerais em matéria de legislação tributária. ${ }^{405}$

Esta atuação do legislador complementar está obrigatoriamente subordinada a todos os preceitos contidos no texto constitucional, em especial ao princípio federativo e à autonomia dos entes.

Portanto, não incumbe à lei complementar fixar limites à competência tributária, constituindo sua função integrar ou aperfeiçoar, como indica o próprio nome, aquelas normas estabelecidas pela Constituição Federal. Destarte, não lhe será permitido

${ }^{402}$ Como por exemplo, a prevista no art. $156, \S 3^{\circ}$, II, relativa ao ISS e art. 155 , XII, “e”, aplicável ao ICMS.

${ }^{403}$ Cf. BARRETO, Paulo Ayres, op. cit. (nota 135), p. 27.

${ }^{404}$ Cf. SANTI, Eurico Marcos Diniz, op. cit. (nota 366), pp. 328-329.

${ }^{405}$ Muito se discutiu sobre as funções atribuídas por esta norma à lei complementar. Tais entendimentos deram origem às denominadas correntes dicotômica e tricotômica. Para aquela, a terceira função, contida no inciso III, só seria aplicável para realizar as funções dispostas nos dois incisos anteriores, privilegiando a autonomia dos entes; para a tricotômica, a lei complementar possui efetivamente três funções sendo, destarte, superior hierarquicamente às leis ordinárias dos entes. Com a redação conferida pela atual CF, prevalece esta última corrente, segundo a qual, cabe à lei complementar as três funções, privilegiando, neste sentido, a segurança jurídica, sob o prisma da certeza. 
restringir ou alargar as competências da forma como definidas constitucionalmente. E, neste sentido, o importante é que tais normas gerais imponham o mesmo tratamento aos diversos entes, preservando desta forma o princípio federativo. Segundo De Santi, "a garantia do princípio federativo e da autonomia dos municípios está jungida à generalidade dos destinatários, realizando também ao primado da isonomia das pessoas políticas". 406

A CF atribui ainda à lei complementar, além das ditas funções gerais, outras específicas, relativas a vários tributos. Assim, por exemplo, traz disposições quanto aos empréstimos compulsórios, aos impostos de competência residual da União, ao Imposto sobre Transmissão Causa Mortes ou Doações - ITCMD, ao Imposto sobre a Circulação de Mercadorias e Serviços - ICMS, ao Imposto sobre Serviços - ISS e outras.

Impende ressaltar que, apesar da exigência constitucional de lei complementar e dos 22 anos passados de sua promulgação, algumas dessas leis ainda não foram editadas, como, por exemplo, a que dispõe sobre o ITCMD. No entanto, a eventual ausência da lei complementar, embora danosa ao sistema tributário, pelo fato de desfalcálo da necessária complementação sobre o tema, não tem o condão de inibir a produção normativa de instituição de tributos pelos entes federativos. Isto é: a inexistência da lei complementar não derroga a competência tributária dos entes tributantes, que advém da própria Constituição, uma vez que encontra fundamento diretamente no texto constitucional, sendo permitido ao ente tributante seu exercício, editando as normas gerais a ele necessárias.

Além disto, com base na interpretação sistemática da $\mathrm{CF}$, em especial do $\S 3^{\circ}$ do artigo 34 da ADTCi e $\S 3^{\circ}$ do art. 24 da CF/88, os Estados e o Distrito Federal podem exercer suas competências legislativas plenas, possuindo competência concorrente em matéria tributária. Desta forma, a inércia da União abre espaço para a legislação concorrente e legítima dos outros entes federativos.

Por fim, compõem ainda o sistema tributário brasileiro as regras de partilha de receitas, que determinam percentuais sobre a receita de determinados tributos, a serem repassados a outros membros da Federação. É que a nossa Carta Magna adotou um sistema complexo para alcançar o equilíbrio federativo, que inclui, além das competências positivas, dos princípios e das imunidades, também a repartição das receitas.

\footnotetext{
${ }^{406}$ SANTI, Eurico Marcos Diniz, op. cit. (nota 366), p. 329.
} 
Segundo Tércio Ferraz, nosso sistema tributário conjuga a outorga de competências tributárias exclusivas, por fonte, que indica o tributo, com o sistema de participação no produto da receita, pelo produto, que indica a repartição de receitas. ${ }^{407}$

Portanto, optou o constituinte originário por garantir a autonomia dos entes da Federação mediante ingressos derivados de um sistema misto de partilha de competência e de partilha do produto da arrecadação. ${ }^{408}$

\subsubsection{A discriminação das competências e a classificação dos tributos}

Nosso sistema tributário foi construído de forma a inexistir conflitos ou superposições de competências tributárias, constituindo um sistema cujas normas formam um complexo único. Neste sistema, atribuiu-se a cada um dos entes políticos a competência para instituir imposto sobre determinado critério material "distinto e identificável só consigo mesmo", constituindo instituto jurídico autônomo. No dizer de Amilcar Falcão, citado por Ataliba, "sendo rígida a nossa discriminação de rendas, daí resulta que cada uma das unidades federadas somente pode decretar tributos incluídos na sua competência". 409

Segundo Geraldo Ataliba, o legislador constitucional, tendo como objetivo obstar a bitributação, optou pela construção de um sistema "hirta e inflexivelmente ordenado, circunscrito, limitado e restrito", que se tornou peculiaridade do nosso sistema tributário. ${ }^{410}$

Para Schoueri, essa repartição constitucional de competências teve como finalidade garantir aos entes os ingressos financeiros suficientes para manter-lhes a independência, que é assegurada, sob outros aspectos, como vimos, pelo sistema federativo. $^{411}$

Os objetivos perquiridos pelo legislador originário na discriminação de competências impositivas eram obstar a bitributação jurídica, assegurar a autonomia

407 Cf. FERRAZ JÚNIOR, Tércio Sampaio, Direito Constitucional, - Liberdade de Fumar, Privacidade, Estado, Direitos Humanos e Outros Temas, São Paulo, Manole, 2007, pp.349.

${ }^{408}$ Cf. AMARO, Luciano, Direito Tributário Brasileiro, São Paulo, Saraiva, 14a ed., p.93.

${ }^{409}$ ATALIBA, Geraldo, op. cit. (nota 346), p. 26.

${ }^{410}$ Idem, ibidem, pp. 26/27.

411 SCHOUERI, Luis Eduardo, Discriminação de Competências e Competência Residual. In: Direito Tributário: Estudos em Homenagem a Brandão Machado, São Paulo, Dialética, 1998, pp. 82. 
financeira de todos os entes da federação e evitar conflitos entre eles ${ }^{412}$, que o levou a reparti-las de forma rígida, elevando o tema das espécies tributárias ao altiplano constitucional, visto que, para empreender a divisão de competência, o constituinte utilizou-se da classificação das espécies. Para tanto, definiu para cada uma destas espécies um regime jurídico próprio, que caso não seja seguido na instituição do tributo eivará de inconstitucionalidade a exação.

Geraldo Ataliba já havia assinalado a importância do tema e os efeitos prescritivos da inserção da classificação dos tributos no texto constitucional, reconhecendo que ao estabelecer espécies e subespécies, a Constituição Federal outorgou-lhes regimes jurídicos diferenciados, trazendo em seu próprio texto princípios e regras diferentes e peculiares aplicáveis a cada uma delas. ${ }^{413}$

Portanto, em nosso sistema jurídico, a classificação constitucional dos tributos tem como finalidades a repartição das competências e a indicação do regime jurídico a ser seguido por cada uma das espécies ali indicadas. Tércio Ferraz observa que o sistema tributário da forma como concebido, classificando os tributos de modo a permitir a partilha de competências, é o que organiza e estrutura a própria Federação. ${ }^{414}$

O essencial à forma federativa de Estado é a existência de fontes de recursos financeiros para os entes federativos, fontes estas que devem decorrer diretamente da Constituição. Por outras palavras, a divisão de rendas tributárias deve ser feita pelo próprio texto constitucional. Essa divisão, contudo, pode dar-se tanto por meio da atribuição de competências (rigidamente distintas, excludentes uma da outra, ou sobrepostas, isso não é relevante), por meio da repartição de receitas entre todos os entes, ou por um sistema híbrido, com a adoção de ambas as formas, como se dá no Brasil.

A Constituição, em seu artigo 145, dispõe sobre as espécies tributárias comuns a todos os entes políticos: impostos, taxas e contribuições de melhoria ${ }^{415}$ e relaciona minuciosamente, nos artigos 153 a 156, cada uma das materialidades dos impostos a serem instituídos pelas pessoas políticas, estipulando-as e outorgando-lhes a competência. Estas materialidades são complementadas pelas regras de imunidade,

${ }^{412}$ Cf. ATALIBA, Geraldo, op. cit. (nota 363), p. 24.

${ }^{413}$ Idem, Hipótese de Incidência Tributária, São Paulo, Revista dos Tribunais, 1978, p. 124.

${ }^{414}$ Cf. FERRAZ JÚNIOR, Tércio Sampaio, op. cit. (nota 407), pp.349.

${ }^{415}$ Alguns doutrinadores, representados por nomes como Paulo de Barros CARVALHO, entendem serem apenas estas as espécies tributárias e que tanto as contribuições, como os empréstimos compulsórios assumem ora a feição de imposto, ora de taxa, conforme definam seus critérios materiais. 
consideradas como competências negativas, já que limitam aquele campo de incidência definido para os entes, relativamente a determinadas pessoas (imunidade subjetiva), objetos, fatos ou situações (imunidade objetiva) ou aquelas que reúnem ambos (imunidade mista).

Relativamente às taxas e contribuições de melhoria, estas podem ser instituídas por qualquer das pessoas políticas internas, estando autorizadas a cobrar taxas na medida em que desempenhem a atividade que serve de pressuposto para sua exigência (poder de polícia ou utilização, efetiva ou potencial, de serviço público específico e divisível). O mesmo ocorre em relação à contribuição de melhoria, podendo instituí-la aquelas pessoas jurídicas de direito público que realizarem obra que gerar valorização imobiliária dos particulares.

Os empréstimos compulsórios, de competência exclusiva da União, constituem outra espécie autônoma de tributo, podendo ser instituídos somente nos casos previstos no artigo 148, incisos I e II da Constituição; isto é, (i) para atender a despesas extraordinárias, decorrentes de calamidade pública, de guerra externa ou sua iminência e (ii) no caso de investimento público de caráter urgente e de relevante interesse nacional. Qualquer uma das situações para introduzi-los exige o texto constitucional a edição de lei complementar.

A quinta e última espécie constitucional de tributo refere-se às contribuições, previstas no artigo 149, que se divide em sociais, de intervenção no domínio econômico e de interesse das categorias profissionais ou econômicas, todas de competência exclusiva da União, com exceção das contribuições para custeio da iluminação pública, cuja competência é exclusiva dos Municípios e do Distrito Federal, e das cobradas dos servidores públicos destinadas ao financiamento de seus sistemas de previdência e assistência social, que é instituída e cobrada por todas as pessoas jurídicas de direito público interno.

A classificação das contribuições em sociais, corporativas ou profissionais e interventivas decorre da finalidade constitucional prevista para que possam ser legitimamente criadas. Vejamos quais são essas finalidades: (i) contribuições sociais custear a seguridade social ou projetos sociais; (ii) contribuições corporativas ou profissionais - custear entidades que têm por objetivo fiscalizar e regular o exercício de determinadas atividades profissionais ou econômicas; e (iii) contribuições interventivas, 
que visam a ser um instrumento de atuação da União na área econômica, com a finalidade de regular a economia.

Além destas contribuições, há ainda aquelas sociais destinadas especificamente à seguridade, capituladas no artigo 195, que possuem regime jurídico próprio.

\subsubsection{Repartição de competências no direito comparado}

Aventar modificação na outorga de competências impositivas no Brasil traz subjacente a discussão da alteração da forma federativa de Estado (protegida por cláusula pétrea) e da quebra da autonomia dos entes políticos. Mas é possível afirmar que o fato de o Brasil ter adotado o Federalismo como forma de Estado não foi o motivo pelo qual o constituinte optou por proceder ao que denominamos "atribuição de competências impositivas" e à classificação dos tributos em espécies e subespécies.

Em outras palavras, ao contrário do que muitos acreditam, a rígida discriminação de competências não é requisito essencial dos sistemas federativos, como o é, por exemplo, a garantia da autonomia financeira de seus entes. ${ }^{416}$

De maneira geral, nos países que optam pela forma federativa de Estado $^{417}$, a competência tributária é definida em termos genéricos, caracterizando estes sistemas como flexíveis. ${ }^{418}$ Segundo Ataliba, desta flexibilidade do sistema constitucional decorre a flexibilidade do sistema tributário, da mesma forma que da inflexibilidade do sistema constitucional brasileiro decorre a inflexibilidade de nosso sistema tributário.

A federação norte-americana adotou um modelo constitucional flexível, atribuindo ao legislador ordinário, assim como às constituições e legislaturas estaduais, amplos poderes para multiplicar os tributos, partilhá-los, desmembrá-los ou extingui-los, não havendo qualquer obstáculo jurídico à pluritributação, o que leva os contribuintes a

${ }^{416}$ Cf. SCHOUERI, Luis Eduardo, op. cit. (nota 411), p. 83.

${ }^{417}$ É possível classificar o Estado sob os mais variados critérios. A classificação que toma como critério o modo pelo qual o poder é distribuído dentro do Estado possui duas espécies: simples ou composto. Os Estados simples, ou Unitários, possuem apenas um órgão de governo político, invariavelmente central. São exemplos deste tipo de Estado a França, Espanha, Itália e Portugal e, à exceção do Brasil, todos os demais países latino-americanos. Já o Estado composto envolve a união de duas ou mais entidades políticas e pode ser de quatro diferentes espécies: união pessoal, união real, confederação e federação. Cf. ZIMMERMANN, Augusto, op. cit. (nota 327), p. 13.

${ }^{418}$ Cf. ATALIBA, Geraldo, op. cit. (nota 346), p. 27. 
arcar com o fardo da dupla tributação e o tempo agregado, além do custo de pagar impostos duplicados. ${ }^{419}$

Nosso sistema de repartição de competências tem sido alvo de elogios da doutrina alienígena há muito tempo. Geraldo Ataliba, confrontando nossa Constituição Federal de 1946 e os sistemas constitucionais tributários de outros países à época, entendeu ser o nosso "mais perfeito juridicamente", com características sui generis e considerado por Carvalho Pinto como "verdadeira conquista da ciência do direito constitucional pátrio". 420

De fato, tal característica é particular e específica do nosso sistema tributário. No direito comparado, buscamos a experiência da República portuguesa, cuja forma de Estado é o Unitário, em que os “entes menores" e o Governo recebem, por concessões da Assembleia da República, autorizações legislativas em matéria tributária, "sujeitas a certos pressupostos e limites" (n. 2 a 5 do art. 165 da CP). ${ }^{421} 422$ Isto porque a Constituição Portuguesa concedeu competência exclusiva na área tributária à Assembleia da República, seja para a criação de impostos, regime geral das taxas e demais contribuições, enumerando no item um do artigo 165 as matérias sobre as quais versa tal competência. Convém ressaltar que, num estado unitário, é normal a ausência da discriminação das competências impositivas, pois não há razão para tal, já que o poder se concentra em um único ente.

Muitos Estados Unitários tornaram-se Federais em função do êxito da fórmula conciliatória, tendo eles procedido à sua descentralização política graças à vontade política ou necessidade de maior eficiência. É o caso do Brasil, cujo Estado Unitário foi

${ }^{419}$ Cf. ATALIBA, Geraldo, op. cit. (nota 346), p. 71.

${ }^{420}$ Cf. Idem, ibidem, p. 28.

${ }^{421}$ CAMPOS, Diogo Leite de e CAMPOS, Monica Horta Neves, Direito Tributário, Coimbra, Del Rey, $2^{\mathrm{a}}$. ed., 2001, p. 197.

${ }^{422}$ CP, art. 165. [...] "2. As leis de autorização legislativa devem definir o objecto, o sentido, a extensão e a duração da autorização, a qual pode ser prorrogada.

3. As autorizações legislativas não podem ser utilizadas mais de uma vez, sem prejuízo da sua execução parcelada.

4. As autorizações caducam com a demissão do Governo a que tiverem sido concedidas, com o termo da legislatura ou com a dissolução da Assembleia da República.

5. As autorizações concedidas ao Governo na lei do Orçamento observam o disposto no presente artigo e, quando incidam sobre matéria fiscal, só caducam no termo do ano económico a que respeitam". Disponível em: <http://www.parlamento.pt/Legislacao/Paginas/ConstituicaoRepublicaPortuguesa.aspx >. Acesso em 19 de agosto de 2011. 
descentralizado "até certo ponto pela dimensão territorial e pelas diferenças regionais e culturais". ${ }^{423}$

\subsubsection{A Repartição dos Tributos sobre o Consumo na Federação Brasileira: a Origem do ISS}

Já vimos que a rigidez na repartição de competências tributárias impositivas foi opção do nosso constituinte, sem paralelo em outras Constituições no mundo. Ademais, esta discriminação de competência não é requisito essencial do sistema federalista, como o é, por exemplo, a autonomia dos entes federativos.

$\mathrm{Na}$ prática, contudo, esta inflexibilidade de nosso sistema mostra-se insuficiente para solucionar determinadas situações que se encontram nas denominadas "regiões de penumbra", que surgem em função de o legislador constituinte originário não ter esgotado com precisão os limites das fronteiras entre algumas competências impositivas. ${ }^{424}$ Isto ocorre especialmente em relação àqueles impostos sobre consumo, cuja competência foi rateada entre as três ordens: União (Imposto sobre Produtos Industrializados - IPI), Estados (Imposto sobre a Circulação de Mercadorias e Serviços de Transporte Interestadual, Intermunicipal e de Comunicação - ICMS) e Municípios (Imposto Sobre Serviços de Qualquer Natureza - ISS).

Relativamente ao ISS e ao ICMS (à época ainda ICM), o problema tem origem na própria ascendência dos tributos, que "nasceram" inspirados em um imposto sobre o consumo, o IVA - Imposto de Valor Agregado, instituído no âmbito da Comunidade Econômica Europeia - CEE. Sucessor dos antigos impostos sobre as vendas, que, em geral, oneravam cumulativamente cada fase econômica, o IVA surgiu em 1962 como solução para harmonizar as legislações tributárias dos países-membros (Alemanha, Bélgica, França, Holanda, Itália e Luxemburgo). ${ }^{425}$

Os contornos definitivos do tributo foram traçados por diretrizes emitidas por uma Comissão constituída com a missão específica de examinar as disparidades nas

\footnotetext{
${ }^{423}$ Cf. ZIMMERMANN, Augusto, op. cit. (nota 327), pp. 54-55.

${ }^{424}$ Cf. MACEDO, Alberto, ISS e IPI - A Lei Complementar e o Redesenho das Fronteiras Competenciais, In: Paulo de Barros Carvalho; Priscila de Souza. (Org.). VI Congresso Nacional de Estudos Tributários - Sist. Tributário Brasileiro e a Crise Atual, São Paulo, Noeses, 2009, v. VI, p. 2.

${ }^{425}$ Cf. MORAES, Bernardo Ribeiro, Doutrina e Prática do Imposto sobre Serviços, $1^{\mathrm{a}}$ ed, $3^{\mathrm{a}}$ tiragem, São Paulo, Ed. Revista dos Tribunais, 1984, pp. 20-22.
} 
estruturas fiscais dos países-membros, propondo medidas para eliminá-las. ${ }^{426}$ Neste sentido, o imposto vinha com o intuito de neutralizar a competição entre os países da comunidade, considerada condição prévia para a harmonização das legislações. Compunham seu critério material "as transmissões de bens e as prestações de serviços, efetuadas a título oneroso", inclusive as importações de bens. ${ }^{427}$

A expressão "transmissão de bens", para efeitos de incidência do imposto, vinha definida no artigo $5^{\circ}$ do mencionado diploma legal como "a transferência do poder de disposição de um bem material como proprietário", abarcando ainda, por expressa disposição legal, outros tipos de transmissão como, por exemplo, a incorporação de um bem móvel a um bem imóvel. Já a definição de "prestação de serviços" era feita por exclusão à definição anterior, abrangendo então, de forma ampla, "toda operação que não constitua transmissão de um bem no sentido do art. $5^{\circ}$. ${ }^{428}$ De modo geral, o imposto onerava tanto as vendas de bens materiais (mercadorias ou produtos) como de bens imateriais (serviços).

Desta forma, o conceito de "prestação de serviços" para fins de incidência daquele imposto não guardava qualquer relação com aquele adotado pelo direito civil, que consistia em simples fornecimento de trabalho. E para que ficasse clara tal abrangência, havia uma lista anexa à diretriz que esclarecia, com uma definição denotativa ${ }^{429}$ de "prestação de serviços", que elencava, entre outras, a "cessão de um bem imaterial", a "execução de trabalho relacionado com um bem material" (desde que não constitua transmissão do bem). ${ }^{430}$

Ainda que a CEE tenha anunciado que o conceito tributário de "prestação de serviços" era equivalente àquele do direito civil, Bernardo Ribeiro de Moraes entende que seu campo de abrangência equivalia aos "serviços de qualquer natureza", que englobaria a venda de bens imateriais, como cessão de direitos, transporte, armazenagem e, inclusive, o fornecimento de trabalho. ${ }^{431}$

426 A Comissão ficou conhecida como Neumark, nome de seu presidente, Prof. Fritz Neumark, e era integrada por estudiosos de renome de vários países, incluindo um representante da Universidade de Colúmbia. Cf. MORAES, Bernardo Ribeiro, op. cit. (nota 425), p. 21.

${ }^{427}$ Cf. Idem, ibidem, p. 23.

${ }^{428}$ Cf. MORAES, Bernardo Ribeiro, op. cit. (nota 425), p. 23.

${ }^{429}$ As definições e suas classificações serão tratadas no item 5.3.1 deste trabalho.

${ }^{430}$ Cf. MORAES, Bernardo Ribeiro, op. cit. (nota 425), p. 24.

${ }^{431}$ Cf. Idem, ibidem, p. 25. 
$\mathrm{O}$ autor, em exaustivo estudo sobre o assunto, relata a experiência de vários países, inclusive alguns não membros da $\mathrm{CEE}$, que adotaram o imposto, analisando em especial a abrangência aplicada à expressão "prestação de serviços". De maneira geral, os países catalogaram o que deveria ser considerado como "serviço" para fins de incidência do imposto, ou adotaram a definição formulada pela CEE.

Na França, o campo dos serviços veio expresso por meio da enumeração de diversas atividades, que levam a uma ideia de "prestação de serviços" em sentido estrito como "venda de bens imateriais", já que, nos termos da referida lei, prestadores de serviço seriam as pessoas que vendem bens incorpóreos. Segundo a doutrina francesa, estavam assim sujeitos ao imposto os locadores de coisas (por exemplo, de bens materiais, muro para propaganda), os vendedores de coleções, os que forneciam trabalho em bens de terceiros, entre outros. ${ }^{432}$

$\mathrm{Na}$ Alemanha, o imposto sobre o valor agregado foi adotado somente em 1968, incidindo de maneira ampla sobre a "transmissão de bens e a prestação de serviços", definindo as expressões na forma como definido pela CEE. A Itália adotou lei similar em 1971, com base na sistemática europeia, definindo, no entanto, "prestação de serviço" como toda operação diversa da transferência de bens, incluindo as cessões de patentes, marcas e de direitos, armazenagem de bens, transporte, publicidade, locação de bens móveis e imóveis, etc. ${ }^{433}$

No entender de Bernardo Ribeiro de Moraes, o imposto sobre o valor agregado adotou o conceito econômico de "prestação de serviço", "assim entendido o bem econômico (meio idôneo para satisfazer uma necessidade) que não seja material, isto é, que não seja de extensão corpórea ou de permanência no espaço. Serviço, no sentido econômico, é sinônimo de bem imaterial, fruto do esforço humano aplicado à produção" (g.n.). ${ }^{434}$

Neste sentido, "serviço" seria um bem imaterial que resultaria de uma atividade humana, englobando a atividade do transportador, do locador de bens móveis, do médico. Ou seja, como o conceito de serviço é extraído por exclusão da transmissão de bens materiais e o imposto sobre o valor agregado onera toda a cadeia produtiva, inclui-se

\footnotetext{
${ }^{432}$ Cf. MORAES, Bernardo Ribeiro, op. cit. (nota 425), p. 30.

${ }^{433}$ Cf Idem, ibidem, p. 39.

${ }^{434}$ Idem, ibidem, p. 41.
} 
nele tanto o fornecimento de trabalho em si (prestação de trabalho no direito civil), quanto outras atividades como a locação de bens móveis, cessão de direitos, entre outras.

No Brasil, antes do advento do ISS, seu campo de incidência, de maneira total ou parcial, era alcançado por três impostos: (i) imposto sobre transações, de competência dos Estados, que incidia sobre as hospedagens, locação de bens móveis, construção civil, etc.; (ii) imposto de indústria e profissões - IIP, municipal, cujo critério material era o exercício de atividade lucrativa, inclusive a prestação de serviços; e (iii) imposto de diversões públicas, instituído no âmbito dos Municípios, que incidia sobre jogos e diversões públicas.

Para alguns doutrinadores, como Roberto Barcellos de Magalhães, Eurico de Andrade Azevedo e Aliomar Baleeiro, o ISS não teria sido criado como um imposto novo em 1965, tratando-se, na verdade, do velho imposto sobre indústrias e profissões com nova denominação. Segundo Baleeiro, o ISS "reflete a sua anterior conceituação de impostos sobre profissões e indústria, uma das quais é a de quem alugar veículos, tratores, máquinas, roupas e chapéus de rigor, instrumentos e, em geral, móveis, como meio de vida ou habitual atividade remuneradora". 435

Mas esta não é a posição da doutrina majoritária, representada, entre outros, por Fábio Fanucchi, Antonio Roberto Sampaio Dória, José Afonso da Silva, Manoel Lourenço dos Santos e o próprio Bernardo Ribeiro de Moraes, para quem o ISS não substituiu o antigo IIP. Tratar-se-ia de "um imposto novo que ingressou no elenco dos tributos integrantes de nosso sistema tributário com a Emenda Constitucional $\mathrm{n}^{\circ} 18$, de 01.12.1965". ${ }^{436}$

Fato é que na reforma tributária de 1965, promovida pelo novo governo militar empossado após o golpe de 1964, o imposto fazia parte de um plano global de ação que se fundamentava numa nova ordem econômica que, por sua vez, exigia uma nova ordenação jurídica, em especial no campo tributário. ${ }^{437} \mathrm{O}$ membro norte-americano da comissão que criou o IVA no âmbito da CEE, professor Carl Shoup, veio ao Brasil a convite do governo para examinar o sistema tributário então vigente, tendo este concluído pela necessidade da adoção da tributação do valor agregado em substituição ao imposto sobre venda cumulativo.

435 BALEEIRO, Aliomar, Direito Tributário Brasileiro, 10ª ed., Rio de Janeiro, Forense, 1984, p.292-293.

${ }^{436}$ MORAES, Bernardo Ribeiro, op. cit. (nota 425), p. 61.

${ }^{437}$ Cf. Idem, ibidem, p. 46. 
Foi então que se criou a Comissão Especial de Reforma, com a tarefa de elaborar um projeto de reforma tributária, que contava com juristas e técnicos do jaez de Luis Simões Lopes, Rubens Gomes de Sousa, Gilberto de Ulhoa Canto, entre outros. Segundo Aires Barreto, a produção literária europeia impressionou nossos juristas, inclusive Aliomar Baleeiro, que à época era deputado federal, e "entusiasmados, todos resolveram imitar esse sistema, no Brasil, adotando o então ICM (hoje ICMS) e o ISS". 438

Deste modo, na reforma tributária de 1965, por meio da Emenda Constitucional $\mathrm{n}^{\mathrm{o}} 18$ de $1^{\mathrm{o}}$ de dezembro de 1965 , no capítulo destinado aos "impostos sobre a produção e a circulação", foi criado o Imposto sobre Serviços - ISS, outorgando a competência para sua instituição aos Municípios e atribuindo-se o então Imposto sobre a Circulação de Mercadorias - ICM aos Estados. 439

Segundo Aires Barreto, com a empolgação, os juristas "se esqueceram de olhar para a própria Constituição" ${ }^{440}$ e acabaram por violar o princípio da Autonomia Municipal, vários princípios constitucionais fundamentais e a própria sistemática do ISS, ao atribuir à lei complementar a definição dos serviços incluídos na competência municipal. É que os Estados para os quais foi concebido o modelo do IVA, e que formavam a CEE à época, estavam organizados em Estados Unitários, centrais, à exceção da Alemanha, que ainda que estivesse estruturada numa Federação, em muito se distinguia da nossa.

É certo que a autonomia concedida aos Municípios por nossa Constituição não encontrava parâmetros em nenhum daqueles países, todos Estados Unitários e, mesmo na Federação alemã, "o exercício de certa competência pelo governo central 'corta' a 'competência' municipal". ${ }^{441}$

Para Aires Barreto, o doutrinador brasileiro equivocou-se ao comparar estruturas absolutamente distintas, em prejuízo dos Municípios, que tiveram sua

\footnotetext{
${ }^{438}$ BARRETO, Aires, ISS na Constituição e na Lei, $3^{\mathrm{a}}$. ed., São Paulo, Dialética, p. 106.

439 “Art. 12. Compete aos Estados o impôsto sôbre operações relativas à circulação de mercadorias, realizadas por comerciantes, industriais e produtores./ Art. 15. Compete aos Municípios o impôsto sôbre serviços de qualquer natureza, não compreendidos na competência tributária da União e dos Estados. Parágrafo Único. Lei Complementar estabelecerá critérios para distinguir as atividades a que se refere este artigo das previstas no art. 12". Disponível em: <http://www2.camara.gov.br/legin/fed/emecon/19601969/emendaconstitucional-18-1-dezembro-1965-363966-publicacaooriginal-1-pl.html>. Acesso em 25 de abril de 2011

${ }^{440}$ BARRETO, Aires, op. cit. (nota 438), p. 106.

${ }^{441}$ Idem, ibidem, p. 106.
} 
competência tolhida com o modelo proposto. ${ }^{442}$ E mais, se a instituição e arrecadação dos tributos outorgada aos Municípios constituem instrumentos de sua própria autonomia, não é possível compatibilizar tal preceito à exigência de que lei complementar venha a definir os exatos termos desta competência. E conclui que "não é isto o que está dito na Constituição"443 e, entre as funções atribuídas à lei complementar pelo próprio texto constitucional, não está aquela de criar tributos.

$\mathrm{Na}$ visão de Bernardo Ribeiro de Moraes, "o fato de o legislador ter criado dois impostos, pouco importa". ${ }^{444}$ No entanto, ao desdobrar o IVA em dois tributos, um onerando a circulação de mercadorias (bens materiais) e outro a venda de bens não considerados mercadorias (serviços), exigiu a edição de diversos atos normativos para delimitar o campo de incidência de cada um deles, que já nasceram intimamente ligados no próprio texto da Constituição, fato comprovado pelo parágrafo único do artigo 15, que delegava à lei complementar a tarefa de distinguir as atividades que estariam submetidas à tributação de cada um dos dois impostos.

Logo após a promulgação da Emenda Constitucional $n^{\circ} 18$, foi editada a Lei $\mathrm{n}^{\circ} 5.172$ de 25.10.1966, posteriormente denominada Código Tributário Nacional CTN, dispondo nos artigos 71 e seguintes o critério material do ISS, listando as atividades consideradas "serviço" para fins de incidência do imposto, definindo seus contribuintes e a base de cálculo. Em janeiro de 1967, menos de três meses depois, foi editado o Ato Complementar $n^{\circ} 34$, que introduziu inovações na tributação dos serviços, inserindo no ordenamento o conceito de "atividade mista" ${ }^{445}$, ampliando o campo de incidência do ISS, para alcançar, entre outras, a locação de bens móveis e transferindo para a tributação pelo ICM o fornecimento de alimentação, bebidas e outras mercadorias nos restaurantes, bares, cafés e estabelecimentos similares.

Na Constituição Federal de 1967, foi alterada, na redação do artigo que outorgava a competência do ISS aos Municípios, a tarefa da lei complementar em relação ao imposto; doravante, caberia à lei complementar "definir" os serviços de qualquer

${ }^{442}$ BARRETO, Aires, op. cit. (nota 438), p. 107.

${ }^{443}$ Idem, ibidem, p. 107.

${ }^{444}$ MORAES, Bernardo Ribeiro, op. cit. (nota 425), p. 55.

445 Alteração $8^{\circ}$ do Ato Complementar que deu nova redação do $\S 2^{\circ}$ do art. 71 da Lei $n^{\circ} 5.172$, que introduziu o conceito de atividade mista: "Os serviços a que se refere o inciso IV do parágrafo anterior, quando acompanhados do fornecimento de mercadorias, serão considerados de caráter misto, para efeito de aplicação do disposto no $\S 3^{\circ}$ do art. 53 , salvo se a prestação de serviço constituir seu objeto essencial e contribuir com mais de $75 \%$ (setenta e cinco por cento) da receita média mensal da atividade." 
natureza alcançados pelo ISS, e não mais estabelecer critérios para distinguir as atividades sujeitas à tributação do ICM e do ISS, como definido na Emenda Constitucional no $18 .{ }^{446}$

Para cumprir tal tarefa, foi então editado o Decreto-lei $\mathrm{n}^{\circ} 406$ de 31.12.1968, que revogou expressamente todas as disposições do CTN relativamente aos dois tributos, assim como as modificações posteriores, passando a regulamentar toda a tributação dos dois impostos e trazendo critérios relativos à incidência do ISS e ICM. Entre outras modificações, foi suprimida a atividade considerada legalmente mista, de forma que estariam submetidos à tributação do ISS exclusivamente aqueles serviços incluídos na lista anexa, ainda que envolvessem fornecimento de mercadoria. Por outro lado, ficaram sujeitas à incidência do ICM aquelas atividades não definidas na lista que envolvesse fornecimento de mercadoria ${ }^{447}$.

Mas tal regulamentação não teve o condão de pacificar por definitivo as dúvidas em relação à tributação do ISS e, em função das incertezas surgidas sobre o campo de incidência do tributo, foi editado, apenas oito meses depois, o Decreto-lei $\mathrm{n}^{\circ} 834$, de 8.9.1969, que estabelecia "normas gerais sobre conflito de competência tributária, sobre o Imposto de Serviços", e trazia na lista anexa 66 itens, em substituição aos 29 itens listados pelo Decreto-lei no $406 .{ }^{448}$ Ainda no mesmo ano, veio outro Decreto-lei, o de $n^{\circ} 932$ de 10 de outubro, trazendo disposições relativas aos dois impostos e solucionando questões relativas à primeira lista de serviços.

A Emenda Constitucional $n^{\circ} 1$ de 1969, assim como a Constituição Federal de 1988 mantiveram a redação adotada pela Constituição Federal de 1967 relativa à competência municipal do ISS, concedendo à lei complementar, especificamente em relação ao imposto, a tarefa de definir os serviços sujeitos à sua incidência. Sucedeu o Decreto-lei $n^{\circ} 406 / 68$ a Lei Complementar $n^{\circ} 116$, de 31.07.2003 que, no entanto, não revogou por completo aquele diploma legal, estando ainda vigentes alguns de seus dispositivos, em especial aquele que regulamenta o regime tributário diferenciado aludido pelo art. $9^{\circ}, \S 3^{\circ}$, relativo às Sociedades Uniprofissionais.

446 Art 25 da CF 67 - "Compete aos Municípios decretar impostos sobre: [...] II - serviços de qualquer natureza não compreendidos na competência tributária da União ou dos Estados, definidos em lei complementar".

${ }^{447}$ Conforme teor dos parágrafos $1^{\circ}$ e $2^{\circ}$ do art. $8^{\circ}$ do DL 406/68: " $§ 1^{\circ}$ Os serviços incluídos na lista ficam sujeitos ao imposto previsto neste artigo, ainda que sua prestação envolva fornecimento de mercadorias. $\S$ $2^{\circ} \mathrm{O}$ fornecimento de mercadorias com prestação de serviços não especificados na lista fica sujeito ao Imposto sobre Circulação de Mercadorias".

${ }^{448}$ Cf. MORAES, Bernardo Ribeiro, op. cit. (nota 425), pp. 59-67. 
Mas a Constituição Federal de 1988, ao delegar aos Estados a competência para tributar "operações relativas à circulação de mercadorias e sobre prestações de serviços de transporte interestadual e intermunicipal e de comunicação, ainda que as operações e as prestações se iniciem no exterior”, e aos Municípios a competência sobre "serviços de qualquer natureza, não compreendidos no art. 155, II, definidos em lei complementar", estabeleceu, em alguns dispositivos, critérios para eventuais sobreposições entre estas competências.

Desta forma, o inciso IX, "b" do $\S 2^{\circ}$ do artigo 155 da CF 88, dispõe que incidirá o ICMS sobre o valor total da operação, quando mercadorias forem fornecidas com serviços não compreendidos na competência tributária dos Municípios, de maneira similar ao que dispunha o Decreto-lei no 406/68.

Segundo o Supremo Tribunal Federal - STF, a delimitação dos campos de competência tributária entre Municípios e Estados decorre do sistema normativo específico, que inclui, além da Constituição Federal (art. 155, II, § $2^{\circ}$, IX, b e 156, III da CF), a Lei Complementar $n^{\circ} 87 / 96$ (art. $2^{\circ}$, IV, da LC 87 /96) e a Lei Complementar $n^{\circ}$ 116/03 (art. $1^{\circ}, \S 2^{\circ}$, da LC $116 / 03$ ), sendo possível extrair destas normas os seguintes critérios: (i) sobre as operações de circulação de mercadoria e sobre os serviços de transporte interestadual e internacional e de comunicação incide ICMS; (ii) sobre operações de prestação de serviços compreendidos na lista de que trata a LC 116/03 (que sucedeu o DL 406/68) incide ISSQN; e (iii) sobre operações mistas, assim entendidas as que agregam mercadorias e serviços, incide ISSQN sempre que o serviço agregado estiver compreendido na lista de que trata a LC 116/03 e incide ICMS sempre que o serviço agregado não estiver previsto na referida lista. ${ }^{449}$

\subsubsection{Constituição Federal: Tipos ou Conceitos?}

Apesar da rigidez na repartição das pretensões impositivas entre os entes imposta no âmbito constitucional, a matéria da discriminação de competências também suscita a controvérsia da dicotomia tipo-conceito, que "é ínsita a qualquer ramo

\footnotetext{
${ }^{449}$ Trecho do acórdão do RE 732.496/RS, Relator Min. Teori Albino Zavascki.
} 
didaticamente autônomo do direito" ${ }^{450}$, relativamente àqueles signos de que se utilizou o constituinte nesta tarefa.

De modo geral, o "tipo" se estrutura em formas flexíveis e fluidas, contrapondo-se ao "conceito" que se traduz por definições exatas. Adverte Schoueri que "o objeto visado pela norma é único, mas a norma, por implicar abstração, a ele se referirá usando um tipo ou um conceito", concluindo que ambos devem ser entendidos "como formas de que se vale o direito para captar uma mesma realidade." ${ }^{451}$

No entanto, considerando-se que conceito limita, seleciona, tem-se que quanto maior for a abstração em sua fixação, maior se tornará sua abrangência, já que abrigará um maior número de propriedade ou objetos, sendo, no entanto, no sentido inverso e proporcional, mais vazio de conteúdo e significado. ${ }^{452}$

Misabel Derzi analisa os traços distintivos destas duas formas de pensamento. Segundo a mestra, os "conceitos fechados"

se caracterizam por denotar o objeto através de notas irrenunciáveis, fixas e rígidas, determinantes de uma forma de pensar seccionadora da realidade, para a qual é básica a relação de exclusão ou.....ou. Através dessa relação, calcada na regra de identidade, empreendem-se classificações com separação rigorosa entre as espécies. ${ }^{453}$

Por outro lado, os "tipos" identificam-se por estabelecer

notas referenciais aos objetos, porém renunciáveis, que se articulam em uma estrutura aberta à realidade, flexível, gradual, cujo sentido decorre dessa totalidade. Nele, os objetos não se subsumem mas se ordenam segundo método comparativo que gradua as formas mistas ou transitivas. ${ }^{454}$

Adotar uma ou outra forma de pensamento implica, por vias oblíquas, em ampliar ou reduzir a tarefa do legislador infraconstitucional relativamente às competências tributárias. É que resultando os conceitos exclusivamente da exegese do texto constitucional, esta opção do constituinte em demarcar as competências significa uma fixação, um congelamento das situações ali estatuídas.

${ }^{450}$ BARRETO, Paulo Ayres, Elisão Tributária - Limites Normativos, Usp, São Paulo, 2008, p. 67.

${ }^{451}$ SCHOUERI, Luis Eduardo, op. cit. (nota 411), p. 112.

${ }^{452}$ Cf. DERZI, Misabel de Abreu, Direito Tributário, Direito Penal e Tipo, São Paulo, Ed. Revista dos Tribunais, $2^{\mathrm{a}}$. ed., 2007, p. 114.

453 Idem, ibidem, p. 114.

${ }^{454}$ Idem, ibidem, p. 114. 
Por outro lado, adotando-se um pensamento tipológico, significa admitir que o papel de narrar minuciosamente a complementação da outorga de competência seria da lei complementar, que lhe daria então os contornos definitivos. E mais, significa admitir uma evolução nos limites de sua descrição, inerente aos tipos, cujas características típicas podem ir se sucedendo, alternando-se, substituindo-se ou até mesmo eliminando uma às outras, já que o conjunto dos tipos é "um sistema em movimento". 455

Subjacente à discussão sobre a utilização de "tipos" ou "conceitos fechados" nos signos que definem a competência impositiva dos entes opõem-se valores jurídicos, representados pelos princípios que privilegia o intérprete. ${ }^{456}$

Paulo de Barros Carvalho leciona que, ainda que todo e qualquer princípio se refira de maneira direta ou indireta a valores, eles podem assumir duas funções distintas no ordenamento: (i) limites objetivos e (ii) valores propriamente ditos, ${ }^{457}$ sendo que é o grau de objetividade de suas proposições que os diferencia. Quando os princípios assumem a feição de "valor" tendem a uma graduação hierárquica; quando assumem "limites objetivos" há critérios definidos que delimitam seu conteúdo, permitindo saber objetivamente quando um limite foi excedido e quando foi observado.

Neste sentido, a utilização pelo legislador constituinte de "tipos" coaduna-se mais perfeitamente com os princípios valores como o da igualdade, o da justiça e contempla as próprias mutações sociais. Por outro lado, defender a utilização de “conceitos fechados" privilegia princípios limites como a segurança jurídica, a legalidade e a uniformidade. ${ }^{458}$ Apesar de a segurança jurídica ser apontada, de maneira geral ${ }^{459}$, como um princípio que denota valor, neste contexto ela representa um limite rígido e objetivo à atuação do legislador infraconstitucional, já que pressupõe a definição completa dos conceitos no texto constitucional, de maneira uniforme e geral.

Adverte Misabel Derzi que, entre as posturas que defendem a utilização de "tipos" ou de "conceitos fechados", existe "uma série infinita de transições intermediárias"; 460 Paulo A. Barreto, debruçando-se sobre o assunto, deparou-se na doutrina e jurisprudência com quatro percepções distintas. Alguns doutrinadores entendem

455 Cf. SCHOUERI, Luis Eduardo, Normas Tributárias Indutoras e Intervenção Econômica, São Paulo, Forense, 2005, p. 245.

${ }^{456}$ Cf. DERZI, Misabel de Abreu, op. cit. (nota 452), p. 113.

${ }^{457}$ CARVALHO, Paulo de Barros, op. cit. (nota 19), p. 257.

${ }^{458}$ Cf. DERZI, Misabel de Abreu, op. cit. (nota 452), p. 114.

${ }^{459}$ Entre eles, GAMA, Tácio Lacerda, op. cit. (nota 18), p.143.

${ }^{460}$ DERZI, Misabel de Abreu, op. cit. (nota 452), p. 114. 
que atribuir significação aos signos insertos no texto constitucional é tarefa exclusiva do legislador infraconstitucional. Já para outros, a participação deste legislador deve-se à vaguidade e imprecisão dos signos referidos na $\mathrm{CF}$, de modo que esta participação na construção do sentido é atividade meramente complementar. ${ }^{461}$

A terceira corrente defende que a Constituição Federal teria se utilizado de "tipos" na descrição das competências, cabendo ao legislador infraconstitucional conceituar os impostos nela estipulados. Neste sentido, a lição de Luis Eduardo Schoueri que, estudando as competências delineadas na Constituição para os impostos, constatou que:

[...] ali não se encontram parâmetros definitivos para a conclusão quanto ao aspecto material de cada imposto. As expressões empregadas pelo constituinte são meros nomes dados a impostos historicamente já existentes. Por isso, afirmamos que o constituinte não conceituou os impostos pertencentes a cada esfera tributante; apenas nominou-os contemplando um todo. Valendo-se das lições da teoria geral do direito, concluímos que o constituinte apenas contemplou a realidade a partir de tipos. ${ }^{462}$

Assim, para o referido autor, o constituinte apenas contemplou a realidade a partir de tipos jurídicos, que são elásticos e abertos, e não de conceitos, relegando assim à lei complementar a tarefa de complementar e delimitar aqueles parâmetros. $^{463}$

Finalmente, há aqueles que pregam que os conceitos constitucionais devem ser construídos por um processo de interpretação exclusivamente no campo constitucional, não podendo o legislador infraconstitucional afastar-se de tais balizas definidas no texto da Constituição. Teria assim nossa Carta Magna fixado conceitos quando repartiu as pretensões impositivas aos entes da federação. ${ }^{464}$ Esta a lição de Roque Carrazza, para quem todos os critérios da regra-matriz de incidência dos tributos podem ser extraídos do texto constitucional, não havendo, portanto, no papel do legislador infraconstitucional, qualquer margem de discricionariedade. ${ }^{465}$

Paulo Ayres Barreto compartilha da opinião de que constam da Constituição conceitos postos ou pressupostos, mitigando as duas posições anteriores,

\footnotetext{
${ }^{461}$ Cf. BARRETO, Paulo Ayres, op. cit. (nota 450), pp. 68-69.

${ }^{462}$ SCHOUERI, Luis Eduardo, op. cit. (nota 411), p. 112.

${ }^{463}$ Cf. Idem, op. cit. (nota 455), p. 236.

${ }^{464}$ Cf. BARRETO, Paulo Ayres, op. cit. (nota 450), pp. 68-69.

${ }^{465}$ CARRAZZA, Roque, A., op. cit. (nota 326), p.687.
} 
entendendo que "há uma certa margem de discricionariedade para a definição dos precisos contornos da regra-matriz de incidência", cujos limites encontram-se no texto constitucional. ${ }^{466}$ Ou seja, o legislador constituinte teria se referido a conceitos determinados quando repartiu os critérios materiais dos impostos, pois pensar de outro modo seria permitir que o legislador infraconstitucional definisse os signos ali inseridos, o que significaria esvaziar o esforço daquele. ${ }^{467}$

E conclui que o constituinte originário, ao discriminar as competências tributárias, elegeu "expressões sobejamente conhecidas, estudadas pela doutrina, trabalhadas pela jurisprudência, com clara delimitação de sentido". ${ }^{468}$

Os adeptos da concepção tipológica justificam-se na remissão feita pelo art. 146, da Constituição Federal, relativamente ao papel da lei complementar. Neste artigo a Carta Maga atribui à lei complementar tarefas relativas à competência tributária, em especial no inciso I (“dispor sobre conflitos de competência, em matéria tributária, entre a União, os Estados, o Distrito Federal e os Municípios") e no inciso III, "a" ("estabelecer normas gerais em matéria de legislação tributária, especialmente sobre definição de tributos e de suas espécies, bem como, em relação aos impostos discriminados nesta Constituição, a dos respectivos fatos geradores, bases de cálculo e contribuintes”). Estas seriam demonstrações de que as expressões usadas na outorga das respectivas competências impositivas seriam "tipos" e não "conceitos". Tanto que caberia ao legislador complementar definir-lhes o conteúdo, que não estaria exaustiva e rigidamente delineado na Constituição, e ainda dispor sobre conflitos de competência em matéria tributária entre os entes federativos causados pela falta de limites rígidos em sua repartição. Do contrário, o mencionado papel atribuído ao legislador complementar não faria sentido. 469

Entretanto, para aqueles que sustentam que a Constituição veicula em suas regras de competência "conceitos determinados", o mencionado artigo teria apenas o papel de permitir à lei complementar "definir melhor" o conteúdo dos tais conceitos, explicitando o que já estaria implícita e rigidamente contido no texto constitucional.

Misabel Derzi é enfática em rechaçar a utilização de "tipos" na outorga constitucional de competências. Segundo ela, “o tipo, como ordenação do conhecimento

\footnotetext{
${ }^{466}$ BARRETO, Paulo Ayres, op. cit. (nota 450), p. 72.

${ }^{467}$ Cf. Idem, ibidem, p. 73.

${ }^{468}$ Idem, ibidem, p. 74.

${ }^{469}$ Cf. SCHOUERI, Luis Eduardo, op. cit. (nota 411), p. 119.
} 
em estruturas flexíveis de características renunciáveis, que admite as transições fluidas e contínuas e as formas mistas, não se adapta à rigidez constitucional de discriminação tributária". 470

Necessário ressaltar que, mesmo adotando como premissa o fato de que as regras constitucionais se exprimem por meio de "conceitos", deve-se ter em conta que estes podem sofrer alterações ao longo do tempo. Independentemente da vontade do legislador, os conceitos sofrem modificação da própria realidade social a que dizem respeito. Em outras palavras, as normas constitucionais podem denotar modificações quando submetidas a uma interpretação histórico-evolutiva, e não apenas pela via reformadora efetivada pelo legislador.

Recente decisão do Supremo Tribunal Federal ${ }^{471}$ revela uma evolução de alguns dos signos contidos no texto constitucional relativos à família. Analisando relações homoafetivas, entendeu aquela Corte que deveria ser dado ao art. 1.723 do Código Civil Brasileiro interpretação conforme o texto constitucional, excluindo-se dele qualquer significado que impeça o reconhecimento da união contínua, pública e duradoura entre pessoas do mesmo sexo como constitutiva de uma entidade familiar, entendida esta como sinônimo perfeito de família. ${ }^{472}$

Conforme ressaltou o Min. Ayres Britto em seu voto, “o artigo 1.723 do Código Civil é quase uma cópia do parágrafo $3^{\circ}$ do artigo 226 da CF" ${ }^{473}$, que elenca um rol das famílias, contemplando apenas as famílias heterossexuais constituídas pelo casamento, por união estável, pública e duradoura e, ainda, a monoparental, que é a família que continua constituída entre pai ou mãe e filhos, na ausência de um dos genitores, sem qualquer menção à união homoafetiva estável. É certo também que nenhum dos

${ }^{470}$ DERZI, Misabel de Abreu, op. cit. (nota 452), p. 137.

471 Ação de Descumprimento de Preceito Fundamental (ADPF) n ${ }^{\circ}$ 132-3/800 e Ação Direta de Inconstitucionalidade (ADI) 4277 (julgamento conjunto). Disponível em: <http://www.stf.jus.br/portal/geral/verPdfPaginado.asp?id=433816\&tipo=TP\&descricao=ADPF\%2F132> . Acesso em 19 de julho de 2011.

${ }^{472}$ O STF enviou aos Tribunais de Justiça dos estados brasileiros ofício determinando que seja dada tal interpretação ao assunto. Disponível em: <http://www.slideshare.net/professoradolfo/stf-uniohomoafetiva-oficio>. Acesso em 19 de julho de 2011.

${ }^{473}$ CF.: "Art. 226. A família, base da sociedade, tem especial proteção do Estado. $\S 1^{\circ}$ - O casamento é civil e gratuita a celebração. $\S 2^{\circ}$ - O casamento religioso tem efeito civil, nos termos da lei. $\S 3^{\circ}$ - Para efeito da proteção do Estado, é reconhecida a união estável entre o homem e a mulher como entidade familiar, devendo a lei facilitar sua conversão em casamento. $\$ 4^{\circ}$ - Entende-se, também, como entidade familiar a comunidade formada por qualquer dos pais e seus descendentes. $\S 5^{\circ}$ - Os direitos e deveres referentes à sociedade conjugal são exercidos igualmente pelo homem e pela mulher. [...] (g.n.) 
dispositivos da Constituição Federal que tratam da família proíbe a formação de uma família homoafetiva.

A interpretação do STF embasou-se numa série de princípios e direitos constitucionais que impõem a inclusão das uniões homoafetivas no regime jurídico da união estável, quais sejam: direito à igualdade (art. $5^{\circ}$, caput), direito à liberdade, do qual decorre a autonomia da vontade (art. $5^{\circ}$, II), princípio da dignidade da pessoa humana (art. $1^{\circ}$, IV) e princípio da segurança jurídica. A nova orientação, resultante de interpretação e não de alteração normativa, decorreu de mutações sociais e da pressão de grupos da sociedade, de forma que hoje os cartórios civis estão realizando registros de casamento entre pessoas do mesmo sexo, ainda que no direito positivo não haja qualquer norma neste sentido. $^{474}$

No campo tributário, ainda que os limites dos signos impostos pelo constituinte quando da outorga de competências determinem a amplitude do exercício destas competências tributárias, não se pode conceber que a Constituição Federal não esteja aberta à historicidade social.

Andei Pitten Velloso leciona que não existe uma regra rígida de que haverá invariavelmente alteração ou manutenção de significado dos termos e expressões que a Carta Magna utiliza na outorga de competências, advertindo que pode haver alteração tácita de sentido. ${ }^{475}$

É certo que o "tipo", com sua flexibilidade e fluidez, favorece que as normas se adaptem mais facilmente às mutações sociais e às novas situações, como as inovações tecnológicas, apresentando-se sempre como solução. ${ }^{476}$ Isto explica sua aplicabilidade no Direito Civil, notoriamente no campo contratual e societário; no entanto, a "tipologia" cede lugar à "classificação" e o "tipo" ao "conceito" à medida que cresce a necessidade de segurança jurídica, como no próprio direito civil no campo dos direitos reais e das normas em geral no direito penal e tributário. ${ }^{477}$

${ }^{474} \mathrm{O}$ art. $2^{\circ}$ da Lei n ${ }^{\circ}$ 11.340/2006, "Lei Maria da Penha", reconhece direitos às mulheres independentemente de sua orientação sexual. "Art. $2^{\circ}$ Toda mulher, independentemente de classe, raça, etnia, orientação sexual, renda, cultura, nível educacional, idade e religião, goza dos direitos fundamentais inerentes à pessoa humana, sendo-lhe asseguradas as oportunidades e facilidades para viver sem violência, preservar sua saúde física e mental e seu aperfeiçoamento moral, intelectual e social."

475 VELLOSO, Andrei Pitten, Conceitos e Competências Tributárias, São Paulo, Dialética, 2005, p. 101.

${ }^{476}$ Cf. DERZI, Misabel de Abreu, op. cit. (nota 452), p. 138.

${ }^{477}$ Cf. Idem, ibidem, p. 138. 
As duas correntes, tanto a conceitual quanto a tipológica, não dispensam o legislador complementar de cumprir o disposto no art. 146 da CF de 1988. A grande diferença está em que, entendidas as normas constitucionais atributivas de competência como alusivas a conceitos, e não a tipos, essa "melhor definição" levada a efeito pelo legislador complementar terá limites mais estreitos (embora nem sempre muito claros) dentro dos quais se deverá adstringir. Caso ultrapasse esses limites, incorrerá em inconstitucionalidade, a ser objeto de controle por parte do STF.

Compreendidas, no entanto, as referidas normas como veiculadoras de tipos, por sua vez, a liberdade do legislador complementar será um pouco maior, não sendo possível ao STF afirmar inconstitucional as definições por ele veiculadas na determinação do sentido dos tipos constitucionalmente previstos.

Em suma, para a corrente conceitual, a palavra final quanto ao significado dos signos utilizados nas normas constitucionais caberá quase que exclusivamente ao STF, enquanto na tipológica o legislador complementar terá também parcela importante de poder nessa determinação.

No que tange ao entendimento do Supremo Tribunal Federal sobre o tema, Paulo Ayres Barreto afirma que há naquela corte uma tendência de reconhecimento da utilização de conceitos determinados na distribuição de competências, exemplificando com os seguintes casos: (i) ISS sobre a locação de bens móveis, (ii) ICMS nas importações realizadas por pessoas físicas, (iii) IPTU do arrendatário do bem, (iv) contribuição previdenciária nos pagamentos efetuados a avulsos, autônomos e administradores. ${ }^{478}$

No entanto, em recente voto naquele Tribunal, o Ministro Cezar Peluso reafirmou que a Constituição Federal não define uma série de institutos dos quais se utiliza como "tributo", "propriedade", "família", entre outros, e que, portanto, não há no texto constitucional conceitos formais ou pré-definidos. Acrescentou, ainda, que não seria mesmo conveniente que o Texto Maior trouxesse tais conceitos, visto que deve adaptar-se “às necessidades históricas da evolução socioeconômica, segundo sua vocação de abertura permanente". 479

Seria, então, essa flexibilidade constitucional necessária para que as mutações sociais e culturais pudessem ser refletidas no texto constitucional sem que se promovessem inúmeras alterações.

${ }^{478}$ BARRETO, Paulo Ayres, op. cit. (nota 450), p. 80.

${ }^{479}$ Trecho do voto-vista do Min. Cezar Peluso no RE 346.084/PR, Relator Ilmar Galvão, 08/11/2005, item 5. 
Cabe ressaltar que no mencionado voto-visto, o Ministro Cezar Peluso enfatizou que as palavras na linguagem natural, assim como na técnica, de que se vale o direito para construção do ordenamento jurídico possuem uma vaguidade; no entanto, há um "conteúdo semântico mínimo recognoscível a cada vocábulo", que serve de limite de resistência à atividade do intérprete. ${ }^{480}$

Portanto, o fato de a Constituição Federal não prescrever o significado dos termos de que se utilizou na outorga de competência não franqueia ao intérprete a assunção de qualquer acepção. Sua tarefa inicia-se pela verificação, no próprio ordenamento, da existência de algum valor semântico semelhante que possa guiar o sentido constitucional. E adverte o Ministro: "se há correspondente semântico na ordem jurídica, a presunção é de que a ele se refere o uso constitucional". ${ }^{481}$

E neste ponto faz uma digressão sobre a evolução no uso da palavra "fatura", concluindo que a evolução histórica, ao alterar o foco da importância econômica do conceito de comerciante para o de empresa, justificaria a revisão do signo "faturamento", que passaria a denotar as vendas realizadas pela empresa.

Desta forma, o conceito pré-existente no ordenamento, tomado pelo intérprete, sofreria uma "acomodação prática", em função das exigências históricas da evolução dos conceitos, “dentro dos limites da resistência semântica do vocábulo". ${ }^{482}$

No mesmo julgamento do RE 346.084-6/PR, o Min. Gilmar Mendes afirmou em relação à base de cálculo da Confins não existir na $\mathrm{CF}$ um conceito de "faturamento", o que deveria ser fixado por lei. Nessa linha, reconheceu não existir na Constituição Federal um específico conteúdo em detrimento de todos os outros, demonstrando que a questão está longe de encontrar-se pacificada na jurisprudência.

De qualquer forma, certo é que há um certo grau de elasticidade tanto nos tipos como nos conceitos e que cabe ao legislador complementar desempenhar um papel de aperfeiçoamento do texto constitucional. Nesta função de complementação lhe é consagrada uma certa margem de liberdade para versar tema fundamentalmente constitucional, devendo atuar nos obscuros da Constituição ciente de que esta liberdade é relativa e condicionada aos limites lógico-sintáticos dos signos constitucionais, respeitando sua amplitude semântica, assim como os princípios que a norma constitucional afirma.

\footnotetext{
${ }^{480}$ Trecho do voto-vista do Min. Cezar Peluso no RE 346.084/PR, Relator Ilmar Galvão, 08/11/2005, item 5. ${ }^{481}$ Idem, ibidem, item 5.

${ }^{482}$ Idem, ibidem, item 8.
} 
Destarte, estamos convencidos de que o constituinte originário se utilizou na outorga de competências de "conceitos", que estão sujeitos a alterações de significado decorrentes das transformações sociais, econômicas e políticas, cabendo ao legislador complementar delimitar as zonas de confronto entre um e outro tributo, captando e refletindo as evoluções históricas. 


\section{O COMÉRCIO ELETRÔNICO E O IMPOSTO SOBRE SERVIÇOS DE QUALQUER NATUREZA}

O Imposto sobre Serviços, que abrange inúmeros fatos geradores descritos na Lista Anexa à Lei Complementar no 116/2003, enseja inúmeras discussões sobre as quais se ocupam, sem obter um consenso, os contenciosos administrativos, a jurisprudência e a prática fiscal. De modo geral, discute-se a natureza jurídica da lista (exaustiva ou exemplificativa), os conflitos entre o ICMS e o ISS em algumas operações, a natureza jurídica de atividades constantes na lista que não seriam serviços, entre outros. ${ }^{483}$

Especificamente em relação ao comércio eletrônico os debates relacionam-se, de modo geral à definição do Município competente para tributar as operações realizadas por meio de estabelecimentos virtuais e a tributação da cessão e licenciamento de bens virtuais, negociados através de transações eletrônicas.

Neste sentido, pretendemos neste capítulo desvendar todo o arcabouço teórico relativo aos aspectos material e espacial do tributo. Neste sentido, iremos perquirir o alcance e a significação do signo "serviço", da expressão "serviços de qualquer

${ }^{483}$ Cf. SANTI, Eurico Marco, ISS versus ICMS na Prestação de Serviços, Revista Dialética nº 186, p. 25. 
natureza", do conceito de "estabelecimento prestador", assim como dos elementos de conexão fixados na legislação complementar.

\subsection{A Regra-Matriz de Incidência do Imposto sobre Serviços de Qualquer Natureza}

O texto constitucional, ao outorgar a competência impositiva relativa ao ISS em seu art. 156, III, apontou os traços gerais definidores do tributo, demarcando como seu critério material "os serviços de qualquer natureza, não compreendidos no art. 155, II, definidos em lei complementar".

Fazendo-se a transposição para a estrutura mínima da regra-matriz de incidência, que tem como objetivo exatamente reduzir a dificuldade dos enunciados normativos ${ }^{484}$, sistematizamos, a partir do texto constitucional, os seguintes critérios relativos ao Imposto Sobre Serviços de Qualquer Natureza:

Hipótese:

- critério material: (prestar) os serviços de qualquer natureza, não compreendidos no art. 155, II, e definidos em lei complementar;

- critério espacial: os limites geográficos do Município;

- critério temporal: momento da prestação do serviço;

Consequente:

- critério pessoal: sujeito ativo - Municípios/sujeito passivo: prestador de serviços;

- critério quantitativo: base de cálculo - preço do serviço/alíquota - aquela prevista na legislação ordinária, obedecido o limite máximo imposto pela Lei Complementar e o limite mínimo previsto no art. 88 da ADCT - ATO DAS DISPOSIÇÕES CONSTITUCIONAIS TRANSITÓRIAS ${ }^{485}$.

Estariam assim delineados no texto constitucional todos os critérios relativos ao tributo, ainda que o comando específico do artigo 156, III refira-se somente ao critério material, sendo os outros extraídos por uma interpretação sistemática da Carta

${ }^{484}$ Cf. CARVALHO, Paulo de Barros, op. cit. (nota 19), p. 683.

${ }^{485}$ CF 88 . O art. 88 da ADCT foi incluído pela Emenda Constitucional n ${ }^{\circ} 37 / 2002$ - Art. 88. Enquanto lei complementar não disciplinar o disposto nos incisos I e III do $\S 3^{\circ}$ do art. 156 da Constituição Federal, o imposto a que se refere o inciso III do caput do mesmo artigo:

I - terá alíquota mínima de dois por cento, exceto para os serviços a que se referem os itens 32,33 e 34 da Lista de Serviços anexa ao Decreto-Lei n ${ }^{\circ}$ 406, de 31 de dezembro de 1968. 
Magna. Desta forma, é possível precisar que o tributo somente poderá incidir sobre os serviços prestados no território do Município detentor da competência, considerando-se que o legislador constitucional adotou um critério territorial para prover a repartição das competências impositivas. ${ }^{486}$ Deste modo, a lei instituidora do tributo em determinado Município somente pode alcançar os fatos jurídico-tributários ocorridos nos limites de seu território, ou em que haja um elemento de conexão, definido legalmente como suficiente para configurar a incidência do imposto, como a identificação do efetivo "estabelecimento prestador".

\subsubsection{As Funções da Lei Complementar e a Lista de Serviços}

A Constituição Federal estipulou, de modo minucioso, as materialidades em relação às quais as pessoas jurídicas de direito público estão habilitadas a instituir seus tributos. Neste sentido, atribuiu aos Municípios ${ }^{487}$, dentre outras, a competência para a instituição do Imposto sobre Serviços de Qualquer Natureza - ISSQN, em seu artigo 156, III, nos seguintes termos:

Artigo 156. Compete aos Municípios instituir impostos sobre:

[...]

III - serviços de qualquer natureza, não compreendidos no artigo 155, II, definidos em lei complementar. (g.n.)

$[\ldots]$

De se notar que a Carta Magna fixou o campo de incidência do ISS de modo residual, por um processo de exclusão dos serviços já atribuídos aos Estados no art. 155, II da Constituição Federal. Vale dizer, delineou o âmbito de abrangência do tributo municipal, excluindo aqueles serviços já atribuídos aos Estados (serviços de transporte interestadual e intermunicipal e de comunicação), além de exigir a edição de lei complementar com o propósito de "definir" os serviços sobre os quais incidirá o referido imposto.

Destarte, no tocante ao ISS, além das atribuições gerais estabelecidas no art. 146 da Constituição Federal, conferiu o constituinte originário à lei complementar a função de delimitar aqueles serviços sobre os quais incidirá o imposto. É que o constituinte

${ }^{486}$ Cf. CARRAZZA, Roque, op. cit. (nota 326), p. 967.

${ }^{487}$ O Distrito Federal cumula esta competência com aquela atribuída aos Estados, sendo, portanto, também competente para instituir e arrecadar o ISS, conforme art. 147, CF. 
originário elegeu a legislação complementar para narrar minuciosamente a complementação da outorga de competência por ele iniciada. ${ }^{488}$

O inciso III do art. 146 da CF confere à lei complementar a missão de "estabelecer normas gerais em matéria de legislação tributária". O campo de abrangência do signo "gerais" na definição destas normas de direito tributário deve ser tomado na acepção de que o termo tem a significação de que "atinge a todos os entes e todos os tributos".

A preocupação de sistematização das regras de direito tributário é uma preocupação antiga no Brasil. Aliomar Baleeiro, antes da edição do Código Tributário Nacional, já manifestava sua preocupação com a existência de "mais de 2000 aparelhamentos fiscais" no país, que se regiam por textos diversos de direito tributário. Segundo ele, "naquela época, cada Estado ou Município regulava diversamente os prazos de prescrição, as regras de solidariedade, o conceito de fato gerador, as bases de cálculo dos impostos que lhe foram distribuídos etc.”. ${ }^{489}$

Ou seja, havia, em suas palavras, um "pandemônio" normativo, cuja solução seria possível por meio da edição de leis complementares pela União, atuando a referida lei como lei nacional.

De fato, essa opção do Constituinte derivado corrobora o modelo federativo centrípeto adotado pelo Brasil, em que há concentração de poderes e competências na União, em detrimento de um modelo centrífugo de federação, como o norte-americano, em que há maior autonomia e liberdade para os Estados-membros.

$\mathrm{O}$ fato de a Constituição Federal deferir à lei complementar a regulamentação de tais matérias, notadamente normas gerais em direito tributário, não representa qualquer ofensa ao pacto federativo, pelo contrário, o fortalece, na medida em que delimita as competências de cada ente federado, sistematizando a outorga de competências e conferindo estabilidade aos entes políticos e segurança aos contribuintes.

Neste sentido, concluiu Eurico de Santi que

as normas gerais de direito tributário são sobrenormas que, dirigidas à União, Estados, Municípios e Distrito Federal, visam à realização das funções certeza e segurança do direito, estabelecendo a uniformidade do

${ }^{488}$ Cf. CARVALHO, Paulo de Barros, op. cit. (nota 19), p. 681.

${ }^{489}$ SANTI, Eurico Marcos Diniz, op. cit. (nota 366), p. 329. 
Sistema Tributário Nacional, em consonância com princípios e limites impostos pela própria Constituição Federal. (g.n.) ${ }^{490}$

O importante é que tais normas gerais imponham o mesmo tratamento aos diversos entes, preservando desta forma o princípio federativo.

A lei complementar editada nos termos do disposto no art. 156, III da CF, que veicula a lista de serviços relativa ao ISS, possui função dúplice; sendo o veículo introdutor de normas jurídicas tributárias definidoras de quais os serviços ensejarão a incidência do tributo, cumpre ainda, concomitantemente, a tarefa de evitar eventuais conflitos de competência entre os entes da Federação. ${ }^{491}$

Uma interpretação meramente gramatical da norma mencionada poderia levar a concluir que os Municípios somente poderiam tributar os serviços que estivessem incluídos na referida lista. No entanto, o ordenamento deve sempre ser interpretado de modo sistêmico, o que obriga o exegeta a considerar, concomitantemente a tal norma, todos os princípios tributários, em especial, no caso, o da autonomia municipal e o federativo, o que o levaria a concluir de modo diverso. ${ }^{492}$

É que, como o município em nosso sistema federativo é pessoa política, que goza de autonomia e tem competência para arrecadar seus tributos (art. 30, III, CF), não seria possível que qualquer lei, ainda que complementar, viesse a aumentar ou diminuir, ou muito menos anular o campo de incidência do ISS. ${ }^{493}$

Neste sentido, a lição de Roque A. Carrazza é que a lei complementar exigida pela Constituição Federal em relação ao ISS visa apenas a dispor sobre conflitos de competência entre este tributo e os outros delineados na Magna Carta. ${ }^{494}$ Desta forma, a norma estatuída no art. 156, III seria de eficácia plena e aplicabilidade imediata, e atuaria o legislador complementar apenas naqueles nichos em que se situam fatos jurídicos que contemplam interpretações dúbias, levando a conflitos de incidência. ${ }^{495}$

No entanto, parte da doutrina, representada por Edvaldo Brito e José Afonso da Silva, defende que o comando constitucional inserto no inciso III do art. 156 da Constituição Federal é norma de eficácia limitada, visto que a determinação da edição de

\footnotetext{
${ }^{490}$ SANTI, Eurico Marcos Diniz, op. cit. (nota 366), p. 328.

${ }^{491}$ Cf. CARVALHO, Paulo de Barros, op. cit. (nota 19), p. 682.

${ }^{492}$ CARRAZZA, Roque, op. cit. (nota 326), p. 959.

${ }^{493}$ Cf. Idem, ibidem, p. 959.

${ }^{494}$ Cf. CARRAZZA, Roque, op. cit. (nota 326), p. 959.

${ }^{495}$ Cf. Idem, ibidem, p. 960.
} 
lei complementar não pode ser considerada apenas "uma recomendação sem eficácia jurídica”. 496

Aires Barreto imputa o problema à procedência do tributo que, conforme analisamos no capítulo quarto, surgiu sob influência do Imposto sobre Valor Adicionado, criado no âmbito da Comunidade Econômica Europeia. Constituída, à época, por países quase na totalidade com a forma Unitária de Estado, a transposição da sistemática criada para aquela realidade se mostrava inadequada a um país como o nosso, com forma de estado Federativo, composto por três níveis de entes que gozam de autonomia. ${ }^{497}$

A argumentação ganha corpo ao admitirmos que não poderiam os municípios ficar à mercê de lei nacional para exercerem uma prerrogativa que lhes foi concedida pela própria Constituição Federal. Ou seja, pensar de forma diversa seria admitir que, caso fosse a atual Lei Complementar n. 116 revogada e o Congresso Nacional não promovesse a edição de outra, estariam os municípios impedidos de instituir o ISS, promovendo o esvaziamento de uma competência imposivita, num raciocínio que, ainda que absurdo, leva-nos a compreender a extensão do problema. ${ }^{498}$

Souto Maior Borges adverte que "à lei complementar não incumbe fixar limites à competência tributária dos Municípios". 499 E observa que admitir de forma diversa seria transmudar nossa Constituição, em termos de atribuição de competência, de rígida em flexível, estando delineado por exclusão no próprio texto constitucional o âmbito de tributação dos municípios.

O legislador complementar, ao definir os serviços que estarão sujeitos à incidência do ISS, não estará caracterizando a hipótese de incidência do tributo, ou estaria invadindo o campo de competência impositiva reservado às leis ordinárias dos municípios. 500

No entanto, para Bernardo Ribeiro de Moraes, ao definir os serviços, a lei complementar não apenas enuncia as qualidades e as características de cada serviço. Para ele, “definir também é sinônimo de fixar, marcar. Assim, 'definidos em lei complementar' quer dizer estabelecidos em lei complementar, isto é fixados, indicados, arrolados." ${ }^{501} \mathrm{E}$

\footnotetext{
${ }^{496}$ Cf. EMERENCIANO, Adelmo da Silva, op. cit. (nota 39), p. 169.

${ }^{497}$ Cf. BARRETO, Aires, op. cit. (nota 438), p. 106.

${ }^{498}$ Cf. CARRAZZA, Roque, op. cit. (nota 326), p. 960.

${ }^{499}$ BORGES, José Souto Maior, Lei Complementar Tributária, São Paulo, Ed. Revista dos Tribunais, EDUC, 1975, p. 186.

${ }^{500}$ Cf. Idem, ibidem, p. 187.

${ }^{501}$ Cf. MORAES, Bernardo Ribeiro, op. cit. (nota 425), pp. 71-72.
} 
certo que o constituinte originário distinguiu formalmente a competência para definir os serviços daquela para tributá-los, vislumbrando Souto Maior Borges na formulação do art. 156, III duas regras distintas: (i) uma outorga competência aos municípios para instituir o imposto sobre serviços de qualquer natureza não compreendidos na competência tributária dos Estados e (ii) uma segunda que outorga competência à União, enquanto ente nacional, mediante lei complementar, para definir tais serviços. ${ }^{502}$

Limitando-se a tarefa exegética às normas contidas no texto constitucional, conclui-se, por um processo de exclusão, que os Municípios estão autorizados a instituir o imposto sobre todos os serviços que não estejam incluídos na competência dos Estados e da União, a teor da lição de Aliomar Baleeiro. ${ }^{503}$

Por óbvio que, de qualquer forma, estará o legislador, no mister de cumprir o que exige a CF no art. 156, III, jungido a todas as normas de estrutura contidas naquele altiplano, não lhe sendo permitido extrapolar na missão atribuída, pormenorizando aquilo que pretendeu o constituinte. Tal diretiva foi reforçada pelo constituinte derivado, que alterou a redação do $\S 3^{\circ}$ do art. 156, acrescendo-lhe alguns incisos. Vejamos:

$\S 3^{\circ}$ Em relação ao imposto previsto no inciso III do caput deste artigo, cabe à lei complementar:

I - fixar as suas alíquotas máximas e mínimas;

II - excluir da sua incidência exportações de serviços para o exterior;

III - regular a forma e as condições como isenções, incentivos e benefícios fiscais serão concedidos e revogados.

Trata-se, na verdade, da atribuição de novas funções à lei complementar do ISS, oriundas de alterações promovidas no texto constitucional. No que tange à exclusão do imposto sobre exportações, trata-se de medida que imuniza do imposto as exportações, visando a retirar, ou minimizar, a carga tributária das exportações - uma imposição do mundo globalizado.

${ }^{502}$ Cf. BORGES, José Souto Maior, op. cit. (nota 499), p.193.

${ }^{503}$ Cf. Idem, ibidem, p. 186. 


\subsubsection{Critério Material do Imposto sobre Serviços de Qualquer Natureza}

O critério material da regra matriz assume especial relevância na medida em que identifica os eventos eleitos pelo legislador como necessários e suficientes à incidência da norma tributária. Como é cediço, no critério material de todo imposto há sempre a referência a um comportamento humano, que consubstancia, no dizer de Alfredo Augusto Becker, um "fato signo presuntivo de capacidade contributiva", isto é, revelador de riqueza. ${ }^{504}$

Esse núcleo deve compreender, invariavelmente, uma ação representada por um verbo mais complemento, ou seja, um verbo transitivo; Paulo de Barros Carvalho adverte para a "transcendente importância do verbo", sendo que não se podem utilizar aqueles impessoais, sem complementos (intransitivos) ou sem sujeito, que comprometeriam os efeitos da operatividade normativa. Admitir verbos deste jaez seria admitir a incidência normativa a fenômenos naturais, como chover, existir. Além disto, deve-se recordar que o direito regula, precipuamente, condutas intersubjetivas. Portanto, "é forçoso que se trate de verbo pessoal e de predicação incompleta, o que importa a obrigatória presença de um complemento". 505

No entanto, o legislador constitucional, ao definir o campo material de incidência do Imposto sobre Serviços de Qualquer Natureza, limitou-se a revelar o complemento do critério material: "serviços". Desta forma, costuma-se pressupor que o critério material do ISS corresponderia a "prestar + serviços". Isto porque deve haver uma ação, complementada por um predicado verbal, a ser praticada por um sujeito em determinadas coordenadas de tempo e espaço, de maneira que se possa individualizar o obrigado perante o Estado, identificando aquele que exerceu a atividade. Esclarece Roque Carrazza que "em rigor, não são os serviços que vêm tributados por meio de ISS, mas as pessoas físicas ou jurídicas, que em caráter negocial, os prestam". 506

\footnotetext{
${ }^{504}$ Nos termos do disposto no parágrafo $1^{\circ}$ do art. 145 da Constituição Federal, "sempre que possível, os impostos terão caráter pessoal e serão graduados segundo a capacidade econômica do contribuinte, facultado à administração tributária, especialmente para conferir efetividade a esses objetivos, identificar, respeitados os direitos individuais e nos termos da lei, o patrimônio, os rendimentos e as atividades econômicas do contribuinte". Trata-se do primado da capacidade contributiva.

${ }^{505}$ CARVALHO, Paulo de Barros, op. cit. (nota 338), p. 287.

${ }^{506}$ CARRAZZA, Roque A., op. cit. (nota 326), p. 958.
} 
Aires F. Barreto leciona que o aspecto material da hipótese de incidência do ISS “é a conduta humana (prestação de serviço), consistente em desenvolver um esforço visando a adimplir uma obrigação de fazer". 507

Nos questionamos neste sentido se poderia o legislador complementar ter optado por eleger outro verbo para atrelar ao complemento, definindo o critério, por exemplo, como "tomar serviços". É o que acaba por ocorrer na imposição da responsabilidade tributária, vez que aquele que tem a obrigação de apurar, declarar e carrear os valores ao sujeito ativo, nos termos do art. 150 do CTN, é o tomador do serviço.

No sentir de Coelho e Derzi, "a Carta Magna preferiu considerar os serviços sob o ângulo do prestador (não do usuário) no âmbito de incidência do ISS, fato igualmente indicativo de capacidade econômica". E concluem: "Em decorrência, a nossa ordem jurídica aponta como contribuinte do imposto o "prestador do serviço". 508

Um robusto fundamento constitucional para negar a incidência do ISS sobre a fruição dos serviços é aduzido por Marcelo Caron; segundo o autor, o artigo 156, II da Constituição Federal, ao delimitar o critério material do ISS, atribui-lhe "os serviços" e (excepcionando os serviços de competência dos Estados), complementa, "não compreendidos no artigo 155, II", isto é, exclui as "prestações de serviços de transporte interestadual e intermunicipal e de comunicação, ainda que as operações e as prestações se iniciem no exterior". 509

Por outro giro, a competência municipal é definida constitucionalmente por exclusão das "prestações de serviço" já incluídas na esfera de competência dos Estados, de forma que se deve entender que se tratam todas (municipais e estaduais) de "prestações de serviço".

A existência de um valor a título de contraprestação a ser paga pelo tomador ao prestador, pela utilidade imaterial, é imprescindível para que se estabeleça a relação jurídico-tributária relativa ao ISS. O conteúdo econômico, imprescindível a todos os fatos jurídicos colhidos pelo legislador para constituir o critério material dos impostos,

\footnotetext{
${ }^{507}$ BARRETO, Aires F., op. cit. (nota 438), p. 423.

${ }^{508}$ COELHO, Sacha Calmon Navarro e DERZI, Misabel Abreu Machado, O Aspecto Espacial da Regramatriz do Imposto Municipal Sobre Serviços, à Luz da Constituição, In Revista Dialética de Direito Tributário n ${ }^{\circ} 88$, São Paulo, Dialética, 2003, p. 136.

${ }^{509}$ Cf BAPTISTA, Marcelo Caron, op. cit. (nota 177), pp. 258-259.
} 
decorrente da diretiva do princípio da capacidade contributiva, encontra-se no preço do “serviço" em si, no seu caráter oneroso. ${ }^{510}$

Destarte, não é todo e qualquer serviço que provoca a incidência do Imposto sobre Serviços - ISS, mas somente aquela prestação de serviços a terceiros de uma utilidade (material ou imaterial), com conteúdo econômico, sob regime de direito privado, isto é, em caráter negocial, mas não trabalhista. ${ }^{511}$

Elucida Paulo de Barros Carvalho que não estão englobados no campo de incidência do tributo os serviços públicos, que abrangidos pela imunidade disposta no art. 150, IV, a, da Constituição Federal, o trabalho realizado para si próprio que não possui caráter econômico e aquele praticado sob vínculo empregatício. ${ }^{512}$ Além disto, na dicção do artigo 156, III, estão ainda excluídos do campo de incidência do imposto os serviços de transporte interestadual e intermunicipal e de comunicação, inseridos no âmbito de competência dos Estados e do Distrito Federal.

\section{3. "Serviços de Qualquer Natureza"}

A expressão "serviços de qualquer natureza" fixa constitucionalmente o núcleo da materialidade do Imposto sobre Serviços. Desta forma, na medida em que seu significado delimita o campo de imposição do tributo municipal, investigar seus contornos assume especial relevância. Neste sentido, a definição do conceito de "serviços de qualquer natureza" se presta a identificar os atributos dos fatos jurídicos por ele abrangidos. ${ }^{513}$

\subsubsection{Conceito e Definição - Distinção}

Embora comumente "conceito" e "definição" sejam utilizados como sinônimos, esses vocábulos não possuem, rigorosamente, o mesmo significado. Tanto assim, que é possível se definir um conceito, identificando-lhe os atributos, isto é, determinando-lhe um significado. ${ }^{514}$

\footnotetext{
${ }^{510}$ Cf. CARVALHO, Paulo de Barros, op. cit. (nota 19), p. 686.

${ }^{511}$ Cf. CARRAZZA, Roque, op. cit. (nota 326), p. 958.

512 Cf. CARVALHO, Paulo de Barros, op. cit. (nota 19), p. 685.

${ }^{513}$ Cf. GAMA, Tácio Lacerda, op. cit. (nota 18), p.121.

${ }^{514}$ Cf. Idem, ibidem, p. 121.
} 
"Conceito" é a compreensão que alguém tem de uma palavra, a noção, a ideia. Tárek Moyses Moussallém ensina que "conceito" é um critério criado em nossas mentes para distinguirmos os objetos. ${ }^{515}$ Já definição está associada à delimitação exata do termo, ao estabelecimento de limites. ${ }^{516}$

Podemos dizer que conceituar é atribuir um conjunto de ideias que representam as propriedades de determinado objeto. Já definir é estabelecer, para determinado vocábulo, os fins, os confins, ou seja, demarcar, determinar, fixar. ${ }^{517}$ Schoueri, citando Strache, ressalta que na definição de um conceito não há a necessidade de se mencionar todas as suas características, sendo suficiente apenas aquelas que permitam diferenciar este de outros conceitos; assim, definir um conceito implica na escolha de algumas de suas características. ${ }^{518}$

Para Irving Copi, definir um termo é explicar seu significado, e as definições (os produtos) são sempre símbolos, já que apenas estes possuem significados que podem ser explicados pelas definições. ${ }^{519}$

A definição possui grande relevância para a ciência, pois é por meio dela que se especifica qual será seu objeto de estudo, posto que "para definir um conceito é necessário apontar critérios de distinção entre os objetos que o integram e os objetos que não o integram”. 520

Tácio Lacerda Gama, por seu turno, conclui que um conceito abriga um conjunto de objetos, cuja vagueza e ambiguidade podem ser reduzidas por meio da definição de seus critérios de uso, havendo um conceito distinto para cada um destes critérios. $^{521}$

Segundo suas funções, os conceitos jurídicos podem ser classificados, na lição de Eros Grau, em (i) meramente formais; (ii) os regulae juris e (iii) os tipológicos (fattispecie). Os conceitos jurídicos meramente formais auxiliam na expressão da valoração normativa, indicando "posições lógicas indispensáveis à estruturação de uma

${ }^{515}$ Cf. MOUSSALlÉM, Tárek Moysés. Fontes do Direito Tributário, São Paulo, Editora Max Limonad, p. 50 .

${ }^{516}$ Verbete "definição", HOUAISS, op. cit. (nota 54). Acesso em 13 de setembro de 2012.

${ }^{517}$ Cf. CARVALHO, Paulo de Barros, op. cit. (nota 19), p. 704.

${ }^{518}$ Cf. SCHOUERI, Luis Eduardo, op. cit. (nota 455), p. 245.

${ }^{519}$ Cf. COPI, Irving M., Introdução à lógica, Mestre Jou, 2a . ed., 1978, pp.105-113.

${ }^{520}$ GAMA, Tácio Lacerda, op. cit. (nota 18), p.121.

${ }^{521}$ Cf. Idem, ibidem, p. 121. 
teoria geral do direito." 522 São exemplos de "conceitos jurídicos meramente formais" as expressões "ônus", "sujeito jurídico", “direito", “obrigação".

Os regulae juris, sem possuir um significado próprio, "sintetizam o conteúdo de um conjunto de normas jurídicas", exprimindo um sistema normativo. Neste sentido, o conceito de "propriedade", cuja significação para o intérprete resume toda a disciplina normativa a ela pertinente relativa "ao modo de aquisição, os poderes, faculdades e deveres decorrentes da aquisição de uma posição jurídica subjetiva em relação a um bem". 523

Os conceitos jurídicos tipológicos (fattispecie) seriam, na verdade, noções que possuem universalmente um sentido histórico que representa ideais de indivíduos, grupos, países, referindo-se a fatos típicos da realidade, representados pelos seguintes termos: "boa-fé", "bom pai de família", "coisa", "bem”, “dolo", “culpa", "erro". ${ }^{524}$ Apesar de integrarem o contexto normativo, seu conteúdo é extrajurídico, pois se referem à classificação tipológica da realidade social, cujo sentido é o da linguagem comum.

Neste contexto, revela Eros Grau que são os conceitos jurídicos tipológicos é que se dizem "indeterminados", ao passo que os "meramente formais", porque abstratos e dissociados da realidade histórica, e os "regulae juris", que sintetizam o conteúdo de um sistema normativo, não apresentam qualquer indeterminação. Ademais, "conceito" enquanto essência de ideias não poderia ser indeterminado, sendo a indeterminação dos termos que o expressam e não do conceito. ${ }^{525}$

$\mathrm{Na}$ classificação proposta pelo autor, teria o constituinte se utilizado na designação das competências impositivas daqueles conceitos "regulae juris", expressões que sintetizam todo o conteúdo normativo a eles relativo, como "propriedade", "faturamento", "serviços", "renda", entre outros.

\footnotetext{
${ }_{522}^{5 R A U}$, Eros Roberto, O Direito Posto e o Direito Pressuposto, São Paulo, Malheiros, 2008, p.198.

523 Idem, ibidem, p.199.

${ }^{524}$ Cf. GRAU, Eros Roberto, op. cit. (nota 522), p.199.

${ }^{525}$ Cf. Idem, ibidem, p. 196.
} 


\subsubsection{Os Propósitos da Definição}

Uma das funções primordiais da definição é eliminar o vício de ambiguidade inerente à maioria dos vocábulos. Ambiguidade pode ser entendida como a propriedade que possuem diversas unidades linguísticas (morfemas, palavras, locuções, frases) de significar coisas diferentes, isto é, de admitir mais de uma leitura. O direito tributário é repleto de vocábulos que padecem da ambiguidade, como "tributo", que experimenta seis significações diversas. ${ }^{526}$

Em regra, este problema pode ser solucionado pela extração do sentido atribuído pelo próprio contexto em que está inserido determinado termo. Contudo, quando isto não for possível, pode-se resolver a disputa verbal dando a definição do vocábulo. ${ }^{527}$

A necessidade de definir um termo pode surgir também quando se depara com termos que possuem certa vaguidade, em que se torna imperioso aclarar seu significado. Apesar de haver palavras que são, simultaneamente, vagas e ambíguas, tais propriedades são muito distintas e não se confundem. ${ }^{528}$ Vaguidade é uma qualidade, característica ou condição de um signo, que se refere a algo ou alguém e que se introduz no discurso pela primeira vez, ou cuja identidade não se deseja especificar, definir ou particularizar. Assim, vago é o juízo no qual o sujeito não recebe definição ou determinação precisa, ou de termo cuja significação é indeterminada.

Copi alerta para a gravidade da existência de termos vagos ou ambíguos na área jurídica e defende que seja inserida no próprio texto normativo a definição da referência sígnica sobre a qual possam pairar dúvidas, ressaltando que, caso contrário, deverá o tribunal competente trazer a definição que permita uma aplicação clara da norma. $^{529}$

As definições podem ser de cinco tipos: (i) estipulativas; (ii) lexicográficas; (iii) aclaradoras; (iv) teóricas; e (v) persuasivas. A definição estipulativa

${ }^{526}$ A palavra tributo, dentro do contexto econômico-tributário, pode significar: (i) quantia em dinheiro; (ii) prestação correspondente ao dever jurídico do sujeito passivo; (iii) direito subjetivo que é titular o sujeito ativo; (iv) sinônimo de relação jurídica tributária; (v) norma jurídica tributária; e (vi) norma, fato e relação jurídica.

${ }^{527}$ COPI, Irving M., op. cit. (nota 519), p.106.

${ }^{528}$ Cf. Idem, ibidem, p. 109.

${ }^{529}$ Cf. Idem, ibidem, p.108. 
ocorre quando se introduz um termo totalmente inédito, quando há total liberdade de lhe estipular um significado. ${ }^{530}$

A definição estipulativa, ou legal, firma o significado de uma expressão utilizada em um texto normativo, institucionalizando seu conteúdo. Desta forma, o legislador, ao restringir o alcance ou introduzir um determinado termo em uma norma, confere-lhe precisão e uniformidade.

Por sua vez, a definição lexicográfica é utilizada quando a palavra já possui uso estabelecido, mas é ambígua ou seu receptor necessita ampliar seu vocabulário. Já a definição aclaradora é aquela utilizada para as palavras vagas, em que há a necessidade de decidir num caso limítrofe. Ou seja, não é possível determinar de modo claro qual o significado que deva ser empregado, de modo que a definição aclaradora irá além do uso estabelecido.

Segundo Copi, este tipo de definição costuma ser muito utilizado em decisões de caráter legal. ${ }^{531}$ Assim, são definições aclaradoras aqueles argumentos utilizados pelos juristas para justificar uma decisão, que não se limitam ao uso estabelecido, nem se confundem com uma definição estipulativa. Têm como guia a intenção do legislador e o interesse público. ${ }^{532}$

Por "definições teóricas", entendemos aquelas que formulam uma caracterização teoricamente adequada aos objetos a que se aplicam. São proposições teóricas discutíveis, que vão sendo sucessivamente substituídas à medida que o conhecimento e a compreensão teóricos evoluem. Finalmente, definição persuasiva é aquela destinada a influenciar atitudes.

Enfim, de um modo geral, definir é dar o significado de um termo que, por sua vez, pode ter diferentes sentidos. Os termos genéricos ou de classes apresentam um significado "intensivo" ou "conotativo" e outro "extensivo" ou "denotativo". Apontar o "significado denotativo" de um signo é estabelecer à qual classe de objetos ele pertence; assim, um termo genérico denota os objetos aos quais poderá ser aplicado.

As significações são "intensivas" ou "conotativas" quando definidas em função das qualidades ou propriedades dos objetos de uma determinada classe. A "conotação", por sua vez, possui três diferentes aspectos: (i) subjetivo; (ii) objetivo; e (iii)

${ }^{530}$ Cf. COPI, Irving M., op. cit. (nota 519), p.117.

${ }^{531}$ Cf. Idem, ibidem, p. 117.

${ }^{532}$ Cf. Idem, ibidem, p. 117. 
convencional. Conotação subjetiva refere-se a um conjunto de propriedades atribuído a uma palavra por determinada pessoa, isto é, é o conjunto de qualidades que este sujeito acredita serem inerentes à própria extensão da palavra. ${ }^{53}$ Por ser uma interpretação particular, pode variar de sujeito para sujeito, não sendo adequado utilizá-la com a finalidade de definir.

Já a conotação objetiva não varia conforme o intérprete e é o conjunto de todas as características comuns a todos os objetos que constituem a extensão de um termo. Por essa característica de abranger a extensão completa de um termo, demonstra-se inviável, já que não se tem conhecimento de todas as palavras neste nível.

É a "conotação consensual" que melhor se adapta à utilização em definições, visto representar a atribuição das mesmas propriedades, pelo mesmo critério, por vários sujeitos, para um mesmo objeto, numa convenção que estabelece um acordo, sendo de dominação pública.

\subsubsection{Definições Denotativas e Conotativas}

As definições, segundo suas técnicas, podem ser "denotativas" e "conotativas"; aquelas são feitas pela enumeração de objetos denotados por determinado termo. Neste sentido, podemos entender a lista de serviços anexa à lei complementar prevista no art. 156, III da CF como uma definição que enumera os objetos denotados como "serviços de qualquer natureza".

A definição conotativa é considerada a mais importante e autêntica maneira de definir um objeto e nos permite definir termos por intermédio de seu gênero e diferença (enquanto espécie).

Não há dúvidas de que o emprego de signos vagos ou ambíguos no desenho constitucional das competências tributárias mostra-se inadequado, podendo trazer como consequência imediata a alteração da dimensão do critério material daqueles tributos, isto para não ingressarmos no campo da insegurança jurídica dos administrados.

Neste contexto, o ideal seria a utilização de palavras cuja significação fosse única, ou que o próprio legislador trouxesse na norma introdutora aquele significado

${ }^{533}$ Cf. COPI, Irving M., op. cit. (nota 519), p.120. 
que entende deva ser empregado, tomando assim a definição o caráter de enunciado prescritivo, já que vincularia a atividade do exegeta e do aplicador do direito.

\subsubsection{3. "Significado de Base" das Palavras}

Já vimos que não se coaduna com a realidade imaginarmos possível ao legislador a construção de enunciados prescritivos utilizando-se de signos que possuam um único conteúdo significativo, conferindo assim segurança tanto à interpretação quanto às relações subjacentes.

Estes enunciados, base para a construção de significados, serão impregnados, nesta tarefa de construção de sentido, pelos valores do exegeta que, por sua vez, são condicionados por seu horizonte cultural. Segundo Aurora T. Carvalho, "todo o conteúdo jurídico depende de valoração e esta se condiciona às vivências do intérprete." 534 E prossegue asseverando a inexistência de um método hermenêutico que conduza o exegeta a um sentido único, devendo prevalecer aquele que convence, seja por sua justificação, ou porque se mostra mais adequado culturalmente àquele momento, ou cujo intérprete possui uma retórica mais apurada, etc. ${ }^{535}$

Parte da doutrina considera a adoção de "significado de base" para cada palavra, que seria aquele sentido mínimo ao qual o intérprete estaria limitado. Toda a sociedade deveria aceitá-lo como conteúdo de significação dos termos, mas não podemos esquecer que, face à vaguidade e possível ambiguidade das palavras, é difícil conseguir tal delimitação.

Esta "significação de base", como o próprio nome indica, é também uma significação, ou seja, um conceito construído na mente do intérprete que o utiliza, e que restará condicionado a todas as suas vivências, valores e referências. Desta forma, não é possível afirmarmos que exista uma interpretação "correta", mas apenas aquelas construídas a partir dos enunciados do direito positivo.

Eurico de Santi entende que as palavras utilizadas nos enunciados do direito positivo possuem um "sentido socialmente estandardizado", que está associado a seu significado contextual, e que irão influenciar a tarefa de atribuir-lhes significação. ${ }^{536} \mathrm{E}$

${ }^{534}$ CARVALHO, Aurora Tomazini de, op. cit. (nota 17), p. 224.

${ }^{535}$ Cf. Idem, ibidem, p. 224.

${ }^{536}$ SANTI, Eurico, Lançamento Tributário, São Paulo, Max Limonad, 2a ed., 2009, p. 144. 
prossegue trazendo as lições de Alf Ross, ensinando que o contexto e a situação irão influenciar no significado preciso de uma palavra.

Neste sentido, Aurora Tomazini brilhantemente elucida que "cada um de nós constrói o direito (enquanto conjunto de significações) que acha mais convincente, coerente, justo, adequado. Mas o direito que prevalece num conflito de interesses é aquele construído (interpretado) pelo judiciário." 537

Naqueles casos em que a significação é dada pelos órgãos aplicadores do direito, que incluem os órgãos judiciais, tem-se a denominada "interpretação autêntica", em que determinado termo é conceituado no texto normativo correspondente, ou cuja significação é delimitada pelo poder judiciário. Na teoria de Hans Kelsen, quando a significação de determinado termo é dada pelos órgãos competentes para a aplicação do direito, tem-se a denominada interpretação autêntica, cujo enunciado normativo possui força vinculante. ${ }^{538}$

\subsubsection{Conceito de "Serviços"}

A análise da hipótese de incidência do Imposto Sobre Serviços deve ter como ponto de partida a compreensão do significado jurídico do signo "serviços", empregado pelo legislador constitucional para definir o critério material do imposto.

A palavra "serviço" assume lexicograficamente mais de 25 significados diversos: (i) ação ou efeito de servir, de dar de si algo em forma de trabalho; (ii) exercício e desempenho de qualquer atividade; (iii) o próprio trabalho a ser executado ou que se executou; a obra, o expediente, o mister, a tarefa, a ocupação ou a função; (iv) estado de quem serve outrem; (v) percentagem de uma conta de hotel, de restaurante etc. que se destina a gratificar o pessoal e a cobrir certas despesas fixas, entre outros. ${ }^{539}$

Por certo que no presente trabalho nos deteremos naqueles significados que possuam conteúdo tributário, que denote riqueza para ensejar o entrelaçamento da relação jurídico-tributária.

Para Aires Barreto, o conceito de "serviço" é pressuposto constitucionalmente, constituindo-se “(n)uma prestação de esforço humano a terceiros,

${ }^{537}$ CARVALHO, Aurora Tomazini de, op. cit. (nota 17), p. 226.

${ }^{538}$ Cf. FERRAZ JUNIOR, Tércio Sampaio, op. cit. (nota 394), pp. 228-230.

${ }^{539}$ Verbete "serviço", HOUAISS, op. cit. (nota 54). Acesso em 13 de janeiro de 2012. 
com conteúdo econômico, em caráter negocial, sob regime de direito privado, tendente à obtenção de um bem material ou imaterial", 540 abrigando o conceito uma "obrigação de fazer". 541

A mencionada tese foi vencedora no leading case de locação de bens móveis, perante o Supremo Tribunal Federal - STF, que reconheceu a inconstitucionalidade da expressão "locação de bens móveis", constante no item 79 da Lista de Serviços anexa ao Decreto Lei no 406/68 (redação da LC n 56/87), entendendo ainda que exista um conceito de "serviços" que não pode ser alterado para fins de tributação, já que em direito os institutos, assim como os vocábulos, têm sentido próprio, de forma que não seria possível confundir a locação de serviços com a de móveis. ${ }^{542}$

A esse julgado seguiram-se inúmeras decisões da Corte Suprema no mesmo sentido, tendo recentemente sido o assunto sumulado, Súmula $\mathrm{n}^{\mathrm{o}} 31$, que tem o seguinte teor: "É inconstitucional a incidência do Imposto sobre Serviços de Qualquer Natureza - ISS sobre operações de locações de móveis".

Nesta esteira, a Lei Complementar $n^{\circ} 116$, que veicula atualmente a Lista de Serviços, teve alguns itens relativos à locação de bens móveis vetados em decorrência da mencionada decisão plenária do STF. ${ }^{543}$

\subsection{A Definição de "Serviços"}

A Lei Complementar $n^{\circ} 116$ de 2003, nos termos do que dispõe o artigo 156, III, da Constituição Federal, cumpre, entre outros, o encargo de "definir" os serviços sobre os quais irá incidir o Imposto sobre Serviços, cuja competência a Magna Carta atribuiu aos Municípios.

Como já abordamos neste trabalho, uma das funções primordiais da definição é eliminar o vício de ambiguidade das palavras; desta forma, o legislador complementar, ao cumprir a determinação constitucional, formulou uma "definição denotativa", enumerando todos os objetos denotados pelo signo "serviço". Por outro giro,

${ }^{540}$ BARRETO, Aires, ISS - Não incidência sobre Cessão de Espaço em Bem Imóvel, Apud MELO, José Eduardo S. e PAULSEN, Leandro, Impostos Federais, Estaduais e Municipais, Livraria do Advogado, Porto Alegre, 2007, p. 283.

${ }^{541} \mathrm{O}$ tema da dicotomia "obrigação de fazer x obrigação de dar" será abordado no item 5.9 deste trabalho.

${ }^{542}$ RE 116.121/SP, Supremo Tribunal Federal, Rel. Min. Otávio Gallotti, DJ, de 25.05.2001.

${ }^{543}$ Razões do veto disponível em: <http://www.planalto.gov.br/ccivil_03/Leis/Mensagem_Veto/2003/Mv362-

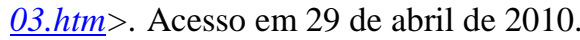


trata-se a lista de serviços anexa à lei complementar prevista no art. 156, III da CF de uma definição que enumera os objetos caracterizados como "serviços de qualquer natureza".

Neste sentido, a lista de serviços anexa à lei complementar contempla 40 itens, subdivididos em vários subitens, referindo-se a mais de 500 serviços, sendo considerada pela doutrina como taxativa.

A interpretação de uma lista como taxativa ou exemplificativa se justifica algumas vezes pela declaração contida no próprio texto normativo e noutros casos resulta de construção doutrinária ou jurisprudencial. No primeiro caso, resta ao intérprete dúvida somente em relação à sua interpretação horizontal, ou seja, "sobre a extensão de cada fato descrito abstratamente". 544

A Lista de Serviços do ISS é um exemplo de taxatividade resultante de construção jurisprudencial; o entendimento pacífico do Superior Tribunal de Justiça - STJ, é no sentido de que a lista de serviços é taxativa, mas admite interpretação extensiva. Vale dizer, estariam definidos na lei complementar os "gêneros" de serviços compreendidos na competência dos municípios, sendo admitida sua aplicação a outras espécies de serviços, congêneres ou correlatos. Esta interpretação extensiva da Lista de Serviços, para além de permitida é necessária, como bem salientou a Min. Eliana Calmon no REsp 325.344-PR, que caso contrário seria possível pela simples mudança de nomenclatura de um serviço, a incidência ou não do ISS. ${ }^{545}$

Para Roque Carrazza, a lista é "apenas sugestiva e, por isso mesmo, perfeitamente dispensável, tanto pelo legislador municipal quanto pelo juiz e pelo administrado público. Melhor esclarecendo, ela contém sugestões que poderão, ou não, ser levadas em conta pela Câmara de Vereadores de cada Município ao instituir, in abstracto, o ISS". 546

No entanto, mesmo após a edição da referida norma, muitos contribuintes cujas atividades empresariais foram contempladas na mencionada lista, continuam a recorrer ao Judiciário visando a obter o reconhecimento da não incidência do imposto sobre suas atividades. Apoiam-se, de regra, na doutrina que apregoa ser a prestação de serviços uma "obrigação de fazer" e não "obrigação de dar", limitando o campo de incidência do ISS apenas àqueles contratos que contenham aquelas obrigações, e que

544 ANDRADE, José Maria Arruda de, Interpretação da Norma Tributária, São Paulo, MP Editores, 2006, p.223.

${ }^{545}$ Cf. RE. 325.344/PR, Relatora Min. Eliana Calmon, DJ 08.09.2003.

${ }^{546}$ CARRAZZA, Roque, op. cit. (nota 326), p. 961. 
guardariam perfeita harmonia com o critério material do tipo tributário do imposto, qual seja, prestar + serviço.

Neste diapasão, entendemos que a Lei Complementar, ao desempenhar o papel que lhe atribuiu a Constituição Federal no art. 156, ao invés de elencar as atividades sobre os quais incide o Imposto sobre Serviços, deveria elucidar a real abrangência da expressão utilizada pelo constituinte originário.

Além disto, a Constituição Federal, ao definir a materialidade do ISS, adjetivou o signo "serviços", agregando a expressão "de qualquer natureza", cujo alcance se discute na doutrina. Se considerarmos que a Lei não possui expressões inúteis, forçoso admitir que o predicado "de qualquer natureza" possui significado determinado.

\subsection{A Revisão do Conceito de "Serviço" no STF: "Serviços de Qualquer Natureza"}

O Direito Positivo, que também exibe um aspecto falível, necessita, por vezes, que outra norma, introduzida por uma decisão judicial, sobreponha-se àquela geral e abstrata, para complementar ou elucidar a previsão genérica. Tal decisão provém de questionamentos concretos e as decisões proferidas frequentemente prestigiam valores políticos. Como resultado de tal sistemática, pode ocorrer "a reformulação ou a proposta de novas definições, considerando a possibilidade de falhas ou desvios dos critérios previamente estabelecidos para o estabelecimento das relações jurídicas". 547

O Superior Tribunal de Justiça vinha esposando entendimento de que a Constituição Federal alberga um conceito pressuposto de "prestação de serviço", que se revela numa obrigação “de fazer", que não se confunde com aquela "de dar". 548

No entanto, o conceito de serviços foi novamente analisado perante o Supremo Tribunal Federal, em duas ações em que se discutia a constitucionalidade, ou não, da incidência do Imposto sobre Serviços de qualquer Natureza - ISS sobre operações de arrendamento mercantil (leasing). O Tribunal deu provimento ao RE 547245/SC, interposto pelo Município de Itajaí, e negou-se provimento ao RE 592905/SC, interposto por instituição financeira, ambos de relatoria do Ministro Eros Grau, cujo voto foi

${ }^{547}$ ARAUJO, Clarice Von Oertzen, op. cit. (nota 23), p. 16.

${ }^{548}$ Cf. AgRg no RE no 953.840-RJ, STJ, Relator Min. Luiz Fux, 20.08.2009. 
acompanhado por outros nove ministros. O fulcro da análise era o contrato de leasing como contrato autônomo e que, "embora resulte da fusão de elementos de outros contratos, não pode ser considerado como contrato misto, composto por prestações típicas da locação, da compra e de outros contratos, porque tem causa própria e já se tipicizou". 549

O Supremo decidiu no Recurso Extraordinário no 592.905/SC que o arrendamento mercantil classifica-se em três modalidades: (i) o leasing operacional, (ii) o leasing financeiro e (iii) o leasing back. "No primeiro caso, há locação; nos outros dois, serviço". A conclusão do Relator Min. Eros Grau é que a principal atividade praticada no arrendamento mercantil é a de financiamento, que constitui um serviço sobre o qual pode incidir o ISS. ${ }^{550}$

No mencionado julgamento, o relator, acolhendo parecer do Min. Ilmar Galvão sobre a natureza dos serviços compreendidos na expressão constitucional "serviços de qualquer natureza", definiu sua extensão. Segundo o relator, a Lei Complementar mencionada pela CF no artigo 156, III arrola (i) serviços por natureza; (ii) inclui serviços que, não exprimindo a natureza de outro tipo de atividade, passam à categoria de serviços, para fins de incidência do tributo, por força de lei, visto que, se assim não considerados, restariam incólumes a qualquer tributo; e (iii) em caso de operações mistas, afirma a prevalência do serviço, para fins de tributação pelo ISS. Ainda segundo o mencionado parecer,

são serviços assim conceituados por força da própria lei, configurando atividades que, em si mesmas, não revestem essa natureza, mas que, também, não exprimem, rigorosamente, a natureza de outro tipo de atividade diferentemente tributada [...] que ficariam a cobro de qualquer exação fiscal. ${ }^{551}$

Segundo o relator, "a lei complementar não define o que é serviço, apenas o declara, para os fins do inciso III do artigo 156 da Constituição. Não o inventa, simplesmente descobre o que é serviço para os efeitos do inciso III do artigo 156 da Constituição". 552

${ }^{549}$ Cf. RE 547.245/SC. Tribunal Pleno, STF, Rel. Min. Eros Grau, DJ 02.12.2009.

${ }^{550}$ Cf. ÁVILA, Humberto, Imposto sobre a Prestação de Serviços de Qualquer Natureza. Contrato de Leasing Financeiro. Decisão do Supremo Tribunal Federal. Local da Prestação e Base de Cálculo, Revista de Dialética de Direito Tributário n ${ }^{\circ} 182$, p. 134.

${ }_{551}^{55}$ Trecho do Parecer do Min. Ilmar Galvão no RE 547.245/SC, Relator Min. Eros Grau.

${ }^{552}$ Trecho do acórdão do RE 592.905/SC, Relator Min. Eros Grau. 
Roque Carrazza, referindo à lista de serviços do ISS, já há muito advertira para o fato de que "a lei complementar não pode prever "serviços por definição legal", tributáveis pelo ISS", ${ }^{553}$ Agindo desta forma, estaria ferindo, dentre outros, o direito subjetivo do contribuinte de ser tributado nos estritos ditames constitucionais, padecendo, portanto, a referida lei complementar, de inconstitucionalidade material, por "dilatar as competências tributárias municipais". 554

Para José Eduardo Soares de Melo, a Constituição Federal não conceituou "serviço" para fins de incidência do ISS, devendo o conceito ser extraído pela interpretação conjunta das materialidades de todos os impostos ali previstos. Desta forma, o campo de incidência do tributo municipal não pode sobrepor-se àquele do IPI, que também consiste num "fazer", nem do ICMS, que abriga obrigações de "dar". 555

No julgamento do RE 547.245/SC, concluiu o relator Ministro Eros Grau que a competência para tributar serviços de qualquer natureza (artigo 156, III da Constituição) não consubstancia típica obrigação de fazer, à luz da expressão constitucional "de qualquer natureza", ou se estaria desprezando a adjetivação contida no texto constitucional. Além disto, salientou que "toda obrigação de dar consubstancia também um fazer e há inúmeras obrigações de fazer que envolvem um dar". ${ }^{556}$ No que tange à lei complementar, esta não conceitua o que é serviço, mas apenas define, delimita o termo para efeitos do previsto no inciso III do artigo 156 da Constituição.

No mesmo recurso, o Min. Joaquim Barbosa proferiu voto em que foi além, afirmando que "não há um conceito constitucional absoluto, imutável, intuitivo através dos tempos para serviços, ditado pela ordem natural e que possa ser a priori violado por conceitos criados pela função especulativa a que aludiu Irving Copi." 557 Segundo ele, "não impressiona a argumentação no sentido de que haveria um conceito inequívoco para a expressão serviços de qualquer natureza" ${ }^{558}$ e que o conceito provém do direito civil, tendo com o passar do tempo sido temperado pelo uso e aceitação. E, citando Umberto Eco, lembrou de que as palavras possuem uma significação de base, concluindo com Alf Ross que todas elas são vagas, e muitas são ambíguas.

\footnotetext{
${ }^{553}$ CARRAZZA, Roque, op. cit. (nota 326), p. 961.

${ }^{554}$ Cf. Idem, ibidem, p. 962.

${ }^{555}$ BARRETO, Aires F., op. cit. (nota 540), p. 282.

${ }^{556}$ Trecho do acórdão do RE 592.905/SC, Relator Mini. Eros Grau.

557 Trecho do voto do Min. Joaquim Barbosa no RE 547.245/SC, Relator Min. Eros Grau.

${ }^{558}$ Idem, ibidem.
} 
O julgamento analisou ainda do art. 110 do $\mathrm{CTN}$; no teor da referida norma, a definição, o conteúdo e o alcance de institutos, conceitos e formas de direito privado não podem ser alterados pela lei tributária para definir ou limitar competências tributárias, quando forem utilizados pela Constituição Federal, Constituições Estaduais ou mesmo pela Lei Orgânica de Municípios e do Distrito Federal. Segundo o Min. Barbosa, o artigo é redundante ao dispor que os conceitos utilizados pela Constituição não podem ser violados pela legislação infraconstitucional.

Conclui o Ministro aduzindo que os conceitos jurídicos, mesmo que arraigados, devem, em função da evolução social, ser reavaliados, ainda que para confirmá-los, citando a clássica divisão das obrigações em "dar" e "fazer", que hoje desafiam a caracterização de determinadas operações cujo contrato é complexo e, ainda que composto por diversos elementos, não se caracteriza pela simples soma de suas partes, e que possuem regime jurídico próprio.

Ainda no mesmo recurso, o Min. Cezar Peluso em seu voto aponta que teria ocorrido até o momento por parte daquele órgão um erro de perspectiva ao tentar interpretar instrumentos, institutos e figuras jurídicos que regulam atividades complexas da economia do mundo atual por meio da aplicação de concepções adequadas àquela simplicidade do mundo do império romano, cujos contratos típicos continham obrigações explicáveis pela distinção escolástica entre obrigação de dar, fazer e não fazer. ${ }^{559}$

Assim, o Supremo Tribunal Federal analisando a figura do leasing promoveu a quebra de diversos paradigmas consubstanciados no RE 592.905, relativamente à definição de "serviços de qualquer natureza" para fins de incidência do ISS, o que pode significar um divisor de águas no que tange à avaliação da matéria pelo Judiciário.

Recentemente, o STJ confirmou a incidência do ISS sobre o franchising, considerando tratar-se de "serviço", tendo como razão de decidir o fato de estar expressamente previsto no item 17.08 da Lista de Serviços anexa à LC 116. No AgReg no REsp n ${ }^{\circ} 1.191 .839,2^{\text {a }}$ Turma do STJ, validou-se a cobrança do ISS sobre uma famosa rede de franquia, restando assim ementado o recurso:

AgRg no RECURSO ESPECIAL No 1.191 .839 - DF (2010/0081278-0) TRIBUTÁRIO E PROCESSUAL CIVIL. ISS. LC N $\mathrm{N}^{\mathrm{o}} 116 / 2003$.

\footnotetext{
${ }^{559}$ Trecho do voto do Min. Cezar Peluso no RE 547.245/SC, Relator Min. Eros Grau.
} 
CONTRATO DE FRANQUIA. INCIDÊNCIA TRIBUTÁRIA. PREVISÃO EXPRESSA.

1. Com a edição da Lei Complementar $n^{\circ} 11603$, em vigor a partir de 01.01.2004, a operação de franquia passou a ser expressamente prevista no item 17.08 da lista de serviços anexa à norma, ficando, portanto, sujeita à incidência tributária. Precedentes: AgRg no REsp 982.171/RJ, Rel. Min. Mauro Campbell Marques, Segunda Turma, DJe 29.04.10; $\mathrm{AgRg}$ no REsp 1.151.492SP, Rel. Min. Mauro Campbell Marques, Segunda Turma, DJe 10.03.2011; AgRg no REsp 1.140.028MG, Rel. Min. Humberto Martins, Segunda Turma, DJe 14.02.2011; EDcl no REsp 1.066.071/SP, Rel. Min. Teori Albino Zavascki, Primeira Turma, DJe 05.03.2010.

2. Agravo regimental provido.

Como se pode depreender, o argumento aduzido por aquela Corte resume-se no fato de estar o serviço expressamente previsto na Lei Complementar, tendo o tema já sido apreciado pela Segunda Turma, oportunidade em que se ressaltou a inclusão do franchising, de forma geral, no campo de incidência do ISSQN, após a vigência da Lei Complementar $116 / 2003$.

Segundo o Ministro relator Castro Meira, a legislação anterior que regia a matéria, Decreto-lei n $n^{o} 406 / 68$ e Lei Complementar $n^{\circ}$ 56/87, não contemplava o franchising no rol de serviços sujeitos à tributação pelo ISS. Com a edição da Lei Complementar $n^{\circ} 116 / 2003$, no entanto, o item passou a estar expressamente previsto na lista de serviços, concluindo que "o assunto não comporta maiores digressões no âmbito desta Corte de Justiça, a quem cabe zelar pelo cumprimento da legislação infraconstitucional". 560

\subsection{Os Conceitos Constitucionais perante o Supremo Tribunal Federal}

A questão da existência de "conceitos constitucionais", assim como a definição e conteúdo de institutos jurídicos consagrados têm sido objeto de análise por nossos Tribunais Superiores, instados a fixar uma interpretação homogênea para diversos signos que compõem as normas de nosso sistema, em especial aquelas que delimitam a competência tributária das pessoas políticas.

Inúmeras vezes o Supremo Tribunal Federal - STF analisou tais situações, vislumbrando Paulo A. Barreto clara tendência no reconhecimento da existência

\footnotetext{
${ }^{560}$ Trecho do voto do Relator Min. Castro Meira no AgRg no RECURSO ESPECIAL No 1.191.839 - DF.
} 
no texto constitucional de conceitos determinados. ${ }^{561} \mathrm{E}$ aduz vários exemplos em que aquele órgão reconheceu a existência destes conceitos: (i) quando excluiu a locação de bens móveis do campo de incidência do ISS (RE 116.121-3 SP); (ii) na análise da incidência do ICMS nas importações realizadas por pessoas físicas (RE 185.789/SP); (iii) na fixação da incidência da contribuição previdenciária nos pagamentos a avulsos, autônomos e administradores (RE 177.296-4/RS); e (iv) na determinação da base de cálculo da COFINS (RE 346.084-6/PR). ${ }^{562}$

Neste último caso, no entanto, não parece ter aquela Corte reconhecido que há tal conceito constitucional. Na ocasião, o STF debruçou-se sobre o signo "faturamento", inserto na regra matriz das Contribuições para o Financiamento da Seguridade Social - COFINS e para o PIS/PASEP, perquirindo a existência de um "conceito constitucional" e definindo o papel do legislador infraconstitucional neste encargo.

Em síntese, manifestou aquela Corte entendimento no sentido de que, ainda que não exista um conceito constitucional para "faturamento", a lei infraconstitucional havia promovido o alargamento do conceito de "faturamento". O acórdão restou assim ementado:

CONSTITUCIONALIDADE SUPERVENIENTE - ARTIGO $\underline{3}^{\circ}, \S 1^{\circ}$, DA LEI N ${ }^{\circ}$ 9.718, DE 27 DE NOVEMBRO DE 1998 - EMENDA CONSTITUCIONAL $\mathrm{N}^{\circ} \underline{20}$, DE 15 DE DEZEMBRO DE 1998. O sistema jurídico brasileiro não contempla a figura da constitucionalidade superveniente. TRIBUTÁRIO - INSTITUTOS - EXPRESSÕES E VOCÁBULOS - SENTIDO. A norma pedagógica do artigo 110 do Código Tributário Nacional ressalta a impossibilidade de a lei tributária alterar a definição, o conteúdo e o alcance de consagrados institutos, conceitos e formas de direito privado utilizados expressa ou implicitamente. Sobrepõe-se ao aspecto formal o princípio da realidade, considerados os elementos tributários. CONTRIBUIÇÃO SOCIAL - PIS - RECEITA BRUTA - NOÇÃO - INCONSTITUCIONALIDADE DO § $1^{\circ}$ DO ARTIGO $3^{\circ}$ DA LEI No 9.718/98. A jurisprudência do Supremo, ante a redação do artigo 195 da Carta Federal anterior à Emenda Constitucional $n^{\circ} 20 / 98$, consolidou-se no sentido de tomar as expressões receita bruta e faturamento como sinônimas, jungindo-as à venda de mercadorias, de serviços ou de mercadorias e serviços. É inconstitucional o $\S 1^{\circ}$ do artigo $3^{\circ}$ da Lei $n^{\circ} 9.718 / 98$, no que ampliou o conceito de receita bruta para envolver a totalidade das receitas auferidas por pessoas

${ }_{561}^{561}$ Cf. BARRETO, Paulo A., op. cit. (nota 450), p. 79.

${ }^{562}$ Cf. Idem, ibidem, pp. 80-81. 
jurídicas, independentemente da atividade por elas desenvolvida e da classificação contábil adotada. (g.n.) ${ }^{563}$

Naquele recurso, o Ministro Gilmar Mendes, em voto-vista, considerando precedentes daquela Corte, afirmou que o órgão "rejeitou qualquer tentativa de constitucionalizar eventuais pré-concepções doutrinárias não incorporadas expressamente no texto constitucional. O STF jamais disse que havia um específico conceito constitucional de faturamento". E ainda, "ao contrário, reconheceu que ao legislador caberia fixar tal conceito". 564

Prosseguiu o Ministro admitindo a existência de "normas constitucionais abertas" às quais entende legítima a vinculação de conteúdos, considerando que não se pode "eternizar um específico conteúdo em detrimento de todos os outros sentidos compatíveis". Reafirmou então as necessidades de atualização e adaptação do texto constitucional à realidade, já que uma decisão é sempre adotada em uma circunstância específica "que pode não representar a melhor via de concretização do texto constitucional." Rejeitou, destarte, "qualquer tentativa de incorporar ao Texto Constitucional, de modo definitivo ou exclusivo, aquela definição de faturamento adotada em 1991, ou de qualquer conceito ou legislativo de faturamento". 565

Haveria no Direito Constitucional, segundo o Ministro, um plexo de normas garantidoras de realidades institucionais, para as quais não existe uma definição de seus limites no próprio texto constitucional, como, por exemplo, propriedade, liberdade, família, consumidor e, no âmbito tributário, traz como exemplos os conceitos de renda, confisco, grande fortuna, etc. ${ }^{566}$

Finaliza então seu voto negando qualquer interpretação que retire do legislador ordinário o que denomina "poder de conformação", alertando, no entanto, para o caráter vinculado dessa atividade, que é limitada e subordinada a todas as demais normas que compõem o sistema constitucional.

Paulo A. Barreto rechaça tal posição, embasado na premissa de que as normas delimitadoras das competências não possuem um caráter aberto, já que admitir tal ideia significaria um esforço em vão do constituinte, que teria repartido, sem nada

\footnotetext{
${ }^{563}$ Trecho do voto do Relator Ilmar Galvão no RE 346.084/PR, DJ 08.11.2005.

${ }^{564}$ Trecho do voto-vista do Min. Gilmar Mendes no RE 346.084/PR, Relator Ilmar Galvão, DJ 08.11.2005, p. 26.

${ }^{565}$ Idem, ibidem, p. 27.

${ }^{566}$ Idem, ibidem, p. 28.
} 
discriminar, correndo-se ainda o risco de esvaziar o conteúdo, sentido e alcance de tais normas. E aduz que o exercício da competência tributária "foi limitado constitucionalmente e deve obedecer ao conjunto de "regras" que, por intermédio da fixação de conceitos determinados, delimitou o espaço de atuação legiferante dos entes tributantes para a criação de tributos". 567

No entanto, foi no mesmo sentido o voto do Ministro Cezar Peluso naquele Recurso Extraordinário, que enfaticamente reafirma que a Constituição Federal não define uma série de institutos dos quais se utiliza e que, portanto, não há no texto constitucional conceitos formais ou pré-definidos. Acrescenta ainda, que não seria mesmo conveniente que o Texto Maior trouxesse tais conceitos, visto que deve adaptar-se "às necessidades históricas da evolução socioeconômica, segundo sua vocação de abertura permanente". Seria, então, essa flexibilidade constitucional necessária para que as mutações culturais pudessem ser refletidas naquele texto sem que se promovessem inúmeras alterações. ${ }^{568}$

E menciona Peluso o célebre exemplo dos conceitos jurídicos de "cidadão" e "propriedade" nos Estados Unidos sobre a evolução dos conceitos constitucionais em face das mutações sociais:

No famoso caso DRED SCOTT v SANDFORD (1857), a Suprema Corte norte-americana decidiu que o autor não era "cidadão" por ser escravo. Como escravo, era objeto de propriedade e, pois, não era titular de nenhum dos direitos reconhecidos aos cidadãos norte-americanos, entre os quais o de acesso ao Judiciário. Apesar da subsistência léxica do texto constitucional norte-americano, tal decisão seria hoje inadmissível segundo o espírito do tempo. ${ }^{569}$

Em que pesem as diferenças históricas, culturais e políticas entre os Estados Unidos e o Brasil, seria desejável que a Carta Magna de um país prescindisse de constantes alterações para livrá-la dos anacronismos causados pelas mutações sociais. A ideia de uma Constituição que subsiste à evolução social, em que se atribui às normas infraconstitucionais o papel de complementá-la, dentro do contexto construído e vivenciado pela sociedade, pode ser admitida quando se toma a posição tipológica,

\footnotetext{
${ }^{567}$ BARRETO, Paulo A., op. cit. (nota 450), p. 83.

${ }^{568}$ Trecho do voto-vista do Min. Cezar Peluso no RE 346.084/PR, Relator Ilmar Galvão, DJ 08.11.2005, p. 48.

${ }^{569}$ Idem, ibidem, p.47.
} 
entendendo que se utilizou o legislador constituinte de tipos e não conceitos para a atribuição das competências tributárias.

Ainda segundo o Ministro Cezar Peluso, no referido voto do RE 346.084/PR, o termo (signo linguístico) é estipulado pelos usuários de forma arbitrária e consensual, construído em torno de um código implícito de uso, e que, portanto, não decorre da natureza do próprio objeto. Prossegue reconhecendo a vaguidade ínsita às palavras, mas salienta que há um limite de resistência e que existe um "conteúdo semântico mínimo recognoscível a cada vocábulo”. E cita Umberto Eco, que ensina que o intérprete não pode atribuir qualquer significado a uma mensagem, já que alguns sentidos seriam despropositados de se sugerir. ${ }^{570}$

Para Eco, a realidade seria algo social, antes de ser individual. Isto significa dizer que quando um homem habita uma língua ela "projeta um horizonte categorial de significação em que se articulam uma forma de vida cultural e a précompreensão do mundo" 571

Desta forma, o mundo em que o homem está situado possui uma realidade das coisas que nada mais é do que uma interpretação, condicionada por uma tradição linguística deste contexto social. Desta forma, existem "expectativas de sentido" que nos são repassadas por nossa tradição específica, que tornam possível nossa compreensão de algo. Vale dizer, há um horizonte de significações que habitam o sujeito cognoscente, a partir do qual ele tece suas interpretações; dizer que algo tem uma significação diferente do contido naquele horizonte é que seria "despropositado", como afirmou no voto o Ministro Cezar Peluso.

Este "horizonte" compõe o denominado "sistema de referência" de uma determinada sociedade, já que todo ato de conhecer só se estabelece por meio de relações associativas, condicionadas pelo horizonte cultural do sujeito cognoscente e determinadas pelas coordenadas de tempo e espaço em que são processadas. Aurora Tomazini denomina sistema de referência àquelas "condições que informam o conhecimento sobre algo". 572

Quanto à possibilidade de evolução dos conceitos, Paulo A. Barreto entende que é "natural e até desejável que um sistema jurídico seja dotado de certa margem de flexibilidade e, portanto, adaptável e atualizável." Tanto assim que o próprio texto

${ }^{570}$ ECO, Humberto, Interpretação e Superinterpretação, Apud voto Min. Cezar Peluso, RE 346.084/PR, Relator Ilmar Galvão, 8.11.2005, p. 49.

${ }^{571}$ HABERMAS, Jurgen ,Verdade e justificação, Apud CARVALHO, Aurora T., op. cit. (nota 17), p. 19.

${ }^{572}$ CARVALHO, Aurora Tomazini de, ibidem, p. 21. 
constitucional prevê seus mecanismos de alteração, não havendo que se falar em “eternização de conceitos”, exceto quanto àquele núcleo imutável (cláusulas pétreas). ${ }^{573}$

Assim, equaciona o pensamento do legislador constitucional da seguinte maneira: (i) nas situações em que não há a necessidade de regramento específico, utilizouse o constituinte de "princípios"; (II) nas hipóteses em que tal nível de abstração poderia induzir a problemas, estipulou "regras claras"; (iii) isolou e definiu um "núcleo imutável” e (iv) estabeleceu os procedimentos que devem ser adotados para a alteração dos demais comandos normativos. ${ }^{574}$

Cezar Peluso, no voto do RE 346.084-6, salienta ainda a possibilidade de o legislador construir significados específicos nos próprios textos normativos que cria, afastando desta forma as ambiguidades, como, por exemplo, o art. $3^{\circ}$ do Código Tributário Nacional que definiu "tributo". De acordo como o Ministro, na grande maioria dos casos, o significado de um signo é traduzido pelo próprio contexto em que está inserido, nos mais variados campos. 575

Do ponto de vista semântico, uma palavra possui tantos significados quantos sejam os contextos em que for inserida. É que "o contexto tem importância crucial na determinação do significado e da significação das palavras. A palavra [...] não existe senão pelo contexto". 576

Trazendo então como exemplo de estratégia normativa válida, Cezar Peluso cita o art. 327 do Código Penal, que adjudica uma definição de "funcionário público" especificamente para fins penais, salientando que pode o legislador atribuir novo significado a um antigo termo.

Caberia, assim, às definições legais a especificação daqueles termos contidos nas normas e sobre os quais existem dúvidas relativas à significação, orientando então sua aplicação ${ }^{577}$, assumindo, portanto, feição prescritiva, já que determina a atividade do intérprete e do destinatário da norma. Tácio Lacerda Gama, no entanto, apoiando-se na doutrina de Bulygin e Alchourrón, entende que a definição legal não se confunde com a

\footnotetext{
${ }^{573}$ Cf. BARRETO, Paulo A., op. cit. (nota 450), p. 83.

${ }^{574}$ Cf. Idem, ibidem, p. 84.

${ }^{575}$ Trecho do voto-vista do Min. Cezar Peluso no RE 346.084/PR, Relator Ilmar Galvão, 08.11.2005, p.48.

${ }^{576}$ SANTI, Eurico, op. cit. (nota 536), p. 143.

${ }^{577}$ Cf. GAMA, Tácio Lacerda, op. cit. (nota 21), p. 33.
} 
norma, já que, ainda que lhe traga maior precisão de sentido, possui formas diversas de empregar as palavras e tem finalidades distintas. ${ }^{578}$

As definições legais podem ter como finalidades: “(i) dar maior precisão a um termo, restringindo seu alcance (...); (ii) ampliar o alcance de um termo para incluir nele situações que não estão claramente cobertas por seu sentido (...); (iii) introduzir um termo novo, que não é usual na linguagem comum." 579 Já as normas, em geral, regulam condutas intersubjetivas, declarando-as como obrigatórias, permitidas ou proibidas.

\subsection{Construção de sentido a partir de conceitos constitucionais e as novas realidades}

$$
\text { Partindo-se do pressuposto da inexistência de "conceitos }
$$
constitucionais", diversos são os caminhos para a construção da significação daquelas referências contidas no texto constitucional. Procurar por um conceito ou significação valendo-se de dicionários poderia ser o primeiro caminho, mas não quando se pretende a significação jurídica de determinado signo utilizado no texto constitucional, principalmente aqueles relativos à atribuição de competência tributária. Neste sentido, Paulo A. Barreto leciona que

Os signos constitucionais, qualificadores do limite para o exercício da competência tributária, devem ser considerados de acordo com sua acepção de base. Deve prevalecer seu sentido técnico-jurídico preexistente. Como ensina Ricardo Guastini, significações específicas no discurso jurídico devem ser obtidas a partir dos textos normativos ou do uso de juristas, e não dos dicionários. ${ }^{580}$

É que o termo estará impregnado pelo contexto em que foi inserido, devendo seu significado ser perquirido considerando-se todo o sistema normativo consignado. Paulo A. Barreto entende que, apenas no caso da ocorrência de uma nova

578 Cf. ALCHOURRÓN, Carlos E.; BULYGIN, Eugenio. Introducción a la metodologia de las ciencias jurídicas $\quad y \quad$ sociales. $\quad$ Disponível <http://www.cervantesvirtual.com/servlet/SirveObras/45707392103492762565679/p0000001.htm\#I_4>. Acesso em 23 de maio de 2012. No original: "Enunciados que no son normativos, pero que influyen en los efectos normativos de otros enunciados. Si bien ellos mismos no son normas, tales enunciados tienen relevancia normativa en conexión con otras normas y son jurídicos en tanto en cuanto integran [107] un sistema jurídico. El ejemplo más importante lo constituyen las definiciones o postulados de significación".

${ }^{579}$ GAMA, Tácio Lacerda, op. cit. (nota 21), p. 33.

${ }^{580}$ BARRETO, Paulo A., op. cit. (nota 450), p. 76. 
ordem constitucional, caberia verificar se os conceitos nela referidos mantiveram o conteúdo semântico preexistente ou se existem fundamentos para sua não-incorporação e consequente transformação. ${ }^{581}$

Ou seja, para aquele mestre, apenas a adoção de uma nova Constituição justificaria a revisão dos conceitos relativos às referências sígnicas ali contidas, perquirindo se houve recepção dos significados preexistentes ou se foi autorizada sua alteração. Citando Andrei Pitten Velloso, conclui que a adoção de conceitos autônomos não pode ser presumida, já que a regra, segundo o "uso comum", é a incorporação dos conceitos preexistentes. A adoção destes poderia ser confirmada sistematicamente no próprio texto constitucional, ao passo que a adoção dos conceitos autônomos deve ser robustamente justificada.

Esta alteração ocorreria, então, pela positivação do conceito no próprio texto constitucional, ou pela construção de um, extraído sistematicamente. Desta forma, não seria o legislador infraconstitucional livre em sua atuação para fixar os conceitos referidos constitucionalmente, já que tal atividade é delimitada por todas as prescrições constitucionais atinentes à matéria. E, como a atribuição de competências tributárias deu-se mediante conceitos determinados e regras precisas, a atuação do legislador infraconstitucional estaria ali delimitada, cabendo-lhe a construção de um novo conceito apenas quando o texto constitucional assim dispuser.

O assunto foi analisado pelo Ministro Joaquim Barbosa no RE 547.245, que analisou a incidência do ISS sobre as operações de leasing. Um dos argumentos aduzidos no referido julgado é que quando a Constituição não define os conceitos que utiliza, deve-se presumir que são válidos aqueles preexistentes na legislação infraconstitucional. Para aquele ministro, não se pode aceitar que haveria uma “interpretação conforme a legislação ordinária", ainda que ela contivesse um conceito universal e inequívoco para prestação de serviços de qualquer natureza. E adverte que o alcance do texto constitucional não poderia ser condicionado por normas infraconstitucionais, sob pena de admitirmos uma "estabilização com força constitucional da legislação infraconstitucional", significando uma confusão entre os planos normativos. 582

${ }^{581}$ Cf. BARRETO, Paulo A., op. cit. (nota 450), p. 77.

${ }^{582}$ Trecho do voto-vista do Min. Joaquim Barbosa no RE 547.245, Relator Min. Eros Grau. 
Admitir que os signos constitucionais possuam uma acepção de base, conforme leciona Paulo Ayres Barreto, significa admitir a possibilidade de evolução destes conceitos, já que, conforme abordamos no presente estudo, esta significação de base é condicionada pelas vivências, valores e referências do próprio intérprete. ${ }^{583}$

Atribuir ao nosso texto constitucional uma rigidez excessiva, não admitindo que os signos ali contidos possam incorporar mutações sociais, tem raízes culturais na história política de nosso país, em especial no período da ditadura militar. Naquela época, por meio da edição de meros Atos Complementares do Presidente da República, tipificou-se como crime a atividade ou manifestação sobre assunto de natureza política, extirpou-se a autonomia de vários municípios considerados de interesse nacional com a imposição de interventores, entre outras medidas autoritárias. ${ }^{584}$

A velocidade inerente à evolução tecnológica nos impõe a adoção de mecanismos hermenêuticos que permitam incorporar realidades até então inéditas àqueles enunciados pré-ordenados no texto constitucional, como é o caso do comércio eletrônico. Como salienta Daniela Braghetta, torna-se evidente a presença de uma realidade, acompanhada de uma nova linguagem caracterizada por bits, que deve ser compatibilizada com aquelas já existentes, assim como ocorreu com a linguagem das telecomunicações que permitem a conexão à Internet. ${ }^{585}$

O termo bit, na teoria da comunicação, significa a unidade de medida da quantidade de informação e representa a expressão binary digit, que são os dois estados possíveis que representam os dados nos sistemas de informação mecânica e eletrônica. ${ }^{586}$

Esta linguagem permite atualmente que qualquer texto, música, voz ou imagem possa, por meio de um processo de digitalização, ser convertido em uma sequência de números, composta somente por dois sinais possíveis, representados pelos algarismos 0 e 1 . Uma vez convertidas, as informações podem ser enviadas à velocidade da luz para qualquer lugar no mundo, onde um beneficiário pode converter as informações de volta em seu formato original ou manipulá-las. Atrelada a esta tecnologia, desenvolveu-se uma forma de comércio que tem como veículo os meios eletrônicos e digitais.

${ }^{583}$ Neste sentido, remetemos o leitor ao tópico 5.3.1.3 do presente trabalho.

${ }^{584}$ O Ato Complementar $n^{\circ} 01$, de 18 de janeiro de 1967 tipificou como crime a conduta de atividade ou manifestação sobre assunto de natureza política. Disponível em: <http://www2.camara.gov.br/legin/fed/atocom/1960-1969/atocomplementar-1-27-outubro-1965-351177publicacaooriginal-1-pe.html>. Acesso em 20 de julho de 2011.

${ }^{585}$ Cf. BRAGHETTA, Daniela de Andrade, op. cit. (nota 87), p. 102.

${ }^{586}$ Cf. ARAUJO, Clarice Oertzen, op. cit. (nota 23), nota ${ }^{\circ} 16$, p. 141. 
Trata-se de uma linguagem formalizada que, na teoria da comunicação, é considerada como códigos artificiais que derivam da linguagem natural e que servem a diversas e distintas finalidades científicas e técnicas. Mas esta linguagem possibilitou que a Internet se constitua hoje em um outro ambiente de concretização de operações mercantis, além daquele físico a que nos habituamos.

Ainda que nossa Constituição Federal não faça qualquer referência explícita ao "comércio eletrônico", não há óbices nem impedimentos para que os fatos jurídicos inerentes a tais operações, oriundas desta nova relação mercantil, sejam tributados pelos entes, conforme predefinido. Isto porque não se pode admitir uma visão estática das coisas, devendo os conceitos ser adaptados à realidade que se transforma dinamicamente. ${ }^{587}$

Os signos, assim como a realidade, são mutáveis e estão constantemente se adaptando para se adequarem ao "novo". É neste sentido a lição de J. L. Austin, de que, ainda que se deva admitir que determinadas palavras são de fato utilizadas em um sentido determinado, desvendar-lhes o sentido não significa que este seja imutável, que não possa ser interpretado ou entendido de maneiras diversas. ${ }^{588}$

No entanto, para Marco Aurélio Greco, os conceitos clássicos utilizados pelo direito tributário estariam em "crise" e seriam insuficientes para abarcar as novas realidades do "comércio eletrônico" e "não estariam preparados para captar adequadamente, em termos tributários, estas novas maneiras pelas quais vão se viabilizar atos denotadores de capacidade contributiva". 589

\subsubsection{Mercadoria $x$ Mercadoria Virtual}

A Constituição Federal em seu artigo 155 outorga aos Estados a competência para tributação das "operações relativas à circulação de mercadorias e sobre prestações de serviços de transporte interestadual e intermunicipal e de comunicação, ainda que as operações e as prestações se iniciem no exterior”.

\footnotetext{
${ }^{587}$ Cf. BRAGHETTA, Daniela de Andrade, op. cit. (nota 87), p. 73.

588 Cf. AUSTIN, J. L., Sense and Sensibilia, Oxford, The Clarendon Press: 1963. Apud BRAGHETTA, Daniela de Andrade, op. cit. (nota 87), p. 73.

${ }^{589}$ Cf. GRECO, Marco A., op. cit. (nota 86), p. 52.
} 
O termo "mercadoria", que adjetiva as operações sobre as quais incide o imposto, definindo a base da tributação do ICMS, tem sido entendido como "a coisa móvel objeto da mercancia”, que classicamente alcança apenas bens corpóreos.

José Eduardo Soares de Melo ensina que, tradicionalmente, "mercadoria" "é bem corpóreo da atividade empresarial do produtor, industrial ou comerciante". 590

E sendo conceito utilizado pela Constituição Federal para definir competência tributária, que tem seu conteúdo e alcance definidos pelo direito privado, não pode ser alterado por lei tributária, nos termos do disposto no art. 110 do Código Tributário Nacional. ${ }^{591}$

Tal insuficiência do signo se evidencia no caso do software, que em si não é um bem corpóreo, cuja tributação pelo ICMS teve como base o corpus mechanicum representado pelo disquete, conforme restou assente no julgamento do RE $\mathrm{n}^{\mathrm{o}}$ 176.626-SP, Relator Sepúlveda Pertence. ${ }^{592}$

Para Marcos Aurélio Greco, os avanços da tecnologia e da informática fizeram surgir uma nova classe de bens incorpóreos relevantes economicamente, que não estariam abrangidos no clássico conceito de "mercadoria", "a menos que ele venha a ser reinterpretado para alcançar todos os bens negociados no mercado, o que não pode se coadunar com a Constituição". 593

No entanto, o conceito de "mercadoria", consagrado há mais de quarenta anos ${ }^{594}$, foi ampliado em seu sentido constitucional quando o legislador originário de 1988 submeteu a energia elétrica (coisa incorpórea) à tributação do ICMS, passando esta a ter natureza mercantil, conforme previsto no artigo 155, § $3^{\circ}$ da CF. ${ }^{595}$ A despeito disto, José Eduardo Soares de Melo é contundente em afirmar que o download, assim como o

${ }^{590}$ MELO, José Eduardo Soares. ICMS - Teoria e Prática, 9a ed., São Paulo, Dialética, 2006, p.16.

${ }^{591}$ CTN, Art. 110. "A lei tributária não pode alterar a definição, o conteúdo e o alcance de institutos, conceitos e formas de direito privado, utilizados, expressa ou implicitamente, pela Constituição Federal, pelas Constituições dos Estados, ou pelas Leis Orgânicas do Distrito Federal ou dos Municípios, para definir ou limitar competências tributárias."

${ }^{592} \mathrm{O}$ tema da tributação do software será abordado no item 6.1 do presente trabalho.

${ }^{593}$ GRECO, Marco A., op. cit. (nota 86), p. 53.

${ }^{594} \mathrm{O}$ art. 24, II da CF/67 e o art. 23 II da CF/69 já definiam "mercadoria" como materialidade do ICM Imposto sobre Circulação de Mercadorias, que na CF/88 passou a denominar-se ICMS, englobando ainda os serviços de telecomunicações e transporte.

595 Texto do $\S 3^{\circ}$ do art. 155 promulgado em 05 de outubro de 1988 - " $§ 3^{\circ}$ À exceção dos impostos de que tratam o inciso I, b, do caput deste artigo e os arts. 153, I e II, e 156, III, nenhum outro tributo incidirá sobre operações relativas a energia elétrica, combustíveis líquidos e gasosos, lubrificantes e minerais do País." Disponível em: <http://www.senado.gov.br/legislacao/const/con1988/CON1988 05.10.1988/art_155_.shtm>. Acesso em 2 de setembro de 2012 . 
fornecimento de produtos, bens e serviços de diversificada natureza, tais como passagens aéreas, banco eletrônico, leilões, publicidade, música, não caracterizam "mercadoria”. 596

Tratar-se-iam de "bens digitais" que constituem

conjuntos organizados de instruções, na forma de linguagem de sobrenível, armazenados em forma digital, podendo ser interpretados por computadores e por outros dispositivos assemelhados, que produzam funcionalidades predeterminadas. Possuem diferenças específicas tais como sua existência não-tangível de forma direta pelos sentidos humanos e seu trânsito por ambiente de rede teleinformática, uma vez que não se encontram aderidos a suporte físico. ${ }^{597}$

Estes "bens digitais" não estariam compreendidos no espectro de tributação do ICMS, não se constituindo em "mercadorias", conforme definido no ordenamento vigente. ${ }^{598}$

\subsubsection{Serviço $x$ Utilidade}

A noção de "serviço" enquanto atividade que representa um esforço humano exercido por alguém (obrigação de fazer) foi construída considerando-se a natureza do resultado desta atividade desenvolvida. Tanto assim, que a Lei Complementar exigida pelo art. 156, III da CF/88 (LC 116/03) identifica, em sua lista anexa, as atividades (serviços) sobre os quais incide o Imposto sobre Serviços e define que a base de cálculo do tributo corresponde justamente à contraprestação da atividade desenvolvida, isto é, ao preço do serviço.

Considerando as novas atividades que despontaram em função da tecnologia digital, que no sentir de Marco Aurélio Greco podem não ser alcançadas pela tributação baseada no conceito tradicional, foi proposta uma nova visão a ser considerada, que é aquela do cliente, para quem a relevância não está na natureza ou dimensão da atividade, mas na "utilidade" que será obtida. Desta forma, a noção de prestação de serviço passaria a ser vista como um fornecimento de utilidades, ainda que imateriais. ${ }^{599}$

No sentir de Aires F. Barreto, a incidência do ISS prescinde que a prestação do serviço cause algum benefício a terceiro, posto que "o ISS não é um imposto

\footnotetext{
${ }^{596}$ Cf. MELO, José Eduardo Soares, op. cit. (nota 590), p.18.

${ }^{597}$ EMERENCIANO, Adelmo da Silva, op. cit. (nota 39), p. 83.

${ }^{598}$ Cf. MELO, José Eduardo Soares, op. cit. (nota 590), p.19.

${ }^{599}$ Cf. GRECO, Marco Aurelio, op. cit. (nota 86), p. 55.
} 
sobre a utilidade (...) só pode recair sobre a prestação e não sobre o efeito que ela pode acarretar". 600

A visão da "utilidade" se coaduna com o pensamento de Chang Hee Lee que alertou para o fato de que as novas tecnologias permitem que o trabalho humano seja preservado e reutilizado ${ }^{601}$, adequando-se ao conceito clássico de "capital" e não mais "trabalho". Vale dizer, o esforço humano, a atividade se realizará apenas uma vez, no entanto, o resultado poderá ser utilizado e desfrutado ilimitadamente. ${ }^{602}$

Segundo as regras atuais de qualificação, há diferença entre a aquisição por uma empresa de 100 mil discos do Windows da Microsoft, ou a aquisição de um único disco que contenha a mesma quantidade de licenças incorporadas. Economicamente, a empresa está adquirindo exatamente a mesma utilidade, no entanto, no primeiro caso, o valor recebido na operação pela Microsoft será considerado como lucro e, no segundo caso, como royalties. ${ }^{603}$

Por outro giro, a visão do serviço enquanto "utilidade" poderia solucionar os mencionados problemas com a qualificação das rendas, permitindo que o conceito passe a abranger também as novas realidades virtuais. Além disto, tal teoria poderia evidenciar uma nova visão em relação ao local onde deve ser tributado o serviço: aquele em que o serviço produz seus efeitos (onde o resultado do serviço demonstra ter "utilidade" para o tomador). ${ }^{604}$

Desloca-se, desta forma, a tributação do local onde ocorreu a atividade do prestador, passando a considerar a visão do tomador do serviço, elegendo como local da prestação do serviço aquele onde foi obtida a "utilidade" adquirida, o resultado proporcionado pela atividade, ou pela reprodução de determinada mídia eletrônica.

A tese não é inédita em nosso ordenamento, já que a Lei Complementar $\mathrm{n}^{\circ} 116 / 2003$, no que concerne às importações e exportações de serviços, que assumem extrema relevância no contexto do comércio eletrônico, considera a "utilidade" produzida pelo serviço representada pelo "resultado", e não a "atividade" desenvolvida pelo prestador. ${ }^{605}$

${ }^{600}$ BARRETO, Aires F., op. cit. (nota 438), p. 126.

${ }^{601}$ Os trabalhos digitais podem ser preservados mediante a função save da linguagem informática, que possibilita sua reprodução permanente.

${ }^{602}$ Cf. LEE, Chang Hee, op. cit. (nota 215). Acesso em 06 de junho de 2012.

${ }^{603}$ Cf. Idem, ibidem. Acesso em 6 de junho de 2012.

${ }^{604}$ Cf. SILVA, Emerson Drigo, op. cit. (nota 102), p. 84.

${ }^{605}$ Cf. Idem, ibidem, p. 85. 
Vejamos os dispositivos:

Art. $1^{\circ}$. O Imposto Sobre Serviços de Qualquer Natureza, de competência dos Municípios e do Distrito Federal, tem como fato gerador a prestação de serviços constantes da lista anexa, ainda que esses não se constituam como atividade preponderante do prestador.

$\S 1^{\circ}$. O imposto incide também sobre o serviço proveniente do exterior do País ou cuja prestação se tenha iniciado no exterior do País.

$[\ldots]$

Art. $2^{\circ}$. O imposto não incide sobre: I - as exportações de serviços para o exterior do País;

[...]

Parágrafo único. Não se enquadram no disposto no inciso I os serviços desenvolvidos no Brasil, cujo resultado aqui se verifique, ainda que o pagamento seja feito por residente no exterior.

Note-se que o dispositivo relativo à não incidência do imposto sobre a exportação de serviços para o exterior exclui do benefício aqueles serviços cujo resultado aqui se verifique. No entanto, o "resultado" não se confunde com a fruição do serviço, posto que a exportação se configura pela venda de produtos ou serviços para um país estrangeiro.

\subsection{Obrigação de Dar x Obrigação de Fazer}

A doutrina civilista há muito se empenha em distinguir a obrigação de “dar" da obrigação de "fazer". Segundo Venosa, na obrigação de "fazer", "o devedor se vincula a determinado comportamento, consistente em praticar um ato, ou realizar uma tarefa, donde decorre uma vantagem para o credor. Pode esta constar de um trabalho físico ou intelectual, como também da prática de um ato jurídico". ${ }^{606}$

Considerando que quem promete a entrega de determinada prestação em rigor também se vincula a um "dar", esclarece o autor que "dentro da ideia de 'fazer', encontra-se a de 'dar'". Por outro giro, os conceitos se entrelaçam e, para diferenciá-los, pode-se considerar que na obrigação "de dar" a prestação é de coisa e na "de fazer" existe uma prestação de coisa.

Para alguns doutrinadores, no entanto, não há qualquer diferença entre as obrigações de dar e fazer; Monteiro de Barros adverte que parte da doutrina alienígena 
refuta esta distinção; para a doutrina francesa, as obrigações de dar (que são um tipo particular de obrigações de fazer) são espécies do gênero obrigações de fazer, estando por elas abrangidas. Para Monteiro,

o substractum da diferenciação está em verificar se o "dar" ou o "entregar" é ou não consequência do "fazer". Assim, se o devedor tem de dar ou de entregar alguma coisa, não tendo, porém, de fazê-la previamente, a obrigação é de dar; todavia, se, primeiramente, tem ele de confeccionar a coisa para depois entregá-la, se ele tem de realizar algum ato, do qual será mero corolário o de dar, tecnicamente a obrigação é de fazer. ${ }^{607}$

Mas adverte o autor que, algumas vezes, a distinção é tão sutil que se torna quase impossível fixar com exatidão a diferença. Monteiro ilustra a tese com o exemplo de uma empreitada, regida pelos artigos 610 e seguintes do Código Civil de 2002, que abarca o fornecimento de mão-de-obra e dos materiais necessários, em que estão presentes simultaneamente as obrigações de "dar" e de "fazer".

São as denominadas "operações mistas", cuja solução exige a utilização de critérios como a distinção entre atividade-meio e atividade-fim, serviços meramente acessórios ou preparatórios e o princípio da preponderância dos serviços prestados. É o caso típico dos restaurantes, em que se discute se há ali uma compra de "mercadoria" ou a contratação de uma série de serviços, como o do garçom, cozinheiro e outros. Neste sentido, já havia se manifestado Aliomar Baleeiro, sob o seguinte teor:

Note-se que, nessa modalidade, muitas vezes, o fornecimento está consorciado a uma prestação de serviços, utilização de mesas, copos, louças, talheres, guarnição de toalhas e guardanapos, trabalhos de garçons, o próprio local aprazível e panorâmico, música de fundo, pista de dança, etc. A operação deveria envolver matéria também de imposto municipal de serviço, que então recairia sobre a diferença entre o total cobrado e a parcela relativa aos valores das mercadorias. 608

Já em 1977, o então Ministro Rodrigues Alckmin, no voto do RE 85.262, utilizando a supramencionada lição de Baleeiro, arrematou:

[...] na realidade, ao fornecimento de alimentação em restaurantes e bares se sobrepunham fatos típicos de prestação de serviços e de fornecimento de alimentação para consumo local. Não se desenhava, portanto, uma exata hipótese de incidência de circulação de mercadorias,

${ }^{607}$ Cf. MONTEIRO, Washington de Barros, Curso de Direito Civil - Direito das Obrigações, $1^{a}$. Parte, Atualizada por Carlos Alberto Dabus Maluf, 32a . ed., São Paulo, Saraiva, 2003, p. 91.

${ }^{608}$ BALEEIRO, Aliomar, Direito Tributário Brasileiro, Apud RE 732.496/RS. 
consistente na saída desta do estabelecimento pela transferência de propriedade ou da posse nos termos da lei local. ${ }^{609}$

Muitos foram os julgados relativos às operações mistas, como o RE 171.808/SP, em cujo bojo o Ministro Marco Aurélio manifesta-se, como em recursos precedentes, pela inviabilidade da separação dos serviços, entendendo que aqui o melhor critério seja o do valor preponderante e de que a circulação de mercadoria tenha supremacia sobre o serviço contido nestas operações.

$\mathrm{Na}$ época, havia uma lei complementar que regulamentava o ICMS, a Lei 5.886/87, que definia que sobre as refeições servidas em bares, restaurantes, hotéis e assemelhados incidia o imposto estadual, e que a base de cálculo era o valor total da refeição, não fazendo qualquer menção aos serviços ali prestados.

Nos termos da manifestação do relator no Recurso Extraordinário supramencionado, o repasse de $25 \%$ do valor arrecadado a título de ICMS aos Municípios compensaria tais fatos pelo sistema legal de reciprocidade, até porque tal serviço não consta da lista. Da mesma forma, algumas prestações de serviço que envolvem o fornecimento de mercadorias têm como base de cálculo o valor total do serviço, sem qualquer desconto.

A conclusão do julgado é pelas inúmeras inconveniências na tentativa de decompor a base de cálculo nestes casos, entendendo que o sistema é prático e equilibrado, tendo sido definido de maneira justa, compensando-se umas hipóteses com outras. Além disto, caso fosse acatada a tese dos Municípios de que não incide ICMS por tratar-se essencialmente de serviço, os restaurantes seriam beneficiados, posto que, sem a previsão na lista de serviços, não seria possível a incidência do ISS.

O tema do fornecimento de refeições foi objeto da Súmula $n^{\circ} 163$ do Superior Tribunal de Justiça, editada em 12.06.1996, com o seguinte teor: "O fornecimento de mercadorias com simultânea prestação de serviços em bares, restaurantes e estabelecimentos similares constitui fato gerador do ICMS a incidir sobre o valor total da operação".

Desde a DL 406/68, o legislador tem se preocupado com as chamadas “operações mistas" e a distinção entre mercadoria e serviço, indispensável à dupla tributação, adotando a unicidade como critério de nítido caráter compensatório. Já naquela 
legislação, os serviços relacionados, mesmo que acompanhados de fornecimento de mercadorias, são tributados pelo ISS, enquanto o fornecimento de mercadorias, com prestação de serviços não relacionados, fica sujeito ao ICMS, considerado, para ambos os casos, o valor total da operação.

Os critérios para a delimitação dos campos de competência tributária entre Municípios e Estados já foram indicados pelo Supremo Tribunal Federal e decorrem do sistema normativo específico. O tema foi explanado no item 4.2 do presente trabalho, ao qual remetemos o leitor.

\subsection{Conceito de "Serviço" na Legislação Infraconstitucional}

No RE 346.084/PR, já mencionado, o Min. Cezar Peluso salientou que, quando não existir um conceito constitucional, deve o intérprete, antes de construir qualquer significado, perquirir nas disposições infraconstitucionais a existência de alguma prescrição de significado para o termo. Segundo ele, havendo correspondente semântico no ordenamento, deve-se presumir de "que a ele se refere o uso constitucional". E prossegue afirmando que, caso um signo utilizado pela Constituição Federal possua mais de um significado, e um deles já se encontra incorporado ao ordenamento jurídico, este é que deve prevalecer, pois não estaria o texto constitucional se referindo a objeto extrajurídico. ${ }^{610}$

E este foi o caminho trilhado pelo Min. Joaquim Barbosa em voto-vista no RE 547.245, quando, descartando a existência de um conceito constitucional de “serviços”, passou a perquirir sua existência no ordenamento jurídico nacional ${ }^{611}$

O Código Civil Brasileiro, Lei 10.406/2002, regulamenta em seus artigos 593 a 609 o Contrato de Prestação de Serviços, sem, no entanto trazer uma definição do que seriam "serviços". O Código Civil anterior, Lei 3.071/1916, utilizava a expressão "locação de serviços", não consignando qualquer elemento para sua conceituação.

A Lei 8.078, de 11 de setembro de 1990, Código de Defesa do Consumidor, em seu $\S 2^{\circ}$ do art. $3^{\circ}$ define "serviço" como "qualquer atividade fornecida no mercado de consumo, mediante remuneração, inclusive as de natureza bancária, financeira,

${ }^{610}$ Trecho do voto-vista do Min. Cezar Peluso no RE 346.084/PR, Relator Ilmar Galvão, 08.11.2005, p. 50.

${ }^{611}$ Trecho do voto do relator Min. Eros Grau no RE 547.245/SC. 
de crédito e securitária, salvo as decorrentes das relações de caráter trabalhista." Esta definição legal já foi considerada constitucional pelo STF no julgamento do ADI 2.591.

\subsection{O critério Espacial do Imposto Sobre Serviços de Qualquer Natureza}

O critério espacial da regra-matriz de incidência de um tributo possui especial relevo ao delimitar e constituir, além de seu âmbito de validade, a própria competência impositiva de cada um dos entes políticos, na medida em que define o local em que o fato jurídico deve ocorrer para que irradie seus efeitos.

Os municípios possuem competência para instituir o ISS no âmbito de seu território, dentro de seus limites geográficos. Esta é a exegese constitucional, considerando que o legislador adotou um critério territorial para a atividade impositiva dos tributos. Mesmo que o critério espacial não venha mencionado de modo expresso no texto constitucional, deve o intérprete perquirir as indicações, ainda que tácitas, para precisar o local da ocorrência dos fatos jurídicos. Segundo Roque A. Carrazza, "por injunção constitucional, a lei que cria, in abstracto, o ISS só pode irradiar efeitos sobre os serviços prestados no território do Município que a editou". ${ }^{612}$

No entanto, é tarefa das mais complexas a localização no espaço do local em que se realizou uma prestação do serviço. A uma, por tratar-se de bem incorpóreo, imaterial, e a duas, porque o processo pode desdobrar-se em etapas, tarefas, que não necessariamente se dão de maneira estática em um único local.

É neste sentido que surgem os conflitos de competência entre os Municípios, sobre os quais é relevante a lição de Aires F. Barreto:

Os conflitos intermunicipais são deflagrados em razão das peculiaridades do prestador ou da própria prestação de serviços. São conflitos entre a lei instituidora do ISS do Município "X" e a lei do ISS do Município "Z" (ou ainda, de diversos outros Municípios), em razão da pretensão de mais de um Fisco entender "seu" determinado fato imponível. Por tais motivos é extremamente importante, no caso do ISS, a definição legal das circunstâncias de lugar, consideradas juridicamente relevantes, para efeito de regular o surgimento das relações tributárias respectivas. ${ }^{613}$ (grifo nosso)

${ }^{612}$ Cf. CARRAZZA, Roque, op. cit. (nota 326), p. 967.

${ }^{613}$ BARRETO, Aires F, Curso de Direito Tributário Municipal, São Paulo, Saraiva, 2009, p. 345. 
Como se vê, no caso do ISS, torna-se imperiosa a definição legal das circunstâncias jurídicas relevantes para a definição do local da incidência do imposto, não apenas no sentido do âmbito de validade da lei em si, mas ainda da relação entre os requisitos configuradores do local e a ocorrência do fato tributário. ${ }^{614}$

E leciona o mestre que, "como os fatos tributários, sem exceção, só podem ocorrer no tempo e no espaço, sobrelevam as consequências do critério territorial e do âmbito de validade da lei respectiva". E prossegue aclarando que "o local da ocorrência da prestação de serviço deve permitir se saiba qual a lei aplicável e que se identifique, também, qual o ente político-constitucional que, validamente, pode exigir o tributo." ${ }^{615}$

Deste modo, a lei instituidora do tributo de determinado Município pode alcançar, além dos fatos jurídico-tributários ocorridos nos limites de seu próprio território, ainda outros envolvidos por força da existência de um elemento de conexão, definido legalmente como suficiente a configurar a incidência do imposto, como a situação do efetivo "estabelecimento prestador", a exemplo do descrito no Decreto-lei no 406/68 e na Lei Complementar $n^{\circ}$ 116/2003. Descola-se, neste sentido, o âmbito de validade territorial da lei do critério espacial do imposto, que constituem, na verdade "entidades ontologicamente distintas". 616

Paulo de Barros Carvalho, concluindo que o campo de validade da lei e o critério espacial das normas jurídicas não guardam relação direta, sustenta que são incipientes as pesquisas científicas relativas ao aspecto espacial das hipóteses de incidência, alertando para a necessidade do desenvolvimento de estudos voltados ao tema. 617

\subsection{A Definição do Aspecto Espacial - Critérios Legais}

As normas tributárias, como todas as normas, têm sua validade em termos espaciais limitada a determinado território. De forma similar ao que ocorre em um

${ }^{614}$ Cf. BARRETO, Aires, op. cit. (nota 438), p. 321.

${ }^{615}$ Idem, ibidem, p. 316.

${ }^{616}$ CARVALHO, Paulo de Barros, op. cit. (nota 338), p. 256

${ }^{617}$ Cf. Idem, ibidem, pp. 281/282. 
jogo ${ }^{618}$, as normas definem, assim como as ações de um jogo, que os fatos jurídicos ocorrerão em conformidade com regras preestabelecidas em determinado espaço físico.

Os denominados "enunciados prescritivos que estabelecem limites de espaço", tratados por Daniela Braguetta, determinam o "âmbito de validade da norma" e, na maioria das vezes, encontram-se implícitos no sistema jurídico. Tais enunciados, quando coincidem com os limites geográficos do ente político, estabelecem o âmbito de validade territorial de um tributo. No entanto, podem tais normas explicitamente definir áreas ou regiões específicas para a ocorrência de determinada ação, como é o caso do IPTU, cujas regras são aplicáveis exclusivamente à área urbana de determinado município. Por fim, o enunciado prescritivo pode definir, para a ocorrência do fato típico, de maneira expressa, um local determinado, como o "estabelecimento prestador" para o ISS. ${ }^{619}$

O Ato Complementar $\mathrm{n}^{\circ} 36$, de 13.3.1967, que atribuiu a denominação de Código Tributário Nacional à Lei $\mathrm{n}^{\circ} 5.172$, foi o primeiro ato normativo que tratou especificamente do aspecto espacial do ISS, definindo o "local da operação" nos casos em que os serviços são prestados em mais de um Município. Vejamos o teor do artigo:

Art. $6^{\circ}$ No caso de empresas que realizem prestação do serviço em mais de um Município, considera-se local da operação para efeito de ocorrência do fato gerador do imposto municipal correspondente:

I - O local onde se efetuar a prestação do serviço.

a) no caso de construção civil;

b) quando o serviço for prestado, em caráter permanente, por estabelecimentos, sócios ou empregados da empresa, sediados ou residentes no Município;

II - O local da sede da empresa, nos demais casos. ${ }^{620}$

Procurando preservar a efetividade da competência tributária dos Municípios e evitar conflitos, estabeleceu-se a regra de que os serviços se presumiam ocorridos na sede, considerando que os serviços deveriam ser tributados no local em que fossem "entregues ao cliente", motivo pelo qual o serviço de construção civil, que inevitavelmente será sempre "entregue" em local diverso da sede da empresa, constituiu exceção à regra estabelecida no caput. ${ }^{621}$

${ }^{618}$ A analogia entre as regras dos jogos e aquelas do direito foi estabelecida por Gregório Robles em sua obra Las reglas Del derecho y las reglas de los juegos. Apud BRAGHETTA, Daniela de Andrade, op. cit. (nota 87), p. 54.

${ }^{619}$ Cf. BRAGHETTA, Daniela de Andrade, op. cit. (nota 87), p. 54.

${ }^{620}$ Artigo $6^{\circ}$ do Ato Complementar $n^{\circ} 36$, de 13.03.1967.

${ }^{621}$ Cf. OLIVEIRA, José Marcos Domingues, Imposto sobre Serviços e Fato Gerador - o Local da Prestação de Serviços, Revista Dialética de Direito Tributário, São Paulo, Dialética, no. 105, p. 71. 
O Decreto-lei $n^{\circ} 406 / 68$ consignou em seu artigo 12 as regras relativas ao local da prestação dos serviços; a regra era o "estabelecimento" ou, na falta deste, o domicílio do prestador, e a única exceção prevista originariamente era a mesma contida no diploma legal anterior: os serviços de construção civil, que se consideravam prestados no local da obra de engenharia. A Lei Complementar $n^{\circ} 100$ veio acrescentar um novo dispositivo ao artigo, relativo ao serviço de pedágio, estabelecendo como competente o Município em cujo território haja parcela da estrada explorada.

Ou seja, adotou a lei complementar um elemento de conexão ${ }^{622}$ com o território do Município como suficiente para configurar a ocorrência dos fatos jurídicotributários de prestação de serviço, fazendo com que a lei instituidora do tributo do Município X tivesse eficácia em qualquer outro Município, desde que o estabelecimento prestador de serviços estivesse sediado naquele Município, o que afrontaria o princípio constitucional da territorialidade das leis tributárias. ${ }^{623}$

Para Aires Barreto e Roque Carrazza, a lei complementar, que tinha como função prevenir conflitos de competência entre os entes políticos, acabou por criar regra "de duvidoso apoio constitucional" que instaurou um caos na tributação do imposto. 624 A Lei Complementar $n^{\circ} 116 / 2003$ repisou aquela regra, trazendo, no entanto, a definição e os requisitos configuradores da expressão "estabelecimento prestador".

\subsection{1. Âmbito de Incidência $x$ Âmbito de Validade da Norma}

No sentir de Aires Barreto, há somente um único critério espacial possível definido pela Constituição Federal relativo ao ISS, que é o local onde se conclui a prestação do serviço, produziram-se seus efeitos e esta foi consumada, sendo inadmissível a imposição de quaisquer critérios que considerem, para a incidência do tributo, aspectos econômicos, contábeis ou fiscais. ${ }^{625}$

Na vigência do Decreto-lei $n^{\circ} 406 / 68$, o Superior Tribunal de Justiça, baseando-se em "suposto 'princípio constitucional implícito que atribui àquele Município

${ }^{622}$ Elemento de conexão é "um dos instrumentos nucleares em torno do qual se articula toda a estrutura da norma de conflitos. Integrado na hipótese da norma de conflito - desempenhando a função de "lançar ponte" entre o fato descrito pelo conceito-quadro e o ordenamento jurídico aplicável." XAVIER, Alberto, op. cit. (nota 08), p. 217.

${ }^{623}$ Cf. CARRAZZA, Roque, op. cit. (nota 326), p. 967.

${ }^{624}$ BARRETO, Aires, op. cit. (nota 438), p. 321, e Cf. CARRAZZA, Roque, op. cit. (nota 08), p. 969.

${ }^{625}$ Cf. BARRETO, Aires, op. cit. (nota 438), p. 322. 
poder para tributar o serviço ocorrido em seu território" " ${ }^{626}$, uniformizou seu entendimento sobre o tema, afastando o disposto no art. 12 daquele diploma. O mencionado dispositivo estabelecia o âmbito espacial da regra-matriz do Imposto sobre Serviços, considerando, em regra, como local da prestação do serviço aquele do "estabelecimento prestador" ou, na falta de estabelecimento, o do domicílio do prestador.

Desta forma, numa primeira abordagem, considerando-se que cada fato jurídico (de prestação de serviço) subsume-se a uma única norma instituidora do ISS, poder-se-ia afirmar que a lei ordinária que institui o imposto em cada um dos Municípios é válida dentro dos limites de seu território, incidindo apenas sobre os serviços ali realizados.

Para Misabel Derzi e Coelho, o art. 12 do Decreto-lei, que introduzia a regra do "local do estabelecimento prestador",

não fere a Constituição, nem agride o princípio de validade territorial das normas municipais. Os Municípios têm competência para tributar todos os serviços prestados em seu território, quer sejam nele executados, quer sejam executados em outros ou ainda fora do território nacional, no exterior. Basta para isso, que o estabelecimento prestador esteja nele situado. (g.n.) ${ }^{627}$

O problema, revelado na distinção entre o âmbito de incidência e o âmbito de eficácia das leis tributárias no espaço, é enfrentado pelo Direito Tributário Internacional, relativamente a situações internacionais havidas nas legislações tributárias. O âmbito de incidência (ou validade) está ligado à definição da abrangência de uma norma tributária interna sobre fatos, pessoas e coisas localizados no território de outro Estado, enquanto o âmbito de eficácia refere-se à problemática da existência, ou não, de coercitividade de uma lei tributária em território estrangeiro. ${ }^{628}$

Segundo Alberto Xavier, "o problema do âmbito de incidência das leis tributárias respeita ao âmbito do poder legislativo do Estado, à atividade tributária em abstrato [...]; o problema do âmbito de eficácia das leis tributárias refere-se ao âmbito do poder executivo do Estado, à atividade tributária em concreto". ${ }^{629}$ E conclui que ambos são indissociáveis, vez que de nada adiantaria um Estado alargar o âmbito de incidência das suas leis se não fosse possível assegurar-lhes eficácia coercitiva.

${ }^{626}$ COELHO, Sacha Calmon Navarro e DERZI, Misabel Abreu Machado, op. cit. (nota 508), p. 130.

${ }^{627}$ Idem, ibidem, p. 130.

${ }^{628}$ Cf. XAVIER, Alberto, op. cit. (nota 08), p. 5.

${ }^{629}$ Idem, ibidem, p. 7. 
Derzi e Coelho já haviam alertado para a distinção necessária entre "o âmbito de validade territorial das normas municipais (que coincide com o território das pessoas tributantes) e o aspecto espacial da hipótese - que pode coincidir ou não com o âmbito de validade territorial das normas". ${ }^{630}$

Paulo de Barros Carvalho há muito se referiu ao "frequente embaraço dos especialistas ao conceituar o critério espacial das hipóteses tributárias. Muita vez o encontramos identificado como o próprio plano de eficácia territorial da lei, como se não pudesse adquirir feição diferente". ${ }^{631}$

E reafirma que resta nítido que "critério espacial da hipótese e campo de eficácia da lei tributária são entidades ontologicamente distintas”. E traz uma referência prática para ilustrar a distinção.

O IPI, tomado na regra que prevê a incidência sobre a importação, e o IR, ambos de competência da lei federal, apresentam critérios espaciais radicalmente diversos: o fato jurídico tributário, na primeira hipótese, há de ocorrer nas repartições aduaneiras, de número limitado e situadas em localidades determinadas. Por outro lado, o IR alcança, em linhas genéricas, não só os acontecimentos verificados no território nacional, mas até fatos, explicitamente tipificados, e que se compõem para além de nossas fronteiras. A análise da regra-matriz de incidência do IPTU mostra o desencontro, com precisão geométrica. O tributo grava, privativamente, os imóveis localizados dentro do perímetro urbano do Município. Inobstante isso, a lei municipal efunde sua eficácia por toda a extensão do território correspondente, atingindo zonas rurais, excluídas do impacto tributário. ${ }^{632}$

Vale dizer, o critério espacial das normas tributárias não se confunde com o campo de validade das leis. Pode ocorrer que, por opção do legislador, elas coincidam, sendo esta, entre as várias opções técnicas que a ele se apresentam, a menos elaborada e mais elástica. ${ }^{633}$

Muitos são os fundamentos legais para "redução" ou "expansão" do âmbito de validade territorial, que estão normalmente centrados em causas e políticas diversificadas, como a similaridade de tratamento tributário nas relações internacionais, na proteção ao mercado interno, na isonomia garantida aos produtos, bens e serviços gerados

${ }^{630}$ COELHO, Sacha Calmon Navarro e DERZI, Misabel Abreu Machado, op. cit. (nota 508), p. 131.

${ }^{631}$ CARVALHO, op. cit. (nota 338), p. 291.

${ }^{632}$ Idem, ibidem, p. 291.

${ }^{633}$ Cf. Idem, ibidem, p. 292. 
no País, na necessidade de se evitar a bitributação, ou de se dirimir os conflitos entre os entes políticos internos por meio das normas gerais de Direito Tributário. ${ }^{634}$

Neste sentido, o Código Tributário Nacional, que é lei complementar em sentido material, reduziu o âmbito de incidência do Imposto sobre a Propriedade Territorial, elegendo o critério da zona urbana municipal, capaz de dirimir conflito de competência entre os Municípios e a União na definição da propriedade urbana e rural. Da mesma forma, a Lei Complementar $n^{\circ}$ 116/2003 (e anteriormente o Decreto-lei ${ }^{\circ}$ 406/68) desempenha idêntico papel, trazendo um critério para âmbito espacial do ISS, que não pode ser rejeitado, sob pena de infringir diretamente as normas constitucionais. ${ }^{635}$

Transpostos os conceitos de "âmbito de incidência" e "âmbito de eficácia das leis tributárias no espaço" para o ordenamento jurídico interno, e considerando as normas relativas ao ISS, a Constituição Federal teria determinado na outorga de competência o âmbito de incidência das normas municipais a seus territórios, ao passo que a legislação complementar, cumprindo a função precípua de evitar conflitos de incidência, mitigou o princípio da territorialidade, definindo como elemento de conexão o “estabelecimento prestador", determinando e criando um âmbito de eficácia para estas legislações.

Considerando-se que é o próprio texto constitucional que atribui à lei complementar a função de estabelecer normas gerais, é forçoso admitir que possuam função vinculante relativamente a todos os Municípios, cabendo-lhes acatar o âmbito de eficácia demarcado pelo critério definido naquela legislação, que pode diferir daquele âmbito de incidência (ou validade da lei municipal).

\subsubsection{A Lei Complementar $n^{\circ} 116 / 2003$}

Na vigência da Constituição de 1988, no tocante ao ISS, além daquelas atribuições gerais estabelecidas no art. 146, conferiu o constituinte originário à lei complementar no art. 156 a função de delimitar os serviços sobre os quais incidirá o Imposto sobre Serviços de Qualquer Natureza. Elegeu assim o constituinte originário a

${ }_{634}^{63}$ Cf. COELHO, Sacha Calmon Navarro e DERZI, Misabel Abreu Machado, op. cit. (nota 508), p. 132.

${ }^{635}$ Idem, ibidem, p. 132. 
legislação complementar para narrar minuciosamente a delimitação da outorga de competência por ele iniciada. ${ }^{636}$

Neste sentido, veio a Lei Complementar $n^{\circ} 116$ de 2003, que veicula a Lista de Serviços sobre os quais incidirá o gravame municipal. Além disto, introduziu novas regras relativas ao critério espacial do ISS, cumprindo a função de "dispor sobre conflitos de competência, em matéria tributária, entre a União, os Estados, o Distrito Federal e os Municípios”, nos termos do artigo 146, I, da Constituição Federal. ${ }^{637}$

Ou seja, a lista de serviços introduzida pela Lei Complementar relativa ao ISS possui função dúplice, já que, além de ser o veículo introdutor de normas jurídicas tributárias definidoras de quais os serviços ensejarão a incidência do tributo, cumpre, concomitantemente, a tarefa de evitar eventuais conflitos de competência verticais e horizontais. Neste mister, relativamente aos conflitos verticais, ao determinar as materialidades sobre as quais incide o tributo municipal, delimita o campo de tributação também dos outros entes, já que acaba por excluir a incidência do ICMS e do IPI sobre algumas materialidades.

No tocante aos conflitos horizontais, isto é, aqueles havidos entre entes do mesmo nível (Estado x Estado ou Município x Município), a LC 116/03 fixa o critério espacial aplicável à tributação do ISS; isto é, procede à fixação do local em que incidirá o imposto, desta forma elegendo o ente político competente para exigir o tributo e prevenindo conflitos entre municípios. Neste sentido, dispõe seu artigo $3^{\circ}$ a regra geral estabelecimento prestador ${ }^{638}$, relacionando ainda vinte espécies de serviços que constituem exceções àquela regra, quando o imposto será devido, de modo geral, no local da prestação do serviço.

Segundo Barreto, tanto o Decreto-lei $\mathrm{n}^{\circ}$ 406/68, quanto a Lei Complementar $n^{\circ} 116 / 03$, criaram regras que culminaram por instaurar um caos relativamente à definição do critério espacial, alegando que a regra relativa ao “estabelecimento prestador" surgiu em função da pressão política dos Municípios mais fortes economicamente. Reafirma o autor que, de acordo com o texto constitucional, o único critério espacial possível do ISS seria o local onde se efetivou, se concluiu a

${ }^{636}$ Cf. CARVALHO, Paulo de Barros, op. cit. (nota 19), p. 681.

${ }^{637}$ Disciplinava o assunto até então o artigo 12 do Decreto Lei 406/68.

${ }^{638} \mathrm{LC} 116 / 03$ - Art. $3^{\circ}$. O serviço considera-se prestado e o imposto devido no local do estabelecimento prestador ou, na falta do estabelecimento, no local do domicílio do prestador, exceto nas hipóteses previstas nos incisos I a XXII, quando o imposto será devido no local: [...]. 
prestação do serviço, e em que se produziram seus efeitos e se consumou o fato jurídicotributário, ${ }^{639}$ de forma que não deveriam existir conflitos de competência relativos ao tributo.

Roque A. Carrazza afirma que "os conflitos de competência em matéria tributária logicamente não existem e nem podem existir. [...] Com efeito, se o fato "A" só pode ser tributado pela pessoa política " $X$ ", não há de haver conflitos entre ela e as pessoas políticas "W", "Y”, “Z” etc". ${ }^{440}$ Mas admite que, na prática, eles existem, e que são provocados por uma lei tributária inconstitucional ou por uma pretensão administrativa ilegal (ou inconstitucional) da pessoa tributante. E prossegue afirmando que caberá somente o Judiciário "dizer o direito" nestes casos. ${ }^{641}$

José Eduardo Soares de Melo vislumbra no art. $3^{\circ}$ da LC no $116 / 2003$ quatro regras para fixação de competência do município para auferir o ISS, a saber:

(i) o Município do estabelecimento prestador (art. $3^{\circ}$, caput); (ii) o Município do local onde se situar o domicílio do prestador, no caso de inexistência do estabelecimento prestador (art. $3^{\circ}$, caput); (iii) o Município do local da prestação (serviços indicados nos incisos II a XXII, do art. $3^{\circ}$, I); e (iv) o Município do estabelecimento do tomador ou do intermediário do serviço; ou na falta de estabelecimento, onde ele estiver domiciliado, no caso de serviço proveniente do exterior do País, ou cuja prestação se tenha iniciado no exterior do País (art. $\left.3^{\circ}, \mathrm{I}\right){ }^{642}$

Portanto, a exegese dos dispositivos relativos ao critério espacial do Imposto sobre Serviços - ISS contidos na Lei Complementar $n^{\circ} 116 / 03$ nos permite fixar três critérios distintos:

a) a regra geral para a incidência do imposto considera o serviço prestado, e o imposto devido no município em que se situa o "estabelecimento prestador" ou, na falta deste, no local do domicílio do prestador;

b) no caso dos serviços cuja prestação, por suas peculiaridades fáticas, desenvolve-se notoriamente fora do estabelecimento prestador, enumerados nos incisos I a XXII do artigo $3^{\circ}$, o imposto será devido no local onde o serviço for executado;

${ }^{639}$ Cf. BARRETO, Aires, op. cit. (nota 438), p. 321.

${ }^{640}$ CARRAZZA, Roque Antonio, op. cit. (nota 326), p. 933.

${ }^{641}$ Idem, ibidem, p. 933.

${ }^{642}$ MELO, José Eduardo Soares, Curso de Direito Tributário, $7^{a}$ ed., São Paulo, Dialética, 2007, p. 479. 
c) na importação de serviços, ou nos serviços cuja prestação tenha se iniciado no exterior, o imposto será devido no estabelecimento do tomador ou intermediário do serviço; na falta de estabelecimento, onde ele estiver domiciliado.

Ainda sob a vigência do Decreto-Lei ${ }^{\circ}$ 406/68, Sacha Calmon Navarro Coelho e Misabel Derzi analisaram as regras relativas ao critério espacial do ISS, sintetizando-as da seguinte forma:

1. o Decreto-lei $406 / 68$, como norma geral que se presta a dirimir conflitos de competência, obriga a todas as pessoas estatais, sobrepondose às ordens jurídicas parciais da União, dos Estados e dos Municípios;

2. o legislador de normas gerais pode eleger critério espacial diferente do local da execução do serviço, desde que se mantenha conexão territorial, por exemplo, o local do estabelecimento prestador. Não há desnaturamento da regra-matriz do ISS, posta na Constituição; nem tampouco ofensa aos limites de territorialidade, pressupostos na Carta;

3. o conceito de local do estabelecimento prestador do serviço, eleito pelo Decreto-lei 406/68 como critério espacial do fato gerador, é conceito vinculado ao território municipal sob o ângulo do contribuinte-prestador, diferente evidentemente do local da execução do serviço, e seu afastamento pelo Poder Judiciário pode ensejar novos conflitos de competência entre diversos Municípios. Inexiste na Constituição critério que obrigue à eleição sistemática do local da execução do serviço (ângulo do usuário do serviço). (grifos dos autores) ${ }^{643}$

\subsubsection{O Estabelecimento Prestador}

A Lei Complementar $n^{\circ} 116 / 2003$, além de definir os critérios aplicáveis para a delimitação do Município competente para exigir o ISS sobre determinado fato jurídico, conceituou em seu artigo $4^{\circ}$ a expressão "estabelecimento prestador”:

Art. $4^{\circ}$. Considera-se estabelecimento prestador o local onde o contribuinte desenvolva a atividade de prestar serviços, de modo permanente ou temporário, e que configure unidade econômica ou profissional, sendo irrelevantes para caracterizá-lo as denominações de sede, filial, agência, posto de atendimento, sucursal, escritório de representação ou contato ou quaisquer outras que venham a ser utilizadas.

Referido conceito exige para a configuração do estabelecimento prestador dois requisitos conjuntos: (i) o local em que o contribuinte presta o serviço e (ii) que o local se configure em "unidade econômica". 
Estabelecimento, portanto, não é a empresa enquanto atividade ou algo estático, um local físico, mas a unidade econômica, abrangendo não apenas o espaço físico, mas o complexo de meios materiais e imateriais que possibilitam a exploração de determinada atividade.

O Novo Código Civil Brasileiro consignou em seu artigo 1.142 uma definição de estabelecimento, que compreende três elementos, a saber: (i) bens (corpóreos ou incorpóreos); (ii) a organização, como elemento funcional; e (iii) a finalidade de exercer a atividade empresarial. ${ }^{644}$

Misabel Derzi e Coelho assim definiram "estabelecimento prestador de serviços":

o complexo de coisas, como unidade econômica de empresa, que configure um núcleo habitual do exercício da atividade, supondo administração e gerência mínimas, aptas à execução do serviço. Tanto pode ser a sede, matriz, filial, sucursal ou agência, sendo irrelevante a denominação do estabelecimento e a centralização ou não da escrita da pessoa. O local onde se situa cada unidade econômica - assim entendido aquele do estabelecimento prestador do serviço - atrairá a incidência da norma municipal respectiva. ${ }^{645}$

Vale dizer, estabelecimento prestador pode ser considerado "qualquer local em que, concretamente, se exercite a função de prestar serviço". ${ }^{646}$

No que tange à identificação do "estabelecimento prestador" para efeito de incidência do ISS, a legislação de vários municípios estabelece o critério elencando uma série de elementos configuradores. ${ }^{647}$

Tomando como exemplo a legislação do Município de São Paulo, encontramos tal previsão inserta no artigo 50 da Lei $n^{\circ} 6.989 / 66$, com a redação dada pela Lei $n^{\circ} 9.664 / 83$, e no artigo $4^{\circ}$ da Lei 13.701/05, que elenca, além da definição de "estabelecimento prestador" em si, uma série de requisitos para sua configuração. Salientese que é inexigível para a configuração do "estabelecimento prestador" a presença de todos os elementos mencionados, admitindo-se a conjugação parcial destes. Vejamos:

Art. $4^{\circ}$ - Considera-se estabelecimento prestador o local onde o contribuinte desenvolva a atividade de prestar serviços, de modo

${ }^{644}$ Lei no 10.406/2002, Art. 1142: “Considera-se estabelecimento todo complexo de bens organizado, para exercício da empresa, por empresário, ou por sociedade empresária”.

${ }^{645}$ COELHO, Sacha Calmon Navarro e DERZI, Misabel Abreu Machado, op. cit. (nota 508), pp. 128 e 137.

${ }^{646}$ BARRETO, Aires F., op. cit. (nota 613), p. 348.

${ }^{647}$ Cf. Idem, op. cit. (nota 438), p. 328. 
permanente ou temporário, e que configure unidade econômica ou profissional, sendo irrelevantes para caracterizá-lo as denominações de sede, filial, agência, posto de atendimento, sucursal, escritório de representação ou contato ou quaisquer outras que venham a ser utilizadas. $\S 1^{\circ}$ - A existência de estabelecimento prestador que configure unidade econômica ou profissional é indicada pela conjugação, parcial ou total, dos seguintes elementos:

I - manutenção de pessoal, material, máquinas, instrumentos e equipamentos próprios ou de terceiros necessários à execução dos serviços;

II - estrutura organizacional ou administrativa;

III - inscrição nos órgãos previdenciários;

IV - indicação como domicílio fiscal para efeito de outros tributos;

V - permanência ou ânimo de permanecer no local, para a exploração econômica de atividade de prestação de serviços, exteriorizada, inclusive, através da indicação do endereço em impressos, formulários, correspondências, "site" na internet, propaganda ou publicidade, contratos, contas de telefone, contas de fornecimento de energia elétrica, água ou gás, em nome do prestador, seu representante ou preposto.

$\S 2^{\circ}$ - A circunstância de o serviço, por sua natureza, ser executado habitual ou eventualmente fora do estabelecimento não o descaracteriza como estabelecimento prestador para os efeitos deste artigo.

$\S 3^{\circ}$ - São, também, considerados estabelecimentos prestadores, os locais onde forem exercidas as atividades de prestação de serviços de diversões públicas de natureza itinerante.

A definição da Lei Complementar, assim como a da lei municipal aqui referida, contempla basicamente um elemento objetivo e um elemento subjetivo. $\mathrm{O}$ elemento objetivo, representado pela "unidade econômica ou profissional", além do estabelecimento físico, considera o complexo de bens da empresa necessários e inerentes ao exercício da atividade empresarial ou profissional. Engloba, assim, a estrutura física e organizacional que representa o local para a prestação em si, o pessoal técnico, a existência de maquinário ou equipamentos necessários ao serviço especificamente prestado, entre outros.

O elemento subjetivo da definição é o animus de permanência em determinado local para a prestação de serviços, evidenciado por circunstâncias externas que revelam esta intenção do sujeito. Ou seja, esta intenção se manifesta por meio de elementos como a inscrição do endereço em órgãos previdenciários, sua indicação como domicílio fiscal para outros tributos, a menção do estabelecimento em cartões, sites da Internet, publicidade, contas de energia elétrica, telefones fixos e outros que denotam a fixação naquele determinado lugar. ${ }^{648}$ 
A ocorrência efetiva de determinado fato neste ou naquele Município pode ser aferida pela demonstração de vários elementos, que servirão de indícios necessários e suficientes para evidenciar a existência do elemento subjetivo. É razoável presumir a fixação de um sujeito em determinado local pela comprovação da utilização de energia elétrica de modo regular, assim como água ou telefone fixo. Este é o motivo pelo qual a comprovação de residência das pessoas naturais é feita mediante a apresentação de contas de energia elétrica, gás, telefone fixo, água, que permitem presumir, pelo consumo efetivamente demonstrado, a residência destas, assim como o estabelecimento da pessoa jurídica.

Ou seja, para que comprove a existência do "estabelecimento prestador" é necessária a conjugação dos elementos objetivo e subjetivo, sendo insuficiente para tanto apenas a existência formal ou a presença de uma estrutura física.

A solução legislativa do estabelecimento prestador, já adotada pelo Decreto-lei $n^{\circ} 406 / 68$, que por muitos anos foi útil à solução de conflitos, foi aceita por Aliomar Baleeiro que entendeu que a norma "simplificou o problema", fazendo incidir o imposto no Município da sede do estabelecimento, se este presta serviço. E complementou argumentando que "pode acontecer até que o contribuinte preste o serviço em território estrangeiro, vizinho, como o médico de Santa Ana do Livramento que atenda a chamada de clientes residentes em Rivera (Uruguai)". ${ }^{649}$

\subsection{Elementos de Conexão, a Constituição Federal e a $\mathbf{L C} \mathbf{n}^{\circ}$ $116 / 2003$}

O elemento de conexão é um elemento normativo utilizado para demarcar o âmbito de aplicação das leis, determinando a "localização" de uma situação da vida em um ordenamento jurídico. Tem como função estabelecer ligações entre uma lei tributária e pessoas, bens ou fatos, classificando-se em objetivo e subjetivo. Este refere-se a pessoas, como "nacionalidade" ou a "residência", enquanto aquele reporta-se a coisas ou

${ }^{649}$ BALEEIRO, Aliomar, Apud COELHO, Sacha Calmon Navarro e DERZI, Misabel Abreu Machado, op. cit. (nota 508), p. 139. 
fatos, como "fonte de produção de renda", "lugar da situação dos bens", "lugar de celebração do contrato" ou "estabelecimento permanente". ${ }^{650}$

Segundo Xavier, constitui "um dos instrumentos nucleares em torno do qual se articula toda a estrutura da norma de conflitos" ${ }^{651}$, estabelecendo um vínculo entre determinada pessoa, bem ou fato e o ordenamento aplicável.

Estes elementos podem ainda ser constituídos por presunções ou ficções; Xavier, aludindo a ordenamentos alienígenas, traz como exemplo aquela norma que considera prestado determinado serviço no domicílio do prestador ou no domicílio do beneficiário e a relativa à definição do domicílio de um membro agregado, em que se considera o local em que reside o chefe da família. E conclui que, nestes exemplos, o conceito de lugar da prestação do serviço e a residência do titular dos rendimentos não são os elementos de conexão, mas sim os conceitos que serviram como base à presunção: o domicílio do prestador de serviço ou de seu adquirente e a residência do chefe de família. ${ }^{652}$

É na hipótese da norma que atua o elemento de conexão, substituindo algum dos critérios ali consagrados (material, espacial ou territorial); no caso do ISS, o elemento de conexão foi introduzido no critério espacial, "lançando a ponte" ${ }^{653}$ entre o fato ali descrito e o consequente imputado pelo modal deôntico.

A regra que estabelece o elemento de conexão atua como regra de estrutura, cujo mandamento atinge as outras normas, à semelhança do fenômeno que ocorre, normativamente, com as isenções tributárias. Na lição de Paulo de Barros Carvalho buscamos que as regras de estrutura

são os elementos ou as unidades do sistema normativo [...] que prescrevem o relacionamento que as normas de conduta devem manter entre si, dispondo também sobre sua produção e acerca das modificações que se queiram introduzir nos preceitos existentes, incluindo-se a própria expulsão de regras do sistema. ${ }^{654}$

Desta forma, as normas prescritoras que contêm os elementos de conexão introduzem alterações na própria regra-matriz de incidência do tributo, de modo a alterar

${ }^{650}$ Cf. XAVIER, Alberto, op. cit. (nota 08), p. 24.

${ }^{651}$ Idem, ibidem, p. 216.

${ }^{652}$ Idem, ibidem, p. 220.

${ }^{653}$ Segundo Alberto Xavier, a expressão "lançar a ponte" é a terminologia utilizada por RAAPE. Cf. XAVIER, Alberto, op. cit. (nota 08), p. 217.

${ }^{654}$ CARVALHO, op. cit. (nota 338), pp. 521-522. 
os efeitos que lhe são próprios. No caso específico dos elementos de conexão, eles atuam em um dos critérios da regra de incidência, alterando-o e substituindo, para determinados casos, o que foi definido na norma de competência.

Trata-se de fenômeno exclusivamente normativo, em que a regra de estrutura, prescrita pelo texto constitucional, tem um de seus aspectos alterado ou mesmo substituído, para consignar um novo critério. No caso específico do ISS, o critério espacial da regra-matriz é substituído pelo critério introduzido pela norma de estrutura veiculada pela lei complementar, passando a se considerar que o imposto incidirá no local em que estiver situado o "estabelecimento prestador".

Note-se que é irrelevante o que ocorre no plano fático, isto é, mesmo nos casos em que o "estabelecimento prestador" estiver faticamente localizado dentro do território do ente que expedir a norma, o fenômeno normativo é que o critério definido na legislação complementar coincide com o âmbito de validade da norma.

Isto porque, dentro do ordenamento jurídico brasileiro, pela natureza ontológica da lei complementar consignada pela própria Constituição, de prevenir conflitos de competência entre os entes políticos, o critério utilizado pelo legislador constitucional é atingido pela regra introduzida pela lei complementar, passando a regra-matriz de incidência do imposto a figurar um novo aspecto espacial, qual seja, o local em que se localiza o "estabelecimento prestador de serviços".

Neste sentido, afirma Alberto Xavier que, no Brasil, a legislação do ISS adotou como elementos de conexão o local do "estabelecimento prestador" ou, na falta de estabelecimento, o local do "domicílio do prestador". Desta forma, segundo aquele autor, mesmo no caso de os serviços serem executados no exterior, o ISS incidirá no território do município do estabelecimento ou do domicílio do prestador. Na circulação internacional de serviços, a opção foi pelo princípio da origem, em que se tributam as "exportações" de serviço realizadas por prestadores com estabelecimento no Brasil, exonerando-se as "importações" cujos beneficiários estejam aqui sediados. Saliente-se que, naqueles serviços abrangidos pelo ICMS, o princípio vigente é o do destino, cobrando-se o imposto na importação dos serviços e exonerando-se sua exportação. ${ }^{655}$

Analisando a utilização de elemento de conexão na definição do critério espacial do ISS, ainda sob a égide do Decreto-lei $n^{\circ} 406 / 68$, Sacha Navarro e Misabel 
Derzi sustentaram que a referida norma, lei complementar no sentido material, poderia ter elegido o "estabelecimento prestador" como tal.

Desta forma, o critério espacial da regra-matriz está totalmente adequado à hipótese de incidência do ISS, que considera a pessoa física ou jurídica prestadora de serviço, que denota a capacidade econômica, e não aquela que adquire o serviço. ${ }^{656}$

Prosseguem alegando ainda que, nas questões que envolvem ordens jurídicas diferentes, internas ou internacionais, os elementos de conexão com o território são tradicionalmente aceitos. E concluem que

o imposto incide sobre a prestação de serviços (não importa o local de sua execução, pois até mesmo aqueles prestados fora do território nacional, no exterior, estão situados no âmbito de incidência da norma) desde que o estabelecimento prestador ou a pessoa jurídica se situem em Município brasileiro. Pensar de forma diferente seria considerar supérflua a norma constitucional que autoriza a lei complementar federal a excluir da incidência do ISS "exportação de serviços para o exterior". [...] No último caso, da importação de serviços, a prevalecer o entendimento do Superior Tribunal de Justiça, jamais poder-se-ia cobrar ISS, uma vez que o local da execução do serviço seria critério constitucional inarredável." ${ }^{657}$

Por outro giro, se considerarmos que a Constituição Federal de 1988 somente permite a tributação dos serviços no local de sua efetiva prestação, seja pela existência de um princípio constitucional implícito ${ }^{658}$, seja pela interpretação sistemática de seu texto ${ }^{659}$, devemos concluir que a previsão contida no inciso II do $\S 3^{\circ}$, art. 156 da CF/88 da necessidade de Lei Complementar para excluir da incidência do imposto municipal as exportações de serviços é descabida. Ora, se tais exportações caracterizam-se pela realização de pelo menos parte dos serviços em território estrangeiro, não existiria a possibilidade de tributá-los, já que nenhum Município brasileiro deteria competência para alcançar a prestação destes serviços. Desta forma, a teoria de que o único critério espacial possível para o ISS segundo a CF/88 é o local da efetiva prestação dos serviços leva à conclusão de que há no bojo de nossa Carta Magna palavras inúteis ou controversas. ${ }^{660}$

Também no âmbito internacional, as relações relativas às prestações de serviço originam problemas de conexão territorial, o que levou a Comissão da Comunidade

${ }^{656}$ Cf. COELHO, Sacha Calmon Navarro e DERZI, Misabel Abreu Machado, op. cit. (nota 508), pp. 128/ 129.

${ }^{657}$ Idem, ibidem, pp. 128/129.

${ }^{658}$ Cf. SILVA, Emerson Drigo, op.cit. (nota 102), p. 44.

${ }^{659}$ Cf. BARRETO, Aires, op. cit. (nota 438), p. 322.

${ }^{660}$ Cf. SILVA, Emerson Drigo, op.cit. (nota 102), p. 44. 
Europeia a expedir uma diretiva tratando do tema, que prevê um complexo sistema de conexões, baseado nos seguintes elementos: (i) lugar do domicílio ou sede do prestador de serviços; (ii) o lugar da execução ou utilização do serviço; e (iii) o lugar do domicílio do beneficiário. Ao contrário da regra brasileira, não incide o IVA no caso de estar o prestador estabelecido em um de seus Estados-membros se o tomador estiver domiciliado fora da Comunidade Europeia. Da mesma forma, não incide o imposto em um Estado-membro se o prestador não estiver nele estabelecido e o beneficiário, ainda que estabelecido nele. ${ }^{661}$

\subsection{Os Conceitos Operacionais de "Desenvolvimento do Serviço" e "Verificação de seu Resultado"}

A questão relativa à incidência do ISS sobre serviços destinados ao exterior foi abordada em brilhante parecer de Humberto Ávila ${ }^{662}$, em que o mestre, esmiuçando os princípios federativo e da autonomia municipal, estabeleceu que a questão extrapola a mera avaliação da ocorrência ou não de um serviço no território municipal, impondo-se, outrossim, o exame dos conceitos de "desenvolvimento do serviço" e "verificação de seu resultado" neste território.

No caso sob análise, os serviços prestados eram de data center, que abrangia serviços de hospedagem de banco de dados e suporte técnico, assessoria e consultoria e serviços de coordenação para o desenvolvimento de produtos, assessoria e consultoria para a implementação de nova tecnologia/inovação nos novos ou atuais produtos. Estes serviços seriam prestados em estabelecimento localizado em Município brasileiro para as demais empresas do grupo localizadas em várias localidades do mundo, no exterior. ${ }^{663}$ Note-se que se tratam, justamente, de serviços prestados e disponibilizados por intermédio das modernas tecnologias da informação e da comunicação, de que tratamos no presente trabalho.

Considerando-se a regra imposta pelo art. $2^{\circ}$ da Lei Complementar $\mathrm{n}^{\circ}$ 116/03, que determina a isenção do imposto aos casos de exportação de serviços e que traz

\footnotetext{
${ }^{661}$ Cf. XAVIER, Alberto, op.cit. (nota 08), p. 236.

${ }^{662}$ Cf. ÁVILA, Humberto, Imposto sobre a Prestação de Serviços de Qualquer Natureza. Exportação de Serviços. Lei Complementar $n^{o}$ 116/2003. Isenção: Requisitos e Alcance. Conceitos de "Desenvolvimento" de Serviço e "Verificação" de seu Resultado”, Revista Dialética de Direito Tributário, São Paulo, Dialética, no 134, pp. 101/109.

${ }^{663}$ Cf. Idem, Ibidem, p. 101.
} 
reflexos diretos na autonomia dos Municípios, resta manifesto que não podem estes entes políticos exigir o imposto pelo simples fato de ter sido o serviço prestado, de algum modo, em território brasileiro.

Sob o argumento referido, entreviu Humberto Ávila no art. $2^{\circ}$ da Lei Complementar $n^{\circ}$ 116/2003 “conceitos operacionais" para a análise do critério espacial do tributo, evidenciados pela prevalência do resultado do serviço em face de seu desenvolvimento. Ou seja, segundo aquele autor, o legislador complementar optou por cindir o serviço em duas unidades de medida: o desenvolvimento e o resultado. ${ }^{664}$

Tendo como premissa que a Constituição Federal de 1988 incorporou um conceito infraconstitucional preexistente para "serviços", consubstanciado num "esforço humano empreendido em benefício de outrem para criar um bem material ou imaterial", estabeleceu que o núcleo semântico da palavra "resultado" é constituído, justamente, por este bem material ou imaterial. ${ }^{665}$

A relevância destes conceitos reside no próprio teor do artigo da Lei Complementar $n^{\circ} 116 / 2003$, que exclui da já mencionada regra de isenção os serviços desenvolvidos no Brasil, cujo resultado aqui se verifique. Em outras palavras, caso o resultado do serviço ocorra em território brasileiro incidirá o imposto, não se aplicando a regra de isenção.

Desta forma, para a validação do referido benefício é imperiosa a verificação de onde ocorre o resultado daquele esforço humano, tornando-se irrelevante o local em que este se desenvolveu. Neste contexto, o esforço humano constitui o desenvolvimento do serviço em si, enquanto o bem material ou imaterial representa o resultado visado pelas partes contratantes e remunerado pelo tomador do serviço.

$\mathrm{Na}$ opinião de Humberto Ávila, as categorias com as quais os operadores do direito estão habituados a trabalhar relativamente ao ISS tornaram-se insuficientes com a inovação trazida pelo legislador complementar; o foco da problemática da incidência no direito interno se concentrou sempre no processo de criação da utilidade que será utilizada por terceiro, isto é, no fazer, constituindo uma regra de competência "meramente casual: se foi praticado o esforço humano, há competência para a cobrança do imposto, onde isso ocorreu". 666

${ }^{664}$ Cf. ÁVILA, Humberto, op. cit. (nota 662), p. 107.

${ }^{665}$ Idem, ibidem, p. 105.

${ }^{666}$ Cf. Idem, ibidem, p. 107. 
A inclusão destes conceitos no ordenamento jurídico, segundo Ávila, não auxiliaria na definição do critério espacial do imposto sobre serviços, mas, antes, redimensiona a competência material dos municípios, excluindo de seu campo de incidência aqueles serviços cuja fruição do resultado se verifique no exterior. ${ }^{667}$ No entanto, entendemos que os conceitos apontados poderiam constituir ferramentas para os operadores do direito, na definição do local da prestação de serviços naquelas situações em que estes se desenvolvem com o auxílio das novas tecnologias da informação e da comunicação, servindo como critério doutrinário, e não legal, para a definição do critério espacial da regra-matriz do tributo.

\subsection{O Estabelecimento Virtual - Web Site}

Delimitar o conceito de estabelecimento para aquelas atividades econômicas, profissionais ou empresariais ocorridas no âmbito da Internet, de forma virtual ou eletrônica, apresenta-se como uma tarefa complexa.

Impulsionados pelos avanços das tecnologias da informação e da comunicação, as empresas expandiram ou mesmo transferiram suas atividades, antes desenvolvidas em estabelecimentos físicos, para estabelecimentos virtuais, denominados sites ou sítios.

A palavra site na língua inglesa possui o mesmo significado de "sítio" em português; ambas derivam do latim situs ("lugar demarcado, local, posição"). No Brasil, utiliza-se indistintamente a expressão "sítio" ou site, que foi adotada por nosso idioma para significar o "local na Internet identificado por um nome de domínio, constituído por uma ou mais páginas de hipertexto, que podem conter textos, gráficos e informações em multimídia". 668

Um site na Internet pode ter diversos propósitos, entre eles, o institucional, que visa a estabelecer contato entre as instituições e seus clientes e fornecedores, divulgando seus bens ou serviços, que podem também ser comercializados por meios eletrônicos.

Considerando-se o tipo de operações passíveis de serem realizadas em um site, Greco propôs a seguinte classificação: (i) site meramente passivo, em que ocorre

${ }^{667}$ Cf. ÁVILA, Humberto, op. cit. (nota 662), p. 107.

${ }^{668}$ Verbete site, Dicionário Houaiss, op. cit. (nota 54). Acesso em 23 de abril de 2011. 
apenas a divulgação de imagens ou mensagens; (ii) site canalizador de mensagens que, além de apresentar mensagens, recebe pedidos de compra de produtos ou de fruição de serviços; e (iii) site inteligente, quando, além de receber pedidos, realiza operações mais complexas, interagindo com o usuário, confirmando disponibilidade de produtos, emitindo ordens de compra ou serviço, informando prazo de entrega, recebendo pagamento mediante cartão de crédito, pagamento digital ou emitindo boletos bancários. No caso de bens incorpóreos, como softwares ou programas, o site inteligente disponibiliza ainda ao usuário o download ou acesso ao programa. ${ }^{669}$

Nos sites meramente passivos, as atividades viabilizam a divulgação e a oferta dos serviços, fazendo as vezes de uma vitrine onde o produto é exibido. Os sites canalizadores de mensagens atuam normalmente vinculados a um estabelecimento físico que lhes dá suporte material nos pedidos recebidos por vias eletrônicas. Nestas duas hipóteses, os sites devem ser considerados como meras extensões dos estabelecimentos físicos, de modo que se deve considerar que os serviços são prestados no estabelecimento do prestador. ${ }^{670}$

Os sites inteligentes, pela complexidade de atividades desenvolvidas no ambiente virtual, que em tudo se assemelham àquelas realizadas no mundo físico em uma loja ou estabelecimento tradicional, podem ser considerados como "estabelecimentos comerciais". Ou seja, quando as transações comerciais ocorrerem em um ambiente escolhido pelas partes, viabilizando a prestação de serviços ou o fornecimento de bens na própria rede (quando bens incorpóreos), ou por meio dela, relativamente a bens corpóreos, o site deve ser considerado como um novo estabelecimento do prestador. ${ }^{671}$ Outro aspecto relevante a ser considerado é a existência ou não de operadores deste site, ou de equipamentos necessários ao seu funcionamento. É certo que um site pode estar instalado em determinado equipamento hospedeiro, prescindindo de operadores fisicamente presentes para operacionalizá-los, podendo estes estar em outras cidades e, até mesmo, em outro país.

${ }^{669}$ Cf. GRECO, Marco Aurélio, Estabelecimento Tributário e Sites na Internet, in LUCCA, Newton De e SIMÃO FILHO, Adalberto (coord.), Direito \& Internet - Aspectos Jurídicos Relevantes. São Paulo: Quartier Latin, $2^{a}$ ed., 2005, pp. 341/342.

${ }^{670}$ Cf. Idem, ibidem, pp. 341/342.

${ }^{671}$ Cf. Idem, ibidem, p. 342. 
Neste sentido, o conceito de "estabelecimento permanente" adotado nas convenções internacionais, de que tratamos no item 3.8, exige um determinado grau de "presença" num dado local para sua configuração. ${ }^{672}$

Em trabalho a respeito do aspecto espacial da incidência do ISS nos serviços prestados via Internet, Drigo da Silva estabeleceu uma correlação entre um site de prestadores de serviços, que estão agrupados no DPN ${ }^{673}$ “.com”, e determinado número de Cadastro Nacional de Pessoa Jurídica - CNPJ da Secretaria da Receita Federal e também um endereço físico, dados que devem ser declarados obrigatoriamente no registro de um domínio. ${ }^{674}$

A Resolução CGI.br/RES/2008/008/P, de 28 de novembro de 2008, estabelece em seu artigo $4^{\circ}$, para a efetivação do registro de nome de domínio, a obrigatoriedade do fornecimento de diversos dados para as pessoas jurídicas, entre eles, o número do CNPJ, um endereço físico e um número de telefone, dados obrigatórios para o registro de um domínio. ${ }^{675}$

Desta forma, considerando a legislação vigente à época, o Decreto-lei $\mathrm{n}^{\mathrm{o}}$ 406/68, que também estabelecia como regra para o critério espacial do ISS o local do “estabelecimento prestador", concluiu o autor que o critério legal poderia ser mantido, propondo que se vinculasse o "estabelecimento virtual" àquele estabelecimento físico do titular do domínio sob o qual se encontra registrado o site ou e-mail.

Deu-se, portanto, roupagem nova ao velho critério do "estabelecimento prestador" consagrado pela legislação nacional, alterando-se os requisitos configuradores do estabelecimento, no caso de tratar-se de serviços prestados via Internet, consignando que seria considerado como "estabelecimento prestador" aquele local declarado para a inscrição do domínio. Saliente-se que, à época em que foi escrito o artigo, a lei complementar vigente não contemplava a definição nem os elementos configuradores da expressão "estabelecimento prestador", de modo diverso à legislação atualmente em vigor.

${ }^{672}$ Cf. Cf. GRECO, Marco Aurélio, op. cit. (nota 669), p. 342.

${ }^{673}$ DPN - Domínio de Primeiro Nível com a extensão “.com” agrupa os sites, ou domínios, cujos titulares estejam envolvidos com atividades comerciais.

${ }^{674}$ Cf. SILVA, Emerson Drigo da, Aspecto Espacial da Incidência do ISS sobre os Serviços prestados via Internet, in Internet - O Direito na Era Virtual. SCHOUERI, Luis Eduardo, organizador. 2a . ed. Rio de Janeiro: Forense, 2001, pp. 178-181.

675 No referido artigo, o autor menciona a Resolução $\mathrm{n}^{\circ} 001 / 98$, de 15.04.1998, que foi revogada pela Resolução 008, de 28.11.2008. Disponível em: <http://www.cgi.br/regulamentacao/resolucao2008-

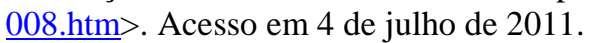


O próprio autor reconhece as limitações do critério proposto e conclui que "o critério não resolve, sozinho e de forma completa, todas as situações que podem decorrer dessa "nova" modalidade de prestação de serviço". ${ }^{676}$ A aplicação do critério exigiria, segundo o próprio autor, uma "eficiente comunicação entre os diversos municípios brasileiros", o que sabemos ser uma utopia quando falamos em mais de 5.500 entes absolutamente distintos em termos econômicos ou mesmo tecnológicos.

Além disto, bastaria o prestador de serviços manter o registro de seu domínio em outro país para que não fosse alcançado pela tributação do ISS, criando desta forma "paraísos fiscais virtuais."

Desta forma, com a aplicação do critério que consigna como “estabelecimento prestador" o estabelecimento físico para fins do registro do domínio da Internet, seriam alcançados pela tributação do ISS somente aqueles prestadores de serviço estabelecidos em território brasileiro e que mantivessem seus meios virtuais registrados junto ao órgão competente.

\subsection{Critério doutrinário: Atividade-Meio e Atividade-Fim}

A complexidade dos fatos envolvidos numa relação jurídica de prestação de serviço, considerada fundamentalmente como uma obrigação de "fazer", pode envolver, simultaneamente, uma obrigação de "dar", o que se traduz num obstáculo à definição pela incidência de determinados tributos sobre tais hipóteses. A mera presença de um esforço humano não significa a garantia de que tal atividade represente um "fazer" e, portanto, suscetível à incidência do ISS, podendo ocorrer conflito de competência relativo à incidência do ICMS e do IPI. ${ }^{677}$

Além disto, muitas destas prestações de serviço desenvolvem-se de maneira fragmentada, em etapas, que por vezes envolvem mais de um Município. Tal circunstância pode ocorrer, por exemplo, na atividade de consultoria, em que há, necessariamente, atos preparatórios de levantamento para o desenvolvimento do serviço em si. Nestes casos, de regra, há dificuldade de se precisar qual o ente político detentor da competência para constituir o crédito relativo a tais situações.

${ }^{676}$ SILVA, Emerson Drigo da, op. cit. (nota 674), p.185.

${ }^{677}$ Cf. BAPTISTA, Marcelo Caron, op. cit. (nota 177), pp. 282-283. 
É que as etapas intermediárias, necessárias para atingir a prestação de serviço em si, com ela não se confundem. Neste sentido, Barreto define "atividades-meio" como as "etapas necessárias à consecução do objetivo desejado". 678

Elucida o autor que o ISS, pela sua própria natureza, comporta desdobramentos que podem extrapolar o âmbito de um Município, levando à ocorrência de conflitos entre Municípios, que pretendem tributar etapas do desenvolvimento do serviço, cuja solução estaria na identificação precisa da atividade final objeto do fato jurídicotributário.

Portanto, para as situações em que o conflito ocorre em relação àqueles serviços que se desdobram em etapas ou tarefas, a doutrina criou o critério da atividademeio e atividade-fim como solução. Neste sentido, Aires F. Barreto nos ensina que

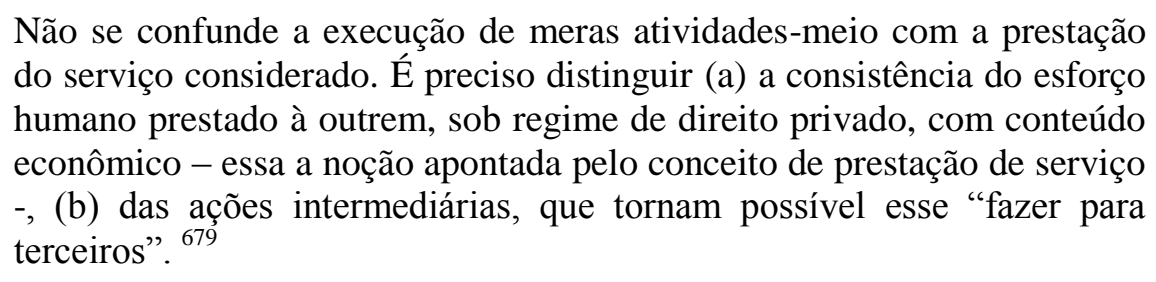

Ou seja, as etapas intermediárias de um serviço são "absorvidas" pela atividade principal, já que aquelas têm como função somente viabilizar a realização desta, além do que, seu custo estaria inserido no preço total do serviço. A pretensão do tomador de serviço somente é satisfeita por completo mediante a entrega ou fruição do negócio jurídico-fim, avençado com o prestador concluído.

As atividades-meio também estão presentes nos fatos jurídicos relativos ao ICMS, já que "toda aquisição de mercadoria envolve algum serviço: estacionamento para o cliente, manobrista, atendimento, cafezinho, transporte, etc., mas que são atividadesmeio para a derradeira atividade-fim que é vender mercadoria". 680

Relevante para a identificação deste comportamento-fim pactuado entre o tomador e o prestador é a natureza da prestação pretendida, que pode ser aferida pela

678 BARRETO, Aires F., ISS - Organização e Execução de Pacotes Turísticos, inclusive de Viagens Marítimas Temáticas - Local da Prestação dos Serviços - Navios podem ser Considerados como "Estabelecimento Prestador" para Fins de Incidência Tributária - Base de Cálculo dos Serviços de Organização e Execução de Pacotes Turísticos, Revista Dialética de Direito Tributário, São Paulo, Dialética, $\mathrm{n}^{\circ} .165$, p. 121.

${ }^{679}$ Idem, op. cit. (nota 613), p. 355.

${ }^{680}$ SANTI, Eurico Marcos, op. cit. (nota 483), p. 27. 
finalidade do contrato firmado entre as partes. ${ }^{681}$ A interpretação do contrato pactuado desvenda com precisão a "prestação-fim", que define a natureza jurídica da relação obrigacional, podendo todas as outras etapas ou atos ser considerados como meras "atividades-meio", absorvidas por aquela tida como principal.

\subsection{A Jurisprudência relativa ao Critério Espacial após a $\mathbf{L C} \mathbf{n}^{\circ}$ $116 / 2003$}

Antes da edição da Lei Complementar n 116/03, a definição do local da prestação de serviço, para fins de incidência do ISS, tinha como base legal o Decreto-lei ${ }^{\circ}$ 406/68, lei complementar no sentido material. Sob a égide daquele diploma, o STJ Superior Tribunal de Justiça, que é o órgão habilitado por nosso sistema normativo para "dizer o direito" relativamente ao tema, reiteradamente considerava competente para exigir o tributo aquele Município onde se executou a prestação do serviço.

O Decreto-lei $n^{\circ} 406 / 68$ também elegeu como regra para o critério espacial da hipótese o local do estabelecimento prestador, ou da sede, no entanto, não consignava a definição da expressão, o que acabou por trazer várias interpretações e orientações divergentes em relação ao assunto. Vejamos a dicção do art. 12:

Art 12. Considera-se local da prestação do serviço:

a) o do estabelecimento prestador ou, na falta de estabelecimento, o do domicílio do prestador;

b) no caso de construção civil o local onde se efetuar a prestação.

c) no caso do serviço a que se refere o item 101 da Lista Anexa, o Município em cujo território haja parcela da estrada explorada.

Com o advento da Lei Complementar $n^{\circ} 1162003$, que atribuiu a competência para o Município da sede do estabelecimento prestador do serviço (art. $3^{\circ}$ ), vem se firmando no STJ a posição de que o ISS, nos termos do disposto nos arts. $3^{\circ}$ e $4^{\circ}$ da LC 116/03, é devido no local do estabelecimento do prestador, conforme acórdão colacionado:

RECURSO ESPECIAL $\mathrm{N}^{\circ} 1.195 .844$ - DF (20100097356-3). TRIBUTÁRIO. ISS. LEI COMPLEMENTAR N ${ }^{\circ}$ 116/03. SERVIÇO DE INFORMÁTICA. COMPETÊNCIA PARA SUA COBRANÇA. FATO 
GERADOR. LOCAL DO ESTABELECIMENTO DO PRESTADOR. PRESENÇA DE UNIDADE ECONÔMICA OU PROFISSIONAL.

1. De acordo com os artigos $\underline{3^{\circ}}$ e $\underline{4}^{\circ}$ da Lei Complementar $n^{\circ} \underline{116} / 03$, conclui-se que a municipalidade competente para realizar a cobrança do ISS é a do local do estabelecimento prestador dos serviços, considerandose como tal a localidade em que há uma unidade econômica ou profissional, isto é, onde a atividade é desenvolvida, independentemente de sua denominação.

2. Ocorre que, no presente caso, o Tribunal a quo, em seu voto revisor, considerou que os serviços de informática foram prestados na sede da instituição financeira, localizada em Brasília, sendo disponibilizados técnicos residentes para a manutenção da solução durante o período, caracterizando uma unidade econômica ou profissional no âmbito do Distrito Federal, o que legitima esse ente estatal para a cobrança do ISS.

3. Para infirmar o acórdão recorrido, neste ponto, faz-se necessário o revolvimento de matéria fático-probatória, o que é inviável em sede de recurso especial pelo óbice do enunciado n. 7 da Súmula desta Corte.

4. Recurso especial parcialmente conhecido e, nessa parte, não provido. ${ }^{682}$ (g.n.)

No entanto, mesmo sob o manto da atual orientação do STJ, a análise da configuração de um “estabelecimento prestador” deve ser casuística, posto que comporta nuanças. No julgamento do REsp No 1.195.844 sob análise, o STJ considerou como estabelecimento prestador aquele do tomador dos serviços de informática. Os serviços foram prestados na sede de uma instituição financeira, localizada em Brasília, na qual a prestadora disponibilizou técnicos residentes para a manutenção da solução durante o período, considerando o Tribunal que, desta forma, caracterizou-se uma unidade econômica ou profissional no âmbito do Distrito Federal, que legitimou esse ente político para a cobrança do ISS, e não aquele aonde se localiza o estabelecimento prestador da empresa de informática.

Vejamos o trecho final do voto do Ministro relator:

No presente caso, o Tribunal a quo, em seu voto revisor, considerou que os serviços de informática foram prestados na sede da instituição financeira, localizada em Brasília, sendo disponibilizados técnicos residentes para a manutenção da solução durante $\mathrm{o}$ período, caracterizando uma unidade econômica ou profissional no âmbito do Distrito Federal, o que legitima esse ente estatal para a cobrança do ISS.

Confira-se o seguinte excerto do acórdão recorrido (fls. 349):

Nesse aspecto, e pela prova dos autos, em especial o contrato $\mathrm{n}^{\circ}$ 2006.86160202 (fls. 40/59), verifica-se que a Apelante foi contratada pelo Banco do Brasil para prestar serviços de informática na sede da

${ }^{682}$ No mesmo sentido REsp n ${ }^{\circ}$ 1.160.253-MG, Relator Min. Castro Meira. DJe 19.08.2010. Disponível em: <https://ww2.stj.jus.br/revistaeletronica/Abre_Documento.asp?sSeq=988538\&sReg=200901880868\&sDa

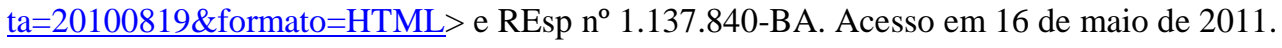


instituição financeira, localizada em Brasília, Distrito Federal, obrigandose, inclusive, a disponibilizar técnicos residentes para a manutenção da solução durante o período. Assim, pode-se concluir que a Apelante dispõe de uma unidade econômica ou profissional no âmbito do Distrito Federal, em consonância com o artigo 4 . $^{\circ}$ da LC 1162003.

Portanto, considerou aquele Tribunal que a existência "temporária ou permanente" de empregados/contratados do prestador de serviço no local da prestação de serviço constitui-se em sinal de exteriorização da representação de uma "unidade econômica ou profissional" do prestador do serviço e que, portanto, pode ser configurado como "estabelecimento prestador". Esse mesmo entendimento também foi acatado pelo STJ quando do julgamento do REsp $n^{\circ} 1.160 .253$, também da $2^{\text {a }}$ Turma do STJ.

Desta forma, o conceito adotado pelo STJ prescinde de alguns elementos objetivos exigidos pela Lei Complementar $n^{\circ} 116 / 03$, como a base física e a estrutura organizacional, concentrando a configuração somente no elemento subjetivo, considerando que a alocação de pessoal especializado no estabelecimento do tomador, ainda que temporária, era suficiente para a configuração do "estabelecimento prestador", aproximando-se neste diapasão daquele conceito de "estabelecimento permanente" adotado pelas convenções internacionais com base no Modelo da OCDE.

Impende registrar que o Superior Tribunal de Justiça julgou em 14.10.2009 o Recurso Especial $n^{\circ}$ 1.117.121/SP, em que a competência para a cobrança do ISS foi analisada sob a égide da Lei Complementar $n^{\circ} 116 / 2003$. O fulcro do processo era o serviço de construção civil, que constitui, da mesma forma que a norma geral anterior, exceção em relação à regra geral do "estabelecimento prestador", o local da prestação do serviço. Vejamos o teor da ementa:

TRIBUTÁRIO - ISS - PRESTAÇÃO DE SERVIÇO - CONSTRUÇÃO CIVIL - PROJETO, ASSESSORAMENTO NA LICITAÇÃO E GERENCIAMENTO DA OBRA CONTRATADA - COMPETENNCIA DO MUNICÍPIO ONDE SE REALIZOU O SERVIÇO DE CONSTRUÇÃO - CONTRATO ÚNICO SEM DIVISÃO DOS SERVIÇOS PRESTADOS.

1. A competência para cobrança do ISS, sob a égide do DL 406/68 era o do local da prestação do serviço (art. 12), o que foi alterado pela LC 116/2003, quando passou a competência para o local da sede do prestador do serviço $\left(\operatorname{art.~} 3^{\circ}\right)$.

2. Em se tratando de construção civil, diferentemente, antes ou depois da lei complementar, o imposto é devido no local da construção (art.12, letra "b" do DL 406/68 e art.3", da LC 116/2003).

3. Mesmo estabeleça o contrato diversas etapas da obra de construção, muitas das quais realizadas fora da obra e em município diverso, onde 
esteja a sede da prestadora, considera-se a obra como uma universalidade, sem divisão das etapas de execução para efeito de recolhimento do ISS. (g.n.)

$[\ldots]$

Vale dizer, em se tratando de construção civil, antes ou depois da $\mathrm{LC} \mathrm{n}^{\circ}$ 116/2003, o imposto é devido no local da obra, de modo que entendemos que o julgado não representa um paradigma relativo ao critério espacial do ISS. A relevância do caso, no entanto, reside na admissão de que a LC $\mathrm{n}^{\circ}$ 116/2003 alterou a competência para a cobrança do ISS em relação ao que determinava o DL $n^{\circ} 406 / 68$, reconhecendo a regra geral do "estabelecimento permanente".

Em seu voto, a Ministra Eliana Calmon ressalta que, com a edição da Lei Complementar $\mathrm{n}^{\circ} 116 / 2003$,

houve alteração de entendimento em relação ao local de recolhimento do $\underline{\text { ISS sobre os serviços prestados, porque foi profundamente alterado o }}$ artigo 12 do Decreto-Lei $\mathrm{n}^{\circ}$ 406/68, revogado pelo novo diploma que, atendendo à reivindicação dos contribuintes, consignou o lugar da sede da empresa como o local de recolhimento do ISS. (g.n.) ${ }^{683}$

683 Trecho do voto da Min. Relatora Eliana Calmon no REsp $\mathrm{n}^{\circ}$ 1.117.121. Disponível em: <https://ww2.stj.jus.br/revistaeletronica/ita.asp?registro=200900908260\&dt_publicacao=29/10/2009>. Acesso em 16 de maio de 2011. 


\section{DA TRIBUTAÇÃO DO COMÉRCIO ELETRÔNICO NO BRASIL}

O comércio eletrônico que, como vimos, envolve operações de venda de bens e serviços, impacta diretamente nos tributos sobre o consumo no Brasil, em especial o ISS e o ICMS, que surgiram como um desdobramento do IVA - Imposto sobre Valor Agregado em dois tributos: um onerando a circulação de mercadorias (bens materiais) e outro tributando a venda de bens não considerados mercadorias (serviços).

Em termos tributários, a relativização das condições de tempo e lugar que ocorre nas operações de "comércio eletrônico" influenciará diretamente aqueles fatos jurídicos eleitos pelo legislador constituinte para fazer incidir, em especial, os impostos sobre o consumo. A estrutura lógica da norma jurídico-tributária será afetada diretamente em dois aspectos da regra-matriz de incidência do tributo que incidirá na operação: o critério espacial, já que o fato pode ocorrer simultaneamente em mais de um local, ou mesmo num espaço virtual, e o critério material em face da dificuldade de se distinguir com nitidez nestas operações qual é o fato jurídico tributário que está sendo desenvolvido compra e venda de mercadorias, prestação de serviços ou operações mistas, entre outras, e da "crise" dos conceitos clássicos utilizados. 
Os números do comércio eletrônico demonstram que o faturamento nesta modalidade de vendas saltou de 540 milhões de reais, em 2001, para 18,7 bilhões de reais, em 2011, obtendo crescimento anual entre 76\% (2006) e 26\% (2011), nos últimos dez anos. Impulsionada ainda pela melhoria nos indicadores de emprego e renda da população brasileira, a modalidade facilita o acesso das camadas sociais antes excluídas a recursos eletrônicos. ${ }^{684}$

Os benefícios trazidos pelas novas tecnologias para os cidadãos, no entanto, trouxeram também distorções no equilíbrio econômico entre as unidades federadas, já que as sedes das grandes empresas do setor estão sediadas nos Estados mais ricos e desenvolvidos. É que nosso sistema privilegia o princípio da origem nos casos de envio de mercadorias de um Estado para outro quando os adquirentes não são contribuintes do imposto.

Segundo dados do CONFAZ, em pesquisa relativa a vendas interestaduais, inclusive eletrônicos, realizadas a não contribuintes como pessoas físicas, Administração Pública, hospitais, bancos, construtoras e outros, são os seguintes os valores dos superávits obtidos por Estados no comércio interestadual no período entre janeiro e maio de 2011: Estado de São Paulo 242 milhões de reais, Santa Catarina 55,3 milhões de reais, Rio de Janeiro 45,8 milhões de reais, Goiás 40,5 milhões de reais, Tocantins 5,6 milhões de reais e Espírito Santo 2,9 milhões de reais. Ainda segundo a pesquisa, todos os outros Estados tiveram déficit no comércio interestadual, porque são importadores de mercadorias, inclusive por meios eletrônicos.

Entre os maiores deficitários, despontam o Estado da Bahia com 68,01 milhões de reais, o Distrito Federal com 67,6 milhões de reais e Minas Gerais com 63,3 milhões de reais, entre outros.

Ressalte-se que o Estado de Santa Catarina, superavitário no sistema interestadual do ICMS, alega haver uma perda de 29 milhões de reais com a atual forma de tributação de ICMS no comércio eletrônico. ${ }^{685}$

Segundo Marco Aurélio Greco, uma das primeiras consequências da mobilidade do consumo e dos agentes econômicos no comércio eletrônico "é a constatação de que a nossa legislação não está preparada para captar a capacidade contributiva

\footnotetext{
684 Cf. Parecer da Comissão de Constituição e Justiça de Cidadania, Disponível em: <http://www6.senado.gov.br/mate-pdf/98234.pdf $>$. Acesso em 2 de novembro de 2012.

${ }^{685}$ Cf. Ibidem. Acesso em 2 de novembro de 2012.
} 
manifestada através destes novos meios”. ${ }^{686}$ Esta dificuldade adviria da insuficiência de vários conceitos clássicos que estariam em "crise", como a definição de "mercadoria" e "serviços", assim como da definição do "local da prestação de um serviço", ou do conceito de "estabelecimento prestador".

No sentir de Daniela Braghetta, as regras de tributação contempladas na Constituição Federal de 1988, relativas ao comércio e serviços, abrangeriam as operações contidas no comércio eletrônico e seriam suficientes e adequadas a esta nova forma de realizar operações mercantis e prestar serviços. ${ }^{687}$ Desta forma, caberia à legislação infraconstitucional que surgir para regulamentar tais operações, coadunar-se com o texto constitucional, respeitando os limites ali estabelecidos.

Os fatos jurídicos eleitos pelo legislador para estabelecer os vínculos abstratos tributários devem ocorrer, necessariamente, em determinadas condições de tempo e espaço. Desta forma, nos fatos jurídicos de prestar serviço, sobre os quais incide o ISS, o critério espacial, em regra, é o local do "estabelecimento prestador" ou, em alguns casos, o local em que é prestado o serviço, sendo o critério temporal o momento em que é prestado o serviço.

Tais critérios condicionam o liame jurídico, a relação que se estabelecerá no consequente da norma jurídico-tributária, definindo, entre outras coisas, qual será o ente titular do direito subjetivo de exigir o tributo incidente sobre determinado fato jurídico tributário.

Desta forma, a relativização das condições de tempo e de lugar, que ocorre no "comércio eletrônico", refletirá na relação jurídica que se estabelecerá no prescritor da norma jurídico-tributária. Vale dizer, se existe dificuldade de se determinar o local e o tempo em que ocorreu o fato imponível, surgirão situações de conflito entre duas ou mais pessoas políticas, relativas ao direito subjetivo de tributar tais fatos.

Neste sentido, tomando como fundamento a classificação do "comércio eletrônico" em direto e indireto, Emerenciano concluiu em recente trabalho sobre o tema que nosso ordenamento jurídico, que é baseado em regras que consideram a natureza física e tangível dos produtos e que toma a identificação e a localização em pontos físico-

${ }^{686}$ Cf. GRECO, Marco Aurelio, op. cit. (nota 86), p. 52.

${ }^{687}$ Cf. BRAGHETTA, Daniela de Andrade, op. cit. (nota 87), pp. 137/138. 
geográficos como pressupostos, não abrangeria a singularidade dos negócios em bases digitais. $^{688}$

\subsection{As Primeiras Diretrizes: a Tributação do Software}

No Brasil, a questão da tributação do software reativou a polêmica da repartição da competência impositiva do Imposto sobre Valor Agregado - IVA entre Estados e Municípios, ao mesmo tempo em que inaugurou os debates a respeito da tributação de bens eletrônicos.

A questão foi submetida já em 1999 ao Supremo Tribunal Federal - STF, para que se pronunciasse sobre o tratamento tributário a ser dispensado ao software, visando a definir, desta forma, a competência impositiva disputada entre os Estados e os Municípios.

Sendo a "mercadoria" o "objeto material da norma de competência dos Estados", necessitava-se perquirir a natureza jurídica do software: mercadoria ou bem incorpóreo. A jurisprudência havia se pacificado no sentido de que o software "de prateleira", isto é, aquele programa do qual são comercializadas milhares de cópias, estaria abrangido pelo conceito de "mercadoria", desafiando, portanto, a incidência do ICMS Imposto sobre Circulação de Mercadorias. Já aquele software desenvolvido "sob encomenda", customizado para um caso específico, estaria no campo de tributação do Imposto sobre Serviços, ISSQN, de competência municipal.

No julgamento do RE 176.626-3/SP, apesar do recurso não ter sido conhecido, a discussão tornou-se paradigma para a questão, de modo que, nos recursos posteriores relativos ao assunto, cita-se o respectivo julgamento. A questão restou assim ementada pelo STF:

I. Recurso extraordinário :[...] II. RE: questão constitucional: âmbito de incidência possível dos impostos previstos na Constituição: ICMS e mercadoria. Sendo a mercadoria o objeto material da norma de competência dos Estados para tributar-lhe a circulação, a controvérsia sobre se determinado bem constitui mercadoria é questão constitucional em que se pode fundar o recurso extraordinário. III. Programa de computador ("software"): tratamento tributário: distinção necessária. Não tendo por objeto uma mercadoria, mas um bem incorpóreo, sobre as operações de "licenciamento ou cessão do direito de uso de programas de

${ }^{688}$ Cf. EMERENCIANO, Adelmo da Silva, op. cit. (nota 39), pp. 57, 154, 159, 161, 171 e 175. 
manifestou:

computador" "matéria exclusiva da lide", efetivamente não podem os Estados instituir ICMS: dessa impossibilidade, entretanto, não resulta que, de logo, se esteja também a subtrair do campo constitucional de incidência do ICMS a circulação de cópias ou exemplares dos programas de computador produzidos em série e comercializados no varejo - como a do chamado "software de prateleira" (off the shelf) - os quais, materializando o corpus mechanicum da criação intelectual do programa, constituem mercadorias postas no comércio. ${ }^{69}$

Em seu voto, o Ministro Ilmar Galvão, citando Rui Saavedra ${ }^{690}$, assim se

\begin{abstract}
"Diferentemente sucede" - assinala o autor "nas relações com o utilizador de um software standard, porque este vocaciona-se a ser comercializado junto de uma clientela potencialmente vasta: a propriedade do software em si, normalmente, nunca é cedida ao cliente, apenas um direito de uso não exclusivo. Isso não obsta a que se considere que o cliente adquire as 'manifestações físicas' do software, com todas as prerrogativas ligadas a esta propriedade, se a licença de uso lhe tiver concedido a título definitivo e por um preço. [...] o comerciante que adquire exemplares para revenda (bem como o industrial que os produz, acresça-se), mantendo-os em estoque ou expondo-os em sua loja, não assume a condição de licenciado ou cessionário dos direitos de uso que, em consequência, não pode transferir ao comprador: sua posição aí é a mesma de vendedor de livros ou de discos, que não negocia com os direitos do autor, mas com o corpus mechanicum de obra intelectual, que nele se materializa. Tampouco, a fortiori, a assume o consumidor final, se adquire um exemplar de programa para dar de presente a outra pessoa."
\end{abstract}

Como se vê, mesmo que o software dito "de prateleira" envolva essencialmente um direito de licença de uso, o que foi relevante para definir a incidência do ICMS é a existência de um corpus mechanicum (um meio físico) e a prevalência do caráter de "bem" do ponto de vista da relação mercantil entre o vendedor deste bem e seu adquirente.

A solução, no entanto, não se aplica à comercialização de software via download, em que não há propriamente um corpus mechanicum e em que prevalece o caráter de cessão de um "direito". Desta forma, considerando-se que o conceito de "mercadoria" pressupõe um meio físico, restringindo-se a bens "móveis e semoventes", a operação de download não se subsumiria ao conceito de mercadoria.

${ }^{689}$ RE 176.626-3/SP, Disponível em: 〈http://www.stf.jus.br/portal/jurisprudencia〉. Acesso em 24 de julho de 2012.

${ }^{690}$ Trecho do voto no RE 176.626-3. Rui Saveedra é autor da obra A Proteç̧ão Jurídica do Software e a Internet, escrito em 1999. 
No caso do fornecimento de conteúdo, porém, pode-se em alguns casos suscitar a incidência de ISS (exibição de filmes, execução de música, armazenamento de bens de qualquer espécie, assessoria ou consultoria de qualquer natureza - que inclui o fornecimento de dados e informações de qualquer natureza) ou de ICMS (serviços de comunicação). No sentir de José Eduardo Soares de Melo, o software seria um produto intelectual, estando, portanto, sujeito à cessão de direitos e não a operações de circulação. 691

Em 2003, com a edição da Lei Complementar n 116, o "licenciamento ou cessão de direito de uso de programas de computação" passou a constar expressamente do rol taxativo contido na Lista de Serviços anexa àquela lei, como se vislumbra do item 1.05 .

Em recente consulta sobre atividades incluídas no Simples Nacional, a Secretaria da Receita Federal definiu que o fornecimento de conteúdo pela Internet deve ser considerado um "serviço", sem que esclarecesse, contudo, se tal serviço seria tributável pelo ISS ou ICMS. Vejamos o teor da Consulta:

Processo de Consulta $n^{\circ}$ 263/10

Superintendência Regional da Receita Federal - SRRF / $9^{\text {a }}$ RF

Ementa: SIMPLES NACIONAL. INTERNET. OFERTA DE CONTEÚDO.

A receita obtida com a atividade de oferta de conteúdo, em portal da Internet, mediante pagamento mensal, constitui serviço tributado pelo Anexo III da Lei Complementar No 123, de 2006.

Dispositivos Legais: Lei Complementar $\mathrm{N}^{\circ} 123$, de 2006, art. 17, $\S 2^{\circ}$, art. $18, \S 5^{\circ}$-D, V, VI, $\S 5^{\circ}$-F.

ACÓRDÃO Processo Administrativo Fiscal.

CONSULTA. COMPETÊNCIA FEDERAL.

A RFB não tem competência para responder a processos de consulta sobre dúvidas quanto ao fato de determinado serviço ser ou não de comunicação, para fins de tributação pelo Simples Nacional.

Isso porque se trata de matéria de interesse exclusivamente estadual e municipal, porquanto essa dúvida repercute apenas na necessidade ou não de se fazer os ajustes de ICMS e ISS previstos no art. $18, \S 5^{\circ}$ - E, da Lei Complementar $\mathrm{N}^{\mathrm{o}}$ 123, de 2006.

Dispositivos Legais: Lei Complementar $\mathrm{N}^{\mathrm{o}} 123$, de 2006, art. 18, § $5^{\circ}$-E, art. 40; Resolução CGSN Nº 13, de 2007, art. $3^{\circ}, \S 1^{\circ}$.

MARCO ANTÔNIO FERREIRA POSSETTI - Chefe. ${ }^{62}$

${ }^{691}$ Cf. MELO, José Eduardo Soares, op. cit. (nota 590), p.19.

${ }^{692}$ Processo de Consulta no 263/10/ SRRF. Disponível em: 〈www.receita.fazenda.gov.br〉. Acesso em 24 de julho de 2012. 
Recentemente, o Supremo Tribunal Federal foi novamente instado a manifestar-se sobre a tributação do software, em sede de ADIN oposta à Lei $\mathrm{n}^{\circ} 7.098$ do Estado do Mato Grosso, cujo "tema central" era o artigo $2^{\circ}$ que determinava a incidência do ICMS sobre operações com programas de computador - software - "ainda que realizadas por transferência eletrônica de dados". Vejamos o trecho do acórdão proferido na análise da medida cautelar:

Ação Direta de Inconstitucionalidade. Direito Tributário. [...] 8. ICMS. Incidência sobre softwares adquiridos por meio de transferência eletrônica de dados $\left(\operatorname{art.~} 2^{\circ}, \S 1^{\circ}\right.$, item 6 , e art. $6^{\circ}, \S 6^{\circ}$, ambos da Lei impugnada). Possibilidade. Inexistência de bem corpóreo ou mercadoria em sentido estrito. Irrelevância. O Tribunal não pode se furtar a abarcar situações novas, consequências concretas do mundo real, com base em premissas jurídicas que não são mais totalmente corretas. O apego a tais diretrizes jurídicas acaba por enfraquecer o texto constitucional, pois não permite que a abertura dos dispositivos da Constituição possa se adaptar aos novos tempos, antes imprevisíveis. 9. Medida liminar parcialmente deferida, para suspender a expressão "observados os demais critérios determinados pelo regulamento", presente no parágrafo $4^{\circ}$ do art. 13, assim como o inteiro teor do parágrafo único do art. 22, ambos da Lei 7.098/98, do Estado de Mato Grosso. (g. n.) ${ }^{693}$

O Ministro Nelson Jobim em seu voto salientou que nenhuma diferença existe entre o conteúdo dos disquetes de prateleira que eram adquiridos à época em que se julgou o paradigma e o arquivo digital que é obtido por download via Internet, diretamente no site do fornecedor. Aduz o Ministro que a diferença fundamental encontra-se na forma de transferência do programa: ou transmite-se pelo sistema material, adquirindo o disquete ou CD em uma livraria, empresa, ou loja vendedora, ou se transmite de forma eletrônica, por meio de download dos arquivos diretamente no disco rígido de um computador.

E traz à discussão o fato de que a energia elétrica, que não é um sinal binário matemático, mas também não coincide com o conceito de bem corpóreo no sentido estrito da expressão, é tributável pelo ICMS, concluindo que a Constituição Federal trata a energia elétrica como mercadoria. Neste ponto, aduzindo que não se pode concluir que não houve uma aquisição somente porque não há "bem corpóreo", enfatiza que "começa a entrar em limites, ou seja, a linguagem utilizada no sistema da Constituição pelo ICMS começa a bater com sistemas modernos de comercialização, de transferências. O caminho é

693 ADI 1945-MT MATO GROSSO. MEDIDA CAUTELAR NA AÇÃO DIRETA DE INCONSTITUCIONALIDADE. Relator(a): Min. OCTAVIO GALLOTTI. Relator p/ Acórdão: Min. GILMAR MENDES. Julgamento: 26.05.2010. Disponível em: <http://www.stf.jus.br/portal/jurisprudencia >. Acesso em 7 de novembro de 2012. 
todo dessa forma, ou seja, vai-se utilizar cada vez mais esse sistema de inter-relações através da Internet." E finaliza considerando que "a prestação de serviços, inclusive, se produz hoje basicamente pela Internet" e que a transferência do serviço encomendado não é por sistema de disquete, mas por meio de download. (g. n.) ${ }^{694}$ Após pedido de vista para estudar o assunto, o Ministro concluiu que é possível a incidência do ICMS sobre a circulação de "mercadoria virtual", objeto que é, em realidade, linguagem matemática binária.

Para o Ministro, “a época hoje é de realização de negócios, operações bancárias, compra de mercadorias, acesso a banco de dados de informações, compra de músicas e vídeos e aquisição de programa de computador nesse ambiente digital".

No mesmo julgamento, o Min. Lewandowisky, após pedido de vista, constatou que a orientação jurisprudencial do STF não destoava da conclusão alcançada no XLVII Congresso Internacional de Direito Financeiro e Fiscal, promovido pela Internacional Fiscal Association - FIA, que se dedicou ao tema do tratamento tributário do software. Distinguiu-se naquele certame que a venda de "software de prateleira" (packaged software, standard program) equivale a uma venda de mercadoria, ao passo que o software customizado, desenvolvido para necessidades específicas, equivale a uma prestação de serviços.

Ao proferir seu voto, o Ministro Eros Grau se manifestou sobre a evolução dos conceitos constitucionais: "Lavou a minha alma o Ministro Gilmar Mendes dizer que a realidade altera o significado dos textos. Passei seis anos nesta Corte tentando dizer isto: o movimento da vida e da realidade é que dá o significado normativo dos textos".

Note-se que o Tribunal, ao admitir que incide o ICMS sobre softwares adquiridos por meio de transferência eletrônica de dados, ampliou o conceito de "mercadoria" anteriormente adotado por aquela Corte, fixando exegese que passa a englobar também bens incorpóreos. Sob o argumento de que as premissas jurídicas devem ser atualizadas em face das transformações ocorridas no "mundo real", propondo que os dispositivos constitucionais se adaptem às novas realidades, fez-se clara alusão a "tipos" e

${ }^{694}$ Trecho do voto do Min. Nelson Jobim na Medida Cautelar da ADin, p. 39. Disponível em: 〈http://www.stf.jus.br/portal/jurisprudencia〉. Acesso em 7 de novembro de 2012. 
não a "conceitos", relativamente àqueles signos constitucionais atributivos de competência aos entes federativos, conforme abordamos no item 4.2.5. ${ }^{695}$

\subsubsection{Imposto sobre o Consumo: a Origem e o Destino no Comércio Eletrônico}

A tributação das operações interestaduais é disciplinada pela Constituição Federal Brasileira, que estabelece os critérios aplicáveis às operações relativas ao Imposto sobre a Circulação de Mercadorias - ICMS, cuja competência impositiva foi atribuída aos Estados. Na sistemática criada, as alíquotas são diferenciadas em função do destinatário das operações: quando os bens ou serviços destinam-se a consumidor final de outro Estado não contribuinte do imposto, a alíquota do ICMS será aplicável a alíquota interna do Estado do qual as mercadorias procedem, sendo o imposto integralmente devido neste local (origem). Já nas operações destinadas a consumidores contribuintes do imposto, a parcela correspondente à diferença entre a alíquota interna e a interestadual é devida ao Estado de destino das mercadorias ou serviços.

Contribuinte do ICMS, nos termos do art. $4^{\circ}$ da Lei Complementar $n^{\circ}$ 87/1996, é “qualquer pessoa, física ou jurídica, que realize, com habitualidade ou em volume que caracterize intuito comercial, operações de circulação de mercadoria ou prestações de serviços de transporte interestadual e intermunicipal e de comunicação, ainda que as operações e as prestações se iniciem no exterior”. Verifica-se que a norma geral vigente exige dois aspectos para a configuração de contribuinte: a habitualidade e a realização de compras em volume que denote intuito comercial.

O denominado "diferencial de alíquota" é o valor do imposto correspondente à diferença entre a alíquota interna e a interestadual, que surge nas operações em que o adquirente dos bens ou serviços é contribuinte do ICMS e está domiciliado em Estado diverso daquele em que a mercadoria foi adquirida.

Esta sistemática de alíquotas diferenciadas visa a dar cumprimento ao disposto no art. $155, \S 2^{\circ}$, I da Constituição Federal, que submete o ICMS ao princípio da não-cumulatividade. Para efetivar o princípio, “exige-se, em cada elo da cadeia de

${ }^{695}$ Trecho do voto do Min. Lewandowski na Medida Cautelar da ADin pp. 69/70. Disponível em: $\langle$ http://www.stf.jus.br/portal/jurisprudencia $>$. Acesso em 7 de novembro de 2012. 
produção ou circulação, a compensação entre a relação do direito ao crédito (nascida com a entrada jurídica do bem) e a relação jurídico-tributária (que nasce com a saída da mercadoria)". 696

Os Estados menos desenvolvidos foram favorecidos neste sistema de apropriação de créditos na entrada jurídica da mercadoria, com o estabelecimento de alíquotas diferenciadas por meio da Resolução $n^{\circ} 22$ de 1989, conforme se verifica no artigo $1^{\circ}$ :

Art. $1^{\circ}$. A alíquota do Imposto sobre Operações Relativas à Circulação de Mercadorias e sobre Prestação de Serviços de Transporte Interestadual e Intermunicipal e de Comunicação, nas operações e prestações interestaduais, será de doze por cento.

Parágrafo único. Nas operações e prestações realizadas nas Regiões Sul e Sudeste, destinadas às Regiões Norte, Nordeste e Centro-Oeste e ao Estado do Espírito Santo, as alíquotas serão:

I - em 1989, oito por cento;

II - a partir de 1990, sete por cento. ${ }^{697}$

Note-se que, sempre que a mercadoria sair de uma região menos favorecida, assim definidos os Estados das regiões Norte, Nordeste e Centro-Oeste e o Estado do Espírito Santo, incide o ICMS à alíquota de 12\% na origem e 5\% no destino. Se, no entanto, a mercadoria provém de um dos Estados considerados mais favorecidos (regiões Sul e Sudeste, exceto o Estado do Espírito Santo) incide o imposto à alíquota de $7 \%$ na origem e $10 \%$ no consumo caso seja destinado ao Norte, Nordeste, Centro Oeste e Espírito Santo, ou $12 \%$ na origem e $5 \%$ no consumo se for destinado ao Sul, Sudeste (exceto Espírito Santo). Ainda por determinação constitucional, as alíquotas internas não poderão ser inferiores às previstas para as operações interestaduais fixadas pelo Senado, garantindo que os Estados menos favorecidos recebam a diferença entre as duas alíquotas.

O comércio eletrônico influenciou diretamente no sistema de créditos do ICMS, já que os Estados mais favorecidos, que concentram os maiores centros de distribuição, atingem diretamente por meios virtuais os consumidores finais dos outros Estados, eliminando os intermediários que, sendo contribuintes do ICMS, dariam ao Estado do destino o direito ao crédito do diferencial de alíquota. É desta perda de mercado

${ }^{696}$ CARVALHO, Paulo de Barros, op. cit. (nota 19), p. 649.

697 Art. $1^{\circ}$ da Resolução $\mathrm{n}^{\circ} 22$ de 1989. Disponível em: <http://www6.senado.gov.br/legislacao/ListaPublicacoes.action?id=132875 >. Acesso em 22 de novembro de 2012. 
e de arrecadação que se ressentem os Estados e que os levou à edição do Protocolo ICMS $\mathrm{n}^{\circ} 21$, que passaremos a analisar.

\subsection{A Regulamentação do ICMS Incidente no Comércio Eletrônico}

O Protocolo ICMS n ${ }^{\circ} 21^{698}$, em vigor desde $1^{\circ}$ de maio de 2011, determina a partilha do Imposto sobre Circulação de Mercadorias e Serviços - ICMS gerado a partir da venda de bens ou mercadorias destinados a consumidores que estejam localizados em unidade federada destinatária diferente daquela em que se encontra o vendedor, entre os dois Estados envolvidos, equiparando o consumidor final à contribuinte do imposto.

Com fundamento no referido protocolo, assinado pelos Estados do Norte, Nordeste e Centro-Oeste, os produtos adquiridos via comércio eletrônico destinados aos mencionados Estados passaram a ser tributadas pelo ICMS em suas fronteiras.

$\mathrm{O}$ incremento das vendas por meio do comércio eletrônico e telemarketing causou a vários Estados da Federação, em especial aqueles do Norte, Nordeste e Centro-Oeste, perdas significativas na arrecadação do ICMS; conforme vimos, nos termos da legislação vigente, a incidência do imposto ocorre no Estado de origem da mercadoria. Uma das considerações do referido protocolo aduz que

o aumento dessa modalidade de comércio, de forma não presencial, especialmente as compras por meio da internet, telemarketing $\mathrm{e}$ showroom, deslocou as operações comerciais com consumidor final, não contribuintes de ICMS, para vertente diferente daquela que ocorria predominante quando da promulgação da Constituição Federal de 1988. (g.n.) ${ }^{699}$

Por outro giro, a assinatura do Protocolo ICMS $\mathrm{n}^{\circ} 21$ deu-se em decorrência do aumento das vendas não presenciais nos últimos anos, fato que fez vários Estados da Federação, em especial os do Norte e do Nordeste, detectarem significativa

${ }^{698}$ Os protocolos não se confundem com os convênios. O convênio é um acordo entre os Estados-membros e ocorre quando é homologado por todos e para todos possui a mesma validade; já o protocolo é um acordo realizado entre dois ou mais Estados-membros, desde que não interfiram na autonomia dos outros Estados não signatários do concerto. Os protocolos estão previstos no art. 38 do CONVÊNIO ICMS 133/97, que aprova o Regimento do CONFAZ.

${ }^{699}$ Disponível em: <http://www.fazenda.gov.br/confaz/confaz/protocolos/icms/2011/pt021_11.htm>. Acesso em 31 de outubro de 2012. 
perda na arrecadação do ICMS, uma vez que a legislação em vigor dispõe que a incidência do imposto ocorre no Estado de origem da mercadoria.

São signatários do Protocolo ICMS n ${ }^{\circ} 21$ dezoito Estados e o Distrito Federal: Acre, Alagoas, Amapá, Bahia, Ceará, Espírito Santo, Goiás, Maranhão, Mato Grosso, Mato Grosso do Sul, Pará, Paraíba, Pernambuco, Piauí, Rio Grande do Norte, Roraima, Rondônia e Sergipe. Por óbvio, o Estado de São Paulo e mais sete Estados do Sul e Sudeste não assinaram o referido Protocolo.

No entanto, nos termos do disposto no parágrafo único da Cláusula primeira do referido documento, "a exigência do imposto pela unidade federada destinatária da mercadoria ou bem, aplica-se, inclusive, nas operações procedentes de unidades da Federação não signatárias do protocolo".

$\mathrm{Na}$ prática, as empresas dos Estados não signatários vêm sendo bitributadas para poder entregar as mercadorias nos Estados do Norte e Nordeste, já que se exige o comprovante do recolhimento do imposto na fronteira do Estado destinatário da mercadoria. ${ }^{700}$

O Regimento Interno do CONFAZ permite que dois ou mais Estados e o Distrito Federal celebrem entre si Protocolos para estabelecer procedimentos comuns, visando à implementação de políticas físcais. Mas não lhes autoriza a alterar a própria sistemática do imposto disposta na Constituição Federal. As operações que destinem bens e serviços para consumidor final localizado em outro Estado estão disciplinadas no inciso VII do parágrafo $2^{\circ}$ do art. 155 da Constituição Federal. Estabelece a norma constitucional as alíquotas de ICMS a serem aplicadas, distinguindo-as de acordo com a classificação do destinatário do produto, conforme seja contribuinte do imposto (alínea "a") ou não contribuinte (alínea "b”).

Em face da situação, no dia $1^{\circ}$ de julho de 2011, a Fecomercio SP ajuizou junto ao Supremo Tribunal Federal - STF, por intermédio da Confederação Nacional do Comércio - CNC, a Ação Direta de Inconstitucionalidade $\mathrm{n}^{\circ} 4628$, impugnando o Protocolo ICMS 21/2011. Na petição da ADI, aduz a entidade:

Indiscutível que o Brasil e o mundo mudaram muito desde a promulgação da Constituição de 1988. Assim também ocorreu com as formas de se adquirir um produto ou serviço, sendo a internet um instrumento ainda

${ }^{700}$ Cf. 〈http://www.fecomercio.com.br/arquivos/arquivo/juridico/aj1461117ba0791.pdf〉. Acesso em $31 \mathrm{de}$ outubro de 2012. 
relativamente novo e crescente que alterou em muito a forma ordinária de se fazer compras. Todavia, se este novo modo de se adquirir bens ou serviços aumenta eventuais desigualdades regionais por gerar impacto negativo na arrecadação de ICMS de alguns estados da Federação, que seja alterada a Constituição por seu instrumento apropriado (Emenda) e que não se tente alterá-la de forma inaceitável e flagrantemente inconstitucional". 701

Por outro giro, ainda que se considere justo o pleito dos Estados consumidores contra o sistema tributário vigente, é indiscutível que os meios adotados são abusivos e eivados de vícios. Segundo a Fecomercio, o Protocolo 21 é inconstitucional, por ofensa ao disposto no Art. 155, II, parágrafo 2, VII, “b”, da Constituição Federal:

Art. 155. Compete aos Estados e ao Distrito Federal instituir impostos sobre:

[...]

II - operações relativas à circulação de mercadorias e sobre prestações de serviços de transporte interestadual e intermunicipal e de comunicação, ainda que as operações e as prestações se iniciem no exterior;

[...]

$\S 2 .^{\circ} \mathrm{O}$ imposto previsto no inciso II atenderá ao seguinte:

[...]

VII - em relação às operações e prestações que destinem bens e serviços a consumidor final localizado em outro Estado, adotar-se-á:

[...]

b) a alíquota interna, quando o destinatário não for contribuinte dele. (g.n.)

A dicção do texto constitucional é clara: nas operações e prestações que destinem bens e serviços a consumidor final não contribuinte, localizado em outro Estado, a alíquota do ICMS aplicável será a alíquota interna do Estado do qual as mercadorias procedem, sendo o imposto integralmente devido neste local (origem). Somente nas operações destinadas a consumidores finais contribuintes do imposto é que a parcela correspondente à diferença entre a alíquota interna e a interestadual será devida ao Estado de destino.

Vale dizer: por expressa determinação constitucional, a partilha do ICMS entre o Estado de origem dos bens e serviços e o Estado destinatário só ocorre quando, e se, a operação interestadual for efetuada entre contribuintes do imposto (pessoas que praticam atos de compra e venda de mercadorias). Caso a operação ocorra entre um

${ }^{701}$ Trecho da Ação Direta de Inconstitucionalidade n 4628. Disponível em: <www.stf.jus.br.> Acesso em 31 de outubro de 2012 
contribuinte (comerciante - remetente) e um consumidor final, o ICMS será devido somente ao Estado de origem das mercadorias ou bens.

A ADIN ajuizada pela Confederação Nacional do Comércio, assim como o pedido de medida cautelar, não havia sido apreciada pelo STF até o final de 2012. Em ADINs propostas para suspender leis estaduais dos Estados do Piauí e Paraíba, que exigiam o ICMS relativo às operações a ICMS no destino, a Suprema Corte concedeu liminares para suspender os efeitos dos atos normativos até a apreciação definitiva do mérito.

Uma Proposta de Emenda à Constituição relativa ao ICMS incidente nas vendas não presenciais, que praticamente reproduz o disposto no Protocolo ICMS $\mathrm{n}^{\circ}$ 21/2011, a PEC 103/2011, foi aprovada pelo plenário do Senado em 04.07.2011. A PEC modifica os critérios de distribuição do Imposto sobre Circulação de Mercadorias e Serviços incidente sobre o comércio de bens e serviços pela Internet; a proposta inicial acrescentava o inciso VII-A ao $\S 2^{\circ}$ do art. 155 da Constituição Federal, para modificar a sistemática de cobrança do imposto incidente sobre as operações e prestações realizadas de forma não presencial e que destinem bens e serviços a consumidor final localizado em outro Estado. ${ }^{702}$

Foram apresentadas várias emendas à proposta original e, em 03.07.2012, foi aprovado na Comissão de Constituição, Justiça e Cidadania - CCJ o Relatório do Senador Renan Calheiros, que acolhe parcialmente as Emendas apresentadas, com a seguinte redação:

Art. $1^{\circ}$ Os incisos VII e VIII do $\S 2^{\circ}$ do art. 155 da Constituição Federal passam a vigorar com a seguinte redação:

"Art. 155.

[...]

VII- nas operações e prestações que destinem bens e serviços a consumidor final, contribuinte ou não do imposto, localizado em outro Estado, aplicar-se-á a alíquota interestadual e caberá ao Estado de localização do destinatário o imposto correspondente à diferença entre:

a) a alíquota interna do Estado destinatário e a alíquota interestadual, quando o consumidor final for contribuinte do imposto;

b) a alíquota interna do Estado remetente e a alíquota interestadual, quando o consumidor final não for contribuinte do imposto.

VIII- a responsabilidade pelo recolhimento do imposto correspondente à diferença entre a alíquota interna e a interestadual de que trata o inciso VII será atribuída:

702 Cf. Parecer da Comissão de Constituição e Justiça de Cidadania, Disponível em: < http://www6.senado.gov.br/mate-pdf/98234.pdf>. Acesso em 2 de novembro de 2012. 
a) Ao destinatário, quando este for contribuinte do imposto;

b) Ao remetente, quando o destinatário não for contribuinte do imposto.

Relembremos a redação do Art. 155, II, parágrafo $2^{\circ}$ da CF em vigor, que disciplina a incidência do ICMS nas operações interestaduais:

VII - em relação às operações e prestações que destinem bens e serviços a consumidor final localizado em outro Estado, adotar-se-á:

a) a alíquota interestadual, quando o destinatário for contribuinte do imposto;

b) a alíquota interna, quando o destinatário não for contribuinte dele;

VIII - na hipótese da alínea "a" do inciso anterior, caberá ao Estado da localização do destinatário o imposto correspondente à diferença entre a alíquota interna e a interestadual.

Comparando-se a redação atual e aquela da PEC, nota-se que a proposta aprovada deixa de fazer a distinção que a Constituição Federal faz atualmente entre contribuintes e não contribuintes nas operações que destinem bens e serviços a consumidor final localizado em outro Estado: aos contribuintes, é aplicada a alíquota interna, enquanto aos não contribuintes aplica-se a alíquota interestadual (Art. 155, $\S 2^{\circ}$, inciso VII, alíneas "a" e "b").

Se for aprovada a PEC n 103/2011, a alíquota interestadual se aplicará a contribuintes e não contribuintes, pessoas físicas ou jurídicas, nas operações que destinem bens e serviços a consumidor final localizado em outro Estado.

Além disto, a proposta final da PEC deixa de diferenciar, para efeito de aplicação da alíquota interestadual, as operações feitas por meio eletrônico de quaisquer outras operações que remetam bens e serviços a consumidor final localizado em outro Estado, atribuindo a diferença entre a alíquota interestadual e a interna ao Estado de localização do destinatário.

Neste sentido, o inciso VII foi desdobrado para esclarecer que, para o cálculo da diferença entre a alíquota interna e interestadual, a utilização da alíquota interna do Estado destinatário ou do Estado remetente dependerá de o consumidor final ser contribuinte ou não do imposto: "quando o destinatário for contribuinte, a diferença será calculada entre a alíquota interna do Estado destinatário e a interestadual. Mas, no caso de 
não contribuinte, a diferença será entre a alíquota interna do Estado remetente e aquela interestadual". 703

Por fim, a PEC $n^{\circ} 103 / 2011$ introduz no texto constitucional, no inciso VIII do Art. 155, II, parágrafo $2^{\circ}$ da $\mathrm{CF}$, um regime de responsabilidade relativo ao recolhimento da diferença no imposto apurada na aplicação da alíquota interestadual e a interna.

A proposta foi encaminhada à Câmara dos Deputados em 09.07.2012 e, se aprovada, deverá ser promulgada. A justificativa do projeto considera que a atual regra constitucional de distribuição de receita do ICMS aplicável às operações interestaduais “foi desenhada há quase cinquenta anos". 704

A proposta de Emenda à Constituição demonstra que o Brasil está deslocando a incidência do ICMS interestadual da "origem" para o "destino", aonde se localiza o consumidor do produto ou serviço, privilegiando, neste sentido, a teoria da fonte de produção de rendimentos.

\subsection{Da Tributação do Consumo no Comércio Eletrônico}

Como destacamos no presente trabalho, o conceito de comércio eletrônico abarca duas modalidades de operações: o comércio eletrônico direto e o comércio eletrônico indireto. Se a transação não prescinde da entrega física do bem ou da prestação presencial do serviço, devendo os produtos ser expedidos ou transportados por serviços postais ou de outra natureza, ou ainda o serviço prestado de forma presencial, temse o comércio eletrônico indireto. Vale dizer, neste tipo de comércio, ocorre somente a aquisição dos bens e serviços por meio de canais informáticos.

Já no comércio eletrônico direto, todas as etapas, os procedimentos da transação, desenvolvem-se em ambiente eletrônico, abrangendo, além da contratação em si, também a execução do próprio contrato, por meio da entrega eletrônica do bem ou serviço.

Esta integração de meios telemáticos às transações do comércio eletrônico pode impactar dois critérios da regra-matriz de incidência dos impostos

\footnotetext{
703 Cf. Parecer da Comissão de Constituição e Justiça de Cidadania, Disponível em: <http://www6.senado.gov.br/mate-pdf/98234.pdf > . Acesso em 2 de novembro de 2012.

${ }^{704}$ Ibidem. Acesso em 2 de novembro de 2012.
} 
incidentes sobre o consumo, quais sejam: o critério espacial e o critério material. Em linhas gerais, nas operações indiretas, o aspecto espacial da norma tributária pode apresentar dois fenômenos distintos: coexistência de dois ou mais locais elegíveis para integrar o critério espacial da norma ou inexistência de qualquer local físico (estabelecimento virtual).

Por outro giro, as atividades relativas às transações se desenvolvem em dois ou mais locais distintos, ou a empresa realiza suas operações comerciais por meio de um web site (estabelecimento virtual), sem localização geográfica determinável, não se configurando qualquer lugar físico atrelado às operações; em ambas as situações, há dificuldade na definição do local exato em que se deve considerar executado o serviço ou comercializada a mercadoria.

Para que se possa definir com precisão qual o ente político competente para tributá-las, torna-se necessário, em função da multiplicidade ou "inexistência" de locais em que se desenvolvem as operações, ou da própria condição de seu desenvolvimento em "ambiente virtual", que haja um elemento de conexão definido e suficientemente caracterizado no ordenamento jurídico.

No tocante à materialidade, as transações eletrônicas diretas possibilitaram uma nova categoria de operações cuja qualificação provoca um abalo na definição do critério material destas operações, perturbando a subsunção dos fatos jurídicos subjacentes às normas de competência tributária. Desta forma, por exemplo, as novas tecnologias cloud computing estão sendo absorvidas no mercado nacional com a natureza jurídica a elas atribuída no exterior, ou seja, como serviços, sem que tenham sido desenvolvidos no campo tributário quaisquer estudos para determinar a essência do instituto com o intuito de classificá-lo dentro do universo de figuras existentes no Direito.

Partindo-se desses pressupostos propomos a seguinte estrutura de situações possíveis, ínsitas ao comércio eletrônico: 


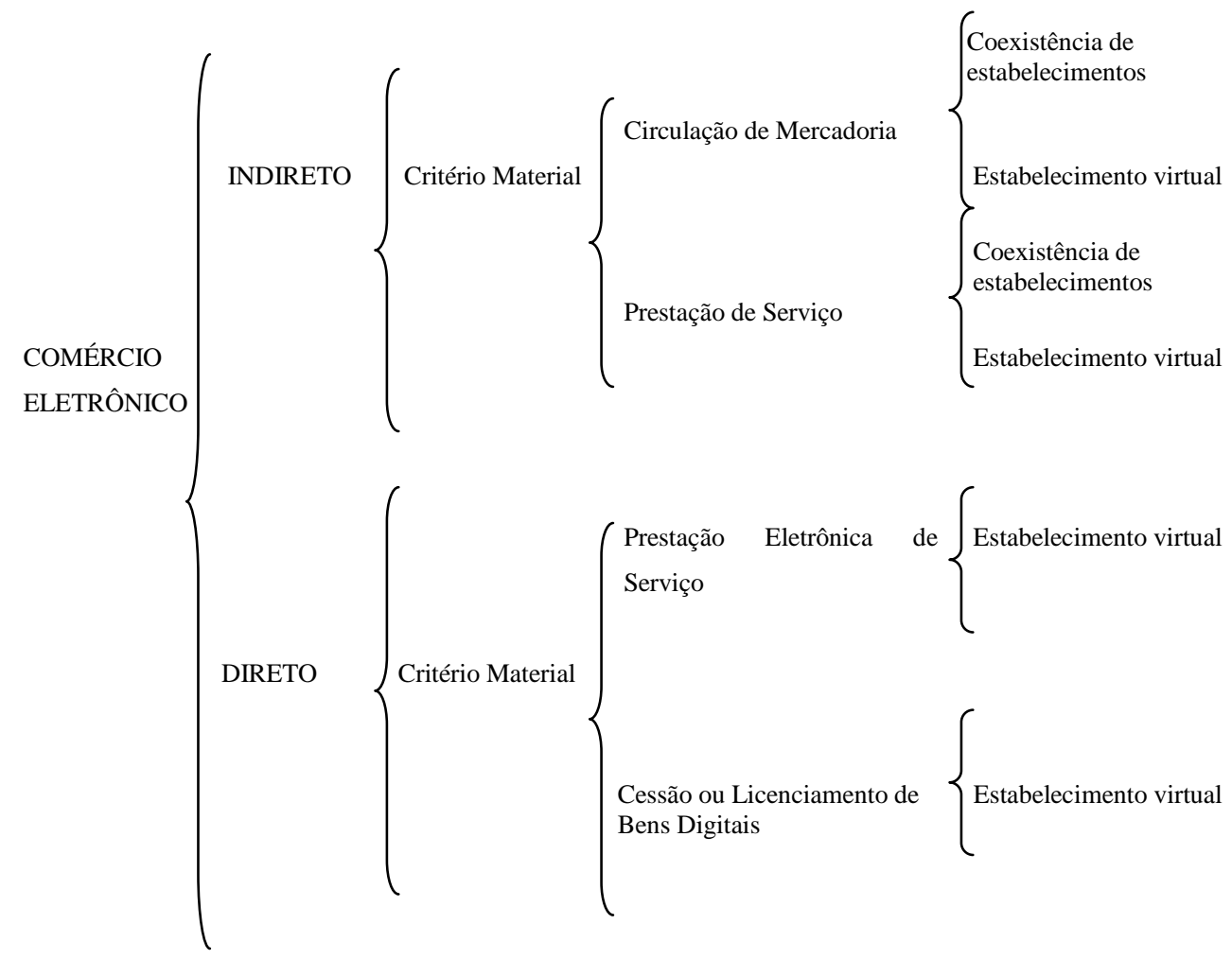

Tomando por base o esquema proposto, visualizamos diversas hipóteses a serem analisadas em relação ao comércio eletrônico, as quais passamos a investigar com base no aporte teórico desenvolvido previamente.

\subsection{O Comércio Eletrônico Indireto}

Conforme já debatido, o conceito de comércio eletrônico indireto designa o fornecimento de bens ou a prestação de serviços convencionais, representando os meios eletrônicos meros instrumentos de comunicação que facilitam a concretização das transações tradicionais, como a compra de eletrodomésticos, peças de vestuário e outros produtos via Internet ou a contratação de um profissional por meio de seu site na web para o desenvolvimento de um serviço de modo presencial. 


\subsubsection{Critério Material}

Tanto no fornecimento de bens como na prestação de serviços desempenhados no comércio eletrônico indireto, finalizada a transação por meios telemáticos, a conclusão das operações desenvolve-se de forma tradicional, com a entrega física da mercadoria ao comprador ou com a prestação do serviço de forma pessoal. Portanto, reproduzem-se os modelos jurídicos de comércio já existentes, com novas fórmulas resultantes da incorporação de tecnologia.

Desta forma, o fato jurídico subjacente às duas operações pode ser assim descrito: realizar operação mercantil, ou de prestação de serviços, contratada por meios eletrônicos, cujo produto (bem ou serviço), em função da própria natureza, não prescinde da entrega presencial.

Note-se que a utilização dos meios telemáticos em nada alterou a estrutura do fato jurídico relativo à aquisição ordinária de bens ou serviços, exceto sua viabilização por meio de "contratos eletrônicos". Estes instrumentos operacionalizam a manifestação de vontade dos contratantes (oferta e aceitação) que não se veicula oralmente nem por documento escrito, mas apenas pelo registro em meio virtual. $O$ contrato eletrônico, contrato-e, tem como suporte o registro eletrônico "em que as partes manifestam suas vontades convergentes através da transmissão e recepção eletrônica de dados". 705

Assim sendo, apesar dos reflexos econômicos advindos da nova sistemática, a repercussão tributária em termos materiais nos fatos jurídicos "realizar operação mercantil" e "prestar serviço" limitam-se à alteração na forma de contratação.

Portanto, podemos concluir que, no que tange à materialidade, há perfeita subsunção dos fatos jurídicos inerentes ao comércio eletrônico indireto aos critérios materiais das respectivas normas gerais e abstratas dos impostos incidentes sobre o consumo; tratando-se de operação mercantil, incidirá, nos termos do art. 155, II da Constituição Federal, o ICMS; caso descrevam uma prestação de serviços não abrangida no art. 155, II, incidirá nos termos do art. 156, III da Carta Magna, o Imposto sobre Serviços de Qualquer Natureza.

${ }^{705}$ Cf. COELHO, Fábio de Ulhoa, op. cit. (nota 91), p. 37. 


\subsubsection{Da "Circulação de Mercadorias"}

As operações mercantis realizadas por meio do comércio eletrônico indireto, apesar de estarem fora do escopo do presente trabalho, serão brevemente analisadas, por estarem intrinsecamente vinculadas ao conceito de "comércio eletrônico". Já concluímos que, no comércio eletrônico indireto, as operações mercantis serão tributadas pelo ICMS, ainda que toda a transação se desenvolva por meios telemáticos, já que a natureza do bem ou produto não prescinde de entrega física; ou seja, a relação jurídico-tributária, que nasce com a transmissão jurídica da propriedade da mercadoria, permanece inalterada.

A hipótese do Imposto sobre Circulação de Mercadorias descreve o fato de um comerciante, industrial ou produtor praticar a operação jurídica de transferir, física ou simbolicamente, a propriedade da mercadoria. Ocorridos estes eventos no mundo fenomênico, subsumem-se ao fato hipoteticamente descrito na regra-matriz, fazendo nascer a relação jurídica entre o sujeito passivo que realizou a operação mercantil e o sujeito ativo do Estado de onde a mercadoria será transferida. ${ }^{706}$

Desta forma, como já afirmamos, ocorre uma perfeita subsunção dos fatos jurídicos ocorridos sob este regime ao critério material daquelas normas gerais e abstratas instituidoras do imposto sobre circulação de mercadorias, em nada interferindo na relação jurídica estabelecida no consequente.

Abordamos no item 6.2 do presente trabalho o desequilíbrio na arrecadação do ICMS provocado pelo comércio eletrônico, que levou alguns Estados à celebração do Protocolo ICMS n 21 , por força do qual, nas operações desenvolvidas de modo eletrônico e que envolva dois Estados diversos, prevalecerá a alíquota interestadual, ainda que o consumidor não seja contribuinte do imposto, situação que deverá se estabilizar com a aprovação de uma Emenda Constitucional relativa ao assunto.

${ }^{706}$ Cf. CARVALHO, Paulo de Barros, op. cit. (nota 19), p. 650. 


\subsubsection{Da Prestação de Serviços}

A materialidade dos serviços prestados na sistemática do comércio eletrônico indireto, a exemplo do que ocorre na circulação de mercadorias, não apresenta qualquer alteração em relação àquelas operações tradicionais. Vários serviços podem hoje ser divulgados e contratados por vias eletrônicas, mas sua execução desenvolve-se de forma presencial.

Assim sendo, projetos de arquitetura, design de interiores, entre outros, ainda que avençados e desenvolvidos por e-mail ou conferências eletrônicas, não prescindem de uma intervenção presencial, por exemplo, com vistorias e medições que implicam em contato físico entre o prestador e o cliente.

Destarte, o fato jurídico subjacente à operação de prestar serviço no comércio eletrônico indireto pode ser assim descrito: desenvolver atividade de prestar serviço, contratada por meios eletrônicos, cuja execução, em função da própria natureza do serviço, não prescinde da prestação presencial.

Portanto, concluímos que não há qualquer intercorrência na subsunção dos fatos jurídicos de prestar serviço no regime do comércio eletrônico indireto à norma geral e abstrata do Imposto sobre Serviços, já debatida neste estudo.

\subsubsection{Critério Espacial do Imposto sobre Serviços}

A problemática a ser enfrenta em relação às operações realizadas por meio do comércio eletrônico indireto refere-se à definição do local onde ocorre a incidência do Imposto sobre Serviços de Qualquer Natureza e do Imposto sobre a Circulação de Mercadorias, ou seja, a definição do critério espacial da regra-matriz de incidência dos referidos impostos.

Já definimos que, nas operações indiretas, o aspecto espacial da norma tributária pode apresentar duas situações distintas: coexistência de dois ou mais locais elegíveis para integrar o critério espacial da norma ou inexistência de qualquer local físico (estabelecimento virtual). 
Em função do escopo de nosso trabalho, iremos nos deter com mais profundidade nas questões relativas ao ISS, prestando-se as conclusões alcançadas, de forma genérica, ao ICMS.

\subsubsection{Coexistência de Locais}

Conforme já abordamos, as operações do comércio eletrônico indireto, ainda que se desenvolvam em grande parte por meios virtuais, exigem por força de legislação ou revelam pela própria natureza da operação uma base física a elas relacionada, que poderia ser interpretada como o elemento de conexão cabível no critério espacial da regra-matriz de tributação dos fatos jurídicos.

No entanto, na definição do elemento de conexão que indicará a jurisdição competente para tributar determinados serviços prestados por meios eletrônicos, podemos nos deparar com a existência de mais de um elemento de conexão possível. Eleger entre estes, aquele adequado à atribuição da competência tributária a determinado ente, considerando-se os meios tecnológicos envolvidos, dependerá dos critérios adotados para cada situação.

Relativamente ao critério espacial do ISS, a Lei Complementar $\mathrm{n}^{\circ}$ 116/2003 dispõe a regra geral - estabelecimento prestador, relacionando ainda vinte espécies de serviços que constituem exceções àquela regra, quando o imposto será devido, de modo geral, no local da prestação do serviço.

A definição de "estabelecimento prestador" ou do local onde foi prestado o serviço possui características próprias, sejam elas provenientes de normas legais ou detectáveis em função de critérios desenvolvidos pela doutrina. Desta forma, para que se configure o estabelecimento prestador, em cumprimento ao conceito legal da lei complementar, exige-se a concomitância do elemento subjetivo e dos elementos objetivos, conforme discutimos no item 5.12.3 deste estudo.

O conceito de estabelecimento prestador adotado pelo STJ prescinde de alguns elementos objetivos exigidos pela Lei Complementar $n^{\circ} 116 / 03$, como a base física e a estrutura organizacional, concentrando a configuração no elemento subjetivo, considerando que a alocação de pessoal especializado no estabelecimento do tomador, ainda que temporária, é suficiente para a configuração do "estabelecimento prestador", 
aproximando-se neste diapasão daquele conceito de "estabelecimento permanente" adotado pelas convenções internacionais com base no Modelo da OCDE.

Do estudo sistemático dos tratados internacionais, da doutrina e do ordenamento jurídico nacional, extraímos os seguintes elementos de conexão possíveis para atribuição de competência tributária sobre os serviços prestados por meio da Internet:

a. Local do estabelecimento prestador: teoria da residência e da origem;

b. Local da constituição da obrigação, assim considerado aquele onde estiver estabelecido o proponente do contrato telemático: teoria da fonte de produção dos rendimentos e do destino;

c. Local onde se desenvolvem as atividades: teoria da atividade;

d. Local onde foram produzidas as utilidades (os resultados) dos serviços: teoria da utilidade.

O elemento de conexão "local do estabelecimento prestador" pode ser enfocado como a aplicação da teoria da residência (e da origem) ou da teoria da atividade. Nos casos em que o serviço desenvolve-se de fato no estabelecimento da empresa, tem-se a teoria da atividade, já que ali se desenvolveu a atividade de prestar os serviços. Já nos casos em que o estabelecimento prestador corresponde a uma ficção jurídica, por exemplo, quando os serviços são prestados de forma simultânea em diversos lugares, entrevemos a teoria da residência, em que o tributo é devido na sede da empresa que presta os serviços.

Constatamos neste estudo que o conceito de "estabelecimento permanente" no direito internacional tem como pressuposto configurador a coexistência das seguintes condições: (i) instalação material, ou seja, um estabelecimento físico; (ii) caráter de permanência, representado em um elemento temporal e espacial; (iii) as atividades da empresa devem se desenvolver nas mencionadas instalações e (iv) as atividades desenvolvidas nesta instalação devem coincidir com aquelas praticadas pela empresa a que se atribui um "estabelecimento permanente".

No direito pátrio, conforme já debatemos, a configuração de um estabelecimento como "prestador de serviços" exige a presença concomitante de um elemento objetivo e um elemento subjetivo. O elemento objetivo, representado pela "unidade econômica ou profissional", considera o complexo de bens da empresa necessários e inerentes ao exercício da atividade empresarial ou profissional. Engloba, assim, a estrutura física e organizacional que representa o local para a prestação em si, o 
pessoal técnico, a existência de maquinário ou equipamentos necessários ao serviço especificamente prestado, entre outros.

O elemento subjetivo da definição é o animus de permanência em determinado local para a prestação de serviços, evidenciado por circunstâncias externas que revelem esta intenção do sujeito.

Cotejando os pressupostos configuradores do conceito de "estabelecimento permanente" definidos no direito internacional com os elementos objetivo e subjetivo do conceito pátrio de "estabelecimento prestador", vislumbramos entre eles uma conformidade. Nosso elemento objetivo corresponde no direito internacional ao pressuposto da instalação material, ou seja, do estabelecimento físico. A estrutura organizacional inerente ao conceito nacional pode ser visualizada na exigência internacional de que as atividades da empresa se desenvolvam nas mencionadas instalações.

O elemento subjetivo enquanto animus de permanência, por seu turno, seria correlato ao elemento temporal internacional associado à exigência de que as atividades da empresa se desenvolvam nas mencionadas instalações. As normas brasileiras não definem, como a internacional, um critério temporal objetivo, como um período determinado de tempo, necessário e suficiente à configuração da permanência de uma atividade em determinado local.

Ao invés disto, a configuração desta intenção no direito pátrio é captada por meio de elementos como a inscrição do endereço em órgãos previdenciários, sua indicação como domicílio fiscal para outros tributos, a menção do estabelecimento em cartões, sites da Internet, publicidade, contas de energia elétrica, telefones e outros que denotam a fixação naquele determinado lugar.

Ressalte-se que, no entanto, o Superior Tribunal de Justiça, no julgamento do REsp $n^{\circ} 1.195 .844^{707}$, considerou na configuração de um estabelecimento prestador um elemento temporal, entendendo que a disponibilização de pessoal técnico atuando no estabelecimento do prestador por certo período de tempo (seis meses) caracterizou uma "unidade econômica ou profissional", suficiente a legitimar o ente estatal aonde foram prestados os serviços para a cobrança do ISS.

${ }^{707}$ O REsp $n^{\circ} 1.195 .844$ foi analisado no item 5.17 deste estudo. 
Por fim, a exigência internacional de que as atividades praticadas pela empresa a que se atribui um "estabelecimento permanente" devem coincidir com aquelas que serão desenvolvidas pelo novo estabelecimento não encontra similar no direito pátrio.

Conforme já debatido, a utilização do elemento de conexão que privilegia o local do estabelecimento prestador corresponde, geralmente, ao local da residência na atribuição da competência impositiva, o que pode ensejar distorções na arrecadação dos tributos no comércio eletrônico.

Neste sentido, remetemos à leitura do item 6.2, que analisa o desequilíbrio na arrecadação do ICMS entre os Estados brasileiros, provocado pelo sistema da origem (residência) no comércio eletrônico, que culminou com a celebração do Protocolo ICMS n ${ }^{\circ} 21$. Além disto, toda a discussão no Direito Tributário Internacional tem como problemática justamente a tendência da concentração da tributação na residência em detrimento da fonte que seria enfraquecida pela ausência de presença física que constitua um "estabelecimento permanente".

Desta forma, entendemos que este não seria o elemento de conexão mais adequado para a definição da competência tributária sobre os serviços prestados por meios telemáticos, na medida em que pode gerar desequilíbrio na arrecadação dos tributos, favorecendo os Municípios mais desenvolvidos, que concentram as atividades empresariais mais relevantes. Impende ressaltar que esta é a regra geral vigente, na dicção da Lei Complementar $\mathrm{n}^{\circ} 116 / 03$, de forma que, enquanto não houver qualquer alteração legislativa, é a que deve prevalecer.

Nosso sistema jurídico também adota a teoria da atividade, representada na incidência do ISS no local onde o serviço for executado, que corresponde àqueles casos cuja prestação de serviço, por suas peculiaridades fáticas, desenvolve-se notoriamente fora do estabelecimento prestador, enumerados nos incisos I a XXII do artigo $3^{\circ}$ da $\mathrm{LC} \mathrm{n}^{\circ}$ 116/2003. Da mesma forma, também na regra do "estabelecimento prestador" e, na ausência deste no domicílio do prestador, entreve-se a teoria da atividade quando ali se desenvolve, de fato, o esforço humano relativo à prestação de serviço.

A teoria da fonte de produção dos rendimentos, por sua vez, exprime-se também na teoria da utilidade e na teoria da constituição da obrigação, representadas pelo local onde está situado o consumidor dos bens ou serviços, que coincide com o local onde é disponibilizada a utilidade e onde é constituída a obrigação, conforme abordamos no capítulo 3. 
A teoria da fonte dos rendimentos, que considera o local onde os serviços produzem seus resultados e onde estão situados os tomadores dos serviços para a definição da competência impositiva, parece ser a mais adequada às transações do comércio eletrônico, em especial na modalidade direta. A proposta alcançaria de maneira mais tranquila um entendimento predominante no cenário internacional, contando ainda com a prevalência da doutrina que se debruça sobre o tema.

O problema em relação à adoção do critério da fonte é como dar-lhe efetividade; numa primeira aproximação, parece-nos que a adoção da fonte como elemento de conexão para definição da competência tributária caminha no sentido inverso àquele adotado pelos Fiscos nacionais, que têm preferido a instituição de responsabilidade tributária como mecanismo para concentrar os atos de fiscalização de inúmeros fatos tributários em uns poucos fatos jurídicos.

A proposta de Drigo da Silva para atribuir efetividade à tributação na fonte dos rendimentos, assim considerado o local onde se encontra o tomador do serviço, é justamente a adoção de um sistema de responsabilidade tributária. ${ }^{708}$ No mesmo sentido caminha a proposta de Emenda Constitucional relativa ao ICMS incidente no comércio eletrônico, a que nos referimos no item 6.2, que atribui a responsabilidade pelo recolhimento da "diferença de alíquota" nas operações interestaduais ao destinatário da mercadoria, quando este for contribuinte do imposto, e a seu remetente quando tratar-se o destinatário de consumidor final não contribuinte do imposto.

A responsabilidade sugerida por Drigo, relativa às operações do comércio eletrônico, seria atribuída aos intermediários envolvidos na remuneração das respectivas operações. Os pagamentos feitos pelos tomadores de serviço são realizados por meio de ordens de pagamento, transferências eletrônicas (TED), boletos bancários emitidos por instituições financeiras, cartões de crédito ou, mais modernamente, pelos sistemas de pagamento digital voltados especificamente para o comércio eletrônico.

Trata-se de um novo serviço financeiro direcionado a compradores e vendedores pela Internet, surgida em 2007 no Brasil, que garante a segurança dos pagamentos nas operações eletrônicas na $w e b$, pela retenção do valor pago pelo adquirente de um bem ou serviço até o recebimento do produto ou serviço, além de oferecer ao cliente várias opções de pagamento e, até mesmo, o parcelamento. Nesta nova sistemática, pode o

${ }^{708}$ Cf. SILVA, Emerson Drigo da, op. cit. (nota 102), p. 125. 
adquirente optar pelo pagamento em qualquer uma das opções de pagamento mencionadas (boleto, cartão, TED), com a vantagem de garantir que serviço será prestado ou o produto entregue, sendo o pagamento repassado ao fornecedor somente após sua execução.

Greco já havia alertado para o fato de que um dos poucos elementos captáveis neste universo de comércio de bens virtuais e transações eletrônicas seria a movimentação financeira decorrente das operações ali desenvolvidas. ${ }^{709}$ Portanto, seriam responsáveis pelo recolhimento do valor do imposto relativo às prestações de serviço por meios eletrônicos as instituições financeiras, as administradoras de cartão de crédito ou as empresas que administram operações de pagamento digital. ${ }^{710}$

A identificação entre os diversos pagamentos realizados por meio das instituições financeiras e administradoras de cartão de crédito daqueles provenientes do comércio eletrônico poderia ser feita por meio do registro prévio das empresas que atuam no ramo, o que seria desnecessário para as empresas de pagamento digital que se dedicam exclusivamente às transações via web.

A responsabilidade tributária atribuída às administradoras de cartão foi analisada por Vitor Bellan, alertando o autor que estas empresas não preenchem o vínculo exigido pelo artigo 128 do CTN, vez que possuem uma relação comercial com seus filiados. De fato, há limites legais para a definição do responsável tributário, exigindo-se, além de expressa previsão legal, a vinculação do responsável ao fato jurídico-tributário correspondente. A conclusão do autor é que a lei tributária não pode eleger as administradoras de cartão de crédito como responsáveis pelo ISS ou ICMS devidos por seus filiados em razão de transações eletrônicas. ${ }^{711}$ Ressalte-se que tal restrição não ocorreria com as empresas de pagamento digital, que são intermediárias nos negócios digitais.

Relativamente ao ISS, o art. $6^{\circ}$ da Lei Complementar $n^{\circ} 116 / 2003$ autoriza os Municípios e o Distrito Federal a, mediante lei, atribuir a responsabilidade pelo

\footnotetext{
${ }^{709}$ Cf. GRECO, Marco Aurélio, op. cit. (nota 86), p. 192.

${ }^{710}$ Cf. SILVA, Emerson Drigo da, op. cit. (nota 102), p. 125.

${ }^{711}$ Cf. BELLAN, Daniel Vitor, Comércio Eletrônico e Responsabilidade Tributária das Administradoras de Cartão de Crédito, In Internet - O Direito na Era Virtual, SCHOUERI, Luis Eduardo, organizador, $2^{\mathrm{a}}$. ed. Rio de Janeiro, Forense, 2001, p. 209.
} 
crédito tributário a terceira pessoa vinculada ao fato gerador da obrigação, excluindo-se a responsabilidade do contribuinte ou atribuindo-lhe a responsabilidade subsidiária. ${ }^{712}$

E muitas são as hipóteses de responsabilidade atribuídas hoje às instituições bancárias e administradoras de cartão relativas ao ISS. No entanto, as sistemáticas instituídas colhem os responsáveis enquanto tomadores dos serviços de limpeza, vigilância, coleta de correspondência, entre outros autorizados pela norma geral.

Portanto, a adoção de medidas no sentido de atribuir a responsabilidade às instituições financeiras não prescindiria de reformas na legislação complementar vigente, viabilizando sua aplicação prática.

Uma maneira de dar efetividade à tributação na fonte dos rendimentos seria a instituição de um dever instrumental às empresas envolvidas na remuneração das operações do comércio eletrônico, que consistiria em uma declaração mensal dos valores repassados a fornecedores de bens e serviços pré-cadastrados, envolvidos em transações eletrônicas.

O regime especial relativo ao comércio eletrônico, adotado pela Comunidade Europeia em 2007, deve também ser considerado como solução para a problemática do critério espacial da norma de incidência. Vimos que, pela sistemática criada, os prestadores de serviços eletrônicos não residentes devem se cadastrar previamente perante o Estado no qual pretendem desenvolver seus trabalhos, permitindo que se exerça um rígido controle sobre estas operações, quando prestadas a residentes por empresas estabelecidas fora da Comunidade. ${ }^{713}$

Impende ressaltar que a adoção de uma medida similar pressupõe a reunião de um grupo de Estados interoperando ou a existência de um bloco econômico formal, a exemplo da Comunidade Europeia, ou de um tratado específico. Neste sentido, o grupo do MERCOSUL Digital poderia auxiliar na viabilização da medida no âmbito dos países membros na América do Sul.

\footnotetext{
${ }^{712}$ Cf. HOFFMANN, Suzy Gomes, A Competência dos Municípios para a Instituição e Cobrança do ISSQN e a Responsabilidade Tributária do Tomador de Serviços no Pagamento do ISSQN, Revista Dialética de Direito Tributário, São Paulo, Dialética, no. 105, pp. 89-90.

${ }^{713} \mathrm{O}$ tema do regime especial adotado pela CE foi abordado no item 3.1 do presente trabalho.
} 


\subsubsection{O Servidor de Dados}

Outra situação recorrente a ser investigada, relativa às operações no comércio eletrônico indireto, é a definição do critério espacial naquelas situações em que há o desdobramento das atividades da empresa, com a incorporação de um servidor de dados executando parte das funções. A cisão dos serviços em dois ou mais segmentos tem sido fulcro de conflitos de competência entre entes políticos, impondo-se a fixação de critérios legais para a definiç̧ão de regras relativas à configuração, ou não, do servidor de dados como estabelecimento prestador.

$\mathrm{Na}$ ausência de normas concernentes ao tema em nosso ordenamento jurídico, iremos nos valer dos critérios fixados nos comentários da CM-OCDE relativos à configuração de um "estabelecimento permanente" por servidores de dados.

Vimos que a equiparação de servidores de dados ao conceito de "estabelecimento permanente", estabelecendo o nexo para a repercussão tributária, tem sido objeto de preocupação dos organismos internacionais. Dos esforços despendidos sobre as referidas normas, vislumbramos que de fato um servidor de dados pode, no cenário internacional, configurar um "estabelecimento permanente".

Nos termos dos comentários à Convenção Modelo da OCDE, para que haja a percussão tributária relativamente aos servidores de dados utilizados pelas empresas, devem estar presentes concomitantemente os seguintes requisitos: (i) estar afixados em determinado território por um período de tempo suficiente; (ii) as atividades da empresa sejam total ou prioritariamente desenvolvidas no equipamento; (iii) que as atividades desenvolvidas no servidor não se configurem como preparatórias ou auxiliares, sendo dispensável a presença de representantes ou agentes da empresa operando o equipamento.

Alguns entreveem no equipamento um mero facilitador de operações, de modo que não poderia ser considerado como um negócio em si, mas apenas uma conduta de negócios, posto que não constituiria um centro autossuficiente da atividade econômica. No caso em que as funções de uma empresa são repartidas, atribuindo-se parte delas a um servidor, o equipamento não desempenharia mais do que mero papel passivo. ${ }^{714}$

${ }^{714}$ Cf. PINTO, Dale, op. cit. (nota 288), p. 48. 
No entanto, se considerarmos que o servidor constitui um equipamento tangível, conforme as diretrizes da OCDE, ele configuraria um local de negócios, desde que presentes os outros requisitos inerentes ao conceito. Uma das condições necessárias para que um equipamento de informática constitua um "estabelecimento permanente" é que ele esteja afixado em determinado lugar por um período de tempo suficiente para corresponder ao conceito de "fixo".

Outro fator relevante a ser verificado é se o negócio da empresa se desenvolve total ou parcialmente no local onde se localizam os equipamentos, como o servidor de dados; segundo o comentário 42.5, a análise deve ser casuística, verificando-se se as atividades da empresa são desempenhadas por meio destes equipamentos.

Além disto, em relação às atividades desenvolvidas pelos equipamentos, devem ainda ser considerados os conceitos de "atividades preparatórias ou auxiliares", abrangidas pelo parágrafo $4^{\circ}$ do artigo $5^{\circ}$ da $\mathrm{CM}-\mathrm{OCDE}$, que não têm o condão de percutir tributariamente. A análise, necessariamente casuística, deve considerar as diversas funções desempenhadas por uma empresa por meio desses equipamentos, distinguindo aquelas que constituem, em si mesmas, parte essencial e significativa do objeto social de uma empresa, daquelas que encerram o caráter de meras atividades preparatórias.

\subsubsection{Inexistência de Estabelecimento Físico - Web Site}

Em algumas operações do comércio eletrônico, relativamente ao critério espacial, revela-se o fenômeno do "estabelecimento virtual", não se configurando, normalmente, qualquer lugar físico suficiente a possibilitar a percussão tributária.

Já investigamos o instituto jurídico do estabelecimento virtual e suas características no item 5.15. Vimos ainda que, no direito internacional, um web site, uma mera combinação de software e dados eletrônicos, não pode, por si só, configurar um estabelecimento permanente.

Em relação aos sites na Internet, de modo geral, as normas internacionais não consideram que estes constituam um local de trabalho ou uma instalação. Os sites, que não são bens corpóreos, mas mera combinação de software e dados eletrônicos, não poderiam configurar um "estabelecimento permanente". Note-se que o equipamento automatizado no qual o site fica armazenado e por meio do qual é acessado possui uma localização física, podendo constituir um "lugar fixo de negócios" da empresa que opera o 
servidor. Desta forma, restaria configurado pelo servidor, enquanto equipamento, o estabelecimento da empresa responsável por sua operação.

Portanto, se uma empresa exercer suas atividades por meio de um web site e detiver um servidor de dados à sua disposição, adquirido ou arrendado, operando o equipamento no qual o site está armazenado, e utilizando o local onde o servidor está instalado, estaria configurado um "estabelecimento permanente", desde que presentes os outros requisitos contidos no artigo $5^{\circ}$ da Convenção Modelo.

Relativamente ao ICMS, ainda que a empresa atue no mercado somente através de um web site, no comércio eletrônico indireto o produto negociado é tangível, de forma que obrigatoriamente haverá um local físico de onde esta mercadoria será expedida, configurando-se no local onde ocorre a saída da mercadoria o critério espacial da regramatriz do imposto.

A proposta da doutrina nacional, elaborada por Greco, poderia servir de parâmetro à regulamentação do assunto. O critério classifica os sites em função das operações neles desempenhadas para analisar a hipótese de constituírem, ou não, um estabelecimento prestador; neste sentido, os sites meramente passivos, cujas atividades viabilizam somente a divulgação e a oferta dos serviços, fazendo as vezes de uma vitrine onde o produto é exibido, assim como os sites canalizadores de mensagens, que atuam normalmente vinculados a um estabelecimento físico que lhes dá suporte material nos pedidos recebidos por vias eletrônicas, devem ser considerados como meras extensões dos estabelecimentos.

Já os sites inteligentes, que além de receber pedidos, realizam operações mais complexas, interagindo com o usuário, confirmando disponibilidade de produtos, emitindo ordens de compra ou serviço, informando prazo de entrega, recebendo pagamento mediante cartão de crédito, pagamento digital ou emitindo boletos bancários, pela complexidade de atividades desenvolvidas no ambiente virtual, que em tudo se assemelham àquelas realizadas no mundo físico em uma loja ou estabelecimento tradicional, podem ser considerados como "estabelecimentos comerciais".

Considerando a obrigatoriedade de vinculação de um CNPJ da empresa e de um endereço fixo para o registro de nome de domínio, prevista na Resolução CGI.br/res/2008/008/P, entendemos que os critérios legais vigentes poderiam ser mantidos, propondo que se vinculasse o "estabelecimento virtual” àquele estabelecimento físico do 
titular do domínio sob o qual se encontra registrado o site ou e-mail, configurando-se este como o elemento de conexão adequado para constar do critério espacial da norma.

\subsection{O Comércio Eletrônico Direto}

Conforme já assentamos neste trabalho, o comércio eletrônico abrange tanto transações tradicionais operacionalizadas por instrumentos eletrônicos de comunicação quanto as operações viabilizadas totalmente por meios eletrônicos, inclusive a execução dos serviços ou a própria cessão dos bens, direitos autorais ou softwares.

Desta forma, no comércio eletrônico direto, o negócio é realizado de modo inteiramente virtual, sendo que todos os procedimentos da transação desenvolvem-se em ambiente eletrônico, abrangendo, inclusive, a conclusão do negócio e a execução do contrato, com a entrega eletrônica do bem ou a execução do serviço.

\subsubsection{Critério Material}

No comércio eletrônico direto, todas as etapas da transação desenvolvem-se em ambiente eletrônico, abrangendo, além da contratação em si, também a execução do próprio contrato, mediante a entrega eletrônica do bem ou serviço, como na aquisição de programas de computador ou conteúdos de diversão.

Neste modelo de transação integralmente digital, distinguimos dois tipos de operações: (i) a prestação de serviços ordinária, viabilizada totalmente por meios digitais, denominada "prestação de serviços eletrônica" e (ii) a cessão ou licenciamento dos "bens digitais". Neste compasso, passaremos a investigar o critério material de cada uma das modalidades de operações, verificando a equivalência entre as características do fato ocorrido e os predicados definidos nas normas gerais e abstratas dos impostos sobre o consumo.

\subsubsection{1. "Prestação Eletrônica de Serviços"}

$\mathrm{Na}$ "prestação eletrônica de serviços" as atividades anteriormente executadas por meios presenciais passaram a ser viabilizadas por meios telemáticos, 
dispensando qualquer contato direto entre as partes, podendo resultar da execução do serviço um produto eletrônico que é disponibilizado ao destinatário por vias telemáticas, transmitido por uma rede de dados. Ressalte-se que, em ambos os casos, a atividade de prestar o serviço em si resta preservada, atuando os meios digitais como facilitadores da atividade ou da tradição do resultado.

Desta forma, hoje se contrata e recebe, por meios exclusivamente eletrônicos, serviços como consultas jurídicas, projetos de engenharia, tradução de textos, psicoterapia, entre outros, nas quais o emprego dos meios telemáticos não desnatura a atividade de prestação do serviço propriamente dita. Ainda que, por exemplo, um serviço de tradução seja avençado e executado por correio eletrônico e a entrega do produto também possa consistir em um arquivo digital, pode-se visualizar a atividade de prestar o serviço de tradução, que se utiliza de computadores para a contratação, execução e entrega do serviço, mas não tem sua natureza jurídica alterada.

Portanto, em função de características intrínsecas dos próprios serviços, os meios telemáticos funcionam como facilitadores, possibilitando a execução do serviço sem qualquer contato presencial e evitando o deslocamento dos contratantes. A comunicação entre as partes efetuada por correio eletrônico ou conferências eletrônicas não constitui um contato físico, de forma que não altera a natureza jurídica destas operações, considerando-se que a prestação do serviço em si ocorre de modo não presencial. Por outro lado, ressalte-se que a mera comunicação por correio eletrônico entre o prestador e o tomador de um serviço não significa por si só que o serviço prestado seja um serviço eletrônico. ${ }^{715}$

Assim sendo, o critério material da regra-matriz do imposto sobre serviços permanece inalterado, podendo o fato jurídico ser descrito da seguinte forma: prestar serviço de qualquer natureza, de forma não presencial, utilizando-se de meios telemáticos no desenvolvimento do trabalho e efetuando a tradição do produto final, se for o caso, em formato de arquivo digital, por meio de uma rede eletrônica de dados.

Portanto, a exemplo do que ocorre no comércio eletrônico indireto, podemos concluir que não há qualquer variação ou irregularidade na subsunção dos fatos jurídicos subjacentes à "prestação de serviços eletrônica" à norma geral e abstrata do Imposto sobre Serviços, debatida neste estudo.

\footnotetext{
${ }^{715}$ Neste sentido, o art. 57, item 2, da Diretiva 2006/112/CE da Comunidade Europeia.
} 


\subsubsection{Fornecimento de Bens Digitais}

Além da prestação de serviços eletrônica, por meio do comércio eletrônico direto também se adquire em formato digital livros, músicas, fotos, jogos online, softwares se utiliza de bancos de dados, casos em que ocorre por parte do fornecedor a cessão dos bens digitais ou a licença de uso de softwares, entre outros produtos eletrônicos disponibilizados.

Nesta categoria do comércio eletrônico, temos o fornecimento ou o uso de "bens digitais" de forma on-line, sem qualquer intervenção humana, por meio de sites. Surge, portanto, neste contexto, a primeira questão jurídica relativa à natureza dos objetos virtuais adquiridos por meios telemáticos; vale dizer, impõe-se perquirir se os produtos eletrônicos adquiridos, que equivalem funcionalmente e são similares aos físicos, preservam a mesma natureza jurídica.

No sentir de Emerenciano, bens digitais não se tratam das mesmas coisas existentes no mundo físico, tanto no aspecto físico quanto ao seu funcionamento e às potencialidades de utilização, "mas de um equivalente funcional, de algo que realiza a mesma função que seu paralelo em forma física". ${ }^{716}$ A inexistência física alteraria a relação do objeto com o homem, condicionando sua utilização e funcionamento.

Tais conclusões podem ser explicadas em função da época em que foram alcançadas; no início da década passada, os objetos virtuais eram, em sua maioria, meras digitalizações de seus correspondentes físicos. Mas as alterações no mundo tecnológico são velozes e, apenas uma década depois, podemos ter outra percepção do fenômeno.

A distinção do original e da cópia perdeu pertinência há muito, já que o ciberespaço misturou as noções de unidade, identidade e localização. ${ }^{717}$ Quando se fotografa algo ou alguém, significa que se está obtendo uma imagem que os reproduza, independentemente do suporte em que será contida. Assim, o livro, a música e tantos outros objetos que hodiernamente compõem nosso cotidiano em forma digital, já nascem na condição de virtuais, podendo ser visualizados e acessados em várias mídias distintas, de modo que não há qualquer diferença entre um objeto digital e seu correspondente físico.

\footnotetext{
${ }^{716}$ EMERENCIANO, Adelmo da Silva, op. cit. (nota 39), p. 32.

${ }^{717}$ Cf. LEVY, Pierre, op. cit. (nota 48), p. 48.
} 
Pierre Lévy alerta que a oposição entre real e virtual é fácil e enganosa. "No uso corrente, a palavra virtual é empregada com frequência para significar a pura e simples ausência de existência, a 'realidade' supondo uma efetuação material, uma presença tangível”. E prossegue: “a virtualização não é uma desrealização, mas uma mutação de identidade, um deslocamento do centro de gravidade ontológico do objeto considerado". 718

A realidade do comércio eletrônico direto é povoada de bens digitais, conforme explanamos no item 2.4 deste trabalho. As transações que envolvem softwares representam atualmente uma das principais fontes de renda do comércio eletrônico e, portanto, uma análise sobre sua tributação pode trazer subsídios valiosos sobre a forma como as transações com outros produtos digitais podem ser caracterizadas.

A doutrina alienígena tem reconhecido que o fornecimento de bens digitais deve ser considerado uma prestação de serviços; no mesmo caminho dispõem normas do Direito Positivo relativas ao IVA na Comunidade Europeia e a legislação interna de diversos países como Itália, Espanha, França, dentre outras, que reconhecem as cessões de uso de direitos da propriedade intelectual como serviços. ${ }^{719}$

Os estudos internacionais relativos à tributação do software têm seu foco na qualificação da receita relativa às operações; na maioria dos países industrializados, os direitos em relação ao software são tutelados pelas leis de direitos autorais e sua receita deve ser qualificada de forma similar aos pagamentos relacionados às obras literárias, artísticas ou científicas, geralmente caracterizados como royalties. ${ }^{720}$

Neste sentido, a discussão referente à qualificação da renda proveniente da transferência de programas de computador como lucros da empresa ou royalties tem sido extensivamente tratada na literatura alienígena. $\mathrm{O}$ assunto é relevante em função da reserva do direito de reter na fonte dos pagamentos parte das receitas relativas aos royalties, feito por muitos países.

No Modelo da OCDE, o conceito de royalty contido no artigo 12 contempla as remunerações de qualquer natureza devidas pelo uso ou pela concessão do direito de uso de (i) direitos autorais sobre obras literárias, artísticas ou científicas, incluindo os filmes cinematográficos; (ii) patentes, marcas de indústria ou de comércio,

\footnotetext{
${ }^{718}$ LEVY, Pierre, op. cit. (nota 48), p. 16.

${ }^{719}$ Cf. EMERENCIANO, Adelmo da Silva, op. cit. (nota 39), pp. 164-165.

${ }^{720}$ Cf. PINTO, Dale, op. cit. (nota 288), p. 85.
} 
desenhos ou modelos, planos, fórmulas ou processos secretos; e (iii) informações relativas à experiência adquirida no setor industrial, comercial ou científico. ${ }^{721}$

O Brasil, nos acordos contra bitributação em que foi signatário, adotou um conceito amplo de royalties, que abrange também as remunerações relativas a formas de propriedade industrial, locação de equipamentos e direito do próprio autor, aproximando-se da definição contida na Convenção Modelo da ONU, receitas sobre as quais se reserva o direito de tributar, ainda que limitadamente. A posição brasileira pode ser explicada pela ampliação da base de cálculo do imposto sobre a renda incidente na espécie, decorrente do alargamento do conceito de royalties.

No entanto, como nosso estudo é voltado aos impostos sobre o consumo, cuja competência impositiva foi distribuída entre os entes da Federação, interessa-nos distinguir a natureza jurídica destes "bens digitais" objeto do comércio eletrônico direto, para que se defina se ocorre uma prestação de serviços ou circulação de mercadorias, hábeis a percutir tributariamente na aquisição da cessão ou licença de tais objetos.

A constatação de que, por determinação legal, os programas de computador não podem ser objeto de contratos de compra e venda com o usuário final, mas somente de mero licenciamento, é de fundamental relevância em nosso estudo sobre a incidência tributária no âmbito das transações envolvendo bens digitais.

Desta forma, descartamos de nossa análise os contratos de compra e venda, passando a investigar a natureza jurídica dos bens digitais obtidos nos contratos de cessão, locação e licença de uso.

\subsubsection{Bens Digitais e o ICMS}

O fulcro deste estudo sobre a tributação dos bens digitais perpassa pela questão do ICMS, ainda que o referido imposto não esteja no bojo do escopo deste trabalho. Desta forma e considerando as discussões sobre a tributação do software, impõe-

721 No original: The term royalties as used in this article means payments of any kind received as a consideration for the use of, or the right to use, any copyright of literary, artistic or scientific work including cinematograph films, any patent, trade mark, design or model, plan secret formula or process or for information concerning industrial, commercial or scientific experience. Convenção Modelo OCDE - Artigo 12 - Item 2. Disponível em: 〈http://www.oecd.org/dataoecd/14/32/41147804.pdf>. Acesso em 24 de abril de 2010. 
se a investigação sobre a incidência do ICMS na disponibilização de bens digitais, ainda que de modo sucinto.

Recordando as premissas já fixadas, nestas operações, que se desenvolvem de maneira integralmente eletrônica, um software ou obras digitais são objeto de um negócio jurídico que, conforme analisamos, podem constituir uma cessão, licença ou locação nos termos do art. 49 da Lei de Direitos Autorais.

Para que haja a subsunção dos fatos jurídicos ali ocorridos à norma geral e abstrata fixada pelo constituinte originário para o ICMS, tais transações devem constituir-se em "operações mercantis" e os bens digitais considerados como "mercadorias".

Por outro giro, para que a cessão de direitos, a locação e a licença de uso de bens digitais se enquadrem na materialidade do ICMS, estes negócios jurídicos deverão representar operações mercantis e ser praticados por uma pessoa com habitualidade ou volume que caracterize o intuito comercial.

Apesar de o artigo 10 da Lei $\mathrm{n}^{\circ}$ 9.609/98 referir-se a estes negócios jurídicos com a expressão "comercialização referente a programas de computador", não se pode afirmar que teria sido atribuído ao licenciamento um regime mercantil, tratando-se de mais uma atecnia do legislador, que se utilizou da expressão em seu sentido não-jurídico. 722

Os direitos intelectuais relativos aos bens digitais dizem respeito à criação e utilização da obra e não ao corpus mechanicum no qual se exterioriza; além disto, vários direitos do autor não são alienáveis, de modo que, como já afirmamos, os bens digitais não podem ser objeto de contratos de compra e venda. Ao adquirente de uma licença ou cessão de uso "compete a fruição em seu ambiente privado e para fins próprios, não podendo fazer qualquer uso que importe em circulação econômica. ${ }^{723}$

Qualquer uma das modalidades que eleger o criador de um bem digital para comunicar sua obra, previstas no art. 29 da Lei de Direitos Autorais, constituirá operação desprovida de caráter mercantil, recaindo o interesse do adquirente no uso do bem.

Destarte, não pode ocorrer a subsunção dos fatos jurídicos relativos aos negócios de licenciamento de bens digitais à hipótese de incidência do ICMS, já que no

\footnotetext{
${ }^{722}$ Cf. EMERENCIANO, Adelmo da Silva, op. cit. (nota 39), p. 151.

${ }^{723}$ Cf. Idem, ibidem, p. 153.
} 
campo denotativo da expressão "realizar operações", não se contemplam as hipóteses de licenciamento aqui tratadas.

Ademais, a "circulação" expressa na hipótese do imposto é aquela circulação jurídica e não física ou econômica, pressupondo a troca de titularidade do bem decorrente de compra e venda, troca, consignação e outras operações, o que não ocorre no licenciamento de bens digitais. Nesta modalidade de operacionalização, confere-se apenas o direito de uso do bem, não sendo alienada a propriedade do bem.

No tocante à natureza de "mercadoria", necessária à configuração da hipótese de incidência do ICMS, nos termos dos artigos da Lei Complementar n 87/96, norma geral relativa ao tributo, pode-se extrair que o significado de mercadoria abrange as seguintes características:

(i) coisa móvel; (ii) corpórea; (iii) indiferente à circunstância de estar industrializada ou não; (iv) objeto de um negócio jurídico que lhe determine a transferência de titularidade; (v) negócio este cuja habitualidade ou volume revele intuito comercial; (vi) que tenha como destino ser revendida e (vii) mesmo se importada para consumo ou para compor o ativo fixo do estabelecimento empresarial.

Já afirmamos que os bens digitais são bens móveis por determinação legal; também já concluímos que não se tratam de bens corpóreos no sentido que lhe é atribuído pelo direito civil, não podendo ser confundidos com as mídias em que são inseridas.

Também já verificamos que, nos contratos de licenciamento, não ocorre a transferência da titularidade do bem, concedendo-se somente o direito de utilizá-lo. Portanto, cremos já haver demonstrado que, pela ausência de várias das características a elas inerentes, os bens digitais não podem ser considerados "mercadorias" no sentido utilizado pelo texto constitucional para atribuir a competência impositiva aos Estados.

Desta forma, estamos autorizados a concluir que não incide o ICMS sobre os negócios jurídicos de licenciamento de bens digitais, não ocorrendo a perfeita subsunção dos fatos ali descritos à hipótese da regra-matriz do imposto.

De modo símile, também sobre a cessão de direitos não incide o imposto sobre a circulação de mercadorias. Nos contratos de cessão, são transferidos a terceiros, 
por título oneroso ou não, um ou mais dos direitos patrimoniais do autor sobre sua criação, permitindo-se ao cessionário a exploração econômica do bem.

Nos negócios jurídicos de cessão de direitos, não se transfere o domínio sobre uma mercadoria, mas os direitos patrimoniais, considerados como direitos reais, embora sobre bens incorpóreos, tido como bens móveis por força do art. $3^{\circ}$ da Lei $\mathrm{n}^{\circ}$ 9.610/98. Portanto, não pode incidir sobre tais operações o Imposto sobre Circulação de Mercadorias.

Por fim, devemos examinar a locação dos bens digitais, autorizada pelo $\S$ $5^{\circ}$ do art. $2^{\circ}$ da Lei $n^{\circ}$ 9.609/98. De plano se pode afirmar que o ICMS não incide sobre a locação de mercadorias, já que, nesta modalidade de negócio jurídico, não há a transferência de propriedade do bem, não se configurando o fato jurídico capaz de desafiar a incidência do ICMS.

No tocante à locação de bens digitais, trata-se de inovação no sistema jurídico brasileiro, já que a locação tem como objeto coisa não fungível, conforme teor do disposto no art. 565 do Código Civil. Já vimos que o software é bem fungível, de modo que não pode ser objeto de locação.

Portanto, concluímos que, nos negócios jurídicos que envolvem bens digitais realizados por meio da cessão ou licenciamento, não incide o ICMS.

\subsubsection{Bens Digitais e o ISS}

Perquirir se incide o ISS nas operações do comércio eletrônico direto significa "verificar a similitude entre as características do fato ocorrido e os predicados selecionados pelo editor normativo ao elaborar a hipótese da norma". ${ }^{725}$ Verificada a concorrência entre os fatos jurídicos relativos aos bens digitais e a descrição contida na hipótese da regra-matriz de incidência do Imposto sobre Serviços, significa que a competência tributária ativa em relação a tais fatos pertence aos Municípios.

Vimos que os bens digitais são, por determinação legal, bens móveis tutelados pelo regime dos direitos autorais, cuja fruição opera-se por meio de contratos de licença de uso, cessão de direitos ou locação.

${ }^{725}$ ARAUJO, Clarice Von Oertzen, op. cit. (nota 23), p. 31. 
No âmbito da Comunidade Europeia e nos tratados que seguem a Convenção Modelo da OCDE, as operações cujo resultado seja colocar um produto à disposição do destinatário em forma digital, mediante uma rede eletrônica, devem ser enquadradas como prestação de serviço. No entanto, vimos no item 4.2.4 que, desde a origem, a estrutura do IVA é diversa daquela do ISS; o critério material do tributo europeu abrangia as transmissões de bens e as prestações de serviços a título oneroso.

A transmissão de bens, por expressa definição legal, compreendia "a transferência do poder de disposição de um bem material como proprietário", sendo que o campo de incidência das operações de "prestação de serviços" era definido por exclusão àquela definição, abrangendo "toda operação que não constitua transmissão de um bem no sentido do art. $5^{\circ}$ ". De modo geral, o imposto onerava tanto as vendas de bens materiais (mercadorias ou produtos) como de bens imateriais (serviços).

No Brasil, o conceito de prestação de serviços é associado pela doutrina a uma obrigação de fazer; no entanto, vimos no item 5.6 que, em recente pronunciamento, o Supremo Tribunal Federal definiu a extensão da expressão "serviços de qualquer natureza" no RE 547.245, relativo à incidência do ISS nos contratos de leasing.

Naquele julgado, o relator definiu que a Lei Complementar mencionada pela CF no artigo 156, III, arrola (i) serviços por natureza; (ii) inclui serviços que, não exprimindo a natureza de outro tipo de atividade, passam à categoria de serviços, para fins de incidência do tributo, por força de lei, visto que, se assim não considerados, restariam incólumes a qualquer tributo; e (iii) em caso de operações mistas, afirma a prevalência do serviço, para fins de tributação pelo ISS. Desta forma, "são serviços assim conceituados por força da própria lei, configurando atividades que, em si mesmas, não revestem essa natureza, mas que, também, não exprimem, rigorosamente, a natureza de outro tipo de atividade diferentemente tributada [...] que ficariam a cobro de qualquer exação fiscal", 726

Segundo a decisão, exarada em regime de repercussão geral, a lei complementar apenas declara o que é serviço para fins do inciso III do artigo 156 da Constituição.

Neste sentido, relativamente à incidência do Imposto Sobre Serviços nas operações cujo objeto é um bem imaterial realizadas por meio de cessão e licença de uso, a

\footnotetext{
${ }^{726}$ Trecho do Parecer do Min. Ilmar Galvão no voto do Min. Eros Grau no RE 547.245/SC.
} 
Lei Complementar $n^{\circ} 116 / 2003$ prevê em sua Lista de Serviços anexa dois itens relacionados aos institutos jurídicos.

O subitem 1.05, relativo ao item 1, que agrupa atividades de informática e congêneres, abarca os serviços de "licenciamento ou cessão de direitos de uso de programas de computador". Além disto, no item 10, relativo a serviços de intermediação e congêneres, há o subitem 10.03, que abrange os serviços de "agenciamento, corretagem ou intermediação de direitos de propriedade industrial, artística ou literária”.

No mercado de programas de computador, grandes empresas do ramo de softwares denominados "de prateleira" têm negociado seus produtos, diferenciando-os em função da forma: arquivos digitais ou mídias físicas. ${ }^{727}$ Caso o comprador opte por adquirir um pacote de software em uma loja física, contido em um CD, considera-se que está sendo adquirida uma mercadoria, incidindo sobre o valor da aquisição o Imposto sobre Circulação de Mercadorias. No entanto, se o usuário acessar o site da empresa e adquirir o programa por meio do comércio eletrônico direto via download do software, a operação é classificada como licenciamento de direitos de uso de software, incidindo na aquisição o Imposto Sobre Serviços, nos termos do disposto na legislação complementar, item 1.05 da Lista de Serviços.

Ressalte-se que a tributação diferenciada dos produtos virtuais constitui uma violação ao Principio da Neutralidade, que orienta as operações do comércio eletrônico internacional, garantindo que tais operações não sejam tributadas de maneira mais gravosa, nem mais favorável, do que aquelas realizadas pela forma tradicional de comércio.

Também os Fiscos municipais têm sido instados a se manifestar sobre as operações relativas a bens digitais; o Município de São Paulo, na Solução de Consulta SF/DEJUG No 25 de 17 de junho de 2008, relativa à incidência do ISS no licenciamento de direito de uso de imagens a usuários finais por meio de sites na Web, concluiu pela não incidência do ISS sobre as operações.

727 O site da Microsoft disponibiliza a atualização on-line do sistema operacional Windows 8 Pro por determinado custo, alertando os usuários de que, caso optem por comprar a mídia de atualização em um varejista local, "o preço praticado é diferente da versão de download e pode variar de acordo com o varejista". Disponível em: <http://windows.microsoft.com/pt-BR/windows-8/terms-conditions $>$. Acesso em 3 de novembro de 2012. 
O processo de consulta tributária tem como escopo a obtenção por parte do contribuinte de uma manifestação da Administração sobre dúvida por ele suscitada a respeito da aplicação da legislação tributária a determinado caso concreto.

Naquele procedimento, analisando os contratos apresentados pela consulente, o Fisco Municipal detectou duas relações jurídicas distintas; na primeira, estabelecida entre os autores ou detentores dos direitos das imagens e a agência distribuidora, os licenciantes (ou fornecedores) concedem à consulente uma licença não exclusiva para o sublicenciamento de imagens de "Direitos Administrados a Usuários Finais" por meio de seus sites na web ou outros métodos de distribuição.

A outra relação jurídica se estabelece entre a consulente e seus clientes, cujo contrato tem a natureza jurídica de licença de uso, figura a consulente como intermediária entre os autores ou detentores dos direitos sobre determinadas imagens (fotos ou filmes) e os usuários finais interessados em utilizar estas imagens.

Desta forma, nos termos da mencionada Solução de Consulta, a consulente seria prestadora de serviços de intermediação, enquadrável no subitem 10.03 relativo a agenciamento, corretagem ou intermediação de direitos de propriedade industrial (inclusive marcas e patentes), artística ou literária, código de serviço 06173 do Anexo I da Portaria SF $n^{\circ} 14 / 2004$. Restou assim definido que sobre os contratos firmados com seus fornecedores (detentores dos direitos das imagens) há incidência do ISS à alíquota de $5 \%$ (cinco por cento) sobre o preço dos serviços. ${ }^{728}$

De fato, a distribuição de bens digitais é habitualmente realizada por terceiros intermediários, que atuam como distribuidores, relacionando-se de uma parte com o licenciante e de outra com os consumidores finais, evitando o contato direto destes com o autor. Os intermediários não possuem a propriedade dos bens digitais e representam os interesses do autor, atuando na celebração de contratos de licenciamento de uso, avençados na maior parte das vezes de forma automática, por meio dos sites. ${ }^{729}$

Considerando-se que os direitos autorais reputam-se para os efeitos legais como bens móveis, nos termos do art.3 da Lei Federal n 9.610/1998, conclui o parecer que "a cessão de direitos autorais é equiparada à prestação de serviços de locação de bens

\footnotetext{
${ }^{728}$ Nos termos do inciso IV do Art. 16 da Lei $n^{\circ}$ 13.701, de 24/12/03, acrescido pela Lei $n^{\circ} 14.668$, de $14 / 01 / 08$

${ }^{729}$ Cf. EMERENCIANO, Adelmo da Silva, op. cit. (nota 39), p. 155.
} 
móveis" e que, "a partir da vigência da Lei Complementar n 116/03, deixou de incidir o ISS sobre as receitas decorrentes da prestação de serviços de locação de bens móveis".

Observe-se que há no parecer uma imprecisão terminológica empregando indistintamente como sinônimos três institutos jurídicos distintos: a licença de uso, a cessão de uso e a locação.

Vimos no item 2.4.1 deste trabalho que a cessão de direitos não se confunde com a licença de uso; esta abarca somente a concessão do exercício de direitos, enquanto a cessão é contrato de transferência da propriedade.

$\mathrm{O}$ assunto da tributação dos bens digitais também tem sido levado ao Judiciário, e o Supremo Tribunal Federal reconheceu recentemente repercussão geral relativamente à questão da incidência do ISS sobre o licenciamento de direitos e cessão de uso relativos a programas de computador (software) personalizados. ${ }^{730}$ Desta forma, a decisão proveniente do Recurso Extraordinário $n^{\circ}$ 688.223/PR será aplicada posteriormente pelas instâncias inferiores, em casos idênticos. A ementa da Repercussão Geral restou assim ementada:

RE 688223 RG / PR - PARANÁ - REPERCUSSÃO GERAL NO RECURSO EXTRAORDINÁRIO- Relator(a): Min. LUIZ FUX Julgamento: 20.09.2012.

DIREITO CONSTITUCIONAL E TRIBUTÁRIO. LICENCIAMENTO OU CESSÃO DE DIREITO. PROGRAMAS DE COMPUTADOR PERSONALIZADOS (SOFTWARE). INCIDÊNCIA DE ISS. ARTIGO 156, III, DA CONSTITUIÇÃO FEDERAL. MANIFESTAÇÃO PELA REPERCUSSÃO GERAL.

No julgado, foi tomado como paradigma o REsp n ${ }^{\circ} 814.075$ do Superior Tribunal de Justiça. Vejamos o acórdão:

PROCESSUAL CIVIL E TRIBUTÁRIO. OMISSÃO DO ARESTO DE APELAÇÃO. INOCORRÊNCIA. NULIDADE DA CDA. AUSÊNCIA DE LANÇAMENTO. LOCAL DA PRESTAÇÃO DOS SERVIÇOS. CONTROVÉRSIA DIRIMIDA COM BASE EM ELEMENTOS FÁTICOS. REEXAME. IMPOSSIBILIDADE. INCIDÊNCIA DA SÚMULA N. ${ }^{\circ}$ 07/STJ. FORNECIMENTO DE PROGRAMAS DE COMPUTADOR - SOFTWARE. PRESTAÇÃO DE SERVIÇOS. ISS.

${ }^{730}$ DICIONÁRIO JURÍDICO DO STF. Verbete Repercussão Geral: “A Repercussão Geral é um instrumento processual inserido na Constituição Federal de 1988, por meio da Emenda Constitucional 45, conhecida como a "Reforma do Judiciário". O objetivo desta ferramenta é possibilitar que o Supremo Tribunal Federal selecione os Recursos Extraordinários que irá analisar, de acordo com critérios de relevância jurídica, política, social ou econômica". Disponível em: $<$ http://www.stf.jus.br/portal/glossario/ververbete.asp?letra=r\&id=451 >. Acesso em 7 de novembro de 2012. 
INCIDÊNCIA. ALEGAÇÃO DE QUE SE TRATA DE CONTRATO DE CESSÃO DE USO. IMPROCEDÊNCIA.

1. O fornecimento de programas de computador (software) desenvolvidos para clientes de forma personalizada se constitui prestação de serviços sujeitando-se, portanto, à incidência do ISS.

$[\ldots]$

O tema fulcral do recurso admitido como paradigma no sistema de repercussão geral é a incidência do tributo municipal sobre licenças de uso de programas de computador, adquiridas no exterior por empresa do ramo de telecomunicações para planejamento de redes de telecomunicações celulares. Na admissão do recurso, alegou o Ministro Relator Luiz Fux que "as operações e contratos utilizando a cessão ou licenciamento por uso de computador, em serviço personalizado, abrange quantidade significativa de empresas, necessitando o pronunciamento desta Corte”. ${ }^{731}$

Analisamos neste trabalho a proposta de uma nova visão a ser considerada na tributação de serviços, elaborada por Greco, que altera o foco da natureza ou dimensão da atividade, para a "utilidade" a ser obtida com a prestação do serviço. Desta forma, a noção de prestação de serviço passaria a ser vista como um fornecimento de utilidades, ainda que imateriais, abarcando, desta forma, os bens digitais.

Nosso ordenamento jurídico parece incorporar esta visão quando determina que as operações do comércio eletrônico direto realizadas pelo licenciamento e a cessão de direitos de uso de programas de computador, assim como as atividades de agenciamento, corretagem ou intermediação de direitos de propriedade industrial, artística ou literária a elas relacionadas, estão sujeitas à tributação pelo Imposto sobre Serviços de Qualquer Natureza, por expressa previsão na Lista de Serviços Anexa à LC n 116/2003.

\subsubsection{Cloud Computing: Natureza Jurídica}

Vimos neste trabalho que surgiu no mercado uma nova modalidade de disponibilização de recursos de informática: a cloud computing. Estas novas tecnologias estão sendo absorvidas no mercado nacional com a natureza jurídica a elas atribuída no exterior, ou seja, como serviços, sem que tenham sido desenvolvidos no campo tributário

${ }^{731}$ Trecho do voto do Min. Relator Luiz Fux, no RE 688.223/PR, em 12.09.2012, p. 4. Disponível em: <www.stf.jus.br〉. Acesso em 7 de novembro de 2012. 
quaisquer estudos para determinar a essência do instituto com o intuito de classificá-lo dentro do universo de figuras existentes no Direito.

Este novo "fenômeno" na área da tecnologia está deslocando dos microcomputadores dos usuários, ou dos servidores de dados das empresas, para "as nuvens", os arquivos, programas, o processamento e outras tarefas correlatas.

Conceituamos cloud computing como um vasto conjunto de recursos que abarca servidores, impressão, armazenamento, processamento, softwares e também processos.

Já verificamos também que a arquitetura em cloud exige uma complexa infraestrutura de gerenciamento, que inclui, entre outras, as funções de provisionamento dos recursos computacionais, monitoração do desempenho e controle do fluxo de trabalhos que serão processados em um ambiente computacional na nuvem de processamento, e o retorno do trabalho realizado, direcionado ao dispositivo de saída do solicitante (workload).

Vale dizer, alguém assume a responsabilidade de prover várias funções de TI como serviços para alguns clientes, que não precisam conhecer o modelo ou possuir equipe e equipamentos próprios.

Estes serviços podem ser disponibilizados aos usuários por meio de um “servidor virtual”, tema que ainda não foi objeto de estudo da OCDE nem da doutrina. Um servidor virtual permite que uma entidade com um web site tenha seu próprio nome de domínio e um endereço IP, bem como administre seus próprios arquivos e domínios, gerindo seus próprios registros, elaborando análises estatísticas e mantendo senhas. ${ }^{732}$

No entanto, os usuários de um "servidor virtual" não possuem qualquer gestão sobre os aspectos de hardware relacionados ao serviço, já que o contrato para sua utilização concede à empresa o direito de utilização do servidor.

Neste compasso, impende investigar a natureza jurídica das relações estabelecidas no modelo cloud computing e suas derivações, abordadas no item 2.4.2 deste trabalho. Salientamos que, tratando-se de uma nova modalidade, não existem ainda estudos sobre os aspectos jurídicos envolvidos, nem literatura técnica suficiente a fornecer subsídios capazes de alicerçar um estudo robusto sobre o tema, de forma que nos

${ }^{732}$ Cf. PINTO, Dale, op. cit. (nota 288), p. 50. 
limitaremos a traçar as primeiras considerações sobre o tema, que merece um estudo específico e aprofundado.

Os manuais técnicos comparam a remuneração paga pelos usuários no cloud computing a uma "assinatura", que nos remete à sistemática da prestação de serviço de TV a cabo. A Lei n ${ }^{\circ} 12.485$ de 2011 dispõe que a TV a cabo hoje é considerada como um Serviço de Acesso Condicionado - SeAC, que constitui

o serviço de telecomunicações de interesse coletivo, prestado no regime privado cuja recepção é condicionada à contratação remunerada por assinantes e destinado à distribuição de conteúdos audiovisuais na forma de pacotes, de canais de programação nas modalidades avulsa de programação e avulsa de conteúdo programado e de canais de programação de distribuição obrigatória, por meio de tecnologias, processos, meios eletrônicos e protocolos de comunicação quaisquer. ${ }^{733}$

Portanto, tratando-se de serviço de telecomunicações, encontra-se no campo de incidência do ICMS. Mas a questão da natureza jurídica dos serviços abrangidos nos pacotes domésticos de TV a cabo já foi levada ao STF.

$\mathrm{Na}$ época, a decisão baseou-se na definição legal do art. $2^{\circ}$ da Lei 8.977/95, que considerava a TV a cabo como "um serviço de telecomunicações, que consiste na distribuição de sinais de vídeo e/ou áudio, a assinantes, mediante transporte por meios físicos".

Decidiu o relator, portanto, que o serviço de TV a cabo desafia a imposição do ICMS, na forma prevista pelo art. 155, II da Constituição Federal, excluindo desta tributação os valores cobrados a título de taxa de adesão. ${ }^{734}$ Desta forma, a analogia proposta do cloud computing à TV a cabo não se aplica ao tema, devendo ser afastada.

Numa outra abordagem poderíamos vislumbrar no sistema de disponibilização dos recursos uma locação, cuja remuneração corresponderia a um aluguel. Na locação de coisa, disciplinada pelo Código Civil, há a cessão de uma “coisa”, por

\footnotetext{
733 Anatel, SeAC - Serviço de Acesso Condicionado, Disponível em: <http://www.anatel.gov.br/Portal/exibirPortalPaginaEspecial.do?acao=\&codItemCanal=1714\&codigoVis ao=4\&nomeVisao=Cidad\%E3o\&nomeCanal=TV\%20por\%20Assinatura\&nomeItemCanal=SeAC $>$. Acesso em 5 de dezembro de 2012.

${ }^{734}$ Trecho da decisão monocrática do Relator Min. Dias Toffoli no RE n 466887 PR.
} 
tempo determinado, que deverá ser restituída ao final do contrato, no estado em que recebeu. ${ }^{735}$

Já mencionamos que no sistema cloud são disponibilizados softwares, infraestrutura, banco de dados, abrangendo praticamente todos os recursos e equipamentos necessários para as atividades de uma empresa, que deve possuir somente um dispositivo de acesso (personal computer, tablet, smartphone, etc.) que lhe possibilite utilizar os recursos necessários. Na fruição desta estrutura, o usuário do sistema cloud nada detém ou poderá restituir ao final do contrato.

Parece-nos que quando o sujeito legitimado por um contrato de cloud acessa a estrutura que lhe é disponibilizada terá à sua disposição, além dos recursos tecnológicos, um gerenciamento individualizado de suas necessidades e de sua utilização efetiva, de forma que são executadas atividades que podem ser entendidas como "prestações de serviços".

Além disto, vimos que a locação em nosso sistema jurídico é restrita a coisas não fungíveis.

Ao contrário do que ocorre no fornecimento de bens digitais no comércio eletrônico direto, no cloud computing os recursos são disponibilizados aos usuários de forma não automática, havendo uma grande estrutura de gerenciamento e controle que é absorvida pela empresa.

Na medida em que atende às necessidades dos usuários em todas as áreas de informática, a computação em nuvem substituiria a equipe de TI necessária para gerir os serviços de informática de uma empresa, de forma que suas atribuições são absorvidas pela estrutura de nuvem, o que nos possibilita visualizar que há no modelo, de forma nítida, uma prestação de serviços.

Corroborando nossa conclusão, foi apresentado ao Congresso em 08.05.2012 o Projeto de Lei Complementar $n^{\circ}$ 171/12, que altera a LC $n^{\circ} 116 / 2003$, para incluir na lista de serviços o item "computação em nuvem", descrito como "serviços na Internet que não requerem conhecimento, do consumidor, quanto à localização física e configuração do sistema". 736

735 Artigo 569, IV do Código Civil Brasileiro, Lei $\mathrm{n}^{\circ}$ 10.406/2002. “O locatário é obrigado: [...] IV - a restituir a coisa, finda a locação, no estado em que a recebeu, salvas as deteriorações naturais ao uso regular."

736
Projeto
de Lei
Complementar
$\mathrm{n}^{\circ}$
171/12.
Disponível
em: <http://www.camara.gov.br/proposicoesWeb/prop_mostrarintegra;jsessionid=9D033CB633EAFDB9552 
$\mathrm{O}$ autor do projeto entreviu a necessidade de definir a tributação desta nova modalidade de serviços, considerando a disputa entre a incidência do ICMS e do ISS sobre serviços de tecnologia da informação e da comunicação e software. ${ }^{737}$

A definição inserida no projeto estabelece que "computação em nuvem consiste na oferta de serviços, em ambiente de Internet, como processamento de dados e uso de softwares, sem exigir conhecimento do consumidor quanto à localização física e configuração do sistema que presta os serviços". Ressalta ainda o projeto que o requisito mínimo é um computador compatível com os recursos disponibilizados.

Como já havíamos abordado, o projeto alerta que o desenvolvimento de novas tecnologias pode estabelecer dúvidas sobre o tratamento tributário adequado aos novos produtos e serviços.

O projeto considera as três principais operações em nuvem, IaaS, PaaS e SaaS (que descrevemos no bojo do item 2.4.2) e analisa as atividades à luz de nosso ordenamento jurídico, concluindo pela necessidade da inclusão de um item específico relativo ao serviço. Considerou-se que a interpretação de que os serviços de IaaS, relativos à utilização de uma infraestrutura em computação como um serviço, com disponibilidade de capacidade de armazenamento fornecida pelo servidor, de acordo com a necessidade do cliente, poderiam estar abrangidos no item 1.03 da Lista de Serviços, "processamento de dados e congêneres", abriria uma discussão sobre a incidência do imposto.

O SaaS, que se constitui a utilização de forma remota de softwares hospedados na nuvem por meio da Internet, sem a necessidade de download, poderia, segundo a justificativa do projeto de lei, ser enquadrado no item 1.05 da $\mathrm{LC}^{\circ}$ 116/2003, que prevê o "licenciamento ou cessão de direito de uso de software".

No tocante ao PaaS, que consiste na utilização de uma plataforma de computação atrelada a um pacote de soluções voltadas ao desenvolvimento, teste e entrega de softwares, trata-se de serviço complexo que envolve o processamento de dados, o armazenamento e o licenciamento de software, além dos testes dos softwares desenvolvidos, envolvidos em uma contratação indivisível. Segundo o documento, tratamse de "meras atividades-meio" que possibilitam o serviço principal contratado, o PaaS.

F8A236D70F093.node2?codteor=989431\&filename=Tramitacao-PLP+171/2012 >. Acesso em 10 de dezembro de 2012.

737 Congresso pode Taxar Nuvem, Disponível em: <http://convergenciadigital.uol.com.br/cgi/cgilua.exe/sys/start.htm?infoid=30888\&sid=97>. Acesso em 10 de dezembro de 2012. 
Desta forma, ainda que algumas atividades como o processamento e o licenciamento estejam previstas expressamente na Lei Complementar $n^{\circ}$ 116/2003, prevaleceria o serviço complexo não previsto na Lista Anexa.

Por fim, ressalta que se aplica a estes novos serviços o conceito de "utilidade", que norteia o relacionamento entre os contratantes, já que o objetivo é atender às necessidades pontuais dos usuários, fornecendo a utilidade almejada.

Analisando a incidência do ISS sobre a exportação dos serviços de hospedagem em banco de dados, suporte técnico, assessoria e consultoria, concluiu Humberto Ávila que "não há dúvida alguma de que esses serviços constituem obrigações de fazer com a finalidade de criar utilidade para tomador localizado no exterior". Vale dizer, reconheceu que serviços similares àqueles prestados no modelo cloud constituem prestações de fazer que consistem em utilidades para o tomador, de modo que desafiam a incidência do imposto municipal. ${ }^{738}$

\subsubsection{O Critério Espacial}

A problemática relativa ao critério espacial no comércio eletrônico direto, de regra, é a "inexistência" de um estabelecimento físico, já que nesta sistemática o estabelecimento físico não tem qualquer relevância no aperfeiçoamento do negócio.

De modo geral, todas as considerações e conclusões alcançadas no item 6.4, relativas ao comércio eletrônico indireto, sobre a fixação do ente competente para exigir o ISS relativamente aos estabelecimentos virtuais e servidores de dados, aplicam-se à "prestação de serviços eletrônica" e ao fornecimento de bens digitais, abarcados pelo comércio eletrônico direto.

\subsection{Estudo de Casos: Aplicação dos Critérios}

Definidos os pressupostos teóricos e propostas as soluções para cada uma das situações possíveis no comércio eletrônico relativamente à definição da materialidade e a de sua localização espacial, passaremos a testá-los em alguns arquétipos de atividades de 
prestação de serviço, que têm sofrido impactos em função da incorporação da tecnologia da informação e da comunicação.

\subsubsection{Monitoração Eletrônica de Pessoas}

A Lei $n^{\circ} 12.258$ de 15 de junho de 2010 alterou a Lei de Execuções Penais vigente acrescentando-lhe dispositivo que permite que a vigilância dos presos em regime semiaberto seja feita por monitoração eletrônica. Vejamos o teor do dispositivo, que acrescentou os artigos 146-B e 146-C à Lei no 7.210, de 11 de julho de 1984:

Art. 146-B. O juiz poderá definir a fiscalização por meio da monitoração eletrônica quando:

I - (VETADO);

II - autorizar a saída temporária no regime semiaberto;

III - (VETADO);

IV - determinar a prisão domiciliar;

$\mathrm{V}$ - (VETADO);

Art. 146-C. O condenado será instruído acerca dos cuidados que deverá adotar com o equipamento eletrônico e dos seguintes deveres:

I - receber visitas do servidor responsável pela monitoração eletrônica, responder aos seus contatos e cumprir suas orientações;

II - abster-se de remover, de violar, de modificar, de danificar de qualquer forma o dispositivo de monitoração eletrônica ou de permitir que outrem o faça;

III - (VETADO).

A vigilância, segurança ou monitoramento de bens e pessoas é um dos serviços previstos na Lista Anexa à Lei Complementar no 116 de 2003, que constitui exceção à regra geral quanto ao critério espacial do ISS (estabelecimento prestador), sendo o imposto devido, nos termos do inciso XVI do art. $3^{\circ}$ da referida norma, "no local dos bens ou do domicílio das pessoas vigiados, segurados ou monitorados".

Com a aprovação do novo sistema eletrônico, imaginemos a seguinte situação, não hipotética: determinado Estado da Federação, responsável pela segurança pública, contrata em processo licitatório empresa especializada em monitoramento eletrônico, cuja sede localiza-se em Município de outro Estado. O caso é levado à Solução de Consulta pelo órgão estadual, ao Fisco do Município em que tem sede o governo, questionando o local onde incide o Imposto sobre Serviços no contrato que seria então celebrado: (i) no Município em que está situado o órgão de segurança, responsável pela guarda dos detentos, (ii) naquele em que se localiza a central eletrônica que capta os sinais 
eletrônicos das referidas tornozeleiras, via satélite ou (iii) em cada um dos municípios do referido Estado em que residam presos que utilizem o referido artefato, já que o sinal captado pela central de monitoramento é gerado por cada uma das tornozeleiras.

No exemplo consignado, vislumbramos ao menos três locais possíveis para ocorrer a incidência do Imposto sobre Serviço. Pela dicção da Lei Complementar, no serviço de monitoramento de pessoas, uma das exceções à regra geral do critério espacial, o Imposto sobre Serviços incide no local do domicílio das pessoas vigiadas. No caso dos presos, o domicílio "necessário", nos termos do art. 76 do Código Civil Brasileiro, é "o lugar em que cumprir pena". 739

Desta forma, com a concessão do benefício do regime semiaberto ou da prisão domiciliar, os presos estariam "cumprindo" suas penas fora dos estabelecimentos prisionais, possivelmente em suas residências, de modo que o ISS seria devido em cada Município brasileiro em que houver um usuário da tornozeleira eletrônica.

O sistema de tornozeleiras eletrônicas possibilita que os condenados deixem o presídio, resguardando o sistema prisional e a própria sociedade, de fuga ou reiteração delitiva. Os referidos artefatos eletrônicos efetuam a tutela do preso, representando o Estado, permitindo que eles ganhem a liberdade mesmo estando sob a responsabilidade deste. Desta forma, a utilização do recurso tecnológico tem como função substituir a tutela presencial do Estado, transferindo-a para o local onde estiver sediada a central de monitoramento.

Portanto, o local onde estiver estabelecida a central de monitoramento, que capta os sinais eletrônicos enviados por cada um dos equipamentos, representa o local onde as pessoas estão sendo vigiadas, em substituição à monitoração presencial. Esta central se configura como o local onde estão sendo monitorados os presos e, portanto, prestado o serviço, de forma que a competência ativa para sua tributação pertence ao Município onde se localizar a central de monitoração eletrônica.

739 Art. 76 da Lei $\mathrm{n}^{\circ}$ 10.406, de 10.01.2002: “Têm domicílio necessário o incapaz, o servidor público, o militar, o marítimo e o preso". Domicílio necessário é aquele determinado por lei, em razão da condição ou situação de certas pessoas. 


\subsubsection{Laboratórios de Análises Clínicas: análise à distância computadorizada}

Em função das facilidades concedidas por alguns Municípios num ambiente de guerra fiscal, alguns centros de análises clínicas têm cindido suas atividades, transferindo parte delas para servidores de dados que realizam a análise dos materiais biológicos coletados. De modo geral, estes servidores são instalados em Município diverso daquele onde se localiza o estabelecimento da empresa em que é realizado o atendimento ao público e a coleta de materiais.

O assunto tem sido levado ao Judiciário, cujas decisões, que ainda se encontram nas instâncias inferiores, apontam no sentido de que a base de cálculo não pode ser cindida entre os dois Municípios, cabendo a tributação àquele em que se efetivam as análises, ou seja, aonde se localizam as centrais de diagnósticos, no caso, onde está instalado o servidor de dados. Vejamos o teor de uma destas decisões:

Apelação $n^{\circ}$ 0123273-75.2007.8.26.0000 (994.07.123273-2) - Comarca de São Vicente /SP - Recorrente: Juízo "ex officio"

Apelante/apelada: Prefeitura Municipal de São Vicente

Apelante/apelado: Instituto de Análises Clínicas de Santos Ltda.

AÇÃO ANULATÓRIA - ISS - Exercício de 2007 - Município de São Vicente - Reexame necessário - Descabimento - Aplicação do artigo 475, $\S 2^{\circ}$, do CPC - Coleta de materiais biológicos, em simples posto de atendimento para este fim - Mera atividade-meio para a consecução dos serviços de análises clínicas realizados em laboratório instalado no município de Santos - Não incidência daquele imposto sobre tal ato preparatório - Incompetência da ré, ademais, para tributar dita atividade-fim, por interpretação dos artigos $3^{\circ}$ e $4^{o}$ da LC $n^{\circ} 116 / 03$ - Nulidade do lançamento Tributação indevida - Procedência do pleito inicial nesta sede Sucumbência cominada à vencida - Sentença reformada em parte Recurso oficial não conhecido, apelo do contribuinte provido e apelo da municipalidade prejudicado.

Apelação n 0123273-75.2007.8.26.0000 - Voto nº 14665 - Des. SILVA RUSSO.

O conflito tem sido solucionado pelo Judiciário com base no critério da atividade- meio/atividade-fim. Neste diapasão, a doutrina de Aires F. Barreto:

Se algumas atividades acessórias, tarefas-meio, forem desenvolvidas em lugares diversos, isso não terá o condão de alterar o local da prestação 
dos serviços, que será, só e unicamente, aquele em que situado o estabelecimento escolhido para ultimação, perfazimento ou conclusão do serviço. ${ }^{740}$

No entanto, os laboratórios clínicos não são hoje "simples postos de atendimento", como considerou a decisão supramencionada. A diversidade e complexidade atual dos exames laboratoriais não admitem que os procedimentos sejam singelamente reduzidos a duas etapas, analogamente àquilo que ocorre nos procedimentos menos complexos, como um hemograma.

Ademais, não se pode esquecer que a Constituição Federal distribuiu a seus entes as competências tributárias como forma de obtenção de receitas, que são destinadas a suportar as despesas inerentes aos serviços a eles atribuídos pelo mesmo diploma legal.

Neste compasso, seria justo que se considerasse na análise relativa à percussão tributária, o impacto e o desembolso havido por cada um dos Municípios relativamente a tais atividades.

Vale dizer: o Município em que se localizam as sedes de tais laboratórios deve disponibilizar e manter, tanto para os usuários como a seus funcionários, transporte coletivo, rede viária, sinalização, limpeza urbana e vários outros serviços, cuja demanda é potencializada pela presença destes estabelecimentos. Por outro lado, as análises realizadas pelo servidor de dados, na maior parte de maneira autônoma, não demandarão do poder público serviços nem infraestrutura suplementar.

A solução da problemática relativa à definição do local onde ocorre a prestação dos serviços de análises clínicas dos laboratórios, cujas atividades são cindidas, com a utilização de equipamentos eletrônicos, consiste na configuração, ou não, deste servidor em estabelecimento prestador de serviços.

Conforme as conclusões alcançadas neste trabalho, a análise da configuração de um estabelecimento pelo servidor de dados deve considerar se as funções desempenhadas pelo equipamento são meramente complementares, ou se constituem as atividades principais da empresa. Desta forma, a solução será necessariamente casuística, devendo ser cotejadas as atividades desenvolvidas pelo servidor de dados àquelas exercidas no estabelecimento físico, consistente na recepção dos clientes, coleta dos materiais, procedimentos de imagem e ultrassom, entre outros. 


\subsubsection{Telemedicina}

As modernas tecnologias da informação e da comunicação propiciaram o surgimento da "telemedicina", um ramo da medicina exercido à distância com o auxílio das mencionadas tecnologias, que "possibilita cuidados à saúde nas situações em que a distância é um fator crítico", contribuindo para ampliar a abrangência de atendimento. Segundo o professor de telemedicina da USP, Chao Lung Wen, o desenvolvimento da infraestrutura para videoconferência e a implantação das redes de banda larga tornam a interatividade em tempo real, também nesta área, cada vez mais comum e factível. ${ }^{741}$

O Ministério da Saúde vem adotando, desde 2004, diversas ações no sentido de viabilizar a difusão e aplicação da matéria. ${ }^{742}$

Com a utilização destas tecnologias, possibilita-se a realização de certos procedimentos em locais remotos, evitando que ocorra o deslocamento físico do paciente. Segundo o Conselho Brasileiro de Telemedicina e Telessaúde, a telemedicina possui hoje os seguintes ramos: "(i) teleconsulta, que é o processo pelo qual se realiza uma consulta médica à distância. Para isso, pode ser empregado qualquer meio tecnológico que transporte som, imagem ou comunicação escrita. O conceito essencial é que não há contato presencial entre quem faz o ato médico e quem o recebe; (ii) teleconferência - no contexto da telemedicina, o termo designa uma busca de esclarecimento diagnóstico ou orientação terapêutica (uma segunda opinião) pelo médico e seu paciente, de um profissional ou instituição mais experiente, só alcançável por telecomunicação; (iii) televigilância acompanhamento de um paciente à distância por um profissional de saúde (por exemplo, médico ou enfermeira) ou instituição hospitalar. É o caso de doentes crônicos que foram atendidos pelo sistema de saúde e convalescem em suas residências. A situação mais frequente é a monitoração intra-hospitalar dos pacientes (por exemplo, comunicação entre

741 Cf. WEN, Chao Lung, Telemedicina e Telesaúde - Um Panorama no Brasil, Disponível em: <http://www.ip.pbh.gov.br/ANO10_N2_PDF/telemedicina telesaude.pdf >. Acesso em 15 de abril de 2011.

${ }^{742}$ Em dezembro de 2005, por solicitação do Ministério da Saúde (DEGES/SGTES), teve início o Projeto de Telemática e Telemedicina em apoio à Atenção Primária no Brasil. "Foram formados nove Núcleos (quatro foram instituições integrantes do Projeto de Telemedicina do Milênio - USP, UFMG, UEA e HCPA/UFRGS) para a implantação de 900 pontos de atenção primária, nos quais foram aplicados diversos aspectos acadêmicos e tecnológicos do Projeto de Telemedicina 'Estação Digital Médica'”. Em 2006, foi constituída a Comissão Permanente de Telessaúde e do Comitê Executivo de Telessaúde. Disponível em: <http://www.ip.pbh.gov.br/ANO10_N2_PDF/telemedicina_telesaude.pdf>. Acesso em 2 de julho de 2011. 
quartos ou unidades intensivas e o posto de enfermagem); e (iv) teleassistência, que consiste em prestar auxílio médico a um doente distante". ${ }^{743}$

Neste sentido, desde 2003, já são uma realidade os "ciberambulatórios" que informam o público por meio do site sobre câncer de pele e realizam a "avaliação dermatológica virtual". Com as orientações disponibilizadas no website, o interessado pode enviar alguns dados e fotos de suas lesões, recebendo a avaliação feita por um grupo de dermatologistas da Faculdade de Medicina da USP. ${ }^{744}$

Atualmente, o ramo que mais se utiliza dos meios virtuais é aquele voltado aos laudos. Realizam-se nesta modalidade, de maneira remota, a análise de exames de imagem como mamografia e tomografia, análise de fotos de lâminas de biopsias, de lesões de pele, eletrocardiogramas. Tudo via Internet, videoconferência ou radiodifusão, que permitem disponibilizar as imagens obtidas em qualquer lugar do mundo a profissionais especializados neste tipo de análise e que, após a elaboração do laudo, o retransmitem para o local em que o paciente está sendo tratado.

A rede pública de saúde do Estado de São Paulo está utilizando um sistema pioneiro na América Latina com o emprego destas tecnologias. Foi instalada na cidade de São Paulo uma central que elabora laudos para os exames de imagens realizados em hospitais, ambulatórios e centros de saúde de todo o Estado. São cinquenta profissionais que se revezam 24 horas por dia e expedem os resultados, em média, em trinta minutos, retransmitindo-os ao local de origem da imagem.

A incorporação da tecnologia à saúde alterou o paradigma do atendimento, evitando que Municípios menores e sem infraestrutura desloquem seus pacientes para serem submetidos às análises nos grandes centros, podendo contar com laudos especializados em menos de uma hora, no local da consulta, transmitidos por meios telemáticos.

$\mathrm{Na}$ Índia, estes centros de análises, aproveitando-se das diferenças de fuso horário, além de seu funcionamento normal durante o dia, prestam serviços durante a noite para consultórios, clínicas e hospitais nos Estados Unidos, otimizando os recursos técnicos. Neste caso, poderia estar se falando em exportação e importação de serviços.

\footnotetext{
743 Cf. Conselho Brasileiro de Telemedicina e Telessaúde. Disponível em: <http://www.cbtms.org.br/departamento/telemedicina/default.aspx >. Acesso em 2 de julho de 2011. ${ }^{744}$ Idem. Acesso em 2 de julho de 2011.
} 
A tecnologia permite também que se incorpore hoje, no curso de consultas médicas, uma segunda opinião especializada de profissionais à distância que atuam em outros centros médicos. A utilização de um robô guiado à distância por um cirurgião em um procedimento que ocorre em qualquer lugar do país, ou mesmo a incorporação de uma equipe médica de excelência para auxiliar a equipe local na execução das etapas mais complicadas de um procedimento cirúrgico já é uma realidade.

Da mesma forma, o acompanhamento eletrônico de pacientes crônicos, idosos ou convalescentes evita as frequentes visitas ao hospital, já que os dados referentes à pressão arterial, glicemia e batimentos cardíacos transmitidos via Bluetooth são monitorados pelo celular ou pelo computador do médico.

Considerando-se que os serviços médicos estão expressamente dispostos na Lista de Serviços anexa à Lei Complementar, surge a necessidade de perquirir aonde devem ser considerados prestados os serviços com a utilização dos recursos tecnológicos.

Dentre os casos apresentados analisaremos a modalidade mais utilizada, os serviços de telemedicina voltados aos laudos médicos de exames de imagem. Neste modelo de realização de análises de exames de imagem, a atividade desdobra-se, concentrando em um centro de imagem os patologistas responsáveis pela avaliação das imagens, que provêm de qualquer lugar do território brasileiro, ou mesmo estrangeiro, sendo extraídas e enviadas por meios telemáticos para análise.

A Lei Complementar $n^{\circ} 116 / 03$ prevê no item 4.02 da Lista Anexa os serviços de "análises clínicas, patologia, eletricidade médica, radioterapia, quimioterapia, ultrassonografia, ressonância magnética, radiologia, tomografia e congêneres”. Como não constitui uma das exceções ali elencadas, estes serviços estão submetidos à regra geral relativa ao critério espacial, sendo devido o Imposto sobre Serviços no local do estabelecimento prestador.

O conceito de estabelecimento prestador auxilia na elucidação da questão, definindo onde é devido o imposto. Nos termos do conceito disposto no art. $4^{\circ}$ da LC 116/03, o estabelecimento prestador é o local onde se desenvolve a atividade de prestar serviços.

Deve-se ressaltar que é imprescindível à configuração do conceito de “estabelecimento prestador" os elementos subjetivo e objetivo, definidos no item 5.12.3 deste estudo. 
No caso dos exames de imagem, temos dois locais possíveis para configurar o estabelecimento prestador de serviços: (i) aquele onde ocorre a análise das imagens e a emissão dos laudos e (ii) os locais onde são obtidas as imagens que embasam os respectivos laudos e que constituem o objeto da análise.

Note-se que a execução do serviço, que consiste na análise de imagens, ocorre efetivamente no centro de imagem onde são emitidos os laudos, podendo a atividade de captação de imagens ser considerada como meramente preparatória ou auxiliar, conforme os conceitos analisados da Convenção Modelo da OCDE, relativas ao “estabelecimento permanente".

Os mencionados conceitos equivalem aos conceitos elaborados pela doutrina nacional de "atividade-meio/atividade-fim", abordados neste estudo.

\subsubsection{Ensino à Distância}

Vimos que os serviços eletrônicos também estão presentes no segmento educacional, atingindo um número cada vez maior de usuários atraídos pela comodidade, flexibilidade de horário, facilidade de acesso à Internet e economia de tempo em eventuais deslocamentos. Já comentamos que, nos últimos dez anos, o número de matrículas saltou de 5 mil para 930 mil, concentradas nas áreas da educação, ciências sociais e direito.

Estas operações, por determinação do Ministério da Educação e da Cultura, não prescindem de uma base física para a realização das avaliações e outras atividades presenciais obrigatórias, como a sede da instituição ou polos de apoio presencial.

As aulas dos cursos administrados aos alunos podem ocorrer "ao vivo" em determinado local, com transmissão simultânea por satélite/Internet para diversos locais ou podem ser gravadas e retransmitidas posteriormente.

As aulas gravadas podem ser retransmitidas por vias digitais aos computadores domésticos dos alunos ou aos polos de apoio presencial da instituição, que possuem uma estrutura física, ainda que mínima, para disponibilização das gravações aos alunos, ou mesmo das aulas ao vivo transmitidas por satélite/Internet.

Nas situações analisadas, é possível considerar que as aulas foram ministradas no local onde ocorre a gravação da aula, nos polos de apoio que recebem as aulas ou ainda no local onde se encontra cada dispositivo que recepciona a transmissão. 
Considerar o local onde se localizam os alunos significa adotar como elemento de conexão o local onde está sendo produzida a utilidade dos serviços, que corresponde à fonte de rendimentos que, como vimos, encontra grande prestígio no campo internacional, mas exigiria uma alteração da legislação nacional para a adoção do mencionado critério.

Considerando as normas vigentes, impõe-se o elemento de conexão do "estabelecimento prestador", cabendo às instituições de ensino a avaliação de suas instalações e a definição de qual delas guarda pertinência ao conceito contido na Lei Complementar $n^{\circ} 116 / 03$, em que se configuram os elementos suficientes a possibilitar a percussão tributária. 


\section{CONCLUSÕES:}

Todas as considerações tecidas neste trabalho permitem chegar às seguintes conclusões a respeito do tema da tributação do ISS no comércio eletrônico:

1. Com base nos estudos desenvolvidos, propomos a seguinte estrutura de situações possíveis, ínsitas ao comércio eletrônico, a partir das quais tecemos nossas conclusões:

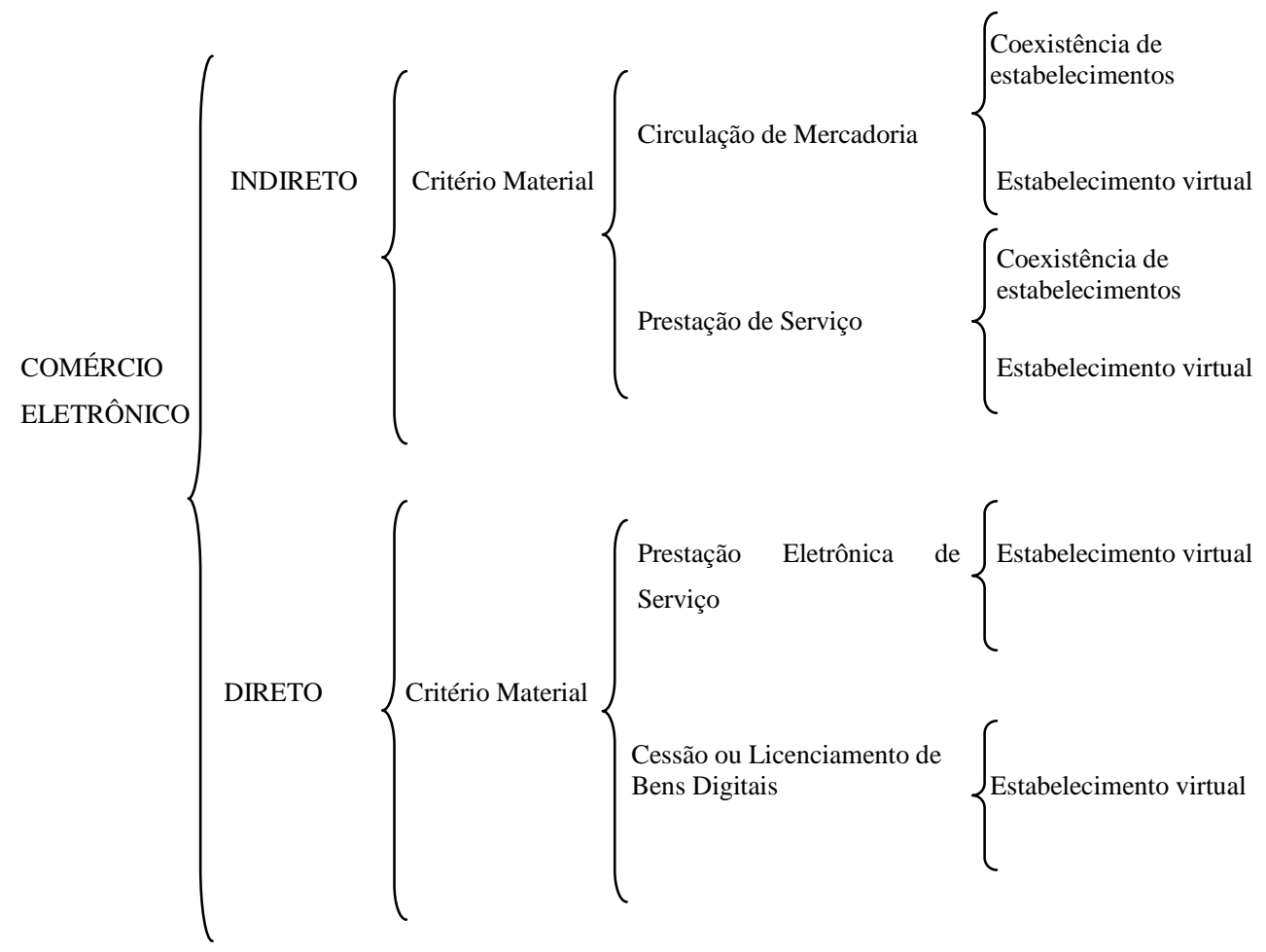

2. Há perfeita subsunção dos fatos jurídicos subjacentes às transações do comércio eletrônico indireto aos critérios materiais das normas gerais e abstratas dos impostos incidentes sobre o consumo. Tratando-se de compra e venda de mercadoria, incidirá, nos termos do art. 155, II da Constituição Federal, o ICMS; caso trate-se da prestação de serviços não abrangidos no art. 155, II, incidirá sobre tais operações, nos termos do art. 156, III da Carta Magna, o Imposto sobre Serviços de Qualquer Natureza.

2.1. A alteração na forma de contratação é a única repercussão nos fatos jurídicos "realizar operação mercantil" e "prestar serviço" no comércio eletrônico indireto. 
3. Na denominada "prestação eletrônica de serviços", não ocorre qualquer perturbação no critério material da regra-matriz do imposto sobre serviços, já que a utilização de meios telemáticos no desenvolvimento do trabalho e a tradição do produto final no formato de um arquivo digital não modificam o fato jurídico de prestar serviço.

4. Não incide o ICMS sobre a cessão de uso, ou outros modos de fruição dos bens digitais, objeto do comércio eletrônico direto.

5. Admitindo-se a visão que considera como foco na tributação a "utilidade", a ser obtida com a atividade e não com a atividade em si, é possível entrevermos prestações de serviço nas operações de cessão de direito e licenciamento de uso de bens digitais. Portanto, a noção de prestação de serviço passa a ser entendida como um fornecimento de utilidades, ainda que imateriais, abarcando, desta forma, os bens digitais.

5.1. Atualmente, a Lei Complementar $n^{\circ} 116 / 2003$ reflete em parte essa visão, definindo que os contratos de licença de uso, de cessão de direitos de uso de programas de computador e outros que propiciam o fluxo dos bens digitais, assim como as atividades de agenciamento, corretagem ou intermediação de direitos de propriedade industrial, artística ou literária a elas relacionadas, estão sujeitos à incidência do ISS.

6. A tributação diferenciada dos bens em função de sua forma, arquivo digital (ISS) ou mídia física (ICMS), constitui uma violação ao Princípio da Neutralidade, que orienta as operações do comércio eletrônico internacional, garantindo que tais operações não sejam tributadas de maneira mais gravosa, nem mais favorável do que aquelas realizadas pela forma tradicional de comércio.

7. As modalidades de disponibilização de recursos de TI do cloud computing, que envolvem uma grande estrutura de gerenciamento e controle dedicada ao fornecimento destas utilidades, constituem-se em prestações de serviços, sobre as quais incide o imposto de competência municipal. 
8. O elemento de conexão "local do estabelecimento prestador" não é o mais adequado para a definição da competência tributária sobre os serviços prestados por meios eletrônicos na forma direta.

8.1. O elemento de conexão mais adequado para compor o critério espacial das transações do comércio eletrônico, em especial na modalidade direta, é aquele da fonte dos rendimentos, que considera o local onde os serviços produzem seus resultados e onde estão situados os tomadores dos serviços para a definição da competência impositiva.

8.2. A tributação na fonte exige dos Fiscos mecanismos de controle para atribuir-lhe efetividade. Seria um destes mecanismos a instituição de um dever instrumental às empresas envolvidas na remuneração das operações do comércio eletrônico, consistente na declaração mensal de todos os valores repassados aos fornecedores de bens e serviços envolvidos em transações eletrônicas.

9. Os servidores de dados, assim como as web pages, podem configurar um estabelecimento para fins de atribuição do direito subjetivo de tributar os rendimentos das operações do "comércio eletrônico" quando atendam concomitantemente aos seguintes requisitos: (i) estar afixados em determinado território, por um período de tempo suficiente; (ii) as atividades da empresa sejam total ou prioritariamente desenvolvidas no equipamento; (iii) que as atividades desenvolvidas no servidor não se configurem como preparatórias ou auxiliares, sendo dispensável a presença de representantes ou agentes da empresa operando o equipamento.

10. A web page por meio da qual se desenvolvem as operações de comércio eletrônico pode ser considerada um estabelecimento prestador de serviços quando instalada em um servidor de dados próprio, locado ou recebido em comodato, operado por pessoal próprio, física ou remotamente, e desde que permaneça o equipamento por um período superior a 183 dias, para que seja considerado fixo.

10.1. No caso das empresas que atuam no mercado exclusivamente por meio de web pages, o estabelecimento se configura naquele endereço físico declarado pelo titular do domínio e vinculado ao CNPJ da empresa para o registro do site. 


\section{REFERÊNCIAS BIBLIOGRÁFICAS}

ALBERTIN, Alberto Luiz. Comércio Eletrônico - Modelos, Aspectos e Contribuições de sua aplicação. $6^{\text {a }}$ ed. São Paulo: Editora Atlas.

AMARO, Luciano. Direito Tributário Brasileiro. 13ª ed. São Paulo: Editora Saraiva, 2007.

ANDRADE, José Maria Arruda de. Interpretação da Norma Tributária. São Paulo: MP Editora, 2006.

ATALIBA, Geraldo. Hipótese de Incidência Tributária. $2^{\mathrm{a}}$ ed. São Paulo: Editora Revista dos Tribunais Ltda., 1978.

. Sistema Constitucional Tributário Brasileiro, São Paulo: Revista dos Tribunais, 1968.

ÁVILA, Humberto. Imposto sobre a Prestação de Serviços de Qualquer Natureza. Exportação de Serviços. Lei Complementar no 116/2003. Isenção: Requisitos e Alcance. Conceitos de "Desenvolvimento" de Serviço e "Verificação" de seu resultado. Revista Dialética de Direito Tributário. São Paulo: Dialética, nº. 134, pp. 101/109.

Imposto sobre a Prestação de Serviços de Qualquer Natureza, Contrato de Leasing Financeiro. Decisão do Supremo Tribunal Federal. Local da Prestação e Base de Cálculo. Revista Dialética de Direito Tributário. São Paulo: Dialética, no. 182, pp. 133/144.

ARAUJO, Clarice Von Oertzen. Semiótica do Direito. São Paulo: Quartier Latin, 2005.

AVY-YONAH, Reuven S. United States, International - Back to the Future? The Potential Revival of Territoriality. Bulletin for International Taxation, IBFD. Vol. 62, 2008.

BALEEIRO, Aliomar. Direito Tributário Brasileiro. 10a ed. Rio de Janeiro: Companhia Editora Forense, 1984.

BAPTISTA, Marcelo Caron. ISS do texto à norma - Doutrina e Jurisprudência da EC 18/65 à LC 116/03. São Paulo: Quartier Latin, 2005. 
BARRETO, Aires Fernandino. ISS na Constituição e na Lei. $3^{\text {a }}$ ed. São Paulo: Dialética, 2009.

Curso de Direito Tributário Municipal. São Paulo: Saraiva, 2010.

ISS - Não incidência sobre Cessão de Espaço em Bem Imóvel, Apud MELO, José Eduardo S. e PAULSEN, Leandro, Impostos Federais, Estaduais e Municipais, Livraria do Advogado, Porto Alegre, 2007.

- ISS - Organização e Execução de Pacotes Turísticos, inclusive de Viagens Marítimas Temáticas - Local da Prestação dos Serviços - Navios podem ser Considerados como "Estabelecimento Prestador" para Fins de Incidência Tributária - Base de Cálculo dos Serviços de Organização e Execução de Pacotes Turísticos. Revista Dialética de Direito Tributário. São Paulo: Dialética, nº 165, pp. 117/133.

BARRETO, Paulo Ayres. Elisão Tributária - Limites Normativos. São Paulo: USP, 2008.

Contribuições: Regime Jurídico, Destinação e Controle, São Paulo, Noeses, 2006.

BELLAN, Daniel Vitor. Interpretação dos Tratados Internacionais em Matéria Tributária. In TORRES, Heleno (coord.), Direito Tributário Internacional. São Paulo: Quartier Latin, 2005. Volume III, pp. 646-653.

Comércio Eletrônico e Responsabilidade Tributária das Administradoras de Cartão de Crédito. In Internet - O Direito na Era Virtual. SCHOUERI, Luis Eduardo, organizador. 2a . ed. Rio de Janeiro: Forense, 2001.

BORGES, José Souto Maior. Lei Complementar Tributária. São Paulo: Editora da Universidade Católica, 1975.

BUENO, Silveira. Grande Dicionário Etimológico-prosódico da Língua Portuguesa. São Paulo: Edição Saraiva, 1964. $2^{\circ}$ volume.

BRAGHETTA, Daniela de Andrade. Tributação no Comércio Eletrônico à luz da Teoria Comunicacional do Direito. São Paulo: Quartier Latin, 2003.

BRAVERMAN. Harry. Trabalho e Capital Monopolista - a Degradação do Trabalho no Século XX. $3^{\mathrm{a}}$. ed. Rio de Janeiro: Editora Guanabara.

CAMBRIDGE Advanced Learner's Dictionary. Cambridge University Press, New York, 2008. 
CAMPOS, Diogo Leite de e CAMPOS, Monica Horta Neves, Direito Tributário, 2 ${ }^{\mathrm{a}}$. ed., Coimbra, Del Rey, Portugal, 2001.

CARVAlHo, Aurora Tomazini de. Curso de Teoria Geral do Direito: o Construtivismo Lógico-Semântico. São Paulo: Noeses, 2009.

CARVAlHo, Paulo de Barros. Direito Tributário - Fundamentos Jurídicos da Incidência. São Paulo: Saraiva. $2^{a}$ edição, 1999.

Curso de Direito Tributário. São Paulo, Saraiva, 19ª ed., 2007.

Direito Tributário - Linguagem e Método. São Paulo: Noeses, $1^{\text {a }}$ ed., 2008.

CARRAZZA, Roque Antonio. Curso de Direito Constitucional Tributário. 24a. ed., São Paulo: Malheiros, 2008.

CEZAROTI, Guilherme. ICMS no Comércio Eletrônico. São Paulo: MP Editora, 2005.

COELHO, Sacha Calmon Navarro e DERZI, Misabel Abreu Machado. O Aspecto Espacial da Regra-matriz do Imposto Municipal Sobre Serviços, à Luz da Constituição. In Revista Dialética de Direito Tributário n 88. São Paulo: Dialética. 2003.

COELHO, Fábio de Ulhoa. Curso de Direito Comercial. v. 3. $4^{\mathrm{a}}$ ed. rev., atual. São Paulo: Saraiva, 2003.

Curso de Direito Comercial. v. 1.4a . ed. rev., atual. e ampl. São Paulo: Saraiva, 2000.

CONTI, José Maurício, Federalismo fiscal e fundos de participação, São Paulo, Juarez de Oliveira, 2001.

COPI, Irving Marmer. Introdução à Lógica. Tradução de Álvaro Cabral. $2^{\mathrm{a}}$ ed., São Paulo: Mestre Jou, 1978.

CRETELLA NETO, José. Do Contrato Internacional de Franchising. Rio de Janeiro: Forense, 2000.

DERZI, Mizabel de Abreu. Direito Tributário, Direito Penal e Tipo. $2^{\mathrm{a}}$ ed. ver. e atual. São Paulo: Ed. Revista dos Tribunais, 2007.

DINIZ, Maria Helena. Código Civil Anotado. 9ª . ed.. São Paulo: Saraiva, 2003.

DOERNBERG, Richard L., Eletronic Commerce and International Tax Sharing. Tax Notes International, Março de 1998. 
EMERENCIANO, Adelmo da Silva. Tributação no Comércio Eletrônico. Coleção de Estudos Tributários, Paulo de Barros Carvalho coordenador, Síntese e Thomson IOB. São Paulo: 2003.

FERNANDES, Cintia Estefania. IPTU - Texto e Contexto. São Paulo: Quartier Latin, 2005.

FERRAZ JUNIOR, Tercio Sampaio. Introdução ao Estudo do Direito. 6 ${ }^{\mathrm{a}}$. ed. São Paulo: Editora Atlas S.A., 2008.

Livro Eletrônico e Imunidade Tributária. Revista dos Tribunais - Cadernos de Tributário e Finanças Públicas. São Paulo: Revista dos Tribunais $n^{\circ} 22$, janeiromarço de 1998.

Direito Constitucional, - Liberdade de Fumar, Privacidade, Estado, Direitos Humanos e Outros Temas. São Paulo: Manole, 2007, pp. 337 - 371.

FLUSSER, Vilém. Lingua e Realidade. 3ª ed..São Paulo: Annablume, 2007.

FURLAN, Valéria. Imposto Predial e Territorial Urbano. São Paulo: Malheiros, 2004.

GAMA, Tácio Lacerda. Contribuição de Intervenção no Domínio Econômico, São Paulo, Quartier Latin, 2003.

Competência Tributária - Fundamentos para uma Teoria da Nulidade. São Paulo: Noeses, 2009.

GAZZO, Massimiliano. Permanent Establishment Through Related Corporations in Bulletin for International Taxation. IBFD, Junho/2003.

GRAU, Eros Roberto. O Direito Posto e o Direito Pressuposto. $7^{\text {a }}$ ed. São Paulo: Malheiros, 2008.

GRECO, Marco Aurélio. Estabelecimento Tributário e Sites na Internet. In LUCCA, Newton De e SIMÃO FILHO, Adalberto (coord.), Direito \& Internet - Aspectos Jurídicos Relevantes. São Paulo: Quartier Latin, $2^{\mathrm{a}}$ ed., 2005. Internet e o Direito. $2^{\text {a }}$ ed. revista e aumentada. São Paulo: Dialética, 2000.

HOFFMANN, Suzy Gomes. A Competência dos Municípios para a Instituição e Cobrança do ISSQN e a Responsabilidade Tributária do Tomador de Serviços no Pagamento 
do ISSQN. Revista Dialética de Direito Tributário. São Paulo: Dialética, nº 105, pp. 83/94.

HORTA, Raul Machado. Direito Constitucional, $3^{\mathrm{a}}$.ed. rev., atual. e ampl., Belo Horizonte: Del Rey, 2002.

LEONARDOS, Gabriel Francisco. Tributação da Transferência de Tecnologia. Rio de Janeiro: Forense, 1997.

LÉVY, Pierre. As Tecnologias da Inteligência: o futuro do pensamento na era da Informática. Tradução de Les Technologies de L'Intelligence de Carlos Irineu da Costa. Rio de Janeiro: Ed. 34, 1993.

O que é o Virtual? Tradução de Qu'est-ce que Le Virtuel? de Paulo Neves. Rio de Janeiro: Ed. 34, 1996.

Cibercultura. Tradução de Cyberculture de Carlos Irineu da Costa. Rio de Janeiro: Ed. 34,1999.

LOPES, Miguel Maria de Serpa. Curso de Direito Civil. v. 3. Rio de Janeiro: Freitas Bastos, 1991.

LUCCA, Newton. Direito \& Internet. São Paulo: Quartier Latin. $2^{\mathrm{a}}$ edição.

MACEDO, Alberto, ISS e IPI - A Lei Complementar e o Redesenho das Fronteiras Competenciais, In: Paulo de Barros Carvalho; Priscila de Souza. (Org.). VI Congresso Nacional de Estudos Tributários - Sist. Tributário Brasileiro e a Crise Atual. 1 ed. São Paulo: Noeses, 2009, v. VI, p. 1-21.

MACHADO, Raul Horta. Direito Constitucional. $3^{\mathrm{a}}$ ed. rev., atual. e ampl.. Belo Horizonte: Del Rey, 2002.

MARTINS, Ricardo Lacaz e RABELLO, Carolina M. Motta. Algumas Considerações a Respeito dos Contratos de Nível de Serviços - SLAs. In Internet - O Direito na Era Virtual. SCHOUERI, Luis Eduardo, organizador. 2a . ed. Rio de Janeiro: Forense, 2001.

MEIRELLES, Hely Lopes, Direito Municipal Brasileiro, $15^{\mathrm{a}}$ ed. atual., São Paulo, Malheiros, 2007.

MELO, José Eduardo Soares de. Curso de Direito Tributário. $7^{\mathrm{a}}$ ed. São Paulo: Dialética, 2007. 
ICMS - Teoria e Prática. 9a ed. São Paulo: Dialética, 2006.

e PAULSEN, Leandro. Impostos Federais, Estaduais e Municipais. $3^{\mathrm{a}}$ ed. Porto Alegre: Livraria do Advogado, 2007.

MONTEIRO, Washigton de Barros. Atualizada por Carlos Alberto Dabus Maluf. Curso de Direito Civil - Direito das Obrigações, $1^{a}$. Parte. 32ª . ed. São Paulo: Saraiva, 2003.

MORAES, Bernardo Ribeiro de. Doutrina e Prática do Imposto sobre Serviços. $1^{\mathrm{a}}$ ed, $3^{\mathrm{a}}$ tiragem. São Paulo: Ed. Revista dos Tribunais, 1984.

MOUSSALLEM, Tárek Moysés. Fontes do Direito Tributário. São Paulo: Editora Max Limonad.

OLIVEIRA, José Marcos Domingues. Imposto sobre Serviços e Fato Gerador - o Local da Prestação de Serviços. Revista Dialética de Direito Tributário. São Paulo: Dialética, nº 105, pp. 69/77.

OLIVEIRA, Júlio Maria de. Internet e Competência Tributária. São Paulo: Dialética, 2001.

PEREIRA, Caio Mário da Silva. Instituições de Direito Civil - Volume 1. $20^{\mathrm{a}}$ ed.. Rio de Janeiro: Forense, 2004.

PINHO, Diva Benevides, Aspectos da Evolução da Ciência Econômica - da Economia da Informação às raízes do pensamento econômico, in Manual de Economia, Amaury Patrick Gremaud...[et al]; org. Diva Benevides Pinho e Marco Antonio S. Vasconcelos, $5^{\text {a }}$ ed.. São Paulo: Saraiva, 2004.

PINTO, Dale. E-Commerce and Source-based Income Taxation. Amsterdam: IBFD, Doctoral Series, v.6, 2003.

POLI, Leonardo Macedo. Direitos de Autor e Software. Belo Horizonte: Del Rey, 2003. Direito Autoral - Parte Geral. Belo Horizonte: Del Rey, 2008.

RODRIGUES, Silvio. Direito Civil. Volume 2. São Paulo: Saraiva, 30a. ed., 2002. Direito Civil. Volume 1. São Paulo: Saraiva, 33a. ed. atualizada, 2003. 
ROLIM, Gerson; GONZALEZ, Leandro. Evolução do Comércio Eletrônico no MERCOSUL. In Emerging Markets Conference, Novembro 2012. ACERVO PROJETO MERCOSUL DIGITAL, São Paulo.

SANTAELLA, Lúcia. O que é Semiótica. 32a . Reimpressão da $1^{\text {a }}$. ed. de 1983. São Paulo: Braziliense. 2012

SANTI, Eurico Marcos Diniz de. Lançamento Tributário. 2a ed. São Paulo: Max Limonad, 2001.

- O Código Tributário Nacional e as normas gerais de Direito Tributário. In Curso de Direito Tributário e Finanças Públicas - do fato à norma, da realidade ao conceito jurídico. SANTI, Eurico Marcos Diniz, (Coordenador). São Paulo: Saraiva, 2008.

ISS versus ICMS na Prestação de Serviços. Revista Dialética de Direito Tributário. São Paulo: Dialética, nº. 186, pp. 23/29.

SANTOS, Manoel J. Pereira. O Direito Autoral na Internet. In Direito e Internet - Relações Jurídicas na Sociedade Informatizada. Marco Aurelio Greco e Ives Gandra da Silva Martins (coords.). São Paulo: Revista dos Tribunais, 2001.

SCHOUERI, Luis Eduardo, Discriminação de Competências e Competência Residual. In: Direito Tributário: Estudos em Homenagem a Brandão Machado, São Paulo, Dialética, 1998.

. Tributação e Cooperação Internacional in Revista Fórum de Direito Tributário, $\mathrm{n}^{\mathrm{o}} 7$, Belo Horizonte, Fórum, 2004, pp.25-54.

Normas Indutoras e Intervenção Econômica. São Paulo: Forense. 2005. pp. 231-266.

Imposto de Renda e o Comércio Eletrônico. In Internet - O Direito na Era Virtual. SCHOUERI, Luis Eduardo, organizador. $2^{\mathrm{a}}$. ed. Rio de Janeiro: Forense, 2001.

Princípios no Direito Tributário Internacional: Territorialidade, Fonte e Universalidade. In Princípios e Limites da Tributação. FERRAZ, Roberto, coordenador. São Paulo: Quartier Latin, 2005.

SILVA, Emerson Drigo da. Aspecto Espacial da Incidência do ISS Sobre os Serviços Prestados via Internet. In Internet - O Direito na Era Virtual. SCHOUERI, Luis Eduardo, organizador. $2^{\mathrm{a}}$. ed. Rio de Janeiro: Forense, 2001.

- Aspecto Espacial da Tributação dos Serviços Prestados por meio da Internet. São Paulo: USP. 2004. 
TÔRRES, Heleno Taveira. Pluritributação Internacional sobre as Rendas de Empresas. São Paulo: Revista dos Tribunais, 2001.

UCKMAR, Victor. Tributação do Comércio Eletrônico. Atualidades e Perspectivas. Tradução de Marco Aurélio Greco. In Direito e Internet - Relações Jurídicas na Sociedade Informatizada. Marco Aurelio Greco e Ives Gandra da Silva Martins (coords.). São Paulo: Revista dos Tribunais, 2001.

VALADÃO, Marcos A.P. Uma visão ampliada dos efeitos da globalização no sistema tributário brasileiro, in Revista de Direito Tributário Internacional, ano $4, \mathrm{n}^{\circ} 11$, 2009, pp. 131-169.

VASCONCELLOS, Roberto de França. Tributação do comércio eletrônico internacional. São Paulo: USP, 2002.

VASCONCELLOS, Marco Antonio Sandoval. Sistemas de Contabilidade Social: contas nacionais no Brasil. In Manual de Economia, Amaury Patrick Gremaud...[et al]; org. Diva Benevides Pinho e Marco Antonio S. Vasconcelos. $5^{\text {a }}$ ed.. São Paulo: Saraiva, 2004.

VELLOSO, Andrei Pitten. Conceitos e Competências Tributárias. São Paulo: Dialética, 2005.

VERAS, Manoel. Cloud Computing: Nova Arquitetura de TI. Rio de Janeiro: Brasport Livros e Multimídia, 2012.

ZIMMERMANN, Augusto, Teoria Geral do Federalismo Democrático. 2a . ed. Rio de Janeiro: Lumen Juris, 2005.

XAVIER, Alberto. Direito Tributário Internacional do Brasil. Rio de Janeiro: Forense, 2002.

\section{REFERÊNCIAS ELETRÔNICAS}

ALCHOURRÓN, Carlos E.; BULYGIN, Eugenio. Introducción a la metodología de las ciencias jurídicas y sociales. Disponível em: <http://www.cervantesvirtual.com/servlet/SirveObras/45707392103492762565679 /p0000001.htm\#I_4>. 
ALECRIM, Emerson. $O$ que é Cloud Computing? Disponível em: $\langle$ http://www.infowester.com/cloudcomputing.php $>$.

ARANHA, Glaucio. O Processo de Consolidação dos Jogos Eletrônicos como Instrumento de Comunicação e de Construção de Conhecimento. Ciências \& Cognição 2004; Vol 03: 21-62 Disponível em: <http://www.cienciasecognicao.org/revista/index.php/cec/article/view/473>.

Publicado on-line em 31 de novembro de 2004.

BARROS, Fábio. Cloud Computing: prepare-se para a nova onda em tecnologia. Disponível em: $\quad<$ http://computerworld.uol.com.br/gestao/2008/04/17/cloud-computingprepare-se-para-a-nova-onda-em-tecnologia/>.

BREMAEKER, Francois E. J. As Receitas Tributárias Municipais. in http://www.oim.tmunicipal.org.br/abre_documento.cfm?arquivo=_repositorio/_oi $\mathrm{m} /$ documentos/772BEFF2-97EB-A456AC5D09788463BB7D04102010091629.PDF\&i=1215. 2010.

CAMPOS, Sarmento. Cronologia das Telecomunicações. Disponível em: <http://www.sarmento.eng.br/Telecomunicacoes.htm>. 2002.

CARTILHA DA REFORMA TRIBUTÁRIA. Disponível em: < http://www.fazenda.gov.br/portugues/documentos/2008/fevereiro/CartilhaReforma-Tributaria.pdf $>$. Fevereiro 2008.

CARVALHO, Marcelo Sávio Revoredo Menezes. A Trajetória da Internet no Brasil: do Surgimento das Redes de Computadores à Instituição dos Mecanismos de Governança. Dissertação - Universidade Federal do Rio de Janeiro. Disponível em: $\quad$ http://www.nethistory.info/Resources/Internet-BR-Dissertacao-MestradoMSavio-v1.2.pdf>. Setembro 2006.

CASTRO, Kleber Pacheco. Tributação do Setor de Petróleo: evolução e perspectivas. Disponível em: <http://www.esaf.fazenda.gov.br/esafsite/Biblioteca/arquivos/100616ESAFTributacaoPetroleo.pdf>.

CHEROBINO, Vinicius. SaaS: Quatro letras para conquistar as pequenas empresas. Revista Eletrônica Computerworld. Disponível em: <http://computerworld.uol.com.br/gestao/2007/10/16/idgnoticia.2007-10$15.3940692242 />$. Outubro 2007.

Clarification on the Application of the Permanent Establishment Definition in E-Commerce: Changes to the Commentary on The Model Tax Convention on Article 5. Disponível em: http://www.oecd.org/dataoecd/46/32/1923380.pdf. 
Congresso pode Taxar Nuvem, Disponível em: < http://convergenciadigital.uol.com.br/cgi/cgilua.exe/sys/start.htm?infoid=30888\&s $\underline{\mathrm{id}=97>}$.

CORREA, Rafael. A Era da Conectividade. Revista Veja Edição 2299. Disponível em: <http://veja.abril.com.br/acervodigital/home.aspx >. pp. 157-160. Dezembro 2012.

CUELLO, Rafael Oliver. Fiscalidad internacional y comercio electrónico. Revista de Internet, Derecho y Política $\mathrm{n}^{\circ}$ 9, Agosto de 2009. Universitat Oberta de Catalunya. Espanha. Disponível em: < HTTP://idp.uoc.edu/ojs/index.php/...oliver/289>.

EUA, The Departament of Tresury. Selected Tax Policy Implications Of Global Electronic Commerce. Disponível em: <http://www.treasury.gov/resource-center/taxpolicy/Documents/internet.pdf $>$. Novembro 1996.

FONSECA FILHO, Cléuzio. História da computação [recurso eletrônico]: O Caminho do Pensamento e da Tecnologia. Porto Alegre: EDIPUCRS, 2007. Disponível em: 〈http://www.pucrs.br/edipucrs/online/historiadacomputacao.pdf $>$.

GODOY, Alexandre de. An Overview of Some Legal Aspects of Eletronic Commerce in Brazil. International Trends and an Approach to the Brazilian Tax on Communication Services. Texto apresentado à Scholl Of Businnes and Public Management da Universidade George Washington, Washington D.C.: George Washington University, XIV Minerva Program Fall. 2001. Disponível em <.http://www.gwu.edu/ ibi/minerva/Fall2001/godoy.alexandre.pdf.>.

Herman Hollerith. History. U.S. Census Bureau. Disponível em: http://www.census.gov/history/www/census_then_now/notable_alumni/herman_h ollerith.html>.

História da RNP. Disponível em: 〈http://www.rnp.br/rnp/historico.html〉.

HOUAISS. Dicionário Eletrônico. Disponível em: 〈http://houaiss.uol.com.br/gramatica.jhtm>.

IDG-Now. e-Commerce, e-Business. e-O que? Disponível em http://www.ecommerce.org.br/artigos/ecommerce_ebusiness.php.

INFOWORLD/EUA. 11 Categorias de Cloud Computing. Revista Eletrônica Computerworld. Março 2010. Disponível em: 
$<$ http://computerworld.uol.com.br/tecnologia/2010/03/03/11-categorias-de-cloudcomputing/>.

LEE, Chang Hee, Impact of E-Commerce on Allocation of Tax Revenue Between Developed and Developing Countries, Journal of Korean Law, Vol. 4, No. 1, 2004. Disponível em <http://papers.ssrn.com/sol3/papers.cfm?abstract_id=658103>.

LEINER, Barry M, CERF, Vinton G., CLARK, David D., KAHN, Robert E., KLEINROCK, Leonard, LYNCH, Daniel C., POSTEL, Jon, ROBERTS, Larry G., WOLFF, Stephen. Brief History of the Internet. Disponível em: <http://www.internetsociety.org/internet/internet-51/history-internet/brief-historyinternet>.

LOEFF, Betsy. Cloud Computing: The Evolution of Software-as-a-Service. W.P. Carey School of Business at Arizona State University. Revista Eletrônica KnowWPC. Disponível em: <http://knowledge. wpcarey.asu.edu/article.cfm?articleid=1614 >.

MELL, Peter. GRANCE, Timothy. The NIST - National Institute of Standards Technology Definition of Cloud Computing. U.S. Departament of Commerce. Disponível em: <http://csrc.nist.gov/publications/nistpubs/800-145/SP800-145.pdf>. Setembro 2011.

MOREIRA, Daniela. Cloud Computing: entenda esse novo modelo de computação. Disponível em: <http://idgnow.uol.com.br/ti-corporativa/2008/08/13/cloudcomputing-entenda-este-novo-modelo-de-computacao/>.

NETO, Pedro Alcântara. História das Comunicações e das Telecomunicações. Disponível em: $<$ http://www2.ee.ufpe.br/codec/Historia\%20das\%20comunicaes\%20e\%20das\%20t elecomunicaes_UPE.pdf $>$.

NITAHARA, Akemi. Mesmo com a Crise Mundial, serviços prestados à família mantêm trajetória de crescimento. Agência Brasil. Disponível em: $<$ http://agenciabrasil.ebc.com.br/noticia/2012-09-26/mesmo-com-crise-mundialservicos-prestados-familia-mantem-trajetoria-de-crescimento\#.ULnsWHjIDE.mailto >. Setembro 2012.

NUNES, Paulo. Conceito de OPEX. Ciências Econômicas e Empresariais - Gestão. 2009. Disponível em: <http://www.knoow.net/cienceconempr/gestao/opex.htm>.

OCDE, Comentários da Convenção Modelo. Disponível em $<$ http://www.keepeek.com/Digital-Asset-Management/oecd/taxation/model-taxconvention-on-income-and-on-capital-2010_9789264175181-en 
Origem Evolução $\quad$ e $d a$ Internet. Disponível em:

$<$ http://profviseu.com/pessoal/formacao/hist.htmll $>$.

PC Magazine Encyclopedia. PCMAC.COM. Disponível em:

< HTTP://pcmag.com/encyclopedia_term/0,2542,t=plu-in $>$.

RONCOLATO, Maurício. O Futuro da Internet nas mãos dos governos em Dubai. O Estado de São Paulo $\quad-\quad$ Economia. Disponível em: <http://www.aasp.org.br/aasp/imprensa/clipping/cli_noticia.asp?idnot=13372 >. Novembro 2012.

SANTAELLA, Lúcia. Da Cultura das Mídias à Cibercultura: o Advento do Pós-Humano. Disponível em: $<$ http://revistaseletronicas.pucrs.br/ojs/index.php/revistafamecos/article/viewFile/3 $\underline{229 / 2493}$ >. Dezembro 2003.

SOARES, Edileuza. O Brasil se prepara para dar um salto em Cloud Computing. Revista Eletrônica CIO. Agosto 2012. Disponível em: <http://cio.uol.com.br/noticias/2012/08/09/brasil-se-prepara-para-dar-um-saltoem-cloud-computing/>.

STOBBE, Antje, Dawn of Technological Convergence. Deutsche Bank Research. Maio 2006. Disponível em: <http://www.dbresearch.com/PROD/DBR_INTERNET_ENPROD/PROD0000000000198220.pdf $>$.

The Little Data Book on Information and Communication Tecnology 2012. International Telecommunications Union - ITU. Disponível em: <http://www.itu.int/ITUD/ict/statistics/explorer/index.html>.

USP investe US\$ 200 milhões em projeto de cloud computing, Disponível em:< http://computerworld.uol.com.br/tecnologia/2012/09/24/usp-investe-us-200milhoes-em-projeto-de-cloud-computing $>$.

VERDI, Fábio Luciano. Cloud Computing, Data Centers e Governo: desafios $e$ oportunidades. Disponível em: 〈http://www.ppgccs.net/verdi/csbc_wcge10.pdf>. Julho 2010.

WEBSHOPPERS E-BIT, $26^{\circ}$ Relatório Semestral de Comportamento do Comércio Eletrônico no Brasil. Disponível em: 〈http://www.webshoppers.com.br/webshoppers/WebShoppers26.pdf>. Março 2012. 
WEN, Chao Lung. Telemedicina e Telessaúde - Um Panorama no Brasil. Disponível em: $<$ http://www.ip.pbh.gov.br/ANO10_N2_PDF/telemedicina telesaude.pdf $>$. Julho 2008.

WIKIPÉDIA. Disponível em: < http://pt.wikipedia.org/wiki/TCP/IP>. 